\title{
An Evaluation of Unthrottled Combustion System Options for Light Duty Applications with Future Syncrude Derived Fuels
}

December 1982

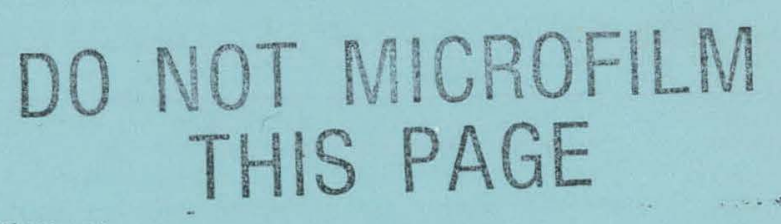

Prepared for:

The U.S. Department of Energy

Assistant Secretary for Conservation and Renewable Energy

Office of Vehicle and Engine $R$ \& $D$

Under Contract No. AC01-80CS50021 


\section{DISCLAIMER}

This report was prepared as an account of work sponsored by an agency of the United States Government. Neither the United States Government nor any agency Thereof, nor any of their employees, makes any warranty, express or implied, or assumes any legal liability or responsibility for the accuracy, completeness, or usefulness of any information, apparatus, product, or process disclosed, or represents that its use would not infringe privately owned rights. Reference herein to any specific commercial product, process, or service by trade name, trademark, manufacturer, or otherwise does not necessarily constitute or imply its endorsement, recommendation, or favoring by the United States Government or any agency thereof. The views and opinions of authors expressed herein do not necessarily state or reflect those of the United States Government or any agency thereof. 


\section{DISCLAIMER}

Portions of this document may be illegible in electronic image products. Images are produced from the best available original document. 


\section{DO NOT MICROFILM THIS PAGE}

\section{DISCLAIMER}

"This report was prepared as an account of work sponsored by an agency of the United States Government. Neither the United States Government nor any agency thereof, nor any of their employees, makes any warranty, express or implied, or assumes any legal liability or responsibility for the accuracy, completeness, or usefulness of any information, apparatus, product, or process disclosed, or represents that its use would not infringe privately owned rights. Reference herein to any specific commercial product, process, or service by trade name, trademark, manufacturer, or otherwise, does not necessarily constitute or imply its endorsement, recommendation, or favoring by the United States Government or any agency thereof. The views and opinions of authors expressed herein do not necessarily state or reflect those of the United States Government or any agency thereof."

This report has been reproduced directly from the best available copy.

Available from the National Technical Information Service, U. S. Department of Commerce, Springfield, Virginia 22161.

Price: Printed Copy A06

Microfiche A01

Contes are used for pricing all publications. The code is determined by the number of pages in the publication. Information pertaining to the pricing codes can be found in the current issues of the following publications, which are generally available in most libraries: Energy Research Abstracts, (ERA); Government Reports Announcements and Index (GRA and I); Scientific and Technical Abstract Reports (STAR); and publication, NTIS-PR-360 available from (NTIS) at the above address. 


\title{
An Evaluation of Unthrottled \\ Combustion System Options for Light Duty Applications with Future Syncrude Derived Fuels
}

\author{
DISCLAIMER
}

December 1982

Prepared by:

J. R. Needham

B. M. Cooper

S. R. Norris-Jones

Ricardo Consulting Engineers plc

Bridge Works, Shoreham-by-Sea

Sussex, BN4 5FG, England

Under Contract No. AC01-80CS50021

\begin{abstract}
This report was prepared as an account of work sponsored by an agency of the United States Government. Neither the United States Government nor any agency thereof, nor any of their employees, makes any warranty, express or implied, or assumes any legal liability or responsibility for the accuracy, completeness, or usefulness of any information, apparatus, product, or process disclosed, or represents that its use would not infringe privately owned rights. Reference herein to any specific commercial product, process, or service by trade name, trademark, manufacturer, or otherwise does not necessarily constitute or imply its endorsement, recommendation, or favoring by the United States Government or any agency thereof. The views and opinions of authors expressed herein do not necessarily state or reflect those of the United States Government or any agency thereur.
\end{abstract}

Prepared for:

The U.S. Department of Energy

Assistant Secretary for Conservation and Renewable Energy

Office of Vehicle and Engine R \& D

Washington, DC 20585

NOTICE

PORTIONS OF THIS REPORT ARE ILLEGIBLE.

It has been reproduced from the best avaitabio copy to permit the broadest possible availability. 
Demand upon finite petroleum crude reserves is forcing various countries to examine alternatives. In the USA, liquid hydrocarbon fuels manufactured from coal and oll shale are receiving much attention. When considering alternative fuels, the trade-offs between production costs, fuel specifications and technical implications in use must be reviewed. - ,

As part of such a trade-off study, this report details an experimental programme examining the interaction between several fuel and $11 \mathrm{ght}$ duty automotive engine combinations. Combustion systems addressed covered Indirect and direct injection diesel and spark Ignited stratified charge. Fuels primarily covered D2, naphtha and intermediate broadcut blends. Low ignition quality diesel fuels were also evaluated.

The results indicate the baseline fuel tolerance of each combustion system and enable characteristics of the systems to be compared. Performance, gaseous and particulate enissions aspects were assessed. The data obtalned assists in the selection of candidate combustion systems for potential future fuels. Performance and environmental penalties as appropriate are highlighted relative to che individual candidates. Areas of further work for increased understanding are also reviewed. 
Abstract

List of Contents

List of Figures

L1st of Tables

List of Appendices

Executive Summary

1. INTRODUCTION

1

2. SCOPE OF PROGRAMME

1

3. OBJECTIVES

1

4. LITERATURE STUDY - (TASK 1)

1

5. SELECTION OF COMBUSTION SYSTEMS

6. TEST ENGINES

7. TEST FUELS $\quad \cdot \cdot 7$

8 EXPERIMENTAL DETAILS 99

9. ENGINE TEST BENCH AND INSTRUMENTATION : : 10

10. ANALYSIS OF RESULTS

11. RESULTS AND OBSERVATIONS - MULTICYLINDER DIESEL SCREENING TESTS - (TASK 2) 13

12. RESULTS AND OBSERVATIONS - FUNDAMENTAL PROGRAMME - (TASK 3)

13. DISCIISSTON 39

14. CONCLUSIONS 42

15. RECOMMENDATIONS 43

16. ACKNOWLEDGEMENTS

17. REFERENCES 
1. Śchematic Diagratn of the Indirect Injection Diesel Combustion System 4

2. Schematic Diagram of the Direct Injection Diesel Combustion System 5

3. Schematic Diagram of the Spark Ignited, Indirect Injection Combustion System 5

4. Schematic Diagram of the Texaco TCCS Combustion System . .

5. Schematic Dlagram of the MAN FM Combustion System 5

6. Measured Motoring Loss Friction Characteristics - Multi - and Single Cylinder Engines - Fundamental Study.

7. Representative Multicylinder Motoring Loss Friction Characteristics for Englnes of c. 2-2.5 Litres Capacity in Four Cylinders.

8. Envelopes of Relative Brake Specific Energy Consumption (Phi111ps D2 = 1.00) - A11 Speeds.

9. Envelopes of Relative HC Erissions (Ph11lips D2 $=1.0$ ) - A11 Speeds.

10. Envelopes of Relative NOx Emissions (Phillips D2 $=1.0$ ) - All Speeds.

11. Envelopes of Relative Co Emissions (Phillips D2 = 1.0) - Al1 Speeds.

12. Envelopes of Exhaust Smoke - All Speeds.

13. Comparisons of Smoke Limited BMEP

14. Performance and Emissions at $25 \mathrm{rev} / \mathrm{s}$ (1500 rev/min) - IDI Diesel Combustion System

15. Performance and Emissions at $40 \mathrm{rev} / \mathrm{s}(2400 \mathrm{rev} / \mathrm{min})$ - IDI Diesel Combustion System

16. Smoke L1mited BMEP Curves - IDI Diesel Combustion System 20

17. Performance and Emissions at $25 \mathrm{rev} / \mathrm{s}(1500 \mathrm{rev} / \mathrm{mln})$ - DI Diesel Combustion System. 21

18. Performance and Emissions at $40 \mathrm{rev} / \mathrm{s}(2400 \mathrm{rev} / \mathrm{mI} \mathrm{n})$ - DI Diesel Combustion System 21

19. Smoke Limited BMEP Curves - DI Diesel Combustion System 22

20. Performance and Emissions at $25 \mathrm{rev} / \mathrm{s}(1500 \mathrm{rev} / \mathrm{min})$ - SIIDI Combustion System 22

21. Performance and Emissions at $40 \mathrm{rev} / \mathrm{s}(2400 \mathrm{rev} / \mathrm{m} 1 \mathrm{n})-\mathrm{siIDI}$ Combustion System 23

22. 3ü̈ke Limited BHEP Curvco - SIIDI Combustion Syerem 23

23. Performance and Emissions at $25 \mathrm{rev} / \mathrm{s}(1500 \mathrm{rev} / \mathrm{min})$ - Texaco TCcs Combustion System 24

24. Performance and Emissions at $40 \mathrm{rev} / \mathrm{s}(2400 \mathrm{rev} / \mathrm{min})$ - Texaco TCcs Combustion System 24

25. Smoke Limited BMEP Curves - Texaco TCCS Combustion System 25

26. Performance and Emissions at $25 \mathrm{rev} / \mathrm{s}(1500 \mathrm{rev} / \mathrm{min})$ - MAN FM Combustion System 26

27. Performance and Emissions at $40 \mathrm{rev} / \mathrm{s}(2400 \mathrm{rev} / \mathrm{min})$ - MAN FM Combustion System 26

28. Smoke ul Detuilation Limited BMEP Curves - MAN FM Combugtion System 27

29. Startability Evaluation - IDI Diesel . 28

30. Comparison of Misfire Regimes - IDI Diesel - $70 \mathrm{rev} / \mathrm{s}$ (4200 rev/min) 1 Bar BMEP (100 $\mathrm{kPa}$ ) 
31. MAN FM - Regimes of Autolgnition and Detonation Limits

32. IDI and DI Diesels Comparisons of Observed Ignition Delay with Respect to Measured Cetane Number.

33. Comparison of Maximum Cylinder Pressures at Full Load

34. Comparison of Rate of Pressure Rise

35. Envelopes of Brake Specific Fuel Consumption - All Fuels

36. Envelopes of Indicated Specific Fuel Consumption - All Fuels

37. Envelopes of HC Emisstons - All Fuels

38. Envelopes of NOx Emissions - All Fuels

39. Envelopes of Exhaust Smoke - A11 Fuels

40. Envelopes of Maximum BMEP - All Fuels

41. Ënvelopes of P̃articulate Emissions - Al1 Fuels

42. Envelopes of Co Emissions - All Fuels 


\section{LIST OF TABLES}

Page No.

Table 1

Description of Combustion Systems and Test Englnes - Multicylinder Diesel Screening Tests - (Task 2).

Table 2

Description of Combustion Systems and Test Englnes - Fundamental Study - (Task 3).

Table 3

Fuel Inspection Data - Multicylinder Diesel Screening Tesț - (Task 2).

Table 4

Fuel Inspection Data - Fundamental Study - (Task 3).

Table 5

Estimated FTP Results with Test Engines in 2500-3000 Ib Vehicle. 


\section{LIST OF APPENDICES}

1) Brief History and Description of Combustion Systems Evaluated.

2) Fuel Handling System used throughout the Programme to Prevent Vapour Formation.

3) Conversion of Gaseous Emissions Data from Volumetric to Specific Gravimetric Units.

4) Detail Curves. Multicylinder Diesel Screenling Tests - (Task 2 ).

5) Minimum Fuel Consumption Timing Plans - All Systems - Fundamental Study - (Task 3).

6) Brake Speciflc Energy Consumption - All Fuels and Systems - Fundamental Study (Task 3).

7) Emission Trade-offs - All Fuels and Systems - Fundamental Study - (Task 3 ). 


\section{EXECUTIVE SUMMARY}

\section{INTRODUCTION}

Concern over assuring supplies of energy in the future has led the US to enbark upon the development of alternative fuels including synfuels manufactured from coal and o11 shale. In line with such developments, realization of the necessity to examine the 11kely 1mpact of future fuels upon the systems that will be subject to their use has resulted in studies of the type presented here.

Th1s Executive Summary provides a synopsis of the flnal report of a programme of work sponsored by the US Department of Energy examining the Interactions between several comblnations of fuels and light duty automotive combustion systems.

\section{SCOPE OF PROGRAME}

The programme was conducted over a three year perlod and comprised three main tasks:-

Task 1 - Literature Study

Task 2 - Multicylinder Engine Screening Tests Indirect and direct injection diesel combustion systers.

Task 3 - Fundamental study - single and multicylinder engines - Indirect and direct Infection diesel and stratified charge combustion systems.

A separate report covering Task 1 the literature study was published on completion of that task. Tasks 2 and 3 are reported together in the main body of this document.

\section{OBJECTIVES}

The alm of the programme was to provide a data base from wh1ch the 1mplications of using future syncrude derived fuels on the operation of automotlve power plants, particularly light duty, may be judged.

\section{SELECTION OF COMBUSTION SYSTEMS}

In selecting combustion systems for evaluation during the experimental phases of the programme, it was decided to utilise both indirect (IDI) and direct injection (DI) diesel combustion systems during both the screening study (Task 2) and the fundamental study (Task 3). Furthermore, during Task 3, evaluations would be made of various spark ignited stratified charge systems, one having indirect injection (SIIDI) and two with direct injection (Texaco TCCS and MAN FM).

The IDI and DI diesel combustion systems were selected because of their 1mportance as the most fuel efficient power plants widely used for automotive purposes. The spark ignited stratified charge systems were all selected as a result of previously demonstrated multifuel capability and the potential for good fuel econony. As a result of a combination of chosen strategles and Imposed technical constraints, the final selection of engines evaluated was as follows:-

Task 2 - FIAT 8140 multicylinder indirect injection diesel

RICARDO 1.81 multicylinder, direct injection diesel research englne (Multiple fuel spray combustion system)

Task 3 - RICARDO HYDRA single cylinder, Indirect injection diesel (based on FIAT 8140)

RICARDO HYDRA single cylinder, MAN FM

RICARDO HYDRA single cylinder, spark Ignited indirect injection

WHITE L-163-S, multicylinder, Texaco TCCS

RICARDO 1.81 multicyilnder, direct injection diesel research engine.

A11 combustion systems were based upon cylinder sizes and speed ranges commensurate with light duty applications. The design and procurement of the single cylinder engines formed an integral part of the overall contract.

\section{SELECTION OF FUELS}

For the selection of fuels, different strategles were adopted for Tasks 2 and 3 .

Task 2 fuels were selected to screen the diesel engines for tolerance to variations in:-

a) Ignition quality - this being achleved by evaluating the engines with Phillips D2 as reference, and also w1th D2 following the additions of small quantities of additives to adjust the ignition quality whilst malntalning distillation characteristics constant. Cetane ratings of 38 - 51 were examined.

b) volat1lity - this being achleved by selectively blending naphtha and diesel fuels to result in fuels with similar ignition qualtities to Phillips D2 but having distinctly different distillation characteristics.

The alternative strategy utilized for Task 3 was adopted in order to cover wider fuel groups covering the maln specifications of potential candidate fuels dervied from coal and oll shale.

In achieving this Phillips D2 was again adopted as the reference fuel. In addition, the D2 was blended with quanticles of a low ignition quality (27 Cetane Rating) stralght run naphtha in order to address the potential broadcut option. Unblended naphtha was also evaluater. 
Further evaluation was also made with a low ignition quality, highly aromatic diesel type fuel obtained as a result of blending light Cycle 011 with a quantity of diesel fuel.

Throughout the programue, all fuels utilized were of petroleum derived stocks owing to the nonavallability within the programe time-scale of sultable synfuels.

\section{SCOPE OF TEST WORK}

During the Task 2 screening study, each fuel was evaluated in both the IDI and DI diesel engines over the entire operating range of the systems. Infection timing was left at the standard settings derived for conventional dipsel fuel and no opt 1mization was therefore attempted. During these tests performance, economy, smoke and gaseous éfissions measurements were made.

For Task 3, fuels were primarily 1.nvestigated in all combustion systems over the load range at two selected test speeds belng representative of typical urban light duty operation (25 and $40 \mathrm{rev} / \mathrm{s}, 1500$ and $2400 \mathrm{rev} / \mathrm{m}(\mathrm{n})$. Rated speed for each combustion system was also examined.

With each engine/fuel combination, combustion timing was varled as appropriate to assess the potential of the combination when operating under conditions of maximum economy. Measurements were made of performance, economy, smoke, gaseous and particulate emissions. Observations were made upon startability, engine deposits/condition and quality of lubricating oll.

With the exception of the Task 3 startability evaluations, all test work during Tasks 2 and 3 was undertaken under hot engine running conditions.

\section{DISCUSSION}

From the Task 2 screening tests both the IDI and DI diesels were judged to be generally fuel tolerant. The results from this Task justified the inclusion of these systems within the fundamental study, Task 3 , urilizing the wuch wider ranging fuel apcetficativina.

From the results of this programme it can readily be demonstrated that given the avallability of high Ignition quality fuels in the future, the diesel engine is expected to continue to dominate unthrottled automotive applications. However, development of the multiple fuel spray lit. system must continue, to improve baseline torque and emissions characteristics with respect to the IDI diesel, if advantage is to be taken of its $10 \%$ lower fuel consumption. Other DI systems, such as the MAN Controlled Direct Injection (CDI) have potential benefits for light duty applications and their inclusion in further studies should be encouraged. of the stratified charge systems evaluated only the TCCS exhibited the abllity to run on high ignition quality diesel fuels although available corque was low and emissions generally hIgh.

With the high ignition quality broadcut fuels the diesel englnes proved to be entirely sultable. of the spark ignited engines the MAN FM was unsuitable for these fuels due to uncontrolled combustion which cestricted its speed range. This should be overcome by detalled development for the fuel. The SIIDI and TCc.s systems operated oucccasfully. T.t is thought unlikely that with such fuel being avallable the diesel englne would be usurped by the stratifled charge engine owing to the design and development effort required and the baseline torque and emissions disadvantages of the stratified charge engine with respect to the IDI diesel in particular.

For operation on stralght run naphtha, the results obtalned indicate lial uider hut running conditions, the Tnt diegel generally rcturned conjuelllive haspline porfarmanoo, omboolono cte. iviüpaited wlll D2 operation. Its sultability for such fuels is however dictated by whether or not the system can be developed for successful. cold stareing and running, acceptable nolse characteristics and low NOX emissions using injection retard and or exhaust gas recycle. Given the overall superior baseline emissions characteristics and torque potential of the IUI diesel with respect to the stratified charge engine, it 18 belleved that work should be encouraged to see whether the IDI dlesel can be successfully adapted with naphtha type fuels in the aforement loned areas.

With positive 1gnition, the spark ignited otratifled charge engine has no potential problems with naphtha type fuels. The SIIDI systen evaluated here was not successfuly run on naphtha fuel however owing to continued oparking plus soutling; a problem which it is belleved may he overcome by specifically directed development. Both the TCCS and FM systems were successfuly evaluated. of these, the FM emlts lower HC emissions owing to the lise of nintle injogtoro. Smoke, torquc, high luad fuel econothy and particulate emission advantages relative to the TCCS system were also apparent although the latter exhibits a lower Nox baseline. Work should be continued however to compare well developed multicylinder versions of each for better overall judgement since the apparent advantages of the single cylinder FM system noted during this programme may have been enhanced by the lack of any cylinder lu cyllinder diseribution problem of atr flow, air swirl and injection/ignition timing. Furthermore, the FM system had significantly better and more representative volumetric efficlencies than the multicylinder White L-163-S englne used to evaluate the TCCS sygtem.

Those multicylinder cursparlsons should run concurrently with the recommended IDI diesel studies.

Fuel vapourization problems within the injection pump encountered during this programme with naphtha as fuel in the DI diesel englne precludes any comments beling made.

When operating on low ignition quality broadcut fuels, the sultability of combustion systems 18 
again difficult to judge. The IDI diesel cannot be dismissed on the data obtained as, under hot running conditions, similar baseline performance, emissions etc. compared to D2 operation were obtalned. Doubts remain however concerning cold operation, nolse and tolerance to retard for low NOx.

The spark ignited stratifled charge engine is naturally suited to fuels of this type although baseline torque, emissions etc. characteristics are typically worse than those for the IDI diesel, particularly in the case of HC entssions with the open chamber stratifled charge engine. Because of this, the degree to which the IDI diesel can be adapted for successful overall operation with fuels of this class should again be examined as per previous comments for naphtha as fuel. Simultaneous well developed multicylinder stratifled charge engine comparisons should be obtalned for a full understanding.

The DI diesel was not evaluated on fuels of this class for the same reasons previously discussed with naphtha as fuel.

Operational problems were experienced with the diesel engines and the low ignition quality, highly aromatic diesel fuel. In the case of the IDI, this Involved distinctly inferior starting in addition to problems expertenced and related to regimes of misfire and HC penalties at low speed. With the DI diesel, no misfire reglimes were experienced although very rough ldling following starting was encountered.

In view of these operational problems, spark Ignlted stratified charge engines may seem attractive for fuels of this class. Of the open chamber systems evaluated here thelr reduced torque avallability and environmental penalties relative to the IDI diesel were still evident. Because of this and desplte the aforementioned problems with the IDI diesel, the overall torque potential and baseline emission characteristics of the IDI system with fuels of th1s class are thought to again provide incentive for continued examination as to whether the IDI diesel can be suitably adapted. These programmes should be concurrent with further multicylinder stratified charge engines including the SIIDI systems not addressed within this programme on this fuel group owing to time-scale limitations.

Although the multiple fuel spray DI diesel apparently proved more tolerant than the IDI with fuels of this class, similar incentives for continued study are less apparent. since its emissions and torque penalties relative to the IDI diesel were retalned. In fact, the latter situation was exacerbated at low speed with fuels of this class.

\section{CONCLUSIONS}

Based upon the results from this programme and the discussions formulated, the following conclusions are drawn complementing those reached on completion of the Task 1 Literature Study.

1. The swirl chamber IDI and multiple spray DI diesel systems examined proved to be fuel tolerant, demonstrating the ability to be successfully evaluated over a wider range of fuels than had been anticipated. The concept of fuel tolerance was augmented by the fact that significant detrimental effects relative to the baseline performance and emissions characteristics with D2 fuel were not generally apparent.

2. As expected, spark 1gnited stratified charge engines are capable of operation over a wide range of fuels. The MAN FM and SIIDI systems evaluated here proved intolerant however to fuels with high cetane ratings, although it is anticipated that this could be overcome by detalled development. The Texaco TCCS operated successfully Irrespective of fuel type.

3. Of all the combustion systems examined, the IDI diesel returned overall superior baseline torque and emissions characteristics irrespective of fuel type.

4. For future high ignition quality diesel and broadcut fuels, the diesel engine is expected to remain dominant for light duty applications. Despite an economy advantage of typlcally $10 \%$ the multiple spray DI diesel will not compete with the IDI diesel given that current US emissions standards are not relaxed.

5. The observed overall baseline torque and emission advantages of the IDI diesel dictate that continued evaluation should be carried out to ascertain whether it can be adapted for successful cold starting and running, acceptable noise and the attainment of low NOx (retard and/or EGR) with low ignition quality naphtha, broadcut and diesel fuels. Of these, it is anticlpated that the latter will be most problemat1cal.

6. W1th positive Ignition, scope naturally exists in respect of operational characteristics for stratifled charge engines with future low Ignition quality, low octane fuels. Concurrent with the continued evaluation of the IDI diesel, comparisons of well developed, multicylinder stratified charge engines must be undertaken if overall cholce of a candidate system is to be made.

7. Irrespective of fuel, open chamber stratified charge englnes (MAN FM and Texaco TCCS) exh1b1t baseline emissions penalties, particularly of HC, and significant control measures will be required. This problem is reduced in the FM system by the use of pintle injectors although NOx emissions are higher. 'In the absence of high octane fuels, torque levels equivalent to the IDI diesel are unlikely to be attained although consumption advantages are possible.

8. Development of the swirl chamber spark Ignited engline may alleviate the HC penalties characteristic of the open chamber systems. Consumption advantages are however lost and torque and Nox emission penalities relative to the IDI diesel remain.

9. The interaction between fuels and engines is complex. Much more work, including the assessment of other combustion systems and actual synfuels must be undertaken for a full understanding. 


\section{INTRODUCTION}

Since the discovery of crude ofl in commerclal quantitles fust over a century ago, the production of hydrocarbon fuels has been showing a healchy growth rate both in absolute terms and as a proportion of the overall energy market. During this perlod, the United States has developed not only as the largest user but also as a major importer of this energy source, and low prices have not only favoured demand but has also inhibited the exploitation of domestic reserves.

More recently however, high prices on the world market and a growing awareness of the susceptibility to political control and the finite nature of crude o 11 supplies has led to Increased efforts to lmprove vehicle economy and exploit alternative energy sources.

Although major energy sources traditionally exploited within the United States have been ofl and coal, current pollcies are directed not only to Increased production from these sources but also to exploitation of the significant deposits of ofl shale, which have been utilized in small quantities in the past in order to satisfy demand for superior lighting olls, but have not until now been economical to extract in sufficient quantities to sat1sfy modern demands.

W1th regard to future transportation, it is expected that vehicle fleets will contain, well into the twenty-first century, a large proportion of vehicles similar to those produced today owing to the life expectancy of current models, the long lead times and high costs necessary to introduce radically new vehicles and the natural conservatism of the consumers. It is also envisaged that the characteristics which have popularized current liquid fuels - 1.e. relative accessibility, handling conventence, high stored energy density and ease of conversion to thermal energy - will be retained for future fuels. Thus, future vehtcle fleets will in all probability be mainly powered by engines and liquid fuels similar to those avallable today, and novel prime movers or fuels will be in the minority.

It theretore seems an arcractive sulutiul cur the United States to develop a syncrude industry manufacturing liquid hydrocarbon fuels from its coal and ofl shale reserves. However, when consldering such an alternative the trade-off between production costs, fuel specifications and technical implications in use must be studied.

This report detalls an experimental programme sponsored by the US Department of Energy (DOE) which has been conducted with the objective of compliing data to enable assessment of the interaction between fuel specification and specific light duty automotive combustion systems.

\section{SCOPE OF PROGRAMME}

The total programme was conducted over a three year perlod from January 1980 and comprised three main tasks as follows:

Task 1 - Literature Study

Task 2 - Multicylinder Englne Screening Tests indirect and direct injection diesel engine combustion systems.

Task 3 - Fundamental Study - single and multicylinder englnes - indirect and direct injection diesel and stratifled charge combustion systems.

The 11terature study was carried out during 1980 and has previously been reported and published (1).* This Task is not reported here although the conclusions and recommendations are reiterated.

This report only covers the experimental phases (Tasks 2 and 3 ) of the programme. Task 2 was undertaken during 1980 and the first quarter of 1981. As an 1ntegral part of Task 3, the Ricardo Hydra (2) single cylinder englne utilized for some of the experimental work was designed in 1980 and procured in 1980/81. The Task 3 engine test phase was carried out during $1981 / 82$.

\section{OBJECTIVES}

The aim of the programme was to provide a data bank from which the implications of using future syncrude derived fuels upon the operation of automotive power plants, particularly light duty, may be judged.

For the experimental phases reported here, the specific objectives may be summarized as follows:

Task 2 - To screen the fuel tolerance of contemporary light duty diesel engines.

Task 3 - To examine the fuel tolerance of both light duty diesel and spark 1gnited stratified charge combustion systems with optimised combuction timing.

\section{LITERATURE STUDY - (TASK 1)}

In this report, the conclusions from Task 1 are reiterated as follows:

a) Considering the extensive worldwide utilization of diesel engines with a variety of combustion chambers and different applications, there is relatively little information avallable from structured programmes on the detalled effects of fuels and fuel variables related to the many facets of engine operation.

* Numbers in parentheses designate references at end of report. 
b) In the avallable literature there are many conflicts and areas of insufficlent data and it is impossible to predict the overall effect of fuel varlables upon diesel englne operation.

c) Insuffictent data is avallable to evaluate syncrude derived products or to know whether syncrude products, having the same bastc specification as petroleum derived products, behave in a simllar fashion.

d) The data currently avallable on the influence of fuels and fuel variables has been acquired whout recourse to englne reoptimization for fuels. In addition, the light duty IDI diesel engine requires more detalled attention. Future work should, therefore, cover a wider range of diesel engines and optimization of the engines for the various test fuels used.

e) 1) For fuels of very low ignition quality, spark ignited stratitied charge engines will probably be required as they have been demonstrated to have good fuel tolerance. (N.B. Throughout this report reterence to low or high ignition quality relates to fuel cetane number established by CFR engine).

11) For fuels of relatively high ignition quality, reoptimlzed diesel englnes should be sultable.

111) For fuels of intermedlate ignition quality, 1.e. c.30-35 cetane number, it is not clear without further data which type of combustion system would be most suitable.

F) A significant reduction in fuel ignition quality will require considerable design and development effort, elther to adapt diesel engines or to apply spark 1gnited stratifled charge englnes on a large scale.

g) A large amount of carefully structured test work is required to obtain detalled Information to understand fully the implications of future fuels upon the uperation of engines with vurlous eonbustion sysl ems.

on completion of Task 1 the following recommendations were made:-

a) Cuntliue lo updare the literature study particularly as regards synfuel operation because more dala is likely to be generated in this area in the near future.

b) Give high priority to making synfuels available for future test programmes.

c) Give consideration to other potentially fuel tolorant combustion systems.

d) Define a test programme which will provide the required information in the areas where insufficient data currently exists.

e) Study the trade-off between the refinery implications of maintaining fuel quality so that existing diesel engines and design phllosophy can be retained against reducing fuel quality with the attendant research and design/development implications, particularly wh regard to lead time for production.

The conclusions reached and recommendations made on completion of Task 1 justified continuation with the experimental phases of the programme as reported in this document.

\section{SFI.F.CTION OF COMBUSTION SYSTEMS}

For the experimental phases of the programme it was decided (3) to evaluate both indirect (IDI) and direct injection (DI) diesel combustion systems within both the screening study (Task 2) and the fundamental study (Task 3). The spark igntter. stratified charge systems chosen for evaluation within. Task $\rightarrow$ reprogonted an indirost injceelon (4) eyçtam (spark 1gnitcd. IDI (EIIDI)) and two dliecl Iniection systems (Tararn rontroliod oombuotion system (TCCS) and MAN FM ( $=$ Fremdzundung = extraneous 1 gnition, $M=$ Meurer)). The inclusion of both the TCCS (5) and FM $(6,7)$ systems resulted from the signiflcant differences in fuel preparation within the cylinders between the two systems.

For each of the above combustion systems, cylinder sices and speed ranges relevant to light duty, automotive applications were ut111zed.

The IDI and DI diesel combustion systems were selected for Tasks 2 and 3 because of their Importance as the wost fuel efficlent power plants widely used for automotive purposes. It was, therefore, considered necessary to evaluate whether variation in fuel specification resulting from increasing use of synfuels will compromise their operational characterigtics.

The spark Ignited systems chosen for evaluation all represent "late" injection types (1.e. injection commences later than $50^{\circ}$ crank before top dead centre (BTDC) on compression yliuke). These syscems have each demonstrated mult1-fiel capability. particularly the MAN FM and Texaco TCCS processes which have been subject in the past to much development effort. All of the systems are unthrottled with the potential for high thermodynamic efficiency. By emplnying "lare" Injection, excesstve levels of premlxed combustion can be avoided with the theoretical elimination of fuel octane requirement. The addition of a positive ignition source in the form of a sparking plug also avofdo the icyultement fur high eecane rues as are necessary for the compreseion ignition engine.

A further gain also results from the use of spark ignition; although it is common knowledge that increasing compression latio cheorerically leads to Improvements in cycle efficlency, it must not be overlooked that it also increases engine friction levels. A polnt is thus reached beyond which, any improvements from increasing compression ratio are offset by increased friction, resulting in reduced brake performance. An optimum compression ratio 
w111, therefore, exist for any given engine, it being generally accepted that this will be tn the region of $15: 1$.

In the case of the light duty IDI and DI diesel engine, which rely on the self ignition qualtties of the fuel, such a compression ratio would be unacceptable not only for cold starting, but also for light load operation, particularly with cold ambient intake air. For successful overall operation, the light duty IDI diesel requires compression ratios of typically 20-23:1. The open chamber design of the light duty $D I$ diesel enables some reduction in compression ratio although values of typically $20: 1$ are still required.

The light duty diesel, therefore, operates with compression ratios which are high relative to the optimum thermodynamic/friction trade-off value for best brake performance.

With spark lgnition, the stratifled charge englne can achieve successful operation with compression ratios closer to the optimum trade-off value and thereby has the potentlal for good brake performance. The lower compression ratios employed with the spark lgnited systems have the further advantage of reducing peak firing pressures which in turn reduces mechanical loading allowing these systems to be converted from existing gasoline engines, thus enabling potential cost benefits relative to the 11 ght duty diesel.

\section{TEST ENGINES}

\section{ORIGINAL STRATEGY}

Whilst two modern multicylinder diesel englnes were to be utllized for the screening tests (Task 2), the original intention of the fundamental study (Task 3) was to evaluate all five combustion systems on single cylinder Ricardo Hydra research engine (2) maintaining uniform cylinder. sizes between systems. Additionally, common cylinder sizes would be maintained between both Tasks 2 and 3 . As discussed later in this section this ideal was eventually compromised.

As a result of the inaugural meeting (3) held to define the programme strategy concerning combustion systems, test eng1nes and fuels it was decided to ut1lize the European production F1at 8140 IDI diesel engine. (8) and 1tg pre-production DI derivative for the Multicylinder Screening Tests.

The selection of these Flat combustion systems as a basis for the programme was guided by the following reasoning:-

a) Both engines have the same cylinder size which is also broadly representative of US design philosophy for light duty applications.

b) Both engines are designed for speed ranges commensurate with light duty applications (70 $\mathrm{rev} / \mathrm{s}, 4200 \mathrm{rev} / \mathrm{min}$ ).

c) Within the original timescale of the programme, englnes Incorporating IDI and DI combustion systems and encompassing points a) and b) could only be satisfled by the Fiat 8140 design.

d) The Fiat 8140 DI engine was potentially close to European production release thereby having reached a sultable development status. The Fiat 8140 IDI engine represents a typical, well developed production IDI combustion system.

e) The Flat IDI engine was already installed at Ricardo and avallable for the programe. Supply of a DI unit was assured by Flat.

f) To achleve commonality between Tasks 2 and 3 , the Flat IDI and DI designs could readily be incorporated within the Ricardo Hydra single cylinder engine to be uttlized for Task 3 of the contract, whilst also assisting the procurement of the single cylinder engine owing to the avallability of many fiat parts.

\section{MODIFICATIONS IMPOSED ON ORIGINAL STRATEGY}

On completion of the Task 2 IDI tests, Initial results with the Fiat $D I$ unit operating on standard European specification dlesel fuel gave some cause for concern. In discussions between Ricardo, Flat and $D O E$ it was agreed that this eng1ne, st111 under development by Flat, was not yet truly representative of its class. It was decided therefore that a change in the cholce of DI dlesel was required to enable fair evaluation of this combustion system. A review of avallable alternative candidates led to the selection of the Ricardo 1800 DI, multicylinder, light duty diesel research engine (9). This selection was endorsed by DOE.

This engine had previously been modified by Ricardo to DI from a standard production British Leyland 1800 IDI diesel engine for internal research into the high speed, light duty, DI diesel. Although tt is not a production engine, levels of performance, emlssions etc. were regarded as compatible with the technical requirements of the programe. Whilst the original ideal of maintalning uniform cylinder size, etc. Within Task 2 was lost this change did enable unacceptable delays to the programme to be avolded.

With regard to the common single cylinder ideal Intended for Task 3, compromises were again necessary. The first of these resulted from the fact that Texaco did not at that time have to hand design input for a single cylinder TCCS based upon the cylinder size and speed range of the Flat 8140 . Following discussion, Texaco recommended using the multicylinder White $\mathrm{L}-163-\mathrm{S}$ eng1ne. Th1s eng1ne has a swept volume per cylinder about $10 \%$ greater than the Fiat design. After discussion with DOE, it was agreed that this route should be adopted and arrangements were made for an eng ine to be furnished by the US Department of Energy.

The second deviation from the single cylinder ideal for Task 3 resulted from the above mentioned problems which were encountered during Task 2 with the Flat DI eng1ne. It was readily apparent that $1 t$ would not be advisable to base the single cylinder DI design on the Flat combustion system until the 
latter had been developed nearer to its eventual production bulld. However, owing to the programme time-scale and the lead time required to design and procure the DI Hydra conversion parts it was decided not to pursue the Fiat design for Task 3. An alternative was, therefore, sought and after discussions with DOE it was agreed that this would again be the Rlcardo 1800 DI multicylinder research engine. Although approximately $25 \%$ smallcr on cylinder size than the other systems evaluated duting Task 3 it had the advantages of being a readily available light duty DI diesel combustion system, compatible with the requirements of the programme.

For the remaining combustion systems which retained the originally agreed common single cylinder form, the IDI diesel was based on the Fiat 8140 production englue, do was usted fus Tusk 2, while che r'm anô SIIDI systems were based upon the Flat cylinder size and designed from in-house knowledge with additional Input from MAN for the FM.

Thus, for Task 3, three systems were ultimately evaluated in single cylinder form and two in multicylinder form as follows:

Single Cylinder Indirect injection diesel (IDI)

Spark Ignited, Indirect Injection, stratifled charge (SIIDI),

Spark igntted, direct Injection, stratified charge (MAN FM)

Multicylinder Direct injection diesel (DI)

Spark ignited, direct Injection, gtratified charge (Texaco, TCCS).

Full technical descriptions of the test engines are given in Tables 1 and 2 covering the Task 2 and 3 programes respectively. The compression ratios utilized for each system should be noted in relation to the comments made in the previous section. Schematic diagrams of each combustion system are provided in Figures 1-5, while brief descriptions are given in Appendix 1.

DEVELOPMENT STATUS OF ENGTNES USĖD

The development status of each combustion system examined should be noted here as follows:-

a) The Flat 8140 IDI diesel is typical of a well developed, swirl chamber engine and has been in production in Europe for some time. Whilst it has not been specifically optimised to perform within current Us light duty diesel enissions legislation, Its fundamental design is not significantly different to other systems developed for the US market.

b) The light duty DI diesel is currently being researched by the industry for improved fuel economy and to date no production engtne of the type exists. The research engine evaluated here is a multiple spray design and has been the subject of $2-3$ years development by Ricardo examining the potential of the philosophy for light duty applicattons. At the current status of development, further improvements in smoke inited torque are anticipated but the system has not been developed for US emissions legislation.

c) The Texaco TCCS system examined and covered by the White L-163-S englne has now been under developrent for several years. Its combustion system, ignition source and fuel injection equipment have been developed in the past for multifuel applications and undoubtedly scope would exist for improvements in performance, etc. with development for a specific single fuel.

d) Similarly, the MAN FM system addressed here represents a compromise design, judged at the outset as belng capable of ruunlng on the range of fuels encompassed by the programme. In this case, the system evaluated has not had the multifuel development accorded to the white L-163-S engine. Reasonably, therefore, further benefits from single fuel optimization may be expected. Following procurement, and prior to fuel evaluations, the FM system was not developed beyond basic tuning of the fuel injection system to clear secondary injections.

e) The SIIDI system examined is a design based upon Ricardo experience (4) with an IDI stratifled charge engine developed for multifuel operation. Although in a larger cylinder size, the single cylinder engine tested here was based upon the same design guldelines as previously developed and no optimization or development for the larger cylinder size or specific range of fuels was carried out. In a similar fashion to the FM system, development prior to fuel evaluations was limited to tuning of the fuel injertinn system.

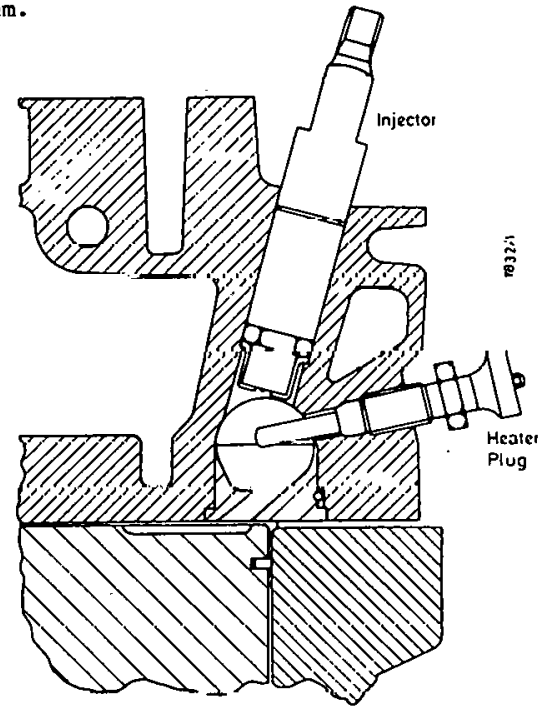

FIGURE 1 - SCHEMATIC DIAGRAM OF THE INDIRECT INJECTION DIESEL COMBUSTION SYSTEM 


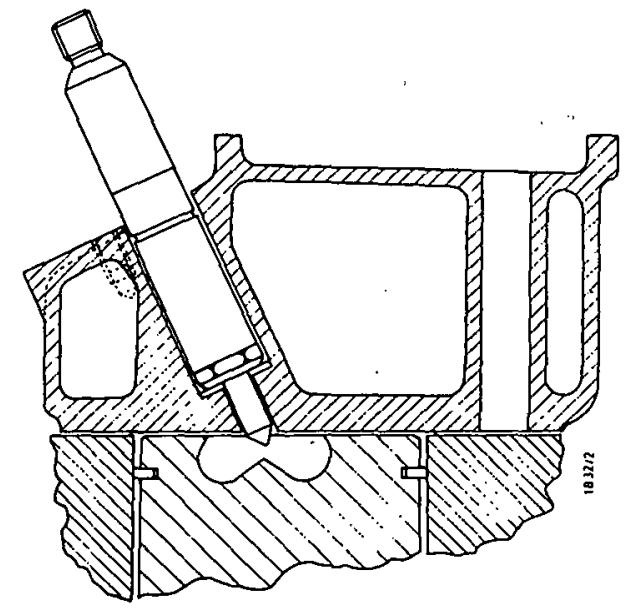

FIGURE 2 - SCHEMATIC DIAGRAM OF THE DIRECT INJECTION DIESEL COMBUSTION SYSTEM

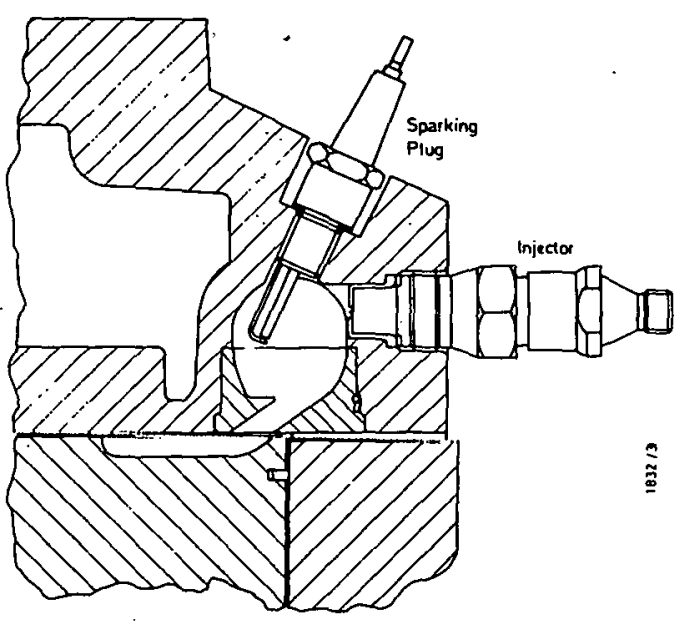

FIGURE 3 - SCHEMATIC DIAGRAM OF THE SPARK IGNITED, INDIRECT INJEOTION COMBUSTION SYSTEM
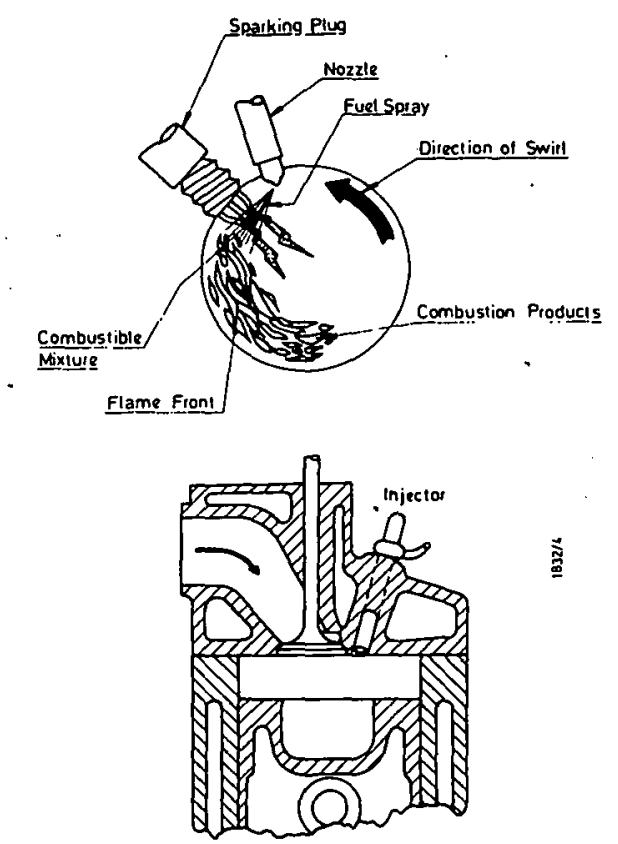

FIGURE 4 - SCHEMATIC DIAGRAM OF THE TEXACO TCCS COMBUSTION SYSTEM

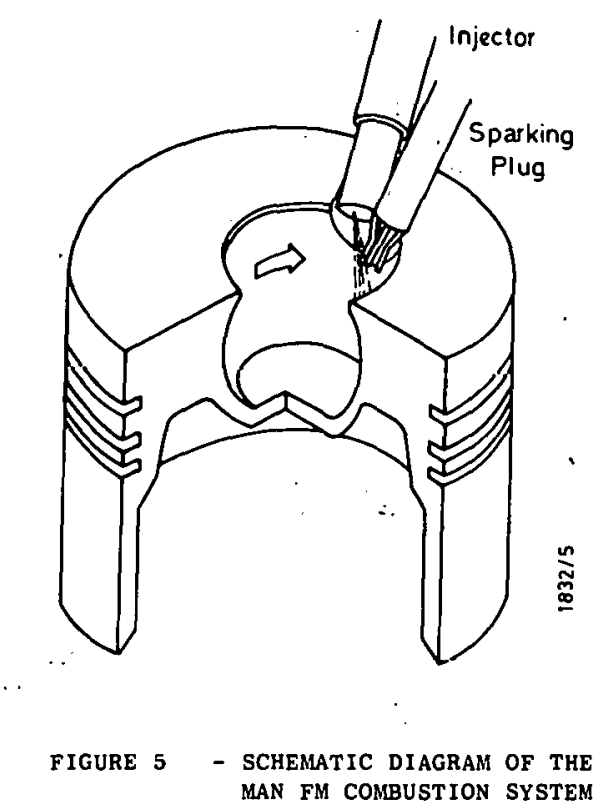


TABLE:. 1

DESCRIPTION OF CONBUSTION SYSTCMS A:D TISTT ENGINES - MULTICYLIIDLR DIESEL SLRLENING TESTS - (TASK 2 )

\begin{tabular}{|c|c|c|c|}
\hline 4 & $\begin{array}{l}\text { Combustion } \\
\text { System }\end{array}$ & $\begin{array}{l}\text { Indirect Injection Diesel - } \\
\text { Swirling Pre-chamber - } \\
\text { Ricardo Comet Mkv }\end{array}$ & $\begin{array}{l}\text { Direct Injection Diesel - } \\
\text { Multiple spray, swirling, rc- } \\
\text { entrant combustion bowl } \\
\text { concentric with injector nozzle sac }\end{array}$ \\
\hline \multirow{12}{*}{--} & $\begin{array}{l}\text { Engine Manufacturer - } \\
\text { Code }\end{array}$ & Fiat 8140 & $\begin{array}{l}\text { British Leyland 'B' Series In- } \\
\text { direct Injection Diesel - adapted } \\
\text { by Ricardo for high speed, direct } \\
\text { injection research. }\end{array}$ \\
\hline & cycle & a stroke & 4 stroke \\
\hline & Bore/Stroke $(\mathrm{mm})$ & $93 / 90$ & $80 / 89$ \\
\hline & No, of cylinders & 4 & 4 \\
\hline & Capacity (litres/cylinder) & 0.611 & 0.447 \\
\hline & $\begin{array}{l}\text { Compression Ratio } \\
\text { (Nominal) }\end{array}$ & $22: 1$ & $20: 1$ \\
\hline & Aspiration & Natural & Natural \\
\hline & Fuel Injection Pump. & Rotary, Bosch EPVE & $\begin{array}{l}\text { Rotary, Bosch EPVE - high pressure, } \\
\text { wLli mlinillu trapped volumé }\end{array}$ \\
\hline & $\begin{array}{l}\text { Fuel Injecliun } \\
\text { Nozzles }\end{array}$ & bosen - Conventional pintle & 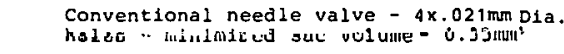 \\
\hline & Rated Speed (rev/s/rev/min) & $70 / 4200$ & $70 / 4200$ \\
\hline & Rülied Power (XH, HF') & $55 / 74$ (produetion rating) & c. $32 / 43$ (al: cuscrent davelopment status) \\
\hline & $\begin{array}{l}\text { Rated Speed/Power quoted } \\
\text { for following fuel }\end{array}$ & $\begin{array}{l}\text { European Specification Diesel } \\
\text { Fuel }\end{array}$ & European Specification Diesel Fuel \\
\hline
\end{tabular}

DESCRIPTION OF COMBCSTIO: SISTEMS AND TEST TANGINES - FUNDAMENTAL STUDY - (TASK 3 )

\begin{tabular}{|c|c|c|c|c|c|}
\hline $\begin{array}{l}\text { Combustion } \\
\text { System }\end{array}$ & $\begin{array}{l}\text { Indirect } \\
\text { Injection } \\
\text { Diesel- } \\
\text { Swirling } \\
\text { pre-chamber- } \\
\text { Ricardo Comet } \\
\text { Mk V }\end{array}$ & $\begin{array}{l}\text { Direct Injection } \\
\text { diesel - multiple } \\
\text { spray, swirling, } \\
\text { re-entrant } \\
\text { combustion bowl. } \\
\text { concentric with } \\
\text { injector nozzle } \\
\text { sac }\end{array}$ & $\begin{array}{l}\text { Spark Ignited } \\
\text { stratified } \\
\text { charge - Indirect } \\
\text { Injection - Swirling } \\
\text { pre-chamber baecd } \\
\text { on Ricardo comet } \\
\text { Mk V }\end{array}$ & $\begin{array}{l}\text { MAN FM } \\
\text { Spark Ignited } \\
\text { stratified } \\
\text { charge - } \\
\text { difect } \\
\text { injection }\end{array}$ & $\begin{array}{l}\text { Texaco TCcs } \\
\text { (Texaco Controlled } \\
\text { Combustion System) } \\
\text { spark ignited } \\
\text { seracified charge - } \\
\text { direct injection }\end{array}$ \\
\hline $\begin{array}{l}\text { Engine } \\
\text { Manufacturer - } \\
\text { Code }\end{array}$ & $\begin{array}{l}\text { Ricardo } \\
\text { Hydra MkIII/ } \\
1304.80\end{array}$ & $\begin{array}{l}\text { British Leyland } \\
\text { 'B series I.D. I } \\
\text { dipsel adapted by } \\
\text { Ricardo for high } \\
\text { speed direct } \\
\text { injection research }\end{array}$ & $\begin{array}{l}\text { Ricardo } \\
\text { Hydra MkIII/ } 1304.80\end{array}$ & $\begin{array}{l}\text { Ricardo } \\
\text { Hydra MkIII/ } \\
1304.80\end{array}$ & $\begin{array}{l}\text { White Engines Inc. - } \\
\text { L-163-S }\end{array}$ \\
\hline Cycle & 4 stroke & 4 strohe & 4 strukt & 4 stroke & 4 stroke \\
\hline $\begin{array}{l}\text { Duseijuluke } \\
(\mathrm{mm})\end{array}$ & $93 / 90$ & $80 / 89$ & $-93 / 90$ & $94 / 90$ & $101.6 / 82.6$ \\
\hline $\begin{array}{l}\text { No. of } \\
\text { cylindere }\end{array}$ & 1 & 4 & 1 & 1 & 4 \\
\hline $\begin{array}{l}\text { Capacity } \\
\text { (1itres/cyl.) }\end{array}$ & 0.611 & 0.447 & 0.611 & 0.625 & 0.670 \\
\hline $\begin{array}{l}\text { Compression } \\
\text { Ratio } \\
\text { (nominal) } \\
\end{array}$ & $22: 1$ & $20: 1$ & $12: 1$ & $12.5: 1$ & $12: 1$ \\
\hline Aspiration & Natural & Natural & Natural & Natural & Natural \\
\hline $\begin{array}{l}\text { Fuel Inject- } \\
\text { ion pump }\end{array}$ & $\begin{array}{l}\text { Inline - CAV } \\
\text { Minimec mod. } \\
\text { for single. } \\
\text { cylindcr } \\
\text { operation } \\
\end{array}$ & $\begin{array}{l}\text { Rotary, Bosch } \\
\text { EPVE - high } \\
\text { pressure with } \\
\text { minfimuin trapped } \\
\text { volume. }\end{array}$ & $\begin{array}{l}\text { Inline - CAV Minimec } \\
\text { modifled for single } \\
\text { cylinder operation }\end{array}$ & $\begin{array}{l}\text { Inline - CAV } \\
\text { Minimec - mod. } \\
\text { for single } \\
\text { cylinder } \\
\text { operation }\end{array}$ & $\begin{array}{l}\text { Rotary, Roosamaster/ } \\
\text { Stanadyne. }\end{array}$ \\
\hline $\begin{array}{l}\text { Fuel Inject- } \\
\text { ion Nozzles }\end{array}$ & $\begin{array}{l}\text { Bosch - } \\
\text { Conventional } \\
\text { pintle }\end{array}$ & $\begin{array}{l}\text { Conventional needie } \\
\text { valve }-4 \times .021 \mathrm{~mm} d i a \\
\text { holes }-\mathrm{min} \text {. sac } \\
\text { volume }-0.5 \mathrm{~mm}^{3}\end{array}$ & $\begin{array}{l}\text { Bosch - Conventional } \\
\text { pintle }\end{array}$ & $\begin{array}{l}\text { Bosch - } \\
\text { Conventional } \\
\text { pintle }\end{array}$ & $\begin{array}{l}\text { Roosamaster/Stanadyne } \\
\text { conventiuld needle } \\
\text { valve }\end{array}$ \\
\hline $\begin{array}{l}\text { 1ghition } \\
\text { system }\end{array}$ & . & 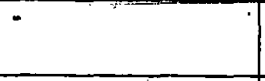 & $\begin{array}{l}\text { Motorcraft - High } \\
\text { Energy Inductive - } \\
\text { Single Strike }\end{array}$ & $\begin{array}{l}\text { Bosch - High } \\
\text { Energy Inductive } \\
\text { Single Strike } \\
\end{array}$ & $\begin{array}{l}\text { Echlin Precision } \\
\text { Ignition Control (EPIC High } \\
\text { Energy multi-strike) }\end{array}$ \\
\hline Spark Plugs & $1-$ & - & $\begin{array}{l}\text { Smiths Industries } \\
\text { Ep5171/1- single } \\
\text { electrode prototype }\end{array}$ & $\begin{array}{l}\text { Smiths Industs } \\
\text { triple electrode } \\
\text { prototype }\end{array}$ & $\begin{array}{l}\text { Champion RNSOiBY - } \\
\text { twin electrode }\end{array}$ \\
\hline $\begin{array}{l}\begin{array}{l}\text { Rated speed } \\
\text { (rev/s/revimin) }\end{array} \\
\end{array}$ & $70 / 4200$ & $70 / 4200$ & $68 / 4080$ & $66.7 / 4000$ & $58.3 / 3500$ \\
\hline $\begin{array}{l}\text { Rated Power } \\
(\mathrm{kW} / \mathrm{HP})\end{array}$ & $13.1 / 17.5$ & $\begin{array}{l}\text { c. } 32 / 43 \text { lat } \\
\text { current development } \\
\text { status }\end{array}$ & c. $10.4 / 13.9$ & c. $11.8 / 15.8$ & $48.5 / 65$ \\
\hline $\begin{array}{l}\text { Rated speed/ } \\
\text { Power quoted } \\
\text { for following } \\
\text { fuel }\end{array}$ & No. $\underset{\text { Fuel }}{2}$ Diesel & $\begin{array}{l}\text { European } \\
\text { Specification } \\
\text { Diesel Fuel }\end{array}$ & Straight Run Naphtha & $\begin{array}{l}\text { Straight Run } \\
\text { Naphtha }\end{array}$ & $\begin{array}{l}\text { Manufacturers quote- } \\
\text { mult } 1 \text {-fuel }\end{array}$ \\
\hline
\end{tabular}




\section{TEST FUELS}

At the Inaugural programme meeting (3) it was declded to use Phillips D2 control fuel as the reference fuel for the diesel combustion system tests within both Tasks 2 and 3 of this programme. It was also decided that since actual synfuels would not be avallable in sufficlent quantitles within the time-scale of this programme, a fuel strategy would be adopted based on petroleum derived stocks.

TEST FUELS - TASK 2

After discussion with DOE the following strategy was adopted for Task 2 .

a) Prime varlables to screen fuel tolerance of combustion systems would be ignition quality (cetane number - $\mathrm{CN}$ ) and volat1lity.

b) To screen the influence of ignition quality two diesel fuels having different cetane number to Phillips D2 but with similar distillation characteristics would be utilized.

c) To screen the influence of volatility - two blends of naphtha and diesel fuel would be utilized providing alternative distillation characteristics to Phillips D2 but blended to malntaln ignition quality at typical D2 values.

In the context of this strategy, it should be noted that varying distillation characteristics by blending lighter naphtha with diesel fuel exploits fuels covering the future broadcut option from syncrude. The rationale behind this strategy is discussed later in this section.

Based upon this strategy, suitable fuels were procured in the UK. Inspection data for these fuels are given in Table 3 . The use of these fuels was ratified by DOE.

From Table 3 it will be noted that small quantities of additives (Tetra-ethyl lead (T.E.L.) and Iso-propyl nitrate (I.P.N.)) were used to vary the Ignition quality of Phillips D2. This approach was used following unsuccessful attempts within the UK to procure stralght diezel fuels having the required ignition quality with typical D2 distillation characteristics. Isolated straight diesel fuels of the required ignition quality had distillation characteristics typically $21^{\circ} \mathrm{C}\left(70^{\circ} \mathrm{F}\right)$ at varlance with D2 at some point on the distillation curve. The use of additives, therefore, enabled the D2 characteristics to be closely maintalned whilst varying ignition quality as shown in Table 3 . Whilst the use of additives is not necessarily representative of future fuels it was considered acceptable for limited screening tests examining the response of diesel engines to Ignition delay alone.

The lower 1gnition quality fuel ( $38 \mathrm{CN}$ ) was selected as representing a "limiting" fuel for the combustion systers whilst enabling data acquisition free of excessive misfire. The upper Ignition quality fuel $(51 \mathrm{CN}$ ) was chosen to represent the ignition quality of European diesel fuels for which both the Fiat 8140 IDI and the Ricardo 1800 DI diesel engines were

PUEL INSPBCTION OATA -

MULTICYLINOER OIBSEL SCREENINC TESTS- (TASR 2)

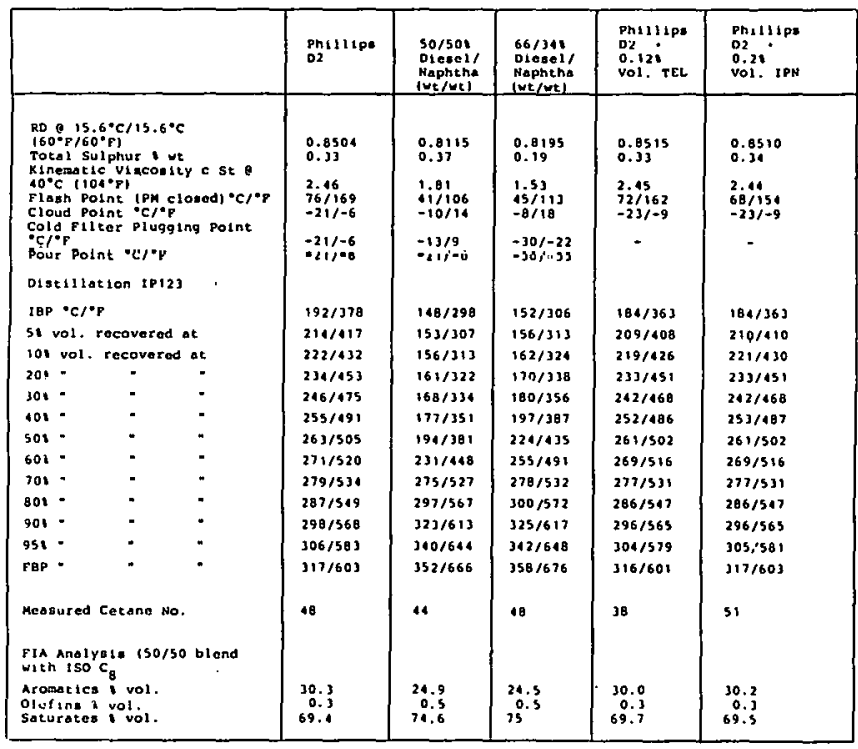

NB - III Tho diosel fuols ysod for tho obove diesol/

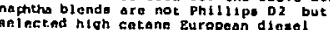
Anato.

(2) Tho sbove blending naphthas are not

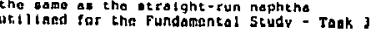


primarily developed whilst also not exceeding a $0.2 \%$ by voluine additive dose rate as specifled by DOE. The ignition quality of both fuels lies outside of typical average values for current D2 fuels.

The two diesel/naphtha fuels conststed of blends of UK diesel fuel ( 57 and $52 \cdot \mathrm{CN}$ ) and a $35 \mathrm{CN}$ naphtha also procured in the UK. (Full inspection data for these blending components is not avallable). The diesel fuel blending components were selected to provide different, relatively high ignition qualities, to enable varlous quantlties of naphtha to be blended, thus achieving different distillation characteristics whilst essentially maintaining Ignition quality (mean of $46 \mathrm{CN}$ ) at the sare value for Ph11lips D2 $(48 \mathrm{CN})$. Note that the higher final. bolling point with respect to Phillips 02 of the two blended fuels arises from utilizing UK diesel fuels as blending components. By blending with naphtha, it will be observed from Table 3 that the intelal to approximately $60 \%$ distillation characteristics are significantly different in comparison with Phillips D2 thereby enabling the influence of higher volatility to be screened.

TEGT FUELS - TA3K 3

For Task 3 a different fuel strategy was adopted in order to cover wider fuel groups. Inspection data for all fuels used during this task are shown in Table 4. In this case Phillips 02 was again adopted, together with a low ignition quality straight run naphtha and 1ntermediate blends of the two. This strategy (and that adopted during Task 2) addresses the possible broadcut fuel option frequently promoted as representing an cnergy efficlent route for processing syncrudes (10). In addition, stralght run naphtha represents a cost effective fuel in refinery terms since no octane upgrading process is required. This fuel design also covers the specification of "reference synfuels For future research" (10) Identffied as a starting polnt by other workers in the field attempting to establish candidate fuels manufactured from syncrudes.

In addition a low ignition quality, highly aromatic, high end point fuel was evaluated. This fuel was manufactured by blending a highly aromatic, catalytically cracked component (Texaco 11ght cycle nf.) with UK specification diesel fucl. A second fuel of this type was evaluated during the IDI diesel programe only and was chosen as representing a "limiting" Euel for the system.

These latter fuels address the trend in diesel fuel as the demand for the lighter fractions further increases whilst demand for the residual fractions reduces, necessitating the manufacture of middle distillates by extensive cracking from the heavier components. furtherwore, the introduction of a highly aromatic component attempts to 11lustrate the possible problems of coal derlved products which are projected to be highly aromatic unless the processing severity. level is signiflcantly raised.

It should again be noted that owing to synfuels not belng avallable for use during this programme, the fuels used were petroleum derived. Although these were selected to bracket the major properties such

1ABLE:

PUEL THSPECTION DATA -

FUNUAAENTAL, STUGY - ITASK S!

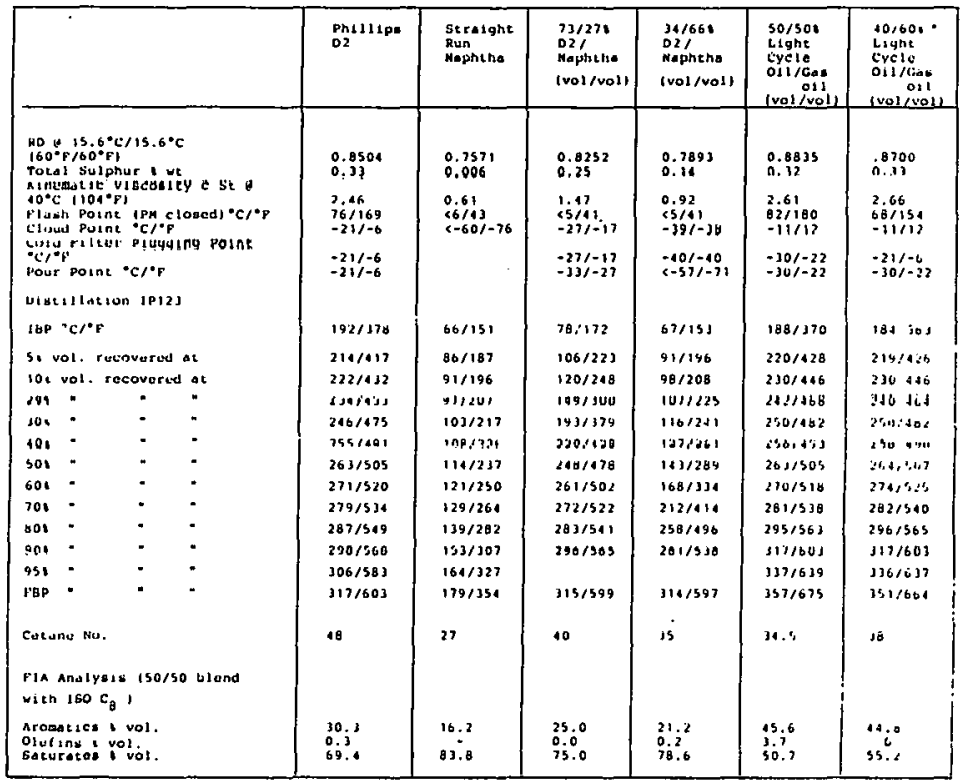

- Evaluated during tol diegel proprasaso only. 
as distillation characteristics and ignition quality of future synfuels, other specific secondary effects from synfuels, such as the influence of fuel impurities on deposits, particulates, etc. could not be investigated. This shortcoming was considered acceptable within the programme objectlves of characterizing the major impact of future fuel specifications.

\section{EXPERIMENTAL DETAILS}

For both screening and fundamental studies precautions were taken to evaluate the full operational capability of each engine. This primarlly required operating each engine up to a liofing level of exhaust smoke, exhaust temperature or peak cylinder pressure. In order to assure reaching a limit, thereby precluding fuel density effects, the peak fuelling levels of the injection pumps were set to supply excess fuel, enabling the limit to be experimentally achieved. In practice exhaust smoke levels were most commonly the limiting constraint, the limits adopted belng purely arbitrary, but reflecting realistic development levels for light duty applications. Where appropriate the exhaust temperature and peak cylinder pressure limits reflected practical levels for development testing. In addition, detonation provided a limit with some of the spark ignited stratifled charge englne tests. For each set of tests with a given combination of engine and fuel a consistent procedure was adhered to for warming up and conditioning the engine exhaust systems and where approprlate the partlculates dilution tunnel. This was undertaken primarily to improve repeatability of gaseous hydrocarbons (HC) and particulate measurements. Using this procedure day to day overall repeatabllity was considered acceptable throughout the programme.

Throughout the tests on all englnes, perlodic checks were made at reference conditions in order to ascertain whether any change was occurring in baseline performance. With one exception, the engines all demonstraterd a high level of baseline repeatability. The exception was the single cylinder IDI diesel which underwent a significant drift in baseline performance part. way through 1 ts programme. This was not a short term repeatability problem since performance had been repeatable at the original levels before the drift occurred, and was again repeatable after the drift at the "new" levels. Since no cause for this drift could be traced and financial and time constraints precluded repeating the work, the results have been accepted and presented with a 'band' of baseline results with D2 fuel for each varlable. Th1s represents a level of confidence in the results and is considered an acceptable approach since the conclusions drawn when comparing fuels within the system or when comparing this systce agalnot the others are not signifirantly affected by the inclusion of this band.

For the multicylinder diesel screening tests (Task 2) both engines were run at conditions covering the entire load and speed range. The fuel infection pumps were timed statically at a compromise (defined prior to this programme) with respect to performance and economy using European specification diesel fuel (typlcally $51-53 \mathrm{CN}$ ) this representing the parent fuel for each system. The scope of work applicable to this task dictated that these timing plans be retained. This approach was considered to be technically justifiable given the relatively high ignition quality $(48 \mathrm{CN})$ of the baseline reference Phillips D2. The tining plan was also not rescheduled to optimize englne operation with the alternative fuels to $D 2$.

The nature of the Fundamental Study denanded that a different approach be adopted. Results for this Task were obtained from operation over the load range at two selected 'key' speeds. A survey of the duration of time spent at varlous load and speed regimes for a selection of light duty engines operating in vehtcles over the Federal Urban Drive Cycle indicated that it would be reasonable to adopt $25 \mathrm{rev} / \mathrm{s}$ ( $1500 \mathrm{rev} / \mathrm{min})$ and $40 \mathrm{rev} / \mathrm{s}(2400 \mathrm{rev} / \mathrm{min})$ as key speeds to represent light duty operation. In addition, rated speed was also examined for each combination of combustion system and fuel in order to evaluate effects on rated performance and to check for any operability problens. Observations were also made of startability, condtion of or deposits on engine and fuel injection equipment components and condition of the lubricating oil.

During the fundamental programme fuel injection and/or ignition timing was varied for each combination of fuel and combustion system primarily in order to investigate operation under conditions of optimum fuel economy whilst also allowing assessment of trade-off effects. (For reasoning behind cholce of optimum fuel economy see later section 10 - Analysis of Results). To achieve these objectives, various procedures were adopted for each combustion system owing to thelr fundamental differences. These are described as follows:-

\section{IDI DIESEL COMBUSTION SYSTEM}

Since this system had not been evaluated in its single cylinder form prior to the programme, initial timing responses at the selected speeds were carried out at high load factor using D2 as fuel. These responses were analysed and a timing requirement for best fuel economy with due regard to enissions selected for initial tests. Experience with IDI diesel combustion systems suggests that this timing plan can then be retalned over the load range for initial tests. With this timing plan, the system was, therefore, fully evaluated over the load range at the 'key' speeds using D2 fuel. Alternative timing plans were then examined to enable the optimum fuel economy requirements and the trade-off to be assessed.

For the alternative fuels, each was initially examined at the same timing plan 1dentified for initial tests w1th D2 fuel and then at alternative tining plans to achleve the required objectives.

\section{DIESEL COMBUSTION SYSTEM}

The Initial timing plans utilized for D2 operation with this system were defined from Ricardo experlence with the engine using European specification diesel fuel. Alternative timing plano 
were then examined to define the D2 optimum for economy and enable trade-offs to be assessed. Since at the outset of this phase of the programme, it was anticlpated that the DI dlesel would be less tolerant than the IDI, inttlal tining requirements were assessed for each alternative fuel in a simflar fashion to that infially adopted for the IDI diesel. Alternative timing plans were then examined.

\section{SIIDI COMBUSTION SYSTEM}

The presence of two prime variables (injection and spark (iming) with this combustion system necessitated the adoption of a different 'optimlzation' procedure. Experlence indicated that timing responses at a high load factor at each speed could be used as an intital guldeline for operation over the load range. For such responses a series of spark timing swings were conducted at various infection timings. From these results it was possible to select an inttial 'opt imum' by the same criteria as used for the IDI diesel. Using these timing plans, inttial data was then acquired over the load range at the selected speeds. Problems encountered with this system precluded examining the SIIDI system with alternative timing plans to those detalled above.

\section{TEXACO TCCS COMBUSTION SYSTEM}

This combustion system alone during this programme differed in that the inttlal 'optimum' timing to be used as a starting point for tests was not determined as part of the programe. Having accorded this engine much development effort the manufacturers, White Engines Inc., were able to give guldance as to Inttial timing plans to be adopted for each fuel. A pollcy was adopted with this englne whereby the multi-strike spark was initlated some $3-5^{\circ}$ crank angle prior to the start of injection and maintained to the end of injection or for 25 crank degrees wh1chever was the shorter. Early initiation of the spark was recommended by iexaco for minimizing $\overline{\mathrm{HC}}$ emissions and avoiding detonation. Retard of the spark into the injection period to introduce a degree of fuel premixing was briefly evaluated, however, with the highest octane fuel (naphtha) addressed within the programme. The 1imitation of $23^{\circ}$ crank angle for the duration of the spark represents a practical 11mitation 1mposed by Echlin, the manufacturer of the ignition system.

Using this ignition timing strategy, alternative injection timing plans for each fuel to those recommended by White Englnes for Initial tests were examined to assess 1ndividual optima for economy and trade-offs.

\section{MAN FM COMBUSTION SYSTEM}

The procedure adopted for this combustion system was again different, characterized primarily by the need to optimize the timing of the injection and the spark for each individual operating point across the load range for each fuel. Experience with this type of combustion system in the past forewarned of differences in timing requirement across the load range, and this experience also directed the 'optimization' procedures, again with two prime

varlables, which were adopted. This initially required setting applied load to the desired point on the load range with the end of injection and the start of ignition maintained colncident at a relatively advanced timing. Injection and ignition were then retarded until maximum brake load (1ndicating optimum economy at fixed fuelling level) was observed. The fuel injection timing was then set to just before this point and the ignition tring trimmed for any further gains elther in brake load or combustion smoothness or stability. By this procedure the system was fully optimized for fuel economy with due regard to minimizing NOx and detonation.

To assess trade-off Implications, injection and spark were varied within a matrix bounded by the limits of operability. Owing to the time-scale involved with this type of testing, evaluation was limited to selected points over the load range at the two 'key' speeds.

Throughout the previously discussed test strategles for each combustion system within Task 3, the extent to which alternative timing plans were examined was prinarily controlled by the intention of defining minimum fuel consumption. At no point during the programme was the combugtion sufflcienty retarded to address the low NO $x$ engine compatible with current or future US legislation.

\section{ENGINE TEST BENCH AND INSTRUMENTATION}

Although certaln decisions previously discussed (see Test Engines, section 6) complicated the selection of englnes evaluated during both testing phases of this programme and increased the number of different test benches which had to be utilized, a high degree of commonality was malntalned between test benches.

Al1 test Installations were equipped with conventional $\mathrm{DC}$ electric dynamometers, enabling the measurement of motoring friction losses during the fundamental study. Each test bench was fully equipped with cooling circults for the automatic control of water and o1l temperatures. Intake alr temperatures were not specifically controlled but wide variation from the typlcal $20^{\circ} \overline{\mathrm{C}}$ was not experienced. Instrumentation was provided for the following main parameters:-

Dynamic Infection - Ricardo Instrumented infectors Tining

Cylinder Pressure - K1stler 6121 callbrated pressure and Start of

Pressure Rise transducer

Engine Speed

Exhaust Smoke

Fue1 Flow

Air Flow
- Toothed wheel and pick-up

- Bosch sample pump and comparator

- Calibrated volume and stop watch

- Cussons Ricardo viscous flow air meter 


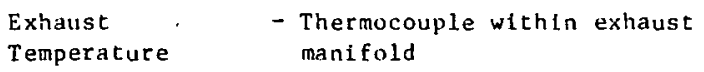

Other relevant temperatures and pressures were recorded as requilred.

Gaseous emissions were recorded by the following equipment :-

HC RATFISCII R35 Heated Flame Ionization Detector (FID) with heated filter and sampling system held at a controlled temperature of $180^{\circ} \mathrm{C}$.

Nox Thermoelectron Chemiluintnescent Analyser with heated sampling system controlled to $180^{\circ} \mathrm{C}$.

Co Cussons Ricardo Non-Dispersive Infra-Red (NDIR) analyser.

Exhaust particulates were measured with a Ricardo portable dilution tunnel, flow of exhaust to the tunnel belng regulated to prevent the tunnel temperature from exceeding $52^{\circ} \mathrm{C}$. Samples were collected on whatinan GF/A (glass fibre) papers.

A special fuel handling system was employed for all englnes in order to avoid problems with vaporization of the lighter fractions in the naphtha blended fuels. This sycem, shown in Appendix 2, pressurlzed the fuel infection pump feed and return lines and included a fuel cooler and vapour separator in the return line. Fuel pressures were maintalned at $103 \mathrm{kPa}$ (15ps1) and $172 \mathrm{kPa}$ (25psi) at the pump inlet and outlet respectively.

Although an important consideration in an alternative fuels programme, engine. noise measurements were not made throughour the programme owing to contract limitations. Subjective noise was, however, monitored.

\section{ANALYSIS OF RESULTS}

\section{ANALYSIS CONSIDERATIONS}

Before discussing the main analysis procedures adooted throughout the programme, two important features require describing in detall. These are the variation from measured friction assumed for certain combustion systems during analysis, and the cholce of minimum fuel consumption as the basis for comparison.

Regarding the first of these, it is readily apparent that when comparing the behaviour of several fundamentally different combustion systems, comparisons must be made between the "brake" results since the friction levels associated with each system are an inherent feature of the overall parkage. Th1s is particularly important for the stratified charge systems where lower compression ratios are utilized and friction advantages relative to the diesel englne are apparent, enabling scope for brake specific fuel consumption (BSFC) benefits independent of indicated combustion efficiency relationships.

However when (as here) a variety of combustion systems are evaluated on a common basic research engine, or when comparing results from single and inulticylinder engines, friction levels as measured need to be carefully reviewed. If from this it is consldered that a combustion system has been evaluated with a non-representative friction level, this can be accounted for during analysis.

Figure 6 shows motoring loss friction levels ineasured for each combustion syster as tested during the fundamental study. It was decided that in order to compare systems, the motoring loss friction levels assumed for analysis would be those expected from 4 cylinder c.2-2.5 litre versions of, each combustion syster. By this approach the DI diesel and the Texaco TCCS were tested with representative motoring loss friction levels while the other chree systems evaluated in single cylinder form each required the assumption of a suttable level.

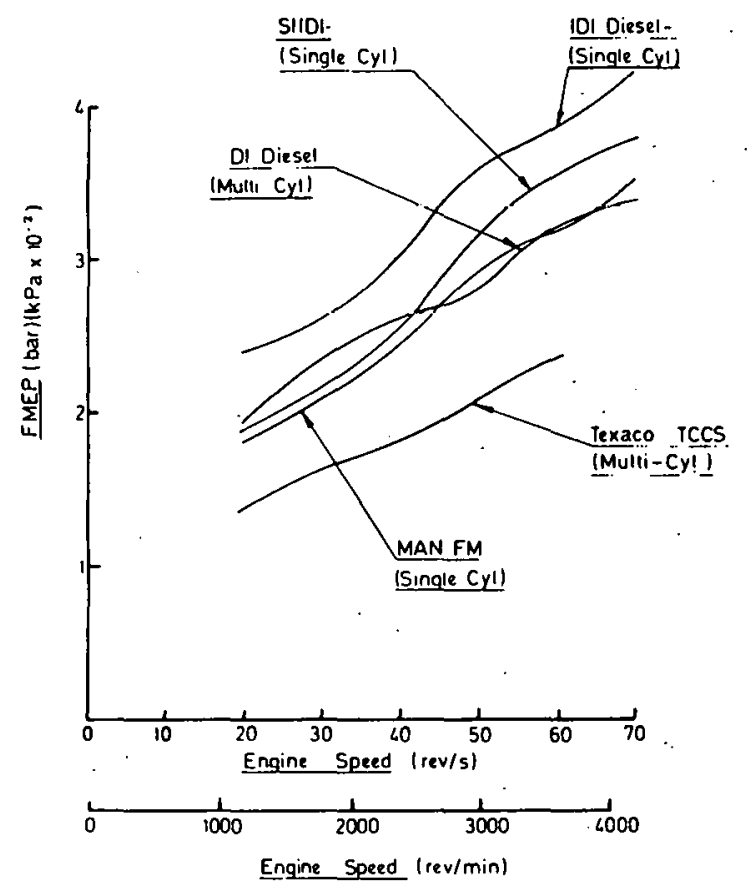

FIGURE 6 - MEASURED MOTORING LOSS FRICTION CHARACTERISTICS MULTI \& SINGLE CYLINDER ENGINES - FUNDAMENTAL STUDY 


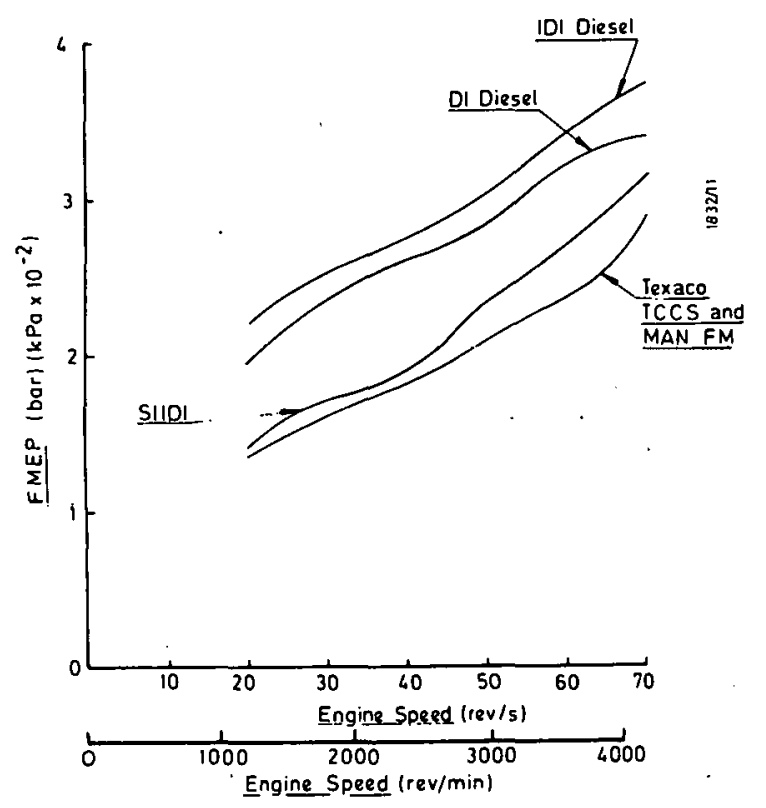

FIGURE 7 - REPRESENTATIVE MULTICYLINDER MOTORING LOSS FRICIIUN CHARACTERISTICS FOR ENGINES OF C.2-2.5 LITRES CAPACITY IN FOUR CYLINDERS

Figure 7 shows the motoring loss frtction levels assumed for the results as presented in this report. These levels were asslgned as tollows:-

IDI DIESEL COMBUSTION SYSTEM - This is now such a common light duty combustion system that a wealth of data is available (11) recording motoring loss friction levels as measured on such systems. From this data a band was constructed of results from 4 cyllnder c.2-2.5 litre units, and the mean of this band adopted for this work.

MAN FM COMBUSTION SYSTEM - Results were avallable from a previously tested 4 cylinder, 1.8 litre 14:1 compression ratio MAN FM system. Motoring loss friction levels from this englne were seen to be slightly higher than the Texaco TCCS tested during this programme. If, however, this multicylinder MAN FM data is adjusted to account for the higher compression ratio (well proven empirically derived friction calculations are avallable) then the resultant curve is substantially the same as that fot the Texarn TCC.S. This is as would be expected, both systems beling open chamber with similar compression ratios and swirl inducing inlet ports operating at similar cylinder pressures. The motoring loss friction level asumed for the FM combustion system was therefore as for the TCCS, but extrapolated to account for the higher rated speed.

SIIDI COMBUSTION SYSTEM - This combustion system again being low compression rat lo and subject to low cylinder pressures would in practice employ the same "gasoline" type crankshaft and bearings as the FM and TCCS systems above, giving it substantially the same mechanical motoring losses. However, the use of a swirl chamber increases its pumping losses and hence its measured motoring losses. This difference is due entirely to combustion chamber. design and can be quantifled as the difference observed between the SILDI and FM combustion systems as tested during this programme where both were evaluated on the same basic engine. For analysis purposes this difference was used in order to place the assumed 4 cylinder SIIDI curve above the FM/TCCS curve already discussed.

As a result of this approach, the motoring friction loss curves produced are characteristic of the relationships expected between the individual combustion systems and are, therefore, sultable for analysis within this programme.

Regarding the adoption of operation under conditions of minimim filal. ronslimption as the basis for comparison of combinations of engine and fuel, the objectives of the Fundamental Study (Task 3) should be remembered (see section 3 - Objectives). To satisfy these objectives, it was necessary to employ a method of analysis enabling the fundamental operating characteristics of each fuel/engine comblnation to be established. The use of minimul consumption as the basis for comparison effectively satisfles the Task objectives since it precludes compromising the operation of the engine/fuel combination as would be the case for example if a given low NOx level had been addressed. It is realised that ultimately the latter requires examination for a full understanding.

Apart from these two main considerations a third aspect of the analysis which should be discussed is tlie cliulce uf uilis employed for oonotderation of the gaseous emissions. In this case the prime objective was to satisfy the alms of the programme In the best possible way. Consideration was also given however to those who wish to compare with uclier dala. In selectling units to oatiofy thooo objectives the cholce can be logically limited to specific gravimetric units $(\mathrm{g} / \mathrm{kW} \cdot \mathrm{h})$ or volumetric units (ppm).

In choosing between these to satisfy the prime project objective the following points were considered.

In adopting a volumerric appruach lo aualysls, Lle main problem is that differences in throughput between systems arc not accounced fur. White such differences result from the throttling of intake alr, exhaust gas recirculation or boosting, the use of such ulills wuld nut be acceptable. With thio programme this is not the case, any differences in enroughpur resuleling fiulu silylic differences in swept volume and breathing capabilities. Moreover, it is known that the volumetric emissions from a given combustion syster generally characterize that syster, such that increasing or decreasing combustion chamber size (within limits) will not signiflcantly alter emissions patterns. This leaves the small differences in volumetric efficiency between systems as the remaining drawback in the use of $\mathrm{ppm}$.

The major drawback with the use of $g / k W \cdot h$ is the 
behaviour of results calculated thus in approaching Infinity at light load, although this effect is tolerated with the commonly expressed specific fuel consumption. This problem exacerbates, for example, the sharply rising HC response at light load of the open chamber stratified charge engine. It was consldered that for this programme the potentlal loss of light load information would not have been acceptable, thus biasing the final selection of units towards ppm.

This choice is not incompatible with the secondary consideration since within the Industry both sets of units.are widely used and therefore no cholce would satisfy the requirement of all readers. However experience Indicates that amongst workers with $11 \mathrm{ght}$ duty, unthrottled combustion systems the use of volumetric presentation is widespread. For those readers who wish to compare data in specific gravimetric terms, Appendix 3 should be referred to.

By definition, particulates must be expressed in gravimetric terms. In this case, $g / h / 1$ (of swept volume) were utilized to highlight the fundamental differences between combustion systems.

\section{ANALYSIS PROCEDURES}

Different analysis strategies were adopted for Tasks 2 and 3 , each being intended to sult the structure of the programme and present the data in an appropriate fashion.

It has already been stated that Task 2 (the multicylinder screening tests) covered two combustion systems (IDI and DI diesel) and two matn fuel variables (volatility and ignition quality) and only involved testing at standard fuel pump settings. Data has, therefore, been analysed and is presented in a way to best demonstrate comparisons between the combustion systems, and between fuels within each set. An analysis procedure was adopted whereby for each fuel the behaviour across the load range of certain variables - brake specific fuel consumption (BSFC), brake specific energy consumption (BSEC), HC, NOX, CO - was compared with the behaviour when operating on the "parent fuel", this being taken as the $D 2$ reference fuel. At all loads, the level of each variable on D2 was taken as unity enabling results to be presented on a truly proportional comparative basis. ruel consumption was analysed on an energy and on a mass basis even though differences in calorific values between the fuels were relatively small. Th1s allows for greater flexibllity in interpreting the results and dispels any doubt concerning the impact of differences in calorific value. Consumption results for this Task are discussed in energy terms within the maln body of the report but gravimetric results are also presented to enable comparisons with Task 3.

Bosch smoke data was not analysed on the same relative basis owling to the non-1inear nature of the relationsh1p between Bosch smoke units and carbon concentration.

Further analysis has enabled the presentation of smoke limited brake mean effective pressure (BMEP) and ignition delay period information for each combustion system and fuel combination.

Task 3 (Fundamental Study) data was analysed using an alternative strategy approprlate to the task objectives. It has already been stated that during this task a range of injection and/or ignition timing settings were covered for each comblnation of combustion system and fuel, the approach being modifled for each combustion syster as appropriate. From the test work w1th the IDI and DI dlesels and the Texaco TCCS combustion system, sets of load range curves were generated covering the range of injection timings examined. These results were used In order to construct timing response plots (at discrete intervals across the load range for each of the key speeds) for gaseous emissions, particulates, exhaust smoke and fuel consumption. With the responses available it was possible to select an injection timing plan from within the range covered, enabling synthesis of minimum BSFC loops together with the appropriate gaseous, particulate and smoke emissions. This approach was not necessary with the - MAN FM and SIIDI combustion systems owing to the test strategles adopted as previously discussed (see Section 8 ). In these cases, the load range curve data as observed was utilized.

The timing schedules employed for each combustion system at the key speeds are detalled in Appendix 5 . It should be noted that during this analysis, the timing plans extracted were not compromised to sult the mechanical limitations of any current fuel injection pump. Overall, they are presumed to be compatible with future developments in electronic controls.

As necessary, these load range curves were then modified and re-plotted, in order to allow the representative friction levels to be incorporated. The resulting curves form the basis for comparisons and are those presented in this report. Fuel consumption curves were also re-plotted in an Indicated form in order to facilitate comparisons of combustion efficiency, and in energy terms in order to eliminate any calorific value effects between fuels. Since, however, the small calorific differences do not cause any significant rodification of trends between fuels, comparisons have been presented and discussed in the main body of the report in the more famlliar BSFC terms.

Further analysis included evaluation of peak BMEP across the speed range for each combination of combustion system and fuel in order to compare torque potential. Also analysed were trade-off effects with respect of NOx, HC, particulates and BSFC Ignition delay behaviour for the diesel combustion systems, peak cylinder pressures and rates of pressure rise observed and the ability to start and subsequently Idle.

\section{RESULTS AND OBSERVATIONS - MULTICYLINDER DIESEL SCREENING TESTS - (TASK 2)}

When reviewing the results from these Task 2 and the later Task 3 tests it should be remembered that only one example of each combustion system type was evaluated during this programme. Although in the 
broadest sense comparisons made are considered valid the posstbility of some englne speciflc effects should not be ignored.

In this section results are presented from the IDI and DI multicylinder diesel engline screening rests. For both engines the baseline fuel was PhIllips D2 reference fuel. The IDI economy and gaseous emlssions results on this fuel were considered representative of the combustion system, rated power beling close to the spectfied production rating, and enissions results typical for European optinization. For the DI engine, the baseline results were difficult to judge as typical owing to the lack of similar systems with which to compare. However the englne lised, although not having reached a definitive state of development, was considered to have combustion performance, etc. compatible with ine objectives of che prugrame. Daselfiti fus aoneumption onct gasanis enfssions maps for hath systems operating on $\mathrm{D} 2$ are shown in Appendices $4 \mathrm{a}$ and $4 \mathrm{~b}$. (IDI and DI respectively).

In order to simplify the body. of this report, results from this task are presented in two ways. Complete data, Judged to be too voluminous for inclusion in the text, has been presented separately in Append $x 4$ and should be referred to In order to support the written detalled observations. With the text, data is presented in a simplified form to enable the major impact of the alternative fuels with respect to D2 to be ascertalned.

These simplified curves comprise all test data obtained over the speed range of $20-70 \mathrm{rev} / \mathrm{s}$. (1200 - 4200. rev/min) for each test engine.

A11 curves are presented in such a way as to enable rapid appreclation of differences between the two combustion systems (IDI and DI diesel) and the two individual fuel groups (varying ignition quality and volat111ty).

The following results and observations are presented In sections addressing the individual parameters considered as follows:-

FUEL CONSUMPTION

In this section, economy is compared on a brake specific energy basis (BSEC). Speciflc gravimetric fuel consumption results (BSFC) are supplied however In Append $1 \times 4 \mathrm{c}$.

Regarding fuel consumption, Figure 8, it will be seen that the alternative fuels examined allow ilttle scope for improving the consumption relative to that observed w1th the reference D2 with penalties of up to approximately $5 \%$ beling observed. In the case of the IDI diesel, the fuel consumption was consistently higher with the lowest ignition quality fuel $(38 \mathrm{cN})$. For the DI diesel this was not the case and generally the highest ignition quality fuel ( $51 \mathrm{CN}$ ) returned the highest consumption. (See Appendix 4d). For each test speed in both combustion systems, the higher fuel consumption trends with both of the more volatile blends of diesel and naphtha were generally similar and did not significantly differentiate between efther fuel.
101 Diesel

DI Diesel
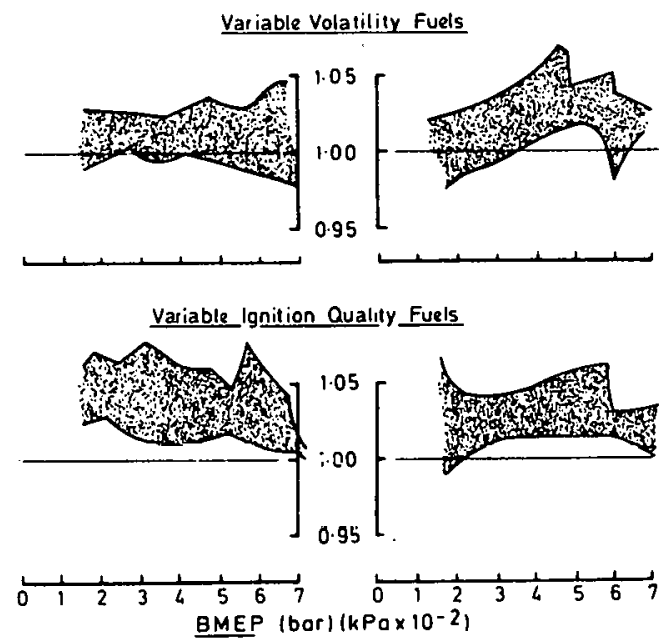

FIGURE 8 - ENVELOPES OF RELATIVE BRAKE SPECIFIC ENERGY CONSUMPTION (PHILLIPS D2 $=1.0)-A L L$ SPEEDS
These results may suggest that the start of pressure rise with the reference D2 fuel was closer to optimum In respect of economy. In this context, the ignition delay observed with the different ignition quality fuels followed expected trends. Relative to the D2 $(48 \mathrm{CN}$ ), the lowest ignition quality fuel ( 38 CN) Increased the delay perlod by typically $1-2^{\circ}$ crank whllst a reduction generally within the range of $0.5-2^{\circ}$ crank was noted with the highest ignition quality fuel $(51 \mathrm{CN})$. With fixed injection timing, these changes in delay perlod will influence the start of pressure rise and hence economy.

Furthermore, it should be noted that (with the exception of the fuel blend having the lowest naphtha proportion in the IDI tests) the blends of diesel and naphtha generally conferred a $1^{\circ}$ crank dynamic injection timing retard relative to D2 in both test englnes. This retard is presumed to be caused by fuel viscosity effects within the injection pump and may have further exacerbated the consumption perallies ubserved.

Additionally, the different physical nature (i.e. volatility, viscosity, etc.) of the diesel and naphtha blends with respect to the diesel fuel for which both combustion systems were developed will tend to influence the injection characteristics $1 . e$. penetration and spray characteristicis and, therefore, alter the patterns of fuel/air mixing. Particularly in the case of the DI engine, such phenomena may represent additional contributing factors towards the observed treits. 


\section{HC EMISSIONS}

Figure 9 shows that the more volatile blends of diesel and naphtha acted favourably in controlling HC emissions with the IDI combustion system. As an exception to this, the cases of large HC Increases observed with these fuels were due to the advent of secondary injections, and not direct fuel effects upon combustion. It may be reasoned that the reductions observed were due to the lighter fuel fractions of the blends promoting more efficlent fuel preparation during the combustion process. The degree of HC attenuation recorded was similar for both blends. (See Append Ix 4e). Prel ImInary inspection may imply that the simflar inftial $5 \%$ of the distillation characteristics (Table 3 ) provided a controlling influence. However, the approximate $1^{\circ}$ crank retard of dynamic 1njection timing observed with the blend having the highest proportion of naphtha may have prevented further HC reduction due to volatility alone. If this accounts for the similar trends observed, a further HC reduction may have been afforded by resetting the injection timing with this fuel.

With the DI diesel, the overall HC trends with the blends of diesel and naphtha did not demonstrate the reductions observed with the IDI engine. HC enlssions generally showed a slight increase at the lower test speeds and were broadly simllar, or marglnally lower, at the higher speeds. Ih1s would suggest counteractiuns to providing more effective fuel preparation during the combustion process. It is speculated that three factors may be involved. Firstly, the physlcal nature of the blends may have

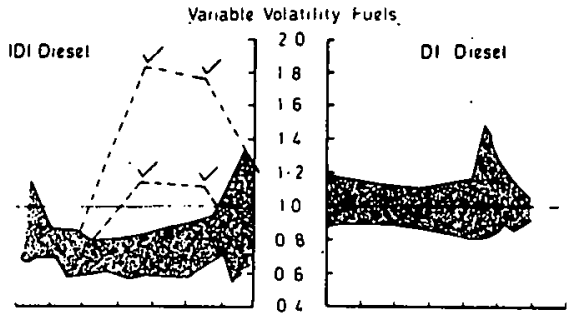

Yartable Ignition Ouality Fuels

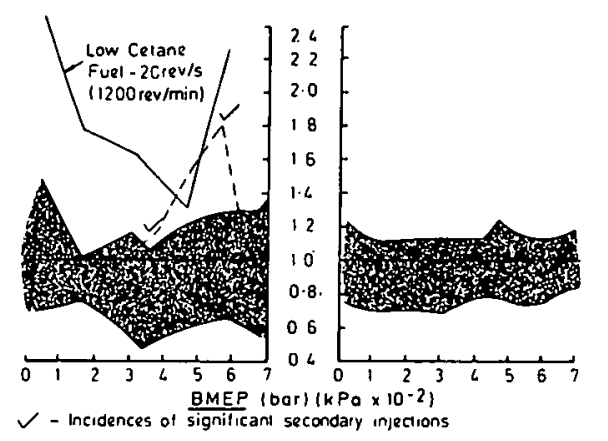

FIGURE 9 - ENVELOPES OF RELATIVE HC EMISSIONS (PHILLIPS D2 $=1.0$ ) - ALL SPEEDS
Influenced the fuel injection characteristics in a manner not comensurate with low HC emissions. Secondly, the general retard of dynamic injection tlining by $1^{\circ}$ crank with both blends may encourage higher HC emissions. The third and possibly most significant factor may be the contribution of the nozzle sac volume at the injector tip.

It is well documented (12) that the sac volume of conventional DI engine needle valve injectors contributes signiftcantly to overall HC emissions. This is particularly valid with small cylinder slzes, as with the englne tested here, since the sac volume becomes proportionally larger in comparison to the total quantity of fuel infected (13).

The ease with which fuel is released from the sac volume is enhanced by more volatile, less viscous fuels and higher HC enissions with such fuels have frequently been demonstrated for a given sac volume (12). In this fashion, the lighter blends of diesel and naphtha will have undoubtedly ralsed HC emissions despite the DI test engine being equipped with conventional nozzles. where the sac volume was ninimized $\left(0.55 \mathrm{~mm}^{3}\right)$.

In the context of $\mathrm{HC}$ emissions and uncontrolled infector volumes, it should be noted that similar problems do not occur with the IDI combustion system, typically using close clearance pintle infectors for nolse control.

It Is usually expected that by increasing 1gnition delay and retarding the start of combustion, low ignition quality fuels tend to Increase HC emlssions, particularly at the lighter loads (14). Under certain conditions, 1.e. Ilght load, high speed, inciplent or total misfiring can occur further increasing HC penalties. For both combustion systems tested, but particularly with the $D I$ engine, significant HC penalties associated.with retarded combustion and regimes of misfire had been anticlpated with the lowest ignition quality diesel fuel $(38 \mathrm{CN})$. Except for the IDI system operating at low speed, the anticipated impact was not evident, with HC emissions overall being broadly similar or somewhat reduced, relative to operation with the D2. These results were supported by the observed lack of any misfire regimes and, in addition, possibly reflect a trade-off belng introduced by the longer 1gnition delay $\left(1-2^{\circ}\right.$ crank angle for both combustion systems) between retarded combustion and the Increased proportion of cleaner, premlxed fuel.

The 1solated marked increase of HC emissions with the IDI system at low speed is not fully understood although corroborative results from the fundamental programme are discussed later. (See Results and Observations - Fundamental Programme - Section 12).

HC emissions followed expected trends in the DI system by being lower with the highest ignition quality diesel fuel ( $5 \mathrm{l} \mathrm{CN}$ ), clearly suggesting that the controlling factor was the more advanced combustion by $1-2^{\circ}$ crank angle. For the IDI erigine, the expected HC reduction was evident at the high test speeds but not at the lower speeds, where enlssions remalned broadly similar overall relative to operation with the D2. Th1s mixed response 18 
not readily interpreted although the reduced impact of the fuel ignition quality upon the degree of combustion advance In the IDI engine $\left(0.5-1^{\circ} \mathrm{crank}\right.$ angle) and the high mixing tates of the IDI system (potentally capable of imparting a degree of insensitivity) should be noted.

\section{NOX EMISSIONS}

NOx results are shown in Figure 10 (also Appendix 4f). The appreclable Nox reduction observed in the DI combustion system with the blends of diesel and naphtha is supported by the dynamic injectlon retard of about $1^{\circ}$ crank angle related to the fuel viscosity influence within the pump. The NOx reduction noted with the IDI englne when using the blend having the highest naphtha proportion may also be related to the recorded general retard of dynainic injection timing. The similar NOx reduction observed in the ínf with the other blend cannot however be supported by injection timing trends and the reasons for the Nox reduction are not fully understood. In this context, previous work in the field has recorded that for equivalent ignition quality more volatile fuels suppress NOx enissions in IDI diesels (15). In these cases it was speculated that improving fuel preparation owing to higher volatility, Increased combustion rate and reduced residence time with oxygen for Nox formation. 'This may account for the overall Nox reductions observed in the IDI programme although corroborative support is not supplied from the fundamental programme when comparing NOx emissions between diesel and broadcut fuels of equivalent ignition quality.

101 Diesel

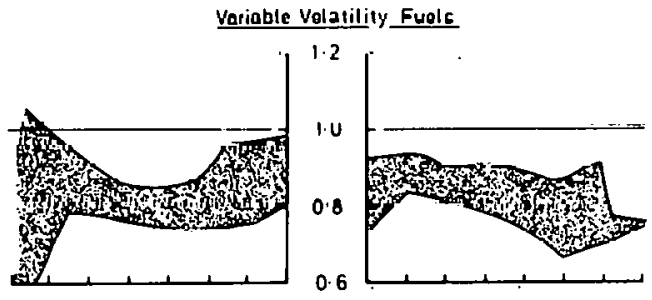

Yariable Innition Quality. Fưels
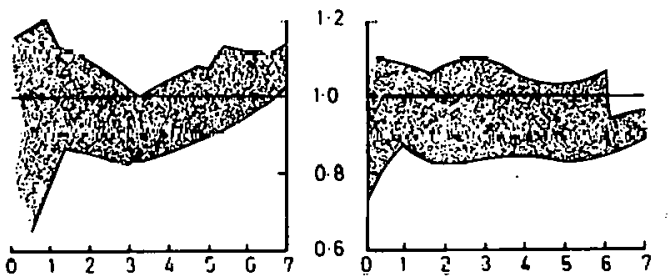

BMEP (bar) (kPa $\left.\times 10^{-2}\right)$

FIGURE 10 - ENVELOPES OF RELATIVE NOX FMISSIONS (PHIJIJPS D2 = 1.0 ) - ALL SPEEDS
In relaxing ignition quality at flxed injection $t$ linling, peak cylinder pressures (and temperatures) are influenced. The magnitude and direction of any trend represents the net balance between longer ignition delay retarding combustion on the one hand and Increasing the rate of pressure rise on the other. Naturally, peak cylinder pressure may not be Increased if both factors equate. Peak cylinder pressures may also be influenced with higher ignition quality fuels by applying the reverse argument.

When varying ignition quality, previous workers have frequently relied on the peak pressure argument to explain NOx trends. The NOx results for both combustion systems obtalned during this programne with the variable ignition quality fuels were somewhat difficult to interpret, generally not reconcilable with the observed varlations in peak cyllnder pressure and, therelore, nót àcountable for by resort to the classical explanation. More Importantly, the systems tested appeared broadly tolerant to varlable ignition quality within the ranges exanined, since Nox emissions were not cypically increased but overall remalned generally similar to, or lower, than operation with the D2.

\section{CO EMISSIONS}

Concerning $\mathrm{CO}$, it should first be remembered that both the combustion systems evaluated were unthrottled, and as such the co emissions are low and not problematical relative to current legislated standards. However, since such standards are 11able to change, the following observations are made. The CO trends obtalned from the IDI system, Figure 11 , largcly correlate well with observations made concerning the other variables discussed for this task. In the case of the diesel and naphtha blends co eulssious wete typlaally reduced throughout the operating range, 11 lustrated in Append $1 \times 4 \mathrm{~g}$. This supports the smoke and $H C$ trends and furtherer validato the oposulation eonoerning tha libhtor. fuet, fractions improving fuel preparation during the conbuotion procooo.

When varying ignition quality with the IDI, no general significant detrimental effects were observed except with the $38 \mathrm{CN}$ fuel where a significont increase was noted at lnw speed. This is supported by the HC obgcrvation previously discusged.

In the case of the DI system, Co trends were more

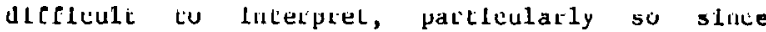
effects here are related to an already very low D2 baseline. Under such circumstances the proportional nethod of evaluation used gréatly èxággérátés sumáll absolute changes in 60 . In general however no serious detrimental eftects were observed.

\section{EXHAUST SMOKE}

Composite smoke data is shown in Figure 12. In the case of the IDI diesel, the more volatile blends of diesel and naphtha consistently reduced smoke output relative to corresponding results w1th the D2 (see Appendix 4h). Th1s implics a tendency for the lighter fuel fractions to induce more efficient premixing of fuel and alr during the delay pertod 


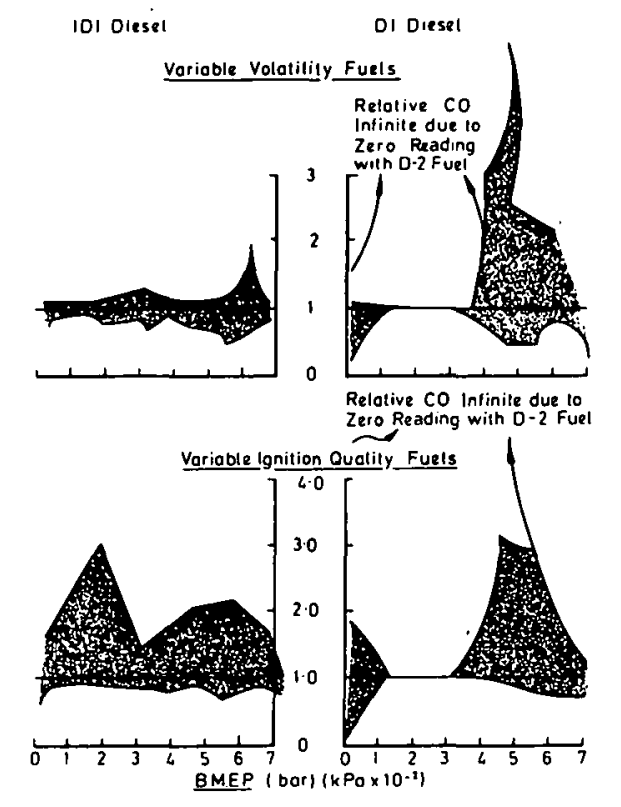

FIGURE 11 - ENVELOPES OF RELATIVE CO EMISSIONS (PHILLIPS D3 - 1.0) - ALL SPEEDS

and subsequent combustion phases. It should be noted that the incidences of secondary injections, held responsible for speciflc HC trends (see Figure 9) did not have a deleterious influence upon smoke emissions.

The observed reductions tended to be incremental as the proportion of naphtha was increased possibly implying that the distillation characterlstics between approximately 20 and $60 \%$ representer the controlling factor since other distillation characteristics were broadly similar (Table 3). However, for the IDI combustion system, the general $1^{\circ}$ crank angle dynamic injection retard recorded with the blend having the greater naphtha proportion should not be dismissed as a potential contributor to the moke trends observed between the blends:

Additionally, the lower aromatic content of both the diesel/naphtha blends will have assisted in controlling smoke output relative to D2 (1). Conversely, the diesel and naphtha blends did not confer a general smoke reduction relative to operation with D2 in the DI programme and no generalized trend was observed. These fuels however did appear to influence adversely smoke at the higher speeds and loads. At the lower test speeds, smoke patterns over the load range were sinilar to the corresponding D2 data. For the DI combustion system, the dyuante Infection retard of about $1^{\text {n }}$ crank angle generally observed with the diesel and naphtha blends will have been one of the factors contributing to increased smoke. Once again, the different phygical nature of the blended fuels will influence infection characteristics and may discourage efficient overall fuel/air mixing and increase sinoke. In this context, it should be noted that Injection characteristics will also be influenced with the IDI combustion system. However, this need not have an adverse influence since with higher mlxing rates, the IDI compared with the DI englne is less reliant upon the spray pattern as dictated by the fuel and fuel injection equipment for efflitent fuel/atr mixing and low smoke.

Ignition delay has frequently been correlated with snoke levels, particularly in DI engines (l). It has been argued that increasing ignition delay encourages a greater proportion of the infected fuel to be burnt in a premixed state, this being intrinstcally less smoky than droplet diffusion burning thus enabling smoke reductions to be achieved. This was demonstrated when comparing the DI engline results from the $51 \mathrm{CN}$ diesel fuel with the D2 rated at $48 \mathrm{CN}$ (Append $1 \times 4 \mathrm{~h}$ ). In this case, an appreclable increase in smoke was generally apparent whilst 1 gnition delay was reduced by $1-2^{\circ}$ crank angle. Supporting data was not provided with the IDI syster, where smoke levels were generally not significantly influenced adversely despite Ignition delay beling reduced by $0.5-1^{\circ}$ crank angle wh the higher ignition quality fuel. The narrower influence upon Ignition delay may be significant in this case.

With both combustion systems, exhaust smoke was generally not influenced by the lowest Ignition quality diesel fuel evaluated ( $38 \mathrm{CN})$ despite ignition delay being increased by $1-2^{\circ}$ crank. Relative to the corresponding data obtalned with the

$$
\text { i.] Alternative Fuels Phillips } \mathrm{D}-2
$$

101 Diesel DI Diesel
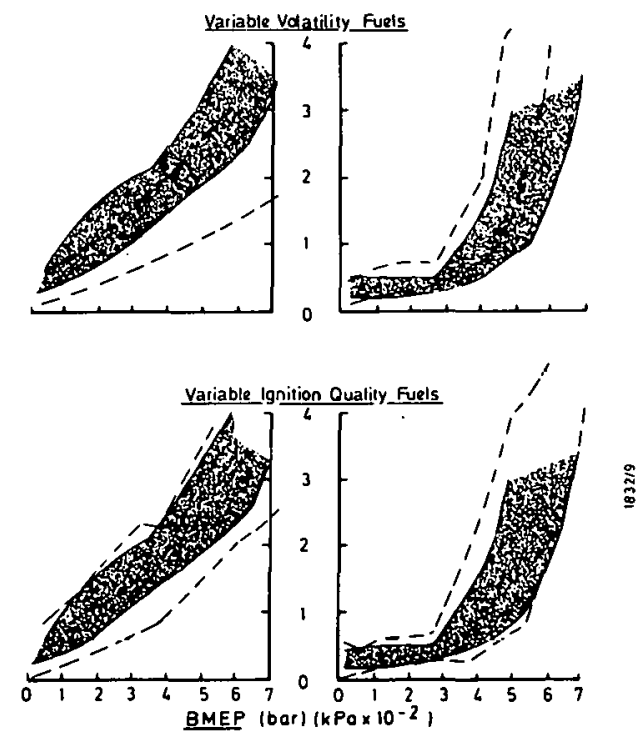

FIGURE 12 - ENVELOPES OF EXHAUST SMORE - ALL SPEEDS 
D2 the smoke patterns with

D2 the smoke patternstwith this low fgnttion qualtty fuel revealed little appreciable overall influence with the IDI engine, whilst in the DI engine smoke was marginally increased at the lower speeds but did not significantly change at the higher speeds. These trends do not agree with the Erequently quoted smoke and fuel ignition quality theory previously mentioned. The results obtained suggest that for the engines tested, a trade-off exists between the increased degree of prenlxed burning and the retarded start of combustion as a function of the longer ignition delay.

\section{SMOKE LIMITED BMEP}

Smoke Ilmlted BMip curves are shown in Figure 13. The differences that are shown between the fuels are largely compatible with the sinoke trends over the load range already discussed. With the blends of diesel and naphtha in the IDI tests, the small rated power inprovements within smoke lidits could not be achleved owing to the attalnment of practical exhaust temperature limits. This situation would have been exacerbated by the dynamic injection retard observed with one of the blended fuels. overall, the smoke limited BMEP curves show the IDI englne to be less fuel sensltive in the adverse sense than the DI engine, since only in the latter case was the smoke 11 mited BMEP curve penalized with alternative tuels to thillips $\mathrm{V} 2$.

- Phitlips 0.2

a $50 \%$ / $50 \%$ Diesel / Naphtha

- $66 \% 134 \%$ Oiesel / Naphtha

+ Phillps $0.2+0.12 \%$ IEL

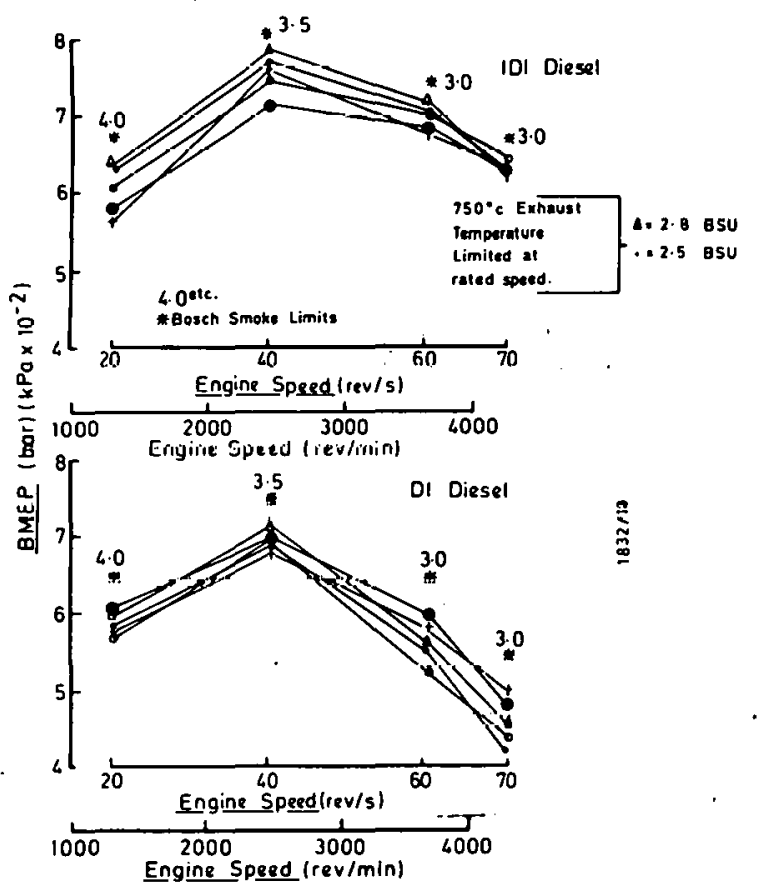

FIGURE 13 - COMPARISONS OF SMOKE LIMITED BMEP

\section{OPERATIONAL CONSIDERATIONS}

Throughout this task, no operabllity limits, 1.e. misfire, combustion instability etc., were encountered for any englne/fuel combination.

$$
\text { : }
$$

12. RESULTS AND OBSERVATIONS - FUNDAMENTAL PROGRAMME - (TASK 3)

In this section the results and observations for the fundamental study (Task 3) are presented. In presenting these results, four areas have been considered as follows:-

a) Fuel tolerance of individual combustion systems.

b) Operational considerations

c) Baseline comparisons of combustion systems.

d) Gaseous emissions trade-offs.

The fuel tolerances of individual combustion systems and the comparisons between the combustion systems are made from data with the combustion timing set for optimum BSFC. The appropriate injection and/or ignition timing plans to achleve this are shown in Appendix 5 for each syster. The Information obtalned at these tinings in respect of performance and emissions is referred to within the subsequent sections, where approprlate, as baseline engine data.

FUEL TOLERANCE OF INDIVIDUAL COMBUSTION SYSTEMS

Here, the fuel tolerances of each combustion system, using the baseline data obtained, are consldered in detall. For each combustion system, fuel consumption is discussed in mass terms, and not energy. For completeness, the equivalent energy spectelc consumption data is shown in Append1x 6 .

IDI DIESEL COMBUSTION SYSTEM (FIGURES 14,15,16) For this combuston system data has been presented showing D2 baseline information as a band of results rather than a single line. The drift in engine performance and the phllosophy behind the adoption of such presentation has been discussed in detall in the earlier 'Experimental Detalls' - section 8 of this report.

The performance (1ncluding corque potential) and elulablune characteriscles presented Lith this repurt are typical of the swirl chamber combustion system evaluated when considering operation on regular diesel iuel.

Fuel Consumpetion - At che lower cest speed of 25 rev/s (1500 rev/min) (Fig. 14) differences in consumption are readily apparent between fuels. At light load, all fuels except the naphtha demonstrated economy inferior to the D2 baseline, the worst belng the predominantly diesel broadcut, oome $10 \%$ higher. Around mid-loads the two broadcut fuels stand out alone showling economy $4-8 \%$ worse than D2. At full load differences are less apparent. 


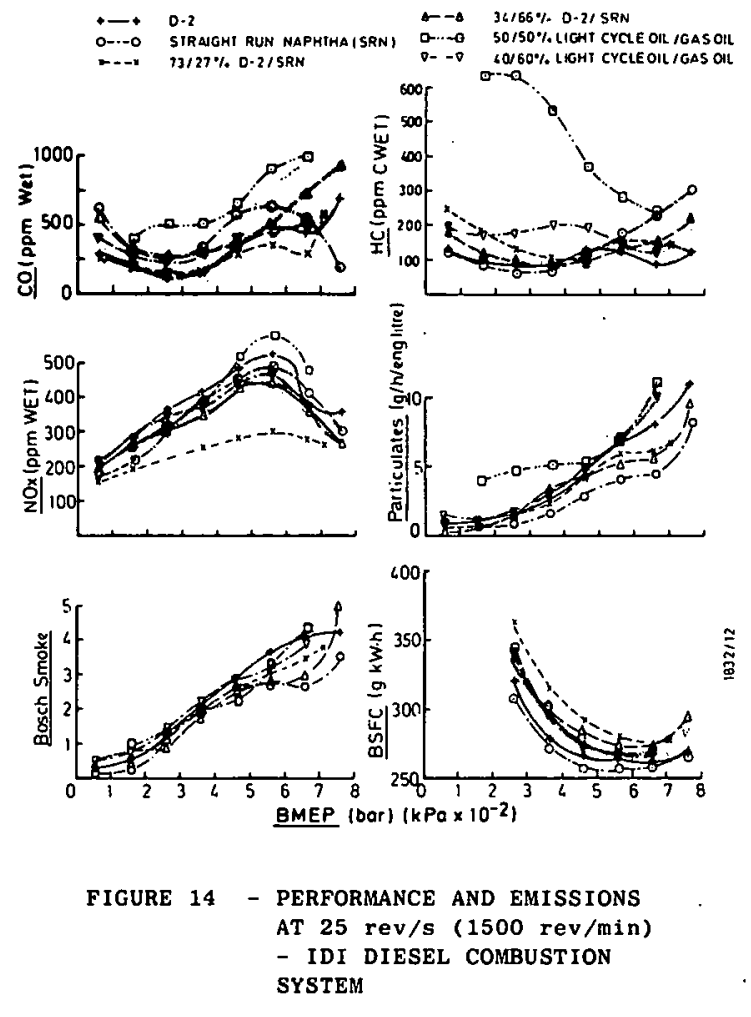

At $40 \mathrm{rev} / \mathrm{s}(2400 \mathrm{rev} / \mathrm{min})$ (Fig. 15) there is evidence of less variation between fuels, most overlaying the D2 band. However at light loads, which te should be remembered are fundamental to overall light duty economy, the broadcut fuels and the naphtha show increases of about $3-5 \%$ while at mid-load the higher ignition quality aromatic diesel fuel showed an increase of about $5 \%$.

Since the results as presented have been distilled from a greater number of tests at various injection timings in order to synthesize load range curves of minimum consumption at both test. speeds, it is Inherent that no further gains in economy would be possible with any of these fuels by simply modifylng injection timings to account for the different ignition delays. It is however possible that benefits would be avallable by detalled development of fuel injection equipment or combustion chamber design to suit a particular fuel. It is also worth considering that the fuel consumption penalties evident, particularly in the Important light load area with some of the fuels, may well be offset overall when the economics of producing lower specification fuels are considered.

The major anomaly with this combustion system is with the naphtha fuel at the lower test speed, this being the only case of fuel consumption superior to the D2 baseline. It is possible that at this lower speed, lower swirl rates and temperatures in the swlrl chamber become critlcal factors, allevtated by the higher volatility of the naphtha enabling an offseting of its low lgnition quality by encouraging rapld burning after ignition. This may imply that

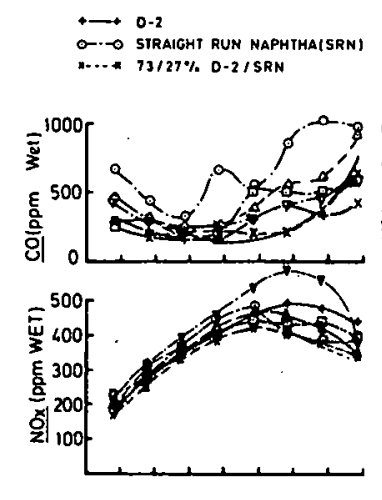

$\rightarrow 34 / 66 \% 0.2 /$ SRN

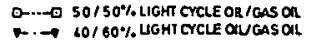

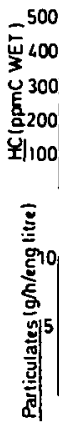

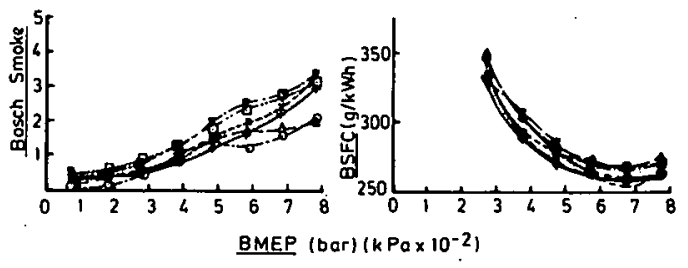

$\begin{array}{ll}\text { FIGURE } 15 \text { - PERFORMANCE AND EMISSIONS } \\ \\ \text { AT } 40 \mathrm{rev} / \mathrm{s}(2400 \mathrm{rev} / \mathrm{min}) \\ \\ - \text { IDI DIESEL COMBUSTION } \\ & \text { SYSTEM }\end{array}$

Increasing the swirl and/or compression ratio may help offset the economy penalties observed with the other fuels. Increased swirl would, of course, be detrimental to high speed economy and a sultable comproinse would need to be determined.

NOx Emissions - At the lower test speed of $25 \mathrm{rev} / \mathrm{s}$ (1500 rev/min) (Fig. 14) the alternative fuels did not generally demonstrate NOx levels higher than the D2 baseline. The only fuel to demonstrate a significant difference was the higher 1gnition quality broadcut although the benefits here can be largely attributed to the retarded tiring plan which was adopted for best economy (Appendix 5a).

At $40 \mathrm{rev} / \mathrm{s}(2400 \mathrm{rev} / \mathrm{min})$ (F1g. 15) NOx results with the alternative fuels are again similar to those with D2 although this time the higher ignition quality aromatic diesel fuel shows higher levels. Again this can be attributed to differences in infection timing, this being more advanced in order to minimize consumption. Closer analysis of the selected timing plan confirms that although a more retarded timing could have been adopted to minimize NOx with only a small fuel consumption penalty, the accompanying Increase in HC would have been 20-30\%.

HC Emissions - At both test speeds the HC levels showed a relatively high degree of tolerance to the large variation in fuel specification. At each speed however one fuel showed significant problems as follows:

At $25 \mathrm{rev} / \mathrm{s}$ (is $00 \mathrm{rev} / \mathrm{min}$ ) (F1g. 14) the low ignition quality alternative diesel fuel 
demonstrated an excessive HC problem, particularly at light loads. Although this may be related to the timing plan adopted to minimize fuel consumption the situation Ls unavoidable. Retarding the high load dynamic injection tioning by $3^{\circ}$ crank angle reduces high load HC enissions to levels competitive with D2, and indeed, reduces NOx with a fuel consumption penalty of only about $2.5 \%$. The use of such an injection timing down the load range is however precluded by the early onset of inisfire at loads below approximately 3.5 bar BMEP.

At $40 \mathrm{rev} / \mathrm{s}(2400 \mathrm{rev} / \mathrm{min})$ (F1g. 15) the naphtha demonstrates high HC levels, this being attributed to the low ignition quality of the fuel increasing the ignition delay perfod and retarding the start of combustion. In this context th should be noted from Append $1 x$ that the opt imum economy tining plan required for naphtha compared with D2 is not advanced pro rata to account for longer ignition delay as may have been anticlpated. In general this also applies to the other alternative fuels. The longer ignition delay and the high volatility of naphtha will further tend to increase fuel premixing. This carries over lean pockets of low ignition quality charge which resist successful combustion.

The absence of a similar overall impact upon $H C$ emissions at the lower test speed of $25 \mathrm{rev} / \mathrm{s}$ ( 1500 $\mathrm{rev} / \mathrm{min}$ ) with naphtha as fuel may suggest that the HC effects discussed above are offset by 1mproved mixing and combustion as a function of the higher volatility under the lower swirl rates and temperatures prevalent within the swirl chamber at l.ow speed.

Exhaust Smoke - At both test speeds little or no problems were evident with exhaust smoke. The higher volatility fuels, as observed during the multicylinder screening tests, again demonstrate a tendency to suppress smoke formation. With the alternative diesel fuels, however, it had been expected that their higher final bolling point and aromatic content would have caused increased smoke formation (1). That this was not evident is attributed to cleaner burning as a result of the higher degree of premix during the longer ignition de.lay period.

Particulate Emlssions - In general, the particulate levels respond as expected, 1.e. they reflect the domination of $\mathrm{HC}$ levels at light load where smoke levels are low, but become dominated by trends in smoke formation at higher loads. At both test speeds particulate output with the more volatile naphtha and broadcut fuels does not demonstrate signiflcant penalties relative to $\mathrm{D} 2$, and indeed at higher loads demonstrated reductions, this being primarily due to the aforementioned reduced smoke. The high $\mathrm{HC}$ response at $25 \mathrm{rev} / \mathrm{s}$ (1500 rev/min) (Fig. 14) with the low ignition quality aromatic diesel fuel did as expected and returned increased particulates.

CO Emissions - Emissions of co are in all cases low, as is expected for unthrottled diesel engine operation.

However, certain observations can st 111 be made even at these low levels. At the lower test speed (F1g. 14) the lower ignition quality aromatic diesel fuel shows somewhat increased $\mathrm{CO}$. Given that these fuel did not adversely influence smoke, these co trends are not fully understood. At the higher test speed (Fig. 15) those fuels causing an impact upon CO emissions are naphtha, at all loads, and the higher ignition quality alternative diesel fuel at high loads. The naphtha is somewhat difficult to explain, since the mechanism which led to a reduction lit smoke might well be expected to have reduced $\mathrm{CO}$.

Smoke Limited BMEP - Considering the wide variation in fuel specifications evaluated, the impact on avallable torque is relatively small. (Fig. 16) It should be noted here that the torque potential of this (and the other) combustion systems has been analysed in isolation from the load range curve data which user timing plans commensurate with maxioum economy. When examining torque potential across the speed range, the timing plan utilized was that required for maximized torque. In many cases this tining plan was compatible with an extrapolation of the maximum economy timing plans utilized across the load range at the key speeds. Although the naphtha and the predominantly naphtha broadcut blend produced torque curves comprable to the D2, the predominant1y D2 broadcut b1end showed a penalty of $3-6 \%$ across the speed range. The low ignition quality alternative diesel fuel did not greatly influence the smoke limited rating of this combustion system, but did reduce torque by about $3 \%$ at lower speeds. The higher ignition quality alternative diesel fuel also penalized low speed torque by up to $11 \%$.

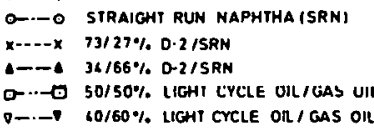

- 4.0 etc Bosch Smoke Limits

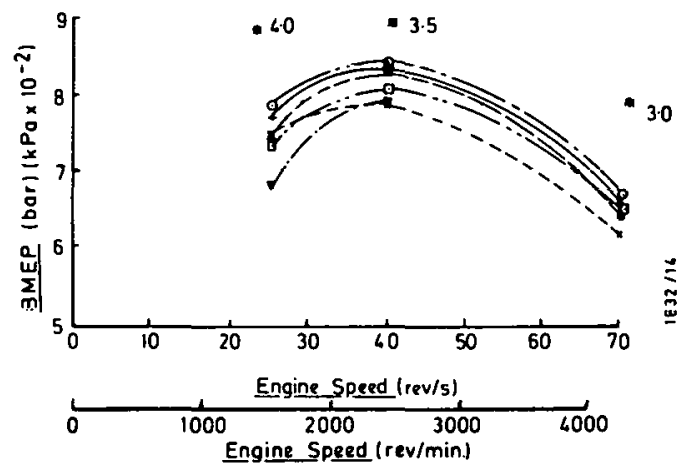

FIGURE 16 - SMOKE LIMITED BMEP CURVES IDI DIESEL COMBUSTION SYSTEM 
Problems which developed within the fuel injection equipinent at the end of the work, and not atcributable to the fuel itself, prevented this final fuel from being evaluated at rated speed in this engine.

DI DIESEL COMBUSTION SYSTEM (FIGURES $17,18,19$ ) With thls combustion systen severe instability was experlenced when operating with the predonlnantly naphtha broadcut hlend. This was evident as rapid variations in dynamic infection timing, fuelling level instabilities and an inability to malntatn constant loads or speed. This problem was attributed to vaporization of the naphtha fraction within the fuel pump. Although the fuel system incorporated the same pressurlzed handling procedure used successfully wth the other combustion systems the problem could not be overcome. Why this should have occurred was not understuod, al though the high pressure, minimut trapped volume speclalist fuel injection pump utllized on this engine alone during the programme may provide the key. This therefore precluded the testing of this fuel and, by 1mplication, naphtha, leaving only three fuels which were successfully evaluated.

Fuel Consumption - Fuel consumption generally shows a high degree of similarity between the fuels, the major effect being an increase of typically $4 \%$ relative to D2 with the low ignition quality alternative dlesel fuel at hoth rest spends, high load factors (Figures 17,18 ). This penalty could probably be overcome by spectific development of the combustion systen for this fuel.

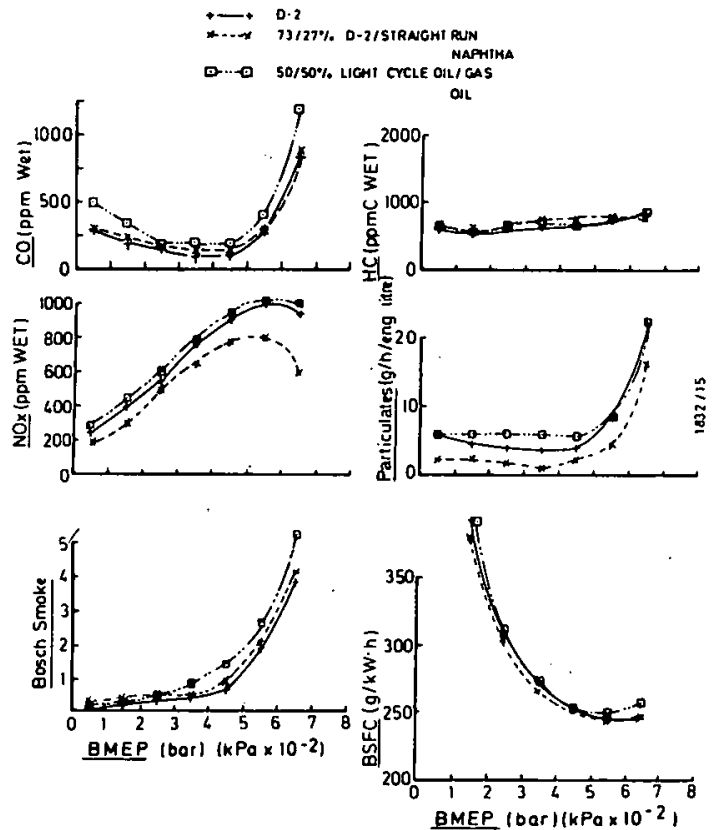

FIGURE 17 - PERFORMANCE AND EMISSIONS AT $25 \mathrm{rev} / \mathrm{s}(1500 \mathrm{rev} / \mathrm{min})$ DI DIESEL COMBUSTION SYSTEM
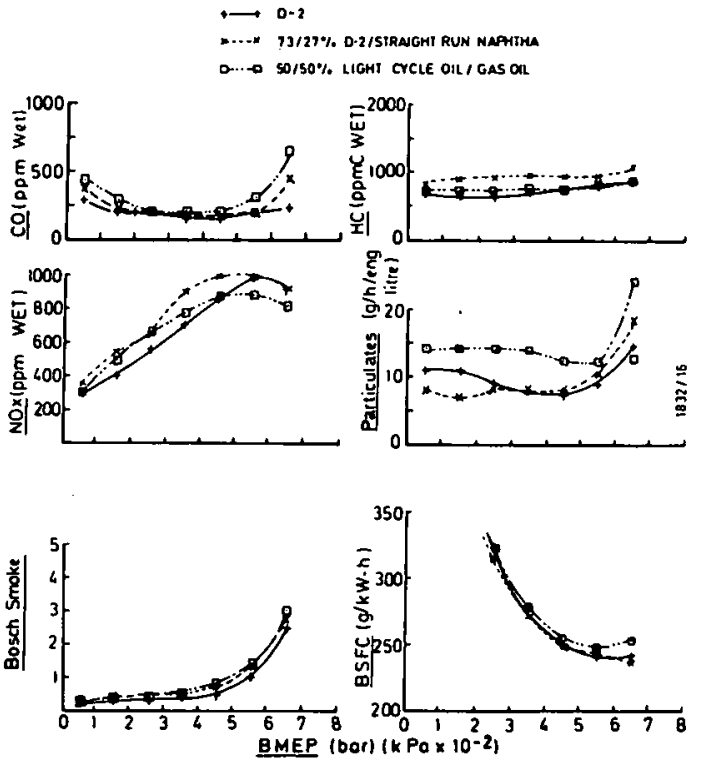

FIGURE 18 - PERFORMANCE AND EMISSIONS AT $40 \mathrm{rev} / \mathrm{s}$ (2400 rev/min) DI DIESEL COMBUSTION SYSTEM.

Nox Emissions - The main observation at the lower test speed (Fig. 17) is the reduction of NOx, particularly at high load, with the broadcut fuel, this beling primarily a result of the retarded timing plan required to achleve best economy (see Appendix 5b). At the higher test speed (Fig-18), this fuel shows Increased Nox levels relative to D2 although the timing plans were identical. Here the increase is attributed to Improved premixing of fuel during the Igntion delay period $(14,16)$.

HC Emissions - Emissions of HC can be seen to be largely tolerant to fuel spectflcation, the only significant effect being an increase of approximately $25 \%$ with the broadcut blend at 40 $\mathrm{rev} / \mathrm{s}$ (2400 rev/min) (Fig. 18). This is compatible with the clasic explanation of HC formation resulting from the late contribution of fuel from the nozzle sac volume, the effect being aggravated by more volatile fuels (12). That such a trend is not evident at the lower test speed may be due to high volatility, lmproving combustion under the lower swirl conditions in the combustion bowl offseting the deleterious contribution from the nozzle sac volume.

Exhaust Smoke - Exhaust smoke showed little response to the differences in fuel specification, the only significant effect being an increase at $25 \mathrm{rev} / \mathrm{s}$ ( $1500 \mathrm{rev} / \mathrm{mIn})(\mathrm{FIg} \cdot 17)$ with the alternative diesel fuel. This increase, from mid-load upwards, may be explained by inferior mixing of the fuel and air with the combination of less volatile fuel fractions, and lower combustion bowl swirl rates at this lower speed. Aromatic content is also known to correlate with smoke emissions (1). 
Particulate Emissions - The partlculates data shows significant differences between the fuels evaluated, this not appearling to be compatible with the overall lack of response by smoke and HC. The general pattern which is apparent shows that the more volatile fuels promote lower particulate output, particularly at lower loads, and $t$ is speculated that these fuels produce a species of HC less conduclve to particulate formation. Similar trends are not evident at the higher load factors wher? smoke output becomes the controlling factor.

Co Emissions - As with the previous combustion system, all fuels demonstrate the very low Co levels typical of unthrottled operation. Very little difference is apparent between fuels, the general relationship being fully compatible with the smoke trende and requiring no diecusolon.

Smoke Limited BMEY - The smoke I Imited BMEP curves TFlg. 195 are as would be expected from the observed smoke trends 1ndicating that performance levels similar to those with $\mathrm{D} 2$ are possible with the exception of a reduction of about $8 \%$ at low speed with the highly aromatic diesel fuel. This penalty is significant when it is considered that the light duty DI diesel, at 1 ts present state of development, is already at a disadvantage relative to the IDI diesel. However, this penalty may be overcome by spectfically directed developrent.
SIIDI COMBUSTION SYSTEM (FIGURES 20,21,22) - W1 th this combustion system, three of the fuels were evaluated. Of the fuels not evaluated, the naphthe was precluded owing to continual sooting of the sparking plug which prevented operation for periods sufficlently long to enable evaluation: Attempts were made to overcome this problem but it became apparent that sufficlent effort could not be afforded without Implicating the overall programme time-scale.

The highly aromatic alternative diesel fuel was also not evaluated owing to a number of mechanical problems which were expertenced with the basic engine during evaluation of this combustion system. The problens encountered were not fuel induced, but resulted in insufficlent time being avallable for operation with thio fuel.

Fuel Consumption - Fuel consumption trends with this corbustion system generally Indlcate fuel tolerance, with the maximum penalifes being within approximately $5 \%$ of the minimum consumptions recorded. The system appears to favour low 1gnition quality volatile fuel, particularly at the lower test speed (F1g. 20), this trend being in broad agrement with past experience (4). Conversely the data also Indicates, at the higher speed, worse consumption patterns with the relatively high Ignition quality predominantly D2 broadcut fuel. $\begin{array}{ll}+ & 0.2 \\ --* & 73 / 27 \% \text { 0.2/ SIRAIGMT RUN NAPHTHA }\end{array}$

O-..D 50/50\% LIGHI CrCLE OLL /GAS OIL

$4 \cdot 0$ ite

- BOSCH SMOKE LIMIIS

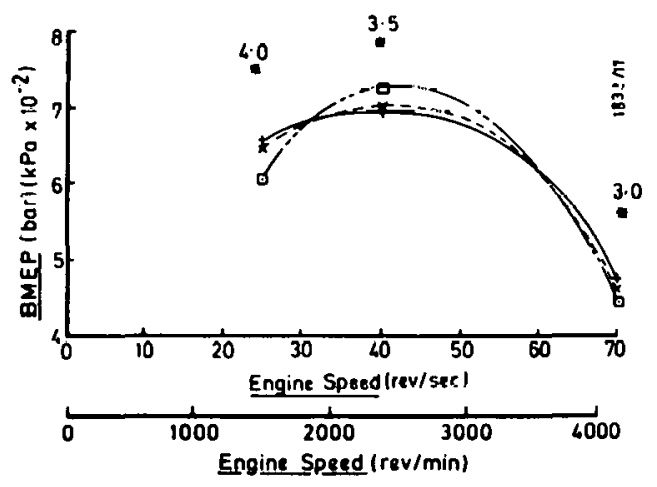

FIGURE 19 - SMOKE LIMITED BMEP CURVES DI DIESEL COMBUSTION SYSTEM

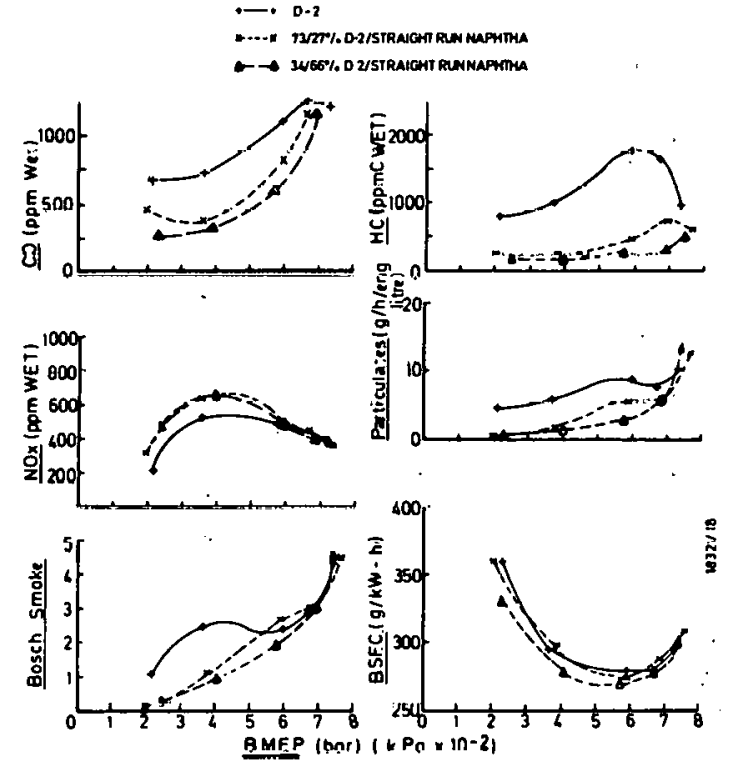

FIGURE 20 - PERFORMANCE AND EMISSIONS AT $25 \mathrm{rev} / \mathrm{s}$ ( $1500 \mathrm{rev} / \mathrm{min}$ ) SIIDI COMBUSTION SYSTEM 


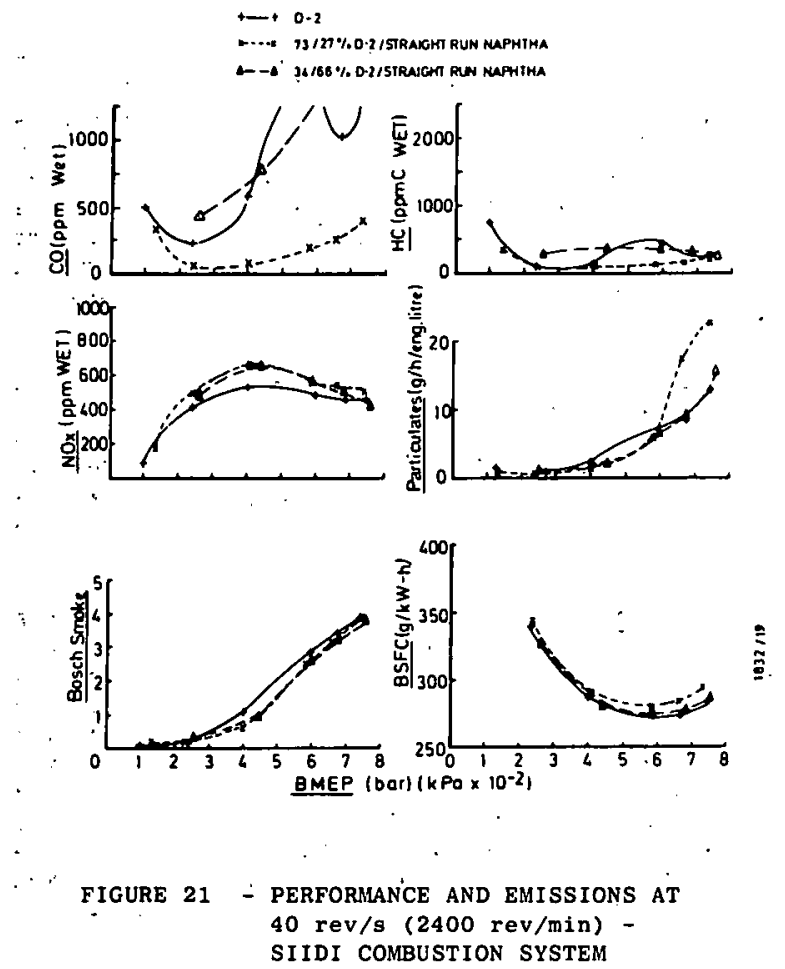

NOx Em1ssions - At both test speeds, minimum Nox was observed with the D2, both the broadcut fuels being nearly 1dentical to each other, but higher than the D2. These trends have been reported before (4) when it has been demonstrated that Nox 1 evels are closely related to fuel volatility. It is speculated that the oxygen avallability, required for Nox formation, is enhanced with the more volatile fuels. as such fuels are more readily dispersed within the chamber by evaporation.

HC Emissions - Previous work with a similar combustion system has indicated that high ignition quality fuels are generally conducive to lower $4 \mathrm{C}$ enissions (4). This is thought to be due to reaching the self ignition, teinperature of the fuel within the swirl chamber as the flame becomes established thus assisting combustion and reducing the probability of zones of unburnt fuel existing. This trend, although broadly apparent at the higher test speed (F1g. 21) is certainly not so at the lower speed (Fig. 20), where the D2 demonstrates a significant increase in HC. This however, in spite of having been rechecked to verify the effect is, based on previous experiments, (4) uncharacteristic for this type of combustion system and is attributed to the limited development effort accorded to the particular system examined.

Exhaust Smoke - The smoke trends show little response between fuels except in the case of the D2 results at light load, $25 \mathrm{rev} / \mathrm{s}(1500 \mathrm{rev} / \mathrm{m} 1 \mathrm{n}$ ) (Fig. 20). Previous experience again suggests that this is uncharacteristic for the system and may be related to the development status of the engine (4).
Particulate Emissions - Except for the high particulate response recorded w1th the D2 at 25 $\mathrm{rev} / \mathrm{s}$ ( $1500 \mathrm{rev} / \mathrm{min}$ ) (F1g. 20), which merely reflects the already discussed uncharacteristically high HC and smoke levels, the particulates recorded denionstrate very little tendency to differentiate between fuels. Those differences which are evident can generally be related to the $\mathrm{HC}$ and smoke responses w1th the exception of the predominantly D2 broadcut blend which shows a marked increase at high load, $40 \mathrm{rev} / \mathrm{s}(2400 \mathrm{rev} / \mathrm{min})$ (F1g. 21$)$ which is difficult to explain.

Co Emissions - At the lower test speed (Fig. 20), the CO results respond in sympathy with smoke output. At the higher test speed (F1g. 21), trends are not so well defined, although there is evidence that the combination of higher volatility and relatively high ignition quality with the predominanty dlesel broadcut fuel promote 1mproved fuel preparation and combustion resulting in the lowest $C O$. Why the other fuels show greatly increased $C O$ output not reflected in results with the other variables is not fully understood, but it should again be sald that the levels in question are all very low as is usual for unthrottled operation, and not considered problematical.

Smoke Limited BMEP - The smoke limited BMEP curves shown 1n Figure 22 demonstrate that at the two main test speeds of 25 and $40 \mathrm{rev} / \mathrm{s} \quad(1500$ and 2400 $\mathrm{rev} / \mathrm{min}$ ) comparable torque values were achieved over the speed range between all three fuels tested. However, at rat'ed speed, fuel effects were evident. With this conbustion system, rated speed (intended

$\longrightarrow 0.2$

- STRAIGHI RUN MaPHIHA (SRN)

T3/27\% 0-2/SRN

$4^{4-0}$ etc. Bosch Smoke Limits

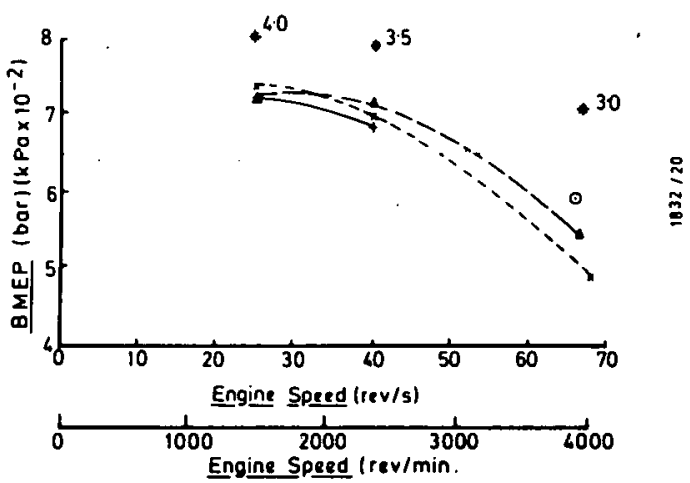

FIGURE 22 - SMOKE LIMITED BMEP CURVES SIIDI COMBUSTION SYSTEM 
to be $70 \mathrm{rev} / \mathrm{s}(4200 \mathrm{rev} / \min )$ was deflned by the onset of autoignition at the higher load factors causing loss of successful spark management of the combustion process. In this mode, running was generally unsatisfactory with unstable, erratic. combustion and incidences of detonation. To avold this and to restore spark zontrol necessitated significantly reducing the rated speed for D2 operation to below $50 \mathrm{rev} / \mathrm{s}(3000 \mathrm{rev} / \mathrm{m} / \mathrm{n})$. With the lower Ignition quality alternative fuels realistic rater speeds coult be achieved, as shown in Figure 22. At these rated speeds acceptable combustion conditions could be maintalned down to relatively light loads.

Note that with naphtha, operation at rated speed was achieved without the spark plug sooting problem which had been encountered at the lower speeds. At rated speed, the sinoke limited BMEP deinonstrates greatest torque with the most volatile fuels, this being another deinonstration of the tendency for volatile fuels to inhibit smoke formation, as noted elsewhere in this programse.

SPARK IGNITED DIRECT INJECTION (TEXACO TCCS) COMBUSTION SYSTEM (FIGURES 23,24,25) - Th1s

combustion system was successfully evaluated on the D2, naphtha and both intermediate broad cut fuels. The low ignition quality, aromatc diesel fuel was only tested at $25 \mathrm{rev} / \mathrm{s}(1500 \mathrm{rev} / \mathrm{mln})$, test work at the higher speed being precluded by fallure of the engine oll pump. Since this pump falled with very little test work left incomplete, and since the other fuels tested indlcated that the fundamental characteristics of the combustion system do not vary substantially between fuels or between the two test

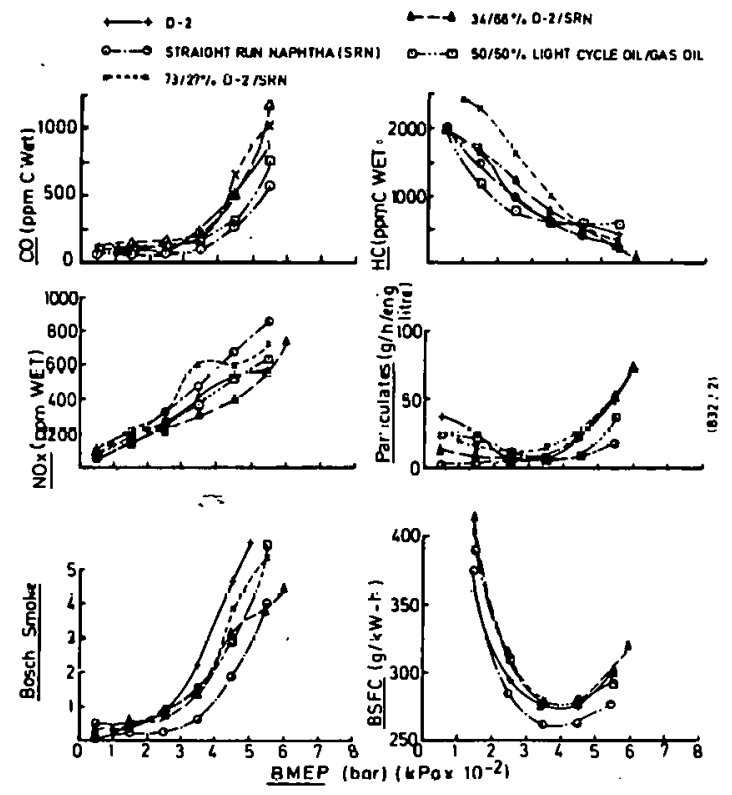

FIGURE 23 - PERFORMANCE AND EMISSIONS AT $25 \mathrm{rev} / \mathrm{s}(1500 \mathrm{rev} / \mathrm{min})$ - TEXACO TCCS COMBUSTION SYSTFM

speeds, it was judged that the time and cost penalties which would be incurred by refurnishing the oll pump would be unjustiflable and further testing was, therefore, aborted.

Fuel Consumption - At $40 \mathrm{rev} / \mathrm{s}$ (2400 rev/min) (Fig. 24) this combustion system exhibits good fuel tolerance, the worst fuels generally showing consumption no more than about $5 \%$ higher than the best fuels. At the very highest loads, however, thls does increase to nearer $10 \%$ with the two most volatile fuels showing best economy. At mid to light loads the narrow bandwidth makes interpretation difficult but it is apparent that the D2 is tending to exhlblt best economy. There results possibly imply that at lighter loads the less volatile D2 encourages effective stratification whilst its high ignition quality improves combustion via autolgnition of isolated fuel pockets following inltiation of combustion by the spark. At the higher loads it is presumed that the preference for the more volatile fuels is due to the more effective mixing of fuel and alr.

At the lower test speed (F1g. 23) the system exhibits less tolerance to the range of fuels tested, the bandwidth here being typlcally $10 \%$ at all loads. Again, for best economy the system shows a preference for D2 at light load, and the more volatile naphtha at high loads. However, the advantage of the naphtha is maintained in this case at mid-loads, probably. reflecting the benefits of the improved mixing of the fuel and air under the conditions of reduced cylinder temperatures and swirl at this speed.

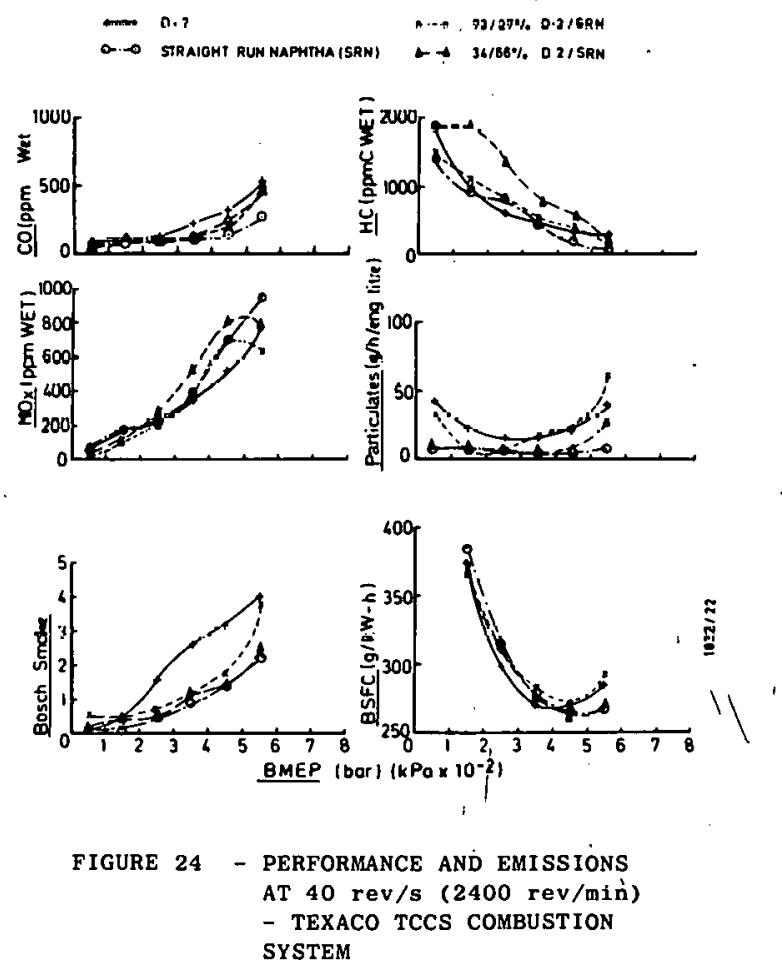


NOx Emisstons - The NOx emisstons patterns at both test speeds are typlcal of an open chamber combustion system and do not exhibit the part load peak usually assoclated with swirl chamber englnes. There are no clear indications of NOx enissions belng modified solely as a result of fuel specification, the distribution of Individual curves being largely dictated by the timing requtrements for minimising fuel consumption. (See Appendix $5 \mathrm{e}$ ).

HC Emissions - The general response for all fuels at both speeds shows an almost linear rise for HC froin relatively low levels at full load, to very hIgh levels at light load, this being a typical characteristic of open chamber stratifled charge combustion systems (7). The trend is usually attributed to fuel belng swept away from the fringe of the spray at the lower fuelling level, light load conditions, resulting in pockets of inixture too lean for successful combustion. Across both speeds examined, there are no readily identifiable trends which can be related to differences in fuel spectification alone.

Exhaust Smoke - The exhaust smoke results clearly indicate fuel sensitivity, with the volatile fuels showing the ability for lower smoke formation, and D2 showing the h1ghest levels. This effect has been observed with other combustion systems and is attributed to the higher volatility improving the degree of mixing between fuel and atr.

Throughout the TCCS test work, the spark timing (as approved by White) was maintained at $3-5^{\circ}$ crank before the start of injection in order to ensure that the multistrike ignition source was established by the start of infection. This minimizes HC emissions and avolds detonation. However, th is known that with high octane fuels it is possible towards full load to retard the ignition to a point after infection of the fuel, without inducing detonation (1). This allows a proportion of the fuel to become premixed enabling a reduction in smoke and a corresponding improvement in smoke limited torque. The highest octane fuel used during this programme was the naphtha ( 70 RON) and the above mentioned procedure was attempted with this fuel. A retard of the spark relative to the start of injection of only $3^{\circ}$ crank angle was achleved, howerer; bcforc the onoot of hoavy detonation. With this degree of premix, no reduction in smoke was observed.

Particulate Emissions - With each fuel producing broadly equivalent and relatively low HC emissions towards full load, the particulate trends here are primarily controlled by exhaust smoke. Thus the more volatile fuels tend to exhibit the lowest particulate enission. At light loads where smoke levels ate luw and HC eülssions simflar and high, tt would be expected for particulate formation to be controlled by the HC 1 evels and $11 \mathrm{kew} 1 \mathrm{se}$ be broadly similar at high levels. Huwever, thils is aut the case, the less volatile fuels showing expected high levels of particulate whlle the more volatile fuels show significantly reduced output. It is again thought that the nature of the HC species emitted must be responsible, the combustion conditions with the more volatile fuels approaching those more typical of a gasoline engine and as such producing
IiC species not conducive to particulate formation.

CO Emissions - At the lower test speed, (Fig. 23) the co results respond in sympathy with smoke output. At the higher test speed, trends are not so well defined, although there is evidence that the coinbination of higher volatility and relatively high ignition quality with the predominantly diesel broadcut fuel pronote lmproved fuel preparation and combustion resulting in the lowest $\mathrm{CO}$. Why the other fuels show greatly increased $C O$ output not reflected in results with the other varlables is not fully understood, but it should again be sald that the levels in question are all very low as is usual for unthrottled operation, and not considered problenatical.

Smoke Limited BMEP - As would be expected, the highest BMEP levels (F1g. 25) were recorded with the more volatile fuels where smoke formation is attenuated. Unl1ke the SIIDI combustion system no operability problems were encountered at high speed and each fuel can successfully over the load range at the manufacturer's rated speed $(58.3 \mathrm{rev} / \mathrm{s}$, $3500 \mathrm{rev} / \mathrm{min}$ ). With the TCCS system, the colncidental ignition and injection thing avoids premixing and autolgnition with its associated loss of spark management of the combustion process.

Igntting the 'wet' fuel spray does however require a very high energy, multistrike ignition source as produced by the Echlin unit employed during these tests.

$+0+0.2$

O- STRAIGHT RUN NAPHINAISRM I

23/27\% 0.2/SRN

D $50 / 50 \%$ LIGHI CTCLE OIL /GAS OL

* 40 Bosch Smoke Limits.

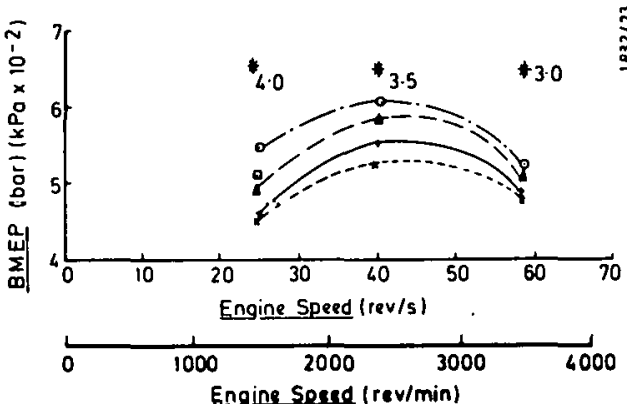

Engine Soerd (rev/min)

FIGURE 25 - SMOKE LIMITED BMEP CURVES TEKACO TOOE COMBUETION SYSTEM 
SPARK IGNITED DIRECT INJECTION (MAN FM) COMBUSTION SYSTEM - (FIGURES $26,27,28$ )

Fuel Consumption - Fuel consumption at the lower test speed, (F1g. 26), demonstrates a marked response. At high load, lowest fuel consumption was achieved with the most volatile naphtha fuel. Heavier fuels tended to increase consumption progressively with high ignition quality D2 returning the worst consumption levels. Similar trends were apparent at high load, $40 \mathrm{rev} / \mathrm{s}(2400$ $\mathrm{rev} / \mathrm{m} / \mathrm{n}$ ) (F1g. 27). At the l1ghter loads more representative of 11ght duty applications, fuel effects were still evident at the lower test speed. Here, economy levels were sintlar for both broadcut fuels whllst stralght run naphtha and the two dlesel fuels returned 7-11\% worse fuel consumption. S1milar trends were apparent at the 11 ghter load factors, 40 $\mathrm{rev} / \mathrm{s}(2400 \mathrm{rev} / \mathrm{m} 1 \mathrm{n})$ although in this instance, the overall fuel sensiclvity was reduced.

The preference for broadcut fuels for maximum 1 ight load economy 18 probably a result of their enhanced volatility whilst st111 retalning a relatively high 1gnition qualley. These characteristics would encourage effective mixing of the fuel and air and assist the spark inftlated combustion by some degree of autolgnition of remote fuel pockets.

At the higher load factors where all of the fuel is nominally sprayed onto the combustion chamber wall, the more volatile fuels undoubtedly encourage effective preparation of fuel and a1r resulting in economy gains. This would also account for the greatest fuel sensitivity being at low speed where

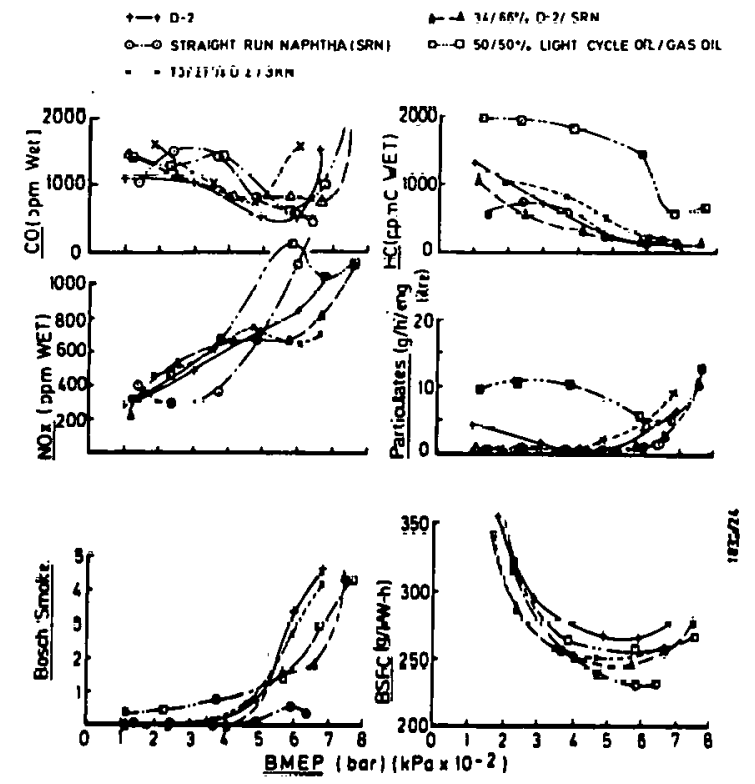

FIGURE 26 - PERTORMANCE AND EMISSIONS AT $28 \mathrm{rev} / \mathrm{s}(1800 \mathrm{rev} / \mathrm{m} / \mathrm{n})$ MAN FM COMBUSTION BYBTEM the energy of the swirling air is reduced and the benefits of Increased volatility become more i.mportant.

With high ignition quality fuels, where the autoignition quallty of the fuel is able to ignite the charge in lieu of the sparking plug, the FM combustion system exanined in this programme tended to operate as a low coinpression ratio diesel. With D? ( $48 \mathrm{CN}$ ) at both test speeds this effect occurred at load factors in excess of about 2.5 bar BMEP. With the fuels of approximately $35 \mathrm{CN}$ the onset of this behaviour was above about 5 bar BMEP. It is thought that this autolgnition may have deleterlous effects on fuel consumption contributing to some of the trends observed, although the mechanism is not fully understood. When operating thus, combustion did not demonstrate the instability problers exhlbited by the SIIDI system under similar clrcumstances, and 1t was not necessary to curtall rescing tintil some other limiting criterion was reached, usually the onset of detonation.

The tendency observed on this programme to sutoigntte demonstrates a signiflcant difference between the MAN FM and the Texaco TCCS system. In the case of the TCCS, the high energy, multistrike 1gnition source timed colncldent with the start of fuel injection ignites the 'wet' fuel spray. Incidences of 'dleseling' elther go unnoticed, or more probably, because of the colncident ignition and injection timings and the high energy of the ignition source, do not occur. W1th the FM system evaluated, the opt Imum spark timing was within the latter half of the infection perlod (see Appendices
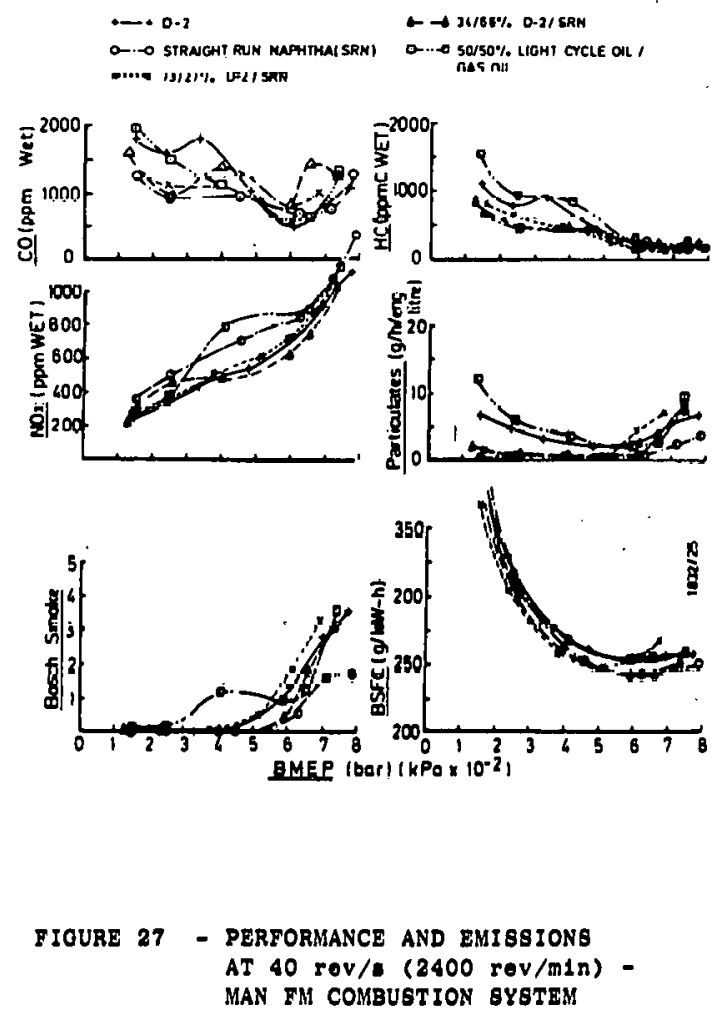
$5 f$ and $5 g$ ) and the spark is therefore lgniting prepared fuel. This spark timing required determination by experimentation and during this it was noted that the start of pressure rise was not always controlled by the spark with high ignition quality fuels. Because the FM system relles on a degree of prepared charge to Ignite after injection, with a relatively low energy spark, the premdx introduced enabled the system tested to emit less smoke than the TCCS. Premixing d1d, however, tend to introduce instances of detonation limited load, a situation exacerbated by the low octane fuels addressed during this programme. In the case of the TCCS system, the lack of premixing causes the maximum fuelling level to be limited by exhaust smoke and detonation only occurred if the infection and 1gnition timing were excessively advanced, or premixing introduced by retarding the spark relative to the infection. The maximum allowable degree of premix between the two systems is blased in favour of the FM. For stra1ght run naphtha ( 70 RON) it has previously been stated that only $3^{\circ}$ crank of premix could be introduced with the TCCS before excessive detonation occurred. W1th the FM system evaluated on this fuel, about $30^{\circ}$ crank angle of premlx can be utilized at high load factors to achleve optimum economy without Incurring excessive levels of detonation. Detonation does, however, Invariably linit the load range if peak fuelling levels are further increased. In this case, it cannot be overcome by advancing the spark significantly into the infection period as the relatively low energy ignition source breaks down, presumably due to plug wetting. The fundamental differences between the allowable degree of premlx between the FM and TCCS systems must be related to the effective stratification evolved by spraying the fuel nominally onto the combustion bowl wall as opposed to the alrbourne injection of the TCCS.

NOx Emlssions - As with the TCCS, the NOx em1ssions are typical of an open chamber combustion system. Although falrly large variations are evident between fuels, particularly at the lower test speed, they cannot be readily related to fuel type or always interpreted against the respective starts of pressure rise. The magnitude of the relationships no doubt represents a complex interaction of many variables.

HC Em1ssions - The HC results are again as expected for an open chamber direct injection stratified charge engine, 1.e. rising from relatively low levels at high load factors to high levels at 11 ght load. At high load factors, HC emissions are generally comparable between fuels. As the load 1s reduced HC emissions become sensitive to fuel volatility with the heavier fuels demonstrating the highest levels. This trend is particularly marked at low speed with the aromatic alternative diesel fuel (F1g, 26). In this case the response 1s presumably. enhanced by the lower swirl levels prevalent within the combustion bowl.

Exhaust Smoke - The use of a degree of premlxing with this combustion system results in generally low smoke levels up to about 5 bar BMEP with all fuels. However, with the heavler fuels in particular, a sharp rise in smoke at the higher load factors occurs. For lowest smoke, the system clearly favours the volatile fuels presumably due to their ability to assist in fuel and air mixing processes and improve the efficiency of combustion.

Particulate Emissions - The particulate emlssions response of the FM system is simllar to that previously discussed for the TCCS. At high fuelling levels with comparable HC emlssions, particulates are controlled by smoke and are, therefore, lowest with the most volatile fuel. At $11 \mathrm{ght}$ load, particularly at $40 \mathrm{rev} / \mathrm{s}(2400 \mathrm{rev} / \mathrm{m} 1 \mathrm{n})$ (F1g. 27) the data again suggests that the HC spectes produced by the more volatile naphtha and broadcut fuels are not conducive to particulate formation, enabling these fuels to return lower particulates despite high gaseous HC levels. The very high response at $25 \mathrm{rev} / \mathrm{s}$ ( $1500 \mathrm{rev} / \mathrm{m} / \mathrm{n})($ P1g. 26) w1th the low ignition quality, highly aromatic diesel fuel is clearly related to the high HC and part load smoke trends apparent with this fuel.

CO Emissions - At both test speeds, Co emissions in the FM systell are lowest, irrespective of fuel, at approximately three-quarters full load. Reducing load below this increases co emissions linearly to a maximum at light load. Th1s trend is not fully understood given the low part load smoke characteristics but 18 clearly defined across the range of fuels.

Although this trend results in overall co emissions being higher than those for the other systems evaluated, levels are again low as characterised by unthrottled operation.

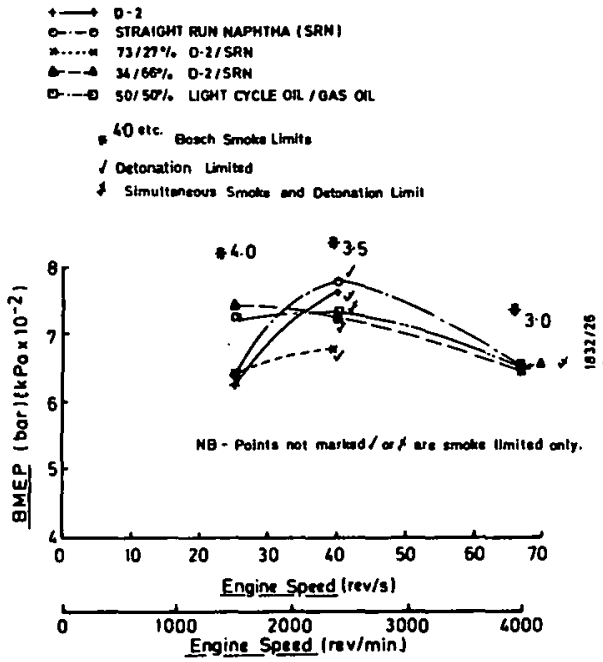

FIGURE 28 - SMOKE OR DETONATION LIMITED BMEP CURVES - MAN FM COMBUSTION SYSTEM 
Smoke Limited BMEP - The curves show that with the combustion system exainined, the maximum BMEP obtainable was frequently limited by the onset of detonation (F1g. 28). With the highest ignition quality fuels, detonation occurred at very low loads when operating at higher speeds thus limiting the practical rated speed to below about $50 \mathrm{rev} / \mathrm{s}(3000$ $\mathrm{rev} / \mathrm{m}(\mathrm{n})$. With the lower ignition quality fuels an acceptable maximum load could be achieved at a realistic rated speed for light duty operation, full load at this speed being the same for the naphtha, predominantly naphtha broadcut, and highly aromatic diesel fuel. The highest peak torque was achieved with the naphtha, this point being detonation IImited, demonstrating that for higher torque, (7) high octane fuels to resist detonation are required. At low speed, however, maximum BMEP with naphtha was Ilmlied by luss of successtul ignition due to sparking plug wetting.

\section{OPERATIONAL CONSİ́DERATIONS}

STARTABILITY - Throughout this programme, evaluations were made of the ability of each combustion system to start and idle on each fuel. For these tests the englnes were decoupled from thetr dynamometers, and, in the case of the single cylinder englne, cranking speed and idle speeds set to $6 \mathrm{rev} / \mathrm{s}$ and $11 \mathrm{rev} / \mathrm{s}(360 \mathrm{rev} / \mathrm{min}$ and 660 rev/min) respectively. Note that this cranking speed is typically twlce that of a multicylinder Installation. This represents a limitation loposed by using a single cylinder engine where high starting motor torque is required to overcome compression without the assistance of a complementary expanding cylinder. For the multicylinder DI diesel and TCCS engines, cranking and litle speeds were left at their developed settings.

Tests were not conducted below laboratory amblent temperatures of typlcaly $15^{\circ} \mathrm{C}$ since such work would have been outslde the scope of the contract. Results for each system were as follows:-

IDI Diesel Combustion System - This combustion systell $1 \mathrm{~b}$ generally tecognised as being problematical with respect to cold starting, requiring the use of high. compression ratios and starting alds, the most cormon of these being the electrically heated glow plug. As a result of this, the starting evaluation tests with this sytem were more complicated than with the other systems, since it was possible to make observations both with and without the heater plug, those without belng able to Indicate the effects of different fuel opcciflcations more cleariy.

Figure 29 shows that in order to start after 1 s of cranking (this was the shortest interval which could be recorded and really represents instantaneous starting) without the heater plug, the lowest ignition quality aromatic diesel fuel proved to be the worst fuel requiring the water jacket temperature to be above $65^{\circ} \mathrm{C}$. The $\mathrm{D} 2$ demonstrated the best starting ability giving a start within is at a water facket temperature of $30^{\circ} \mathrm{C}$. Between thase two extromes it can be sten that d relationship exists that can be attributed to effects of ignition quality and volatility. The broadcut fuels and the naphtha require progressively

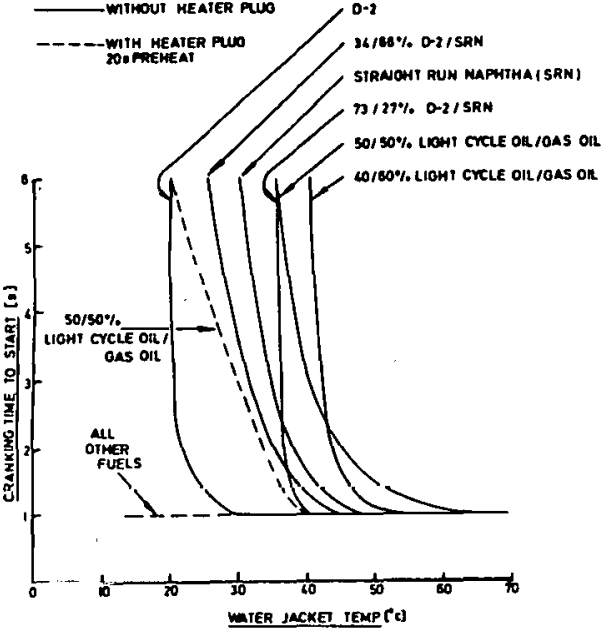

FIGURE 29 - STARTABILITY EVALUATION IDI DIESEL

higher water jacket temperatures as Ignition qualiry reduces, in order to start within ls. However, the rwn highly aromatio diesel fucls laviug lgulilui qualities comparable to the two broadcut fuels require higher temperatures to start than even the naphtha indicating that the higher volatility of the naphtha and broadcut blends helps tn nffeer thots roduced Ignition quality (1).

At lower temperatures where the fuels required longer cranking times in order to achleve a start, the same relationship between fuels generally exists. The two cases where fuels have altered their relative position can be attributed partly to mechanisms not fully understond, and partly to the difficulty in accurately timing the period of cranking to a successful start.

When pvalithling the ahllity to otart with.thc ald of a heater plug, only one fuel falled to otart within ls at the minimum laboratory temperature. This fuel, the low ignition quality aromatic diesel fuel, required a minimum water jacket temperature of $40^{\circ} \mathrm{C}$ for starting to be instantaneous, while ar $20^{\circ} \mathrm{C}$ a successful start had not been achleved even after $6 \mathrm{~s}$ cranking. It must be recognised that the excellent starting characteristics recorded here with the other low Ignition quality fuels (using heater plug) are not likely to be exhlbited at lower temperatures more typical of winter operation. At lower remperatures an lgnition quality/starting characteristic trade-off would be anticipated in a similar fashion to those tests performed without the heater plug. 
During all the tests described above, once a start was achieved it was followed by successfully sustained Idle operation without the heater plug being energised.

DI Dlesel Combustion System - As has been previously discussed, (see Section 12) this combustion systern was evaluated with three fuels only; $D 2$, the predominantly diesel broadcut and the low ignition quality, highly aromatic diesel fuel. The first two fuels started within 1 s cranking and idled smoothly without excessive smoke at an amblent temperature of about $15^{\circ} \mathrm{C}$. The third fuel again started instantaneously, although this was followed by a short perlod of very rough 1dling accompanied by dense white smoke before a stable idle was malntained.

SIIDI Combustion System - Owing to the mechanical problems encountered with this engine and the time-scale limitations so imposed, no starting evaluations were made. Previous RIcardo experience (1) with an engine of this type using gasoline and diesel fuels would suggest that at laboratory ambient temperatures, starting would have been successful on the fuels encompassed by this programme.

Texaco TCCS Combustion System - At an ambient temperature of about $15^{\circ} \mathrm{C}$, this engine started instantly and idled without problems on all five fuels evaluated. No particular sensitivity to injection or spark timing requirements was observed.

MAN FM Combustion System - Th1s combustion system started within a is cranking period at an ambient temperature of about $15^{\circ} \mathrm{C}$ with all five fuels evaluated. However, two observations can be made. Firstly, after starting with the low ignition quality highly aromatic diesel fuel, the englne was seen to have a rough 1dle, this belng attributed to the low volatility of the fuel inhibiting ef fective preparation with alr, hence making ignition of the mixture more problematical. Its low ignition quallty represents a further factor resisting effictent continuation of combustion. That this fuel did not cause problems with the superficially similar TCCS system can be attributed to the high energy, long duration multistrike ignition system used on this eng1ne, which has little difficulty in igniting and maintaining combustion under these cundliluns. Tlie secund piolilea observed was with the naphtha fuel. In this case, the spark timing employed for instant starting resulted in a rough 1dle. Retarding the spark by about $2^{\circ}$ crank resulted in smooth idle operation but made cold starting more difficult. The reasons for these effects are not fully understood, but it is considered that specifically directed effort, outside the scope. of this contract, would overcome the problem. As such it 18 not thought that it need reflect on the ability for the combustion system to start on this fuel.

LIMIIAlIONS - Ih1s section is cuncermed wh areas of operation prohibited to each combustion system, primarlly resulting from the onset of misfire or detonation. It should be remembered here, particularly in the context of misfire and the diesel engine, that within th1s programme degrees of retard compatible with low Nox levels suitable for meeting light duty standards were not addressed.

IDI Diesel Combustion System - At the two main test speeds of 25 and $40 \mathrm{rev} / \mathrm{s}(1500$ and $2400 \mathrm{rev} / \mathrm{min})$ two problem areas were observed. At the lower test speed, the low Ignition quality alternative diesel fuel entered into a reglme of misfire at $11 \mathrm{ght}$ load and was limited within this programme to a minimum of about 1.5 bar BMEP. To achleve th1s, advanced timings were required. Further testing with even greater degrees of advance to extend the load range and possibly reduce the high levels of $\mathrm{HC}$ emissions was not carried out owing to timescale 11mitations. The problem is undoubtedly due primarily to the low ignition quality of the fuel, this belng made worse by the low volatility which obviously benefits the naphtha and broadcut fuels under these difficult conditons of reduced swirl and combustion chamber temperature. In the context of the very low ignition quality naphtha, misfire was also encountered at the $11 \mathrm{ght}$ load factors with the most retarded timing investigated. The significance of these light load misfire problems when retarding for low NOx is reviewed later in this report.

At the rated speed of $70 \mathrm{rev} / \mathrm{s}(4200 \mathrm{rev} / \mathrm{m} / \mathrm{n})$ a trend was apparent across the range of fuels at light load. Figure 30 demonstrates that when operating on D2, a large 'window' of injeotion tiolng is avallable over which misfire free operation is possible. Passing through the broadcut fuels to naphtha shows the necessity to progressively advance injection timing in order to avold misfire: In the case of the naphtha only a small timing 'window' is avallable, any further advance causing the combustion system to enter a regime of subjectively unacceptable nolse.

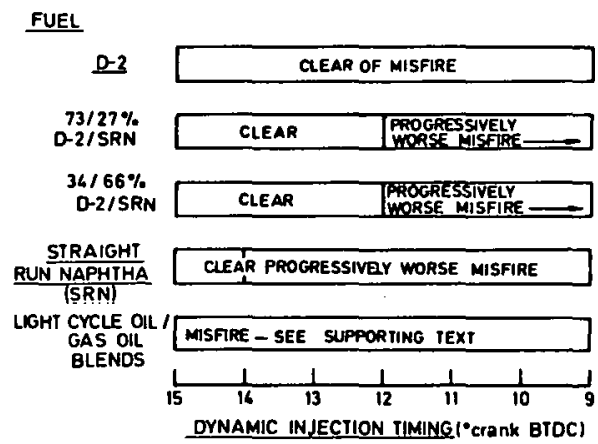

\footnotetext{
FIGURE 30 - COMPARISON OF MISFIRE REGIMES - IDI DIESEL

- $70 \mathrm{rev} / \mathrm{s}(4200 \mathrm{rev} / \mathrm{min})$, 1 har RMFP (100 kPa)
} 
Evaluation of the low ignition quality alternative diesel fuels falled to identify an injection timing with which operation at this load and speed was posstble. The operation of the engine was suspect and check tests were made w1th D2 fuel. In th1s case, running at light load rated speed also resulted in combustion instabllity with occasional misfire, although performance at 25 and $40 \mathrm{rev} / \mathrm{s}$ ( 1500 and $2400 \mathrm{rev} / \mathrm{min}$ ) was unaffected. It was belleved that an injection system malfunction had developed but this could not be rectified within time limitations (note - this phase of the work was carried out last in the IDI programme). The aforementioned observations with the alternative diesel fuels are, therefore inconclusive.

DI Diesel Combustion System - The problem concerning vapourization in the tuel pump of the volatile naphtha fuel fractions has already been described. However, although this effect must be avolded in order to operate with this type of fuel and injection équipment combination it is not directly a shortcoming of the combustion system 1tself. For those fuels which were evaluated, no limitations to cheir scope of operation were observed.

SIIDI Combustion System - Three main problem areas were observed. The first problem was that operation with naphtha at the two main test speeds (25 and 40 $\mathrm{rev} / \mathrm{s}$ ) was precluded by rapid sooting of the sparking plug, followed by loss of ignition as the spark tracked to ground across the insulator in preference to fumping the gap. Previous experience (4) with a comparable combustion system had shown satisfactory operation with 91 octane gasoline, and the fallure of the present system to operate on naphtha was surprising and would certainly be avoldable with further development, specifically in respect of the heat range of the sparking plugs ut1lised.

The second problem concerned difficulty experienced with light load operation at $25 \mathrm{rev} / \mathrm{s}$ (1500 rev/min) for all fuels and at $40 \mathrm{rev} / \mathrm{s}$ ( $2400 \mathrm{rev} / \mathrm{min})$ with the predominantly naphtha broadcut blend. In these areas, the onset of misfire prevented operation below about 2 bar BMEP under the usual conditions of progressively reducing load during evaluation of the load range. If, however, a minimum load point was set Immediately after a high load point, the higher prevalling temperatures successfully prevented misfire until the combustion chamber again cooled. This Indicates that the problem (again not previously observed with a comparable combustion system) was marginal and could certainly be eliminated with specifically directed development, and in the context of this work should not be considered an inherent falling of the combustion system.

The third problem concerned the fallure of the system to operate at a realistic rated speed with D2. W1th th1s fuel, the high 1gnition quality promoted autolgnition with higher fuelling levels at speeds in excess of about $50 \mathrm{rev} / \mathrm{s}(3000 \mathrm{rev} / \mathrm{m} 1 \mathrm{n})$ resulting in loss of spark control and unstable, erratic combustion. Th1s behaviour is indicative of the general preference of the particular combustion system evaluated for low ignition quality fuels. It has been stated previously in this report (see Section 6) that the system procured for this programme represented a compromise for the range of fuels to be evaluated, based upon past Ricardo experience with a similar system (4). Within this past experience, high load factor operation at high rated speeds has been achieved with high 1gnition quality diesel fuels. It is likely therefore, that the problems related here could be overcome by detalled development for particular single fuel operation. One of the prime variables to be considered would be compression ratio.

TCCS Combustion System - Th1s combustion system proved to be remarkably tolerant to variation in fuel specification in that there were no instances of areas of operation belng prohiblted as a result of such effects as misfire or detonation. Th1s reflects the substantial multifuel develonment. accorded to the L-163-S engine in the past and the use of the high energy, multistrike ignition source which is timed to be coincident with the injection of fuel. The lack of premlxing and high energy of the ignition source pre-empts instances of autoIgnition and any tendency to detonate, whilst also successfully inhiblting misfire at light loads.

FM Combustion System - With the FM combustion system examined here, operational limitations were observed primarily with high ignition quality fuels. The problems were closely assoclated with the abllity of such fuels to autolgnite, and directly affected the englne speed range avallable.
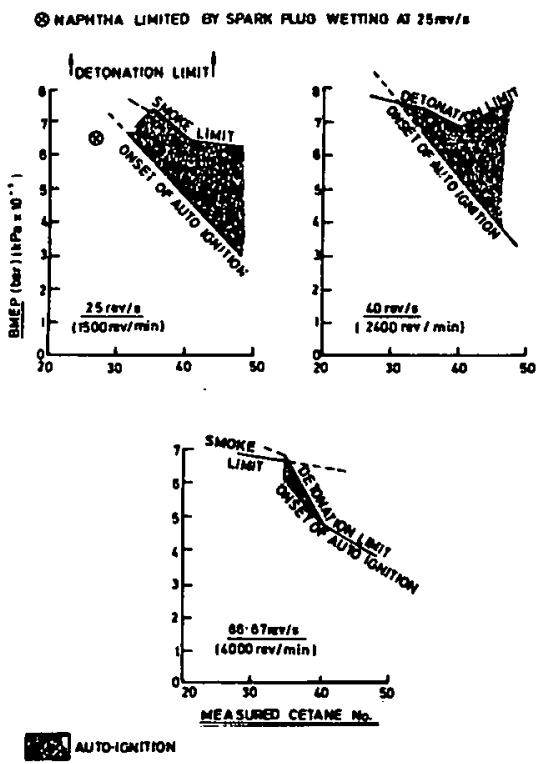

FIGURE 31 - MAN FM-REGIMES OF
AUTOIGNITION AND DETONATION LIMITS 
The effects are demonstrated in Figure 31. At the lower test speeds of $25 \mathrm{rev} / \mathrm{s}$ ( $1500 \mathrm{rev} / \mathrm{min}$ ) it can be seen that the combustion enters an autolgnition mode at progressively lower loads as ignition quality $1 \mathrm{~s}$ improved. This behaviour is caused by the high ignition quality of the fuel initlating combustion instead of the spark.

It is not fully appreciated why the spark should become Ineffective as. an ignition source. It may be that sparking plug wetting occurs although this can usually be observed when monltorling the spark energy discharge characterist1cs on the oscilloscope. If this occurs, it is no doubt exacerbated with the higher Ignition quality fuels olnce these are less volatile. At this low speed, however, where cylinder temperatures and swirl levels are low coupled with. lower quantities of fuel injected during the Ignition lag, conditions result where the quantity and quallty of premixed fuel enables the system to continue operation as a diesel to higher load factors, beling eventually limited by levels of smoke.

At the higher test speed of $40 \mathrm{rev} / \mathrm{s}(2400 \mathrm{rev} / \mathrm{min})$ it can be seen that the same relationship exists between the onset of autolgnition and the 1gnition quality of the fuel. Again the combustion can continue to operate as a diesel to higher load factors. At thls speed, however, greater quentity and quality of premixed fuel occurs, resulting in earlier onset of detonation, this in fact limiting maximum BMEP prior to, or colncident with, the smoke $\lim t$.

At the highest opeed evaluated, $66.67 \mathrm{rev} / \mathrm{s}(4000$ $\mathrm{rev} / \mathrm{m}(\mathrm{n})$ the relationship between onset of autoignition and ignition quality 18 again as seen at the other test speeds. During the autolgnition mode at this speed, however, the resultant degree of premixing is excessive which manifests as much earlier onset of detonation. W1th the D2 (48 CN) and the predominantly D2 broadcut fuel $(40 \mathrm{CN})$, occurrence of detonation was colncident with the start of autolgnition, precluding any operation in the diesel mode and gerlously liniting the avallable torque. With the other broadcut fuel and the highly aromatic diesel fuel a perlod of operation in the diesel mode was possible, enabling higher loads to be reached.

At all speeds, the very low Ignition quality naphtha was the only fuel tested which did not show a tendency to autolgnite, and as such spark control was maintained at all time. The onset of detonation again limlted the peak fuelling however.

Operation during detonation modes is precluded by rapid sparking plug fallures owing to the violent pressure fluctuations prevalent.

The result of the above is that with this combustion system, the high ignition quality fuels demonstrated a seriously truncated load range at high speed, or conversely, a serlously limited speed range if realistic torque levels are to be achieved.

It should be remember however, that the combustion system as tested was designed as a compromise judged at the outset of the programme. The selection of a compression ratio of $12.5: 1$ was primarily based on experience of the system and its octane sensitivity with gasoline type fuels. As such, the chosen compression ratio was blased towards successful operation with naphtha and low ignition quality broadcut fuels, rather than high ignition quality diesel fuels which are naturally well sulted to the diesel englne.

It is known, however, that the Fir system can be made to operate successfully with a wide speed range on high ignition quality diesel fuels. This is achieved by increasing the compression ratio to approximately $16: 1$ and running the system as an $M$ system diesel. The sparking plug is then used for starting, or assistance at $11 \mathrm{ght}$ load. Indeed, this is the phllosophy behind military multifuel applications of the FM syster. In this case, the sparking plug is used exclusively for operation with high octane gasolines and generally switched off for h1gh 1gnition quality diesel fuel operation. Again, th1s philosophy would not have sulted this programe because of the low octane quality of stralght run naphtha.

Naturally the FM principal can be uniquely tallored via development for successful single fuel operation. As such 1t should perform better overall than the results indicated here, or Indeed, by the past military multifuel engine experience.

IGNITION DELAY IN DIESEL COMBUSTION SYSTEMS - The current technique for rating the Ignition qual1.ty of diesel fuels relles on abcertaining the ignition delay period which arises with each fuel in a test engine (usually the CFR englne). The CFR engine employs a combustion system which 16 not representative of automotive diesels. Concern is now belng shown within the industry over the lack of correlation sometimes obgerved between the cetane rating determined in the CFR rating engine, and the measured Ignition delay in automotive diesels. Such differences appear to be more pronounced with fuels outside the range of commonly used petroleum based fuels (1.e. coal or vegetable based fuels, etc.,).

Consideration of the delay periods imposed on the diesel combustion systems by the various fuels used in this programme 18 an 1mportant part of the overall understanding of effects observed when using these fuels. Figure 32 therefore, shows the actual ignition delay perlods determined with the diesel systems during the multicylinder screening tests and the fundamental study, plotted against cetane number as rated by the CFR engine. Various observations can be made.

In the case of the IDI diesel, it can be seen that the Ignition delay response to varying cetane number is generally as would be expected 1.e. both the Task 2 multicylinder engine and the Task 3 oingle cylinder engine demonstrate Increasing delay periods as cetane number is reduced. W1th the DI system, however, a different picture emerges. The rask 2 fuels (using additives to vary cetane rating) behave as expected and demonstrate an increase in ignition delay with lower cetane number. This trend was not evident with the Task 3 fuels (petroleum derived dlesel and broadcut fuels). W1th these fuels the 48 CN D2 demonstrates good repeatability w1th Task 2 


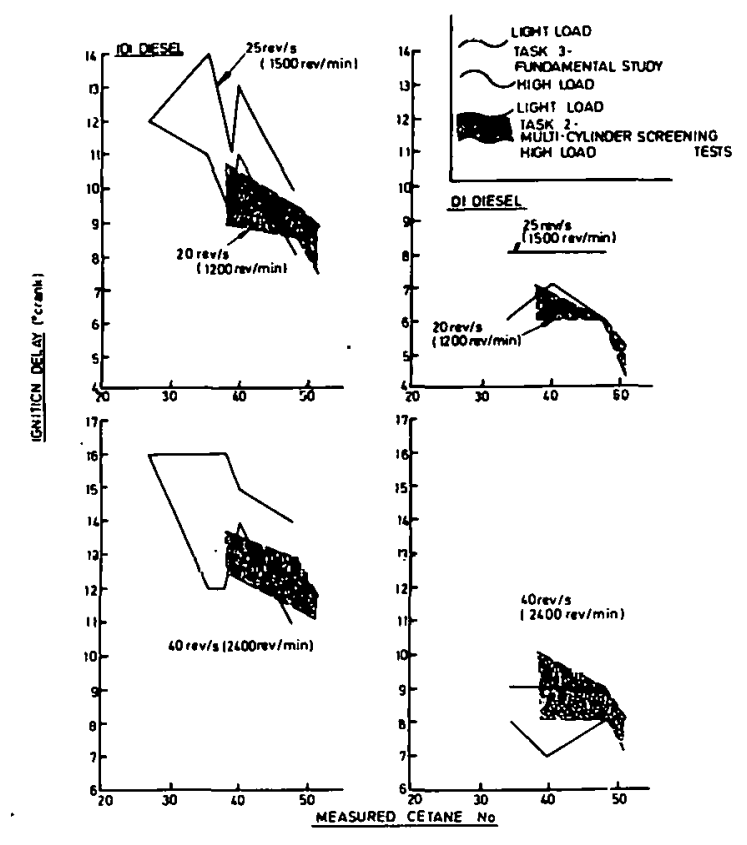

$\begin{array}{cc}\text { FIGURE } 32 & \text { - IDI \& DI DIESELS COMPARISONS } \\ & \text { OF OBSERVED IGNITION DELAY } \\ & \text { WITH RESPECT TO MEASURED } \\ & \text { CETANE NUMBER }\end{array}$

data (allowing for the differences in speed at the lower speed) while the other two fuels ( 40 and 34.5 $\mathrm{CN})$ show no ignition delay response to their different cetane ratings. This tendency for the observed ignition delay with these fuels not to reduce with decreasing CFR determined cetane rating may well help to explain some effects discussed earller and refterated below.

The single cylinder IDI combustion system demonstrated during the starting tests that for instant starting to be achieved, higher water jacket temperatures were required as the measured cetane number was reduced (although as has been discussed the effect of volatility is superimposed on this trend). Th1s reflects the greater reluctance of these low cetane fuels to ignite in this combustion system as also demonstrated by the longer ignition delays. Conversely, the DI diesel started instantly at low ambient temperatures on fuels from $48 \mathrm{CN}$ to $34.5 \mathrm{CN}$, without assistance from heater plugs, this being compatible with the observed ignition delay informatinn.

Furthermore, the IDI diesel system suffered from the onset of light load misfire below about 3.5 bar BMEP, at $25 \mathrm{rev} / \mathrm{s}(1500 \mathrm{rev} / \mathrm{min})$ with the highly aromatic low ignition quality diesel fuel requiring the adoption of an advanced injection timing to curtall the problen. With the DI system, however, the lack of any 1ncrease in ignition delay with this fuel enabled misfire free running at $11 \mathrm{ght}$ load even when operating at relatively retarded injection timings.
In addition the unresponstueness of the DI system in respect of ignition delay no doubt helps account for the overall high degree of fuel tolerance recorded during the fundamental study.

These observations well lllustrate the limitations of the CFR cetane rating technique not only between types of combustion system, but also between different fuel groups within a system. Th1s assists in highlighting the need for $\dot{z}$ new fuel rating technique and provides appreclation of the need to treat interpretation of curent ratings with care.

MECHANICAL CONSIDERATIONS - Throughout th1s programme, cylinder pressure levels were recorded with a Kistler 6121 callbrated pressure transducer and photographlc records were made of the pressure diagrams as displayed on the oscilloscope. This

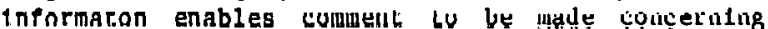
pressure levels, with their attendant design implications, and allows a degree of confirmation that subjective nolse assessment during the progriammé gêterally correiared wich curabustluu conditions.

For the spark 1gnited combustion systems, maximum firing pressures at full load were relatively low as expected (Figure 33), being generally in the range 45-60 bar, and were not greatly influenced by changes in fuel specification, the spread across the range of fuels at each speed belng about 5-10 bar. These low firing pressures are more typical of a gasoline engine and as such they allow gasoline engine conversion policles to be adopted with

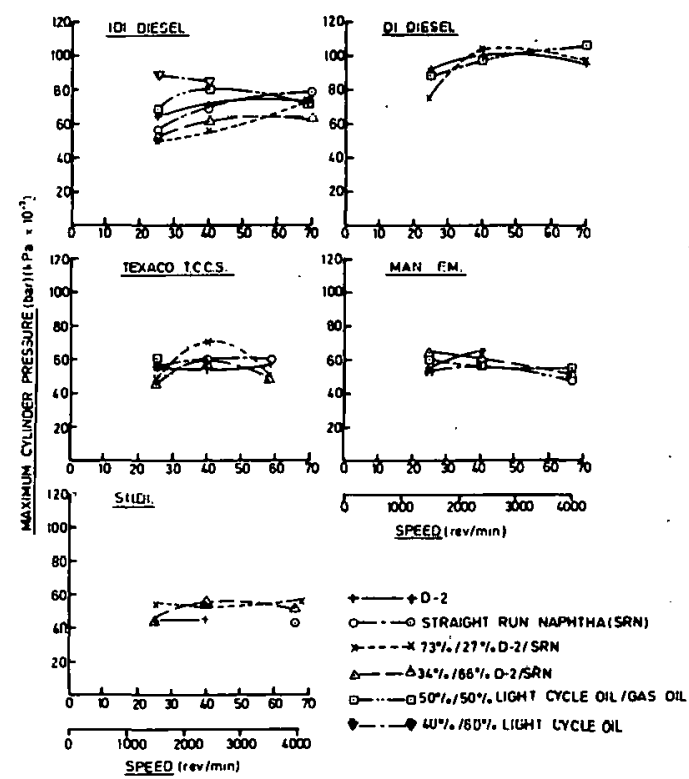

FIGURE 33 - COMPARISON OF MAXIMUM, CYLINDER PRESSURE AT FULL LOAD 
attendant design and cost savings. Low firing pressures also result in reduced levels of engine friction and hence allow potential improvements in brake specific fuel consumption relative to the high friction diesel engine.

The degree of advantage over the diesel combustion system becomes apparent when it is considered that the IDI diesel demonstrated peak pressures of up to about 80 bar, a typlcal figure for this type of system with optimum performance infection timing. When operating on D2, peak pressures rising from about 60 bar at full load, low speed to just under 80 bar at rated speed were observed. Operation with naphtha demonstrates roughly comparable cylinder pressures, whilst the broadcut blends showed slight reductions in peak pressures. At 25 and $40 \mathrm{rev} / \mathrm{s}$, ( 1500 and $2400 \mathrm{rev} / \mathrm{min}$ ) the two highly aromatic low ignition quality diesel fuels demonstrated increases in peak cylinder pressures relative to D2, the worst case observed being with the higher ignition quality alternative fuel at the lower speed, where pressures of about 85 bar were recorded. Interpretation of the different peak pressures resulting from the various fuels evaluated with the IDI system is not simple, these being a complex interaction of many variables such as infection timing, ignition delay and fuel preparation during the delay period as a function of volatility. More significantly, peak cylinder pressures need not be higher with very low ignition quality fuels (as classically expected) when the infection timing is reoptimised and therefore, do not automatically necessitate fundamental engine redesign. Maximum cylinder pressures observed with the DI diesel combustion system were of a level typlcal for tts type 1.e. 100-110 bar. Differences between fuels were not pronounced, all fuels generally belng within a 10 bar band. The higher cylinder pressures experlenced with this system compared with the IDI are to be expected considering the more advanced start of combustion typically required and the higher rates of infection. The similarility of peak firing pressures between fuels is again supported by the equivalence of ignition dolay across the range of fuels.

Measurement of nolse was. not 1ncluded as part of this contract. However, during the evaluation of each combustion system, subjective assessment was made of noise levels. Although such assessment is far from accurate (particularly with single cylinder engines), it $1 \mathrm{~s}$ felt that any comments made, together with interpretation of characteristics from the combustion pressure trace, are valuable in at least indicating where problem areas might ex1st.

The IDI combustion syster generally proved to be that with which subjective evaluation could most easily be made. It was generally assessed that the lower ignition quality diesel fuels increased noise relative to D2 at higher loads whilst the naphtha increased nolse towards light load. This generally correlates with observed higher cylinder pressures and rates of pressure rise at full load with the low Ignition quality diesel fuels, and higher rates of pressure rise at light load with the naphtha (Figure 34). Both broadcut fuels subjectively did not influence noise and this may have been inferred from the avallable peak cylinder pressure and rate

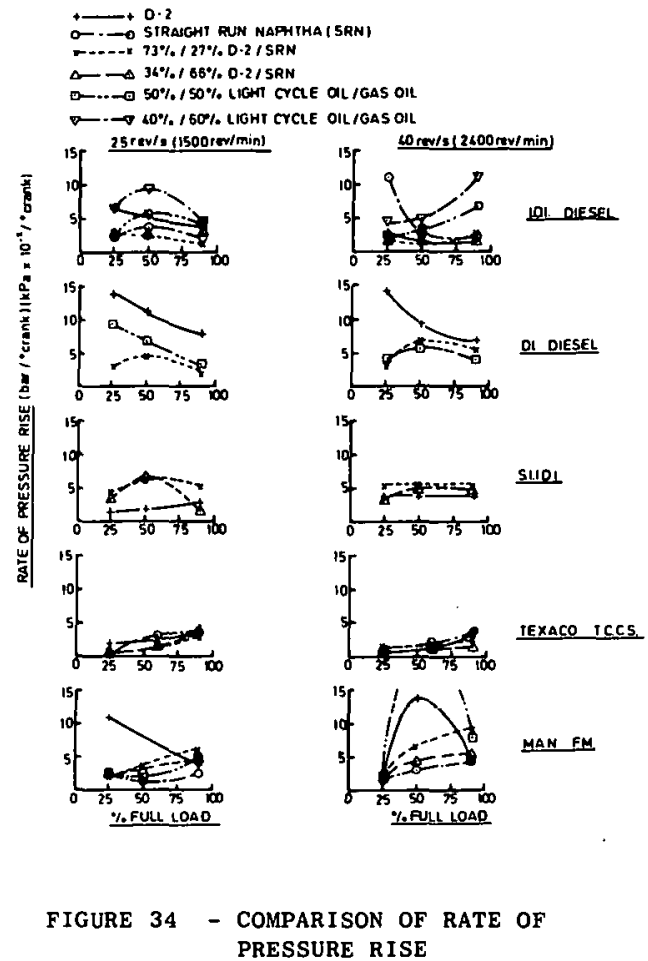

of pressure rise data.

In the case of the DI diesel, subjective noise was similar between fuels as may have been anticipated by the equivalent ignition delay periods and similar peak firlng pressures. Despite equivalent ignition delay, fuel effects upon rate of pressure rise were apparent. Across the load range, the highest rates of pressure rise were w1th the D2. The lower rates observed with the less volatile aromatic diesel fuel may have been projected based upon the Increased resistance of this fuel to mixing during the delay period. Conversely, higher rates of pressure rise may have been expected with the more volatile broadcut fuel. That this was not observed is not fully understood. Compared with the IDI diesel, the DI diesel exhibits higher rates of pressure rise across the load range. Compatible with higher cylinder pressures, this is as expected and primarily due to higher rates of injection.

The three spark 1gniced systems were all judged as producing lower noise levels than the IDI diesel, particularly in the case of the Texaco TCCS, where the low rates of pressure rise accounted for by the colncident spark and injection timing should be noted. Overall lower nolse will be assisted by the low peak firing pressure characterlstic of the spark ignited stratified charge engine. With these systems, nolse was also judged to not differentiate between type of fuel. Again this may be as expected, given the general similarity between firing pressures and rates of pressure rise. 
In the latter context, incidences of much higher rates of pressure rise were encountered in the FM system with certain fuels. These cases invarlably correlate with the lower volatility higher ignition quality fuels, but did not manifest in increased subjective noise. When considering the FM system, lowest rates of pressure rise were experfenced with naphtha when full spark control was always achleved. In this case the system exhibits pressure rise characteristics similar to the TCCS process.

Further comments on the subject of nolse are dificult in the absence of the more detailed measurements required for complete evaluation.

In the context of mechanical considerations, it should be noted that throughout the programme with all systems, no significant impact of fuel upon engine or fuel infection equipment deposits and or conditions were recorded. (With the exception of the naphtha and plug sooting problem prevalent in the SIIDI programme). Lubricating ofl condition was also unchanged. In making these comments, the short number of hours acrued on any fuel/engine combination must be taken into account.

\section{BASELINE COMPARISON OF COMBUSTION SYSTEMS}

This section has been included in order to enable direct comparison, between combustion systems, of overall performance and emissions levels. Since the IDI diesel is at present the most commonly used unthrottled, 11ght duty combustion system, it 18 generally regarded as the basis for comparison.

FUEL CONSUMPTION (FIGURES 35,36) - From the BSFC comparisons (Figure 35) it can be seen that the Texaco TCCS and MAN FM systems have comparable fuel consumptions at the lower load factors typically encountered during light duty operation. At these conditions, an advantage over the IDI diesel operating on D2 of from $7-15 \%$ at $40 \mathrm{rev} / \mathrm{s}$ (2400 $\mathrm{rev} / \mathrm{min}$ ) and up to $8 \%$ at $25 \mathrm{rev} / \mathrm{s}$ ( $1500 \mathrm{rev} / \mathrm{min}$ ) was evident. With increasing load the consumption trends of the FM do not show the sharp turn up seen with the TCCS and an advantage relative to the IDI is retained. The high load increases which penalise the TCCS are thought to be due to lower volumetric efficlency and the effects of colncident spark and injection timing on the degree of fuel preparation. The consumption advantage of these two systems are related to low friction, resulting from their relatively low compression ratio and open chamber design, rather than superior combustion efficlency, this being demonstrated by considering the counpärlsons of Indicated Spectfic Fuel Consumption (ISFC) (Figure 36). Th1s shows both systems to have Indicated consumptions worse than the IDI at all loads, and is particularly marked with the TCCS at higher loads for the aforementioned reasons.

Because of 1 ts open chamber design, the DI diesel is capable of a fuel consumption advantage of about $10 \%$ relative to the IDI diesel. A result of this is that its light load consumption is simflar and full load consumption superior to that of the open chamber stratifled charge englnes. This nrcurs despite higher friction levels and is a result of good combustion efficiency as demonstrated by the low ISFC apparent in Figure 36.
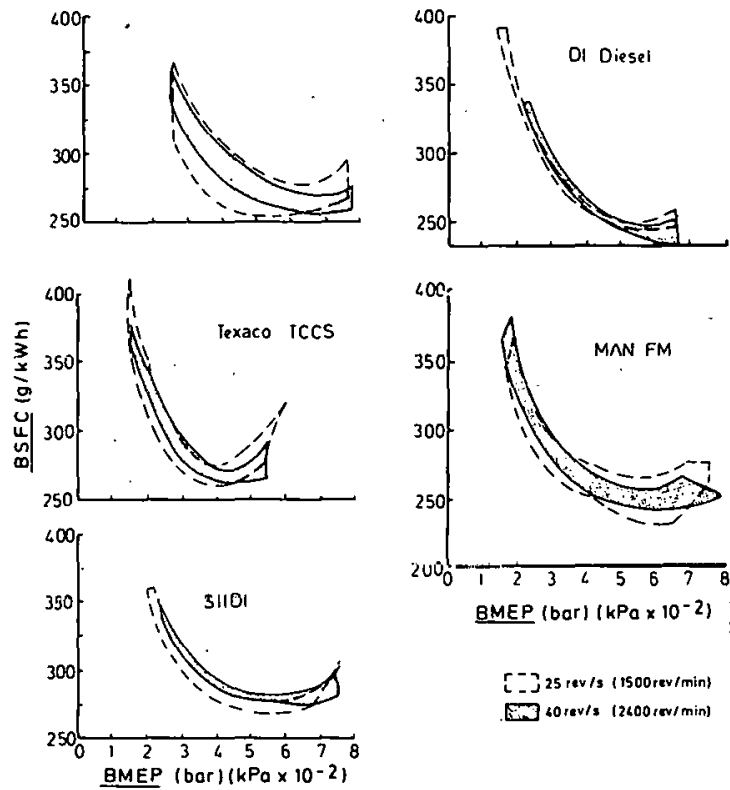

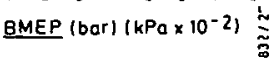

$[-]_{25} 2 \mathrm{rev} / \mathrm{s}$ (1500rev/min [E] 60 rev/s $(2600 \mathrm{rev} / \mathrm{min})$

FIGURE 35 - ENVELOPES OF BRAKE SPECIFIC FUEL CONSUMPTION - ALL FUELS

Although the SIIDI system does not demonstrate the light load consumption advantage shown to the open chamber stratified charge systems, levels are generally competitive with the IDI diesel at such loads. At higher loads however, consumption becomes worse than that from the IDI diesel. Although all the stratifled charge systems had similar compression ratios, the swirl chamber of the IDI system imposes a friction penalty relative to the open chamber systems. Because of th1s, it is unlikely that further development would result in the Indirect injection stratified charge concept achieving economy comparable to the open chamber systems. However, with further development, some luprovement over that shown here-may be possible by improving the I.SFC response.

COMPARISONS OF HC EMISSIONS (FIGURE 37) - The maint problem with the open chamber stratified charge system is light load HC emlssions. Irrespective of fuel type, the TCCS and FM systems enit much higher levels than the IDI diesel. Such levels require additional. emissions control such as cutalyata, thermal reactors etc., to meet US legislative 11mits. (Note that at $25 \mathrm{rev} / \mathrm{s}$ ( $1500 \mathrm{rev} / \mathrm{m} 1 \mathrm{n}$ ) the high light load HC response shown for the IDI diesel results from one fuel which approached misfirè. In general across all other fuels, the envelope was below 200-300 ppm). Between the two systems the FM has a general. 11ght load HC advantago over the TCCS. This is due to the use of a pintle injector instead of a plain hole type nozzle, the pintle improving the spray pattern at low fuelling levels. 

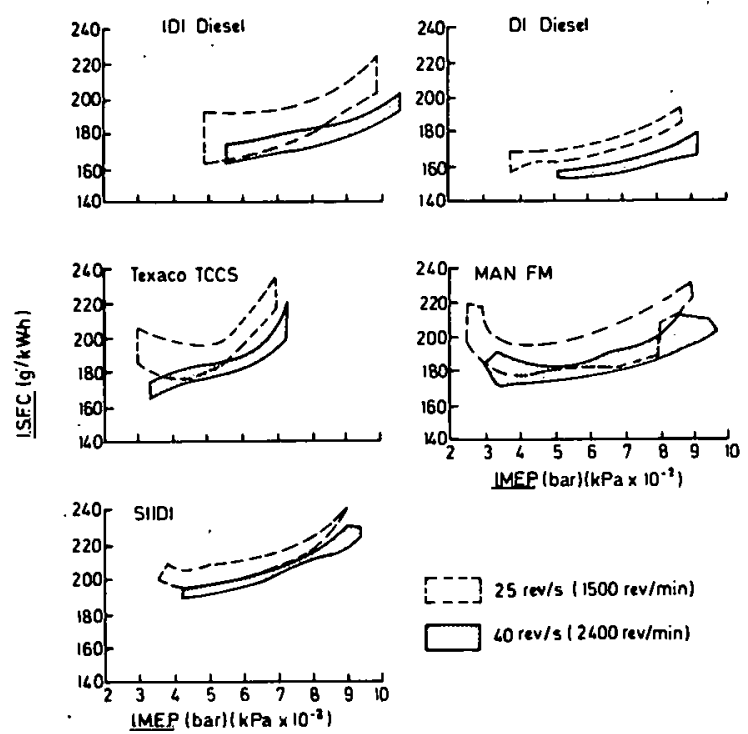

$[--] 25 \mathrm{rev} / \mathrm{s}(1500 \mathrm{rev} / \mathrm{min})$ $40 \mathrm{rev} / \mathrm{s}(2400 \mathrm{rev} / \mathrm{min})$

\author{
FIGURE 36 - ENVELOPES OF INDICATED \\ SPECIFIC FUEL CONSUMPTION \\ - ALl FUELS
}
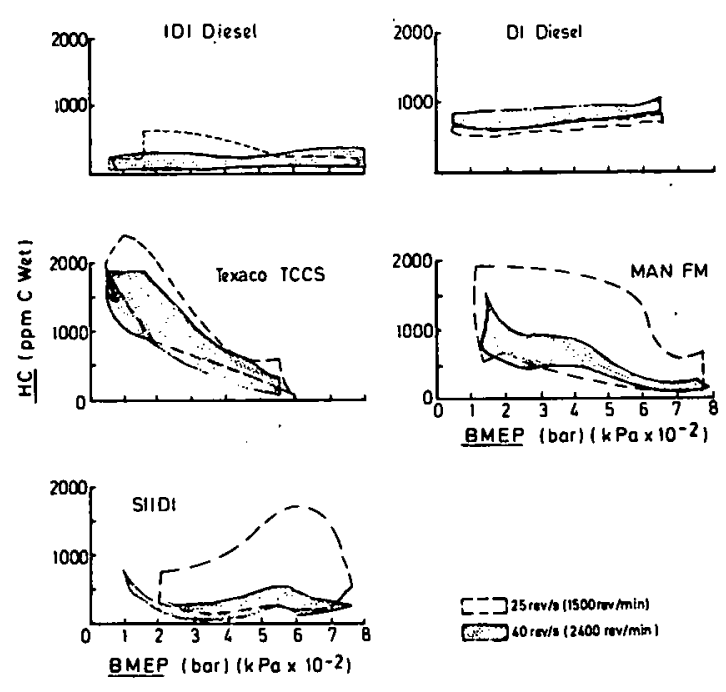

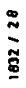

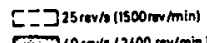

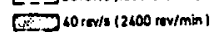

FIGURE 37 - ENVELOPES OF HC EMISSIONS - ALL FUELS
Additionally, the pintle infector does not have the sac volume penalties of the hole type nozzle with which 1t 18 known that the FM system enfts higher HC emisetons (7).

W1th the DI diesel, HC emfssions across the load range are 2-3. times higher than those of the IDI diesel. Whilet continued development of the multiple spray, 11ght duty DI diesel may reduce this penalty, the general level of emlssions will remain high due to the influence of the nozzle sac volume and the volume of the injector holes themselves. This problem is exacerbated with small cylinder sizes and can only be alleviated by the use of valve covering orifice (VCO) nozzles (13).

The SIIDI engine does not exhibit the same HC trends as the open chamber stratifled charge engines. In this case, the results as with the diesels are generally much flatter over the load range. W1th the exception of an uncharacteristically high response wh $D 2$ at $25 \mathrm{rev} / \mathrm{s}$ (1500 rev/min), the magnitude of HC emissions approaches those of the IDI diesel. At $40 \mathrm{rev} / \mathrm{s}(2400 \mathrm{rev} / \mathrm{m} / \mathrm{n})$ a sharp Increase at very light load causes HC emissions to be significantly higher than those of the IDI diesel. This trend would have been likely to have occurred at the lower test speed if operational problems had not 11 mbed the ayallable data.

COMPARISONS OF NOX EMISSIONS (FIGURE 38) - The NOX data, illustrates the classic differences between open and swirl chamber systems, 1.e. the marked falling response with owirl chamber englnes at high fuelling levels due to rich mixtures within the awirl chamber.

of the two open chamber stratified charge systems, the TCCS returns lower NOx enlasions than the FM at the lower load factors typical of light duty operation. Here, the TCCS system has a more retarded start of combustion than the FM when set for optimum economy and this undoubtedly assiste in suppressing NOx formation. At the higher load factors NOx enfssions are similar between the two systems and in this case the FM runs with a more retarded start of combustion. The fact that this did not curtall NOx emlssions in the FM is thought to be due to Nox formation befing exacerbated by the premixing of fuel and air before ignition which occurs in this system.

The FM results clearly indicate that baseline FTP NOx emissions would be higher than those for the IDI diesel. For the TCCS, with baseline NOx emissions lower than those of the IDI diesel at light load the system 18 considered to be likely to return more competitive urban driving cycle Nox emissions.

In the case of the DI diesel, emissions are considerably higher than those of the IDI diesel. These trends are due to the open chamber design in confunction with the requirement for a more advanced start of combustion and higher rates of injection. Towards the lighter loads, NOx enlssions with the DI diesel are also generally higher than those for the FM system and are undoubtedly exacerbated in this case by higher compression ratio and peak cylinder pressures. 

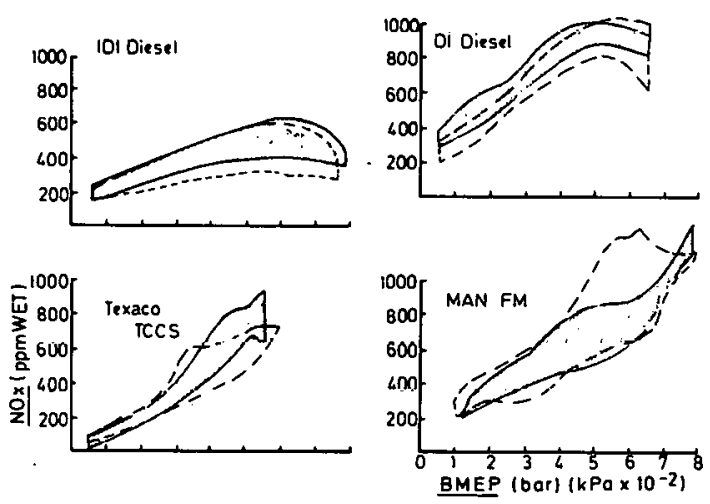
BMEP (bar) ( $\mathrm{kPa} \times 10^{-2}$ )
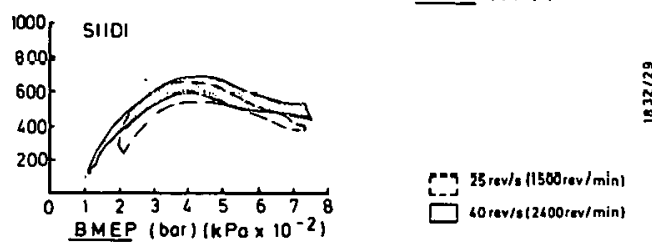

FIGURE 38 - ENVELOPES OF NOX EMISSIONS - ALL FUELS
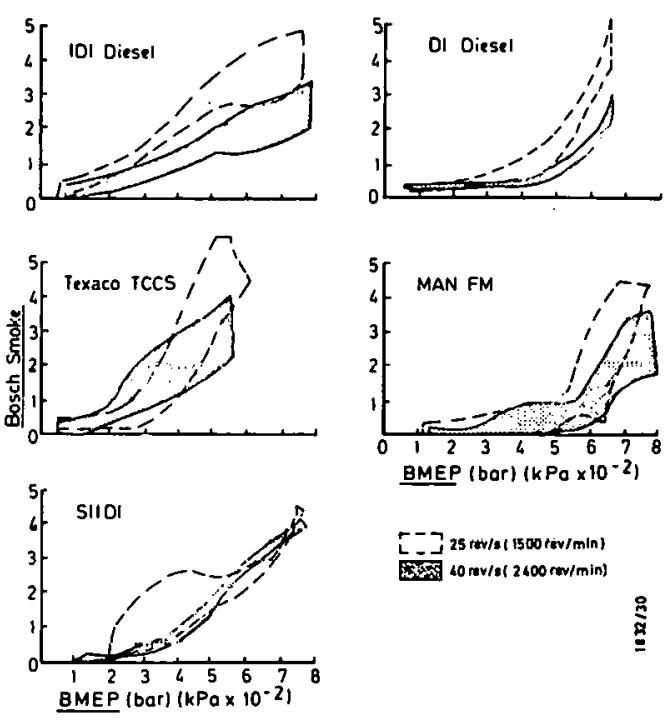

[-] 25 reth (1500 riv/mint $40 \mathrm{nv} / \mathrm{s}(2600 \mathrm{~cm} / \mathrm{min})$
FIGURE 39 - ENVELOPES OF EXHAUST SMOKE - ALL FUELS
Although operational problems in many instances precluded running at light loads with the SIIDI syster, avallable light load data and the trends of the remaining results suggest that low load NOx emissions do not present problems relative to the IDI diesel. NOx emissions at the highest loads also tend to equate to those of the IDI diesel. Throughout the middle of the load range, however, Nox emisaions are significantly elevated. Because of this, urban drive cycle NOx emissions would be expected to be high compared with the IDI diesel.

COMPARISONS OF EXHAUST SMOKE (FIGURE 39) - Regarding exhaust smoke, the baseline characteristics of the TCCS system demonstrate an early rising response with Increasing load, particularly at low speed, attalning high smoke levels compared with the IDI diesel at relatively moderate load factors. Th1s data supports comments made concerning the fuel consumption trends and the reasons discussed there are again applicable 1.e. lack of premixing and low volumetric efficiency. With the MAN FM system, smoke also turns, up sharply as critical alr/fuel ratios are approached but this occurs at much higher load factors owing to better alr utilization and higher volumetric efficlency. At the lower load factors this system exhibits very competitive smoke emissions.

With the DI diesel, low part load smoke levels compared to the IDI diesel can be achleved, but a sharp turn up is evident as critical a1r/fuel ratios are approached, particularly at low speed. Compared with the IDI diesel, the DI diesel fundamentally incurs greater smoke penalties at high fuelling levels due to the lower mixing rates limiting alr utilization. The increasing smoke responses shown here are, however, further exacerbated by the problems assoclated with matching the fuel injection equipment and levels of alr swirl over the wide speed range required for 1 fight duty applications.

The SIIDI engine generally enits comparable smoke levels to the TnI diesel with the exception of high load, $40 \mathrm{rev} / \mathrm{s}(2400 \mathrm{rev} / \mathrm{m} 1 \mathrm{n})$ when levels were higher:

COMPARISONS OF MAXIMUM BMEP (FIGURE 40) - These results show the maximum avallable BMEP envelopes over the speed range for each system across the range of fuels. Generally, the extent of these envelopes are constrained by exhaust smoke. Overall, the IDI diesel has the greatest torque potential followed by the FM, given low ignition quality fuels. The smoke trends of the DI diesel, Texaco TCCS and SIIDI systems significantly 11mit the maximum BMEP across the speed range, this being particularly pronounced in the case of the TCCS system.

COMPARISONS OF PARTICULATE EMISSIONS (FIGURE 41) At light load, particulate emissions for the SIIDI engine are broadly similar to those of the IDI diesel. At the higher load factors, the sygtem remalns competitive with the diesel at the lower speeds but incurs a penalty at the higher speed. This trend reflects the exhaust smoke relationsh1p. At light load, the MAN FM system can match the IDI diesel in respect of particulates on the lighter naphtha and broadcut fuels while penalties are 

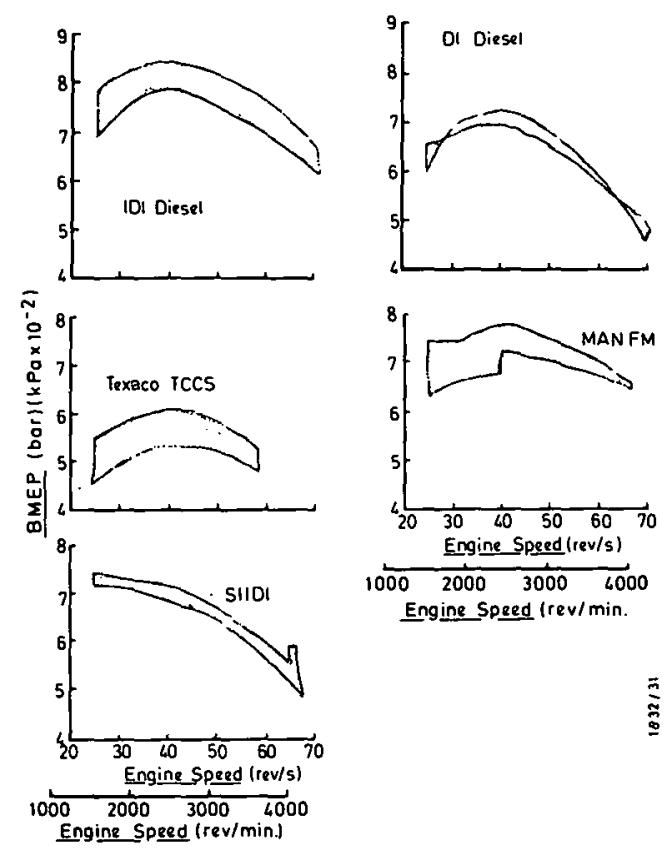

FIGURE 40 - ENVELOPES OF MAXIMUM BMEP - ALL FUELS

Incurred with heavier fuels. Particulate output is similar to the IDI diesel at high load factor.

W1th the ICCS system at 11ght load, volatile naphtha fuels enable particulate enissions approaching the IDI diesel to be achieved. Again large penalties are incurred with the heavier fuels. At high fuelling levels, the TCCS system exhlbits higher particulate enissions compared with the IDI diesel. Again this is pronounced with the heavier fuels. Between the open chamber stratifled charge engines, there 18 an overall bias in favour of the FM systent with respect to particulates, as is. expected from the comparative HC and smoke data.

At the higher test speed, particulate cmioolons utth the DI diesel were higher across the load range compared with the IDI diesel range. Such results are as expected when comparing the HC and sroke data between the two systems. At the 11ghter loads of the lower test speed, particulate emissions of the DI diesel more closely match those of the IDI diesel and in this case, the higher HC emissions of the DI diesel compared with the IDI diesel are counteracted by lower smoke levels. At high fuelling levels. however, the DI diesel emits more particulate mattor than the IDI diesel as the smoke advantage is eliminated and $\mathrm{HC}$ emissions remain high.

COMPARISONS OF CO EMISSIONS (FIGURE 42) - Figure 42 clearly demonstrates that all five combustion systems evaluated produce the low level of $C O$ expected from such unthroteled systems. All systems demonstrate increased levels at the higher load factors which, in sympathy with the smoke responses,
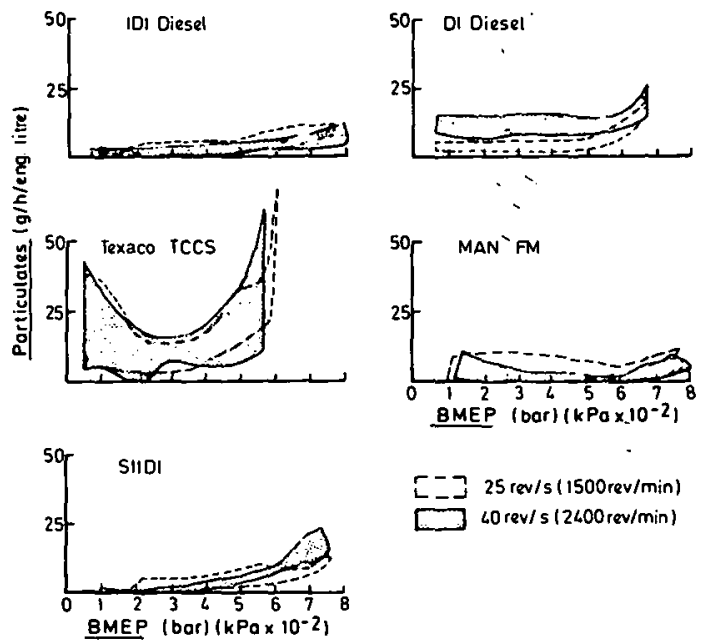

r-J $25 \mathrm{rev} / \mathrm{s}(1500 \mathrm{rev} / \mathrm{min})$ LC $40 \mathrm{rev} / \mathrm{s}(2400 \mathrm{rev} / \mathrm{min})$

FIGURE 41 - ENVELOPES OF PARTICULATE EMISSIONS - ALL FUELS
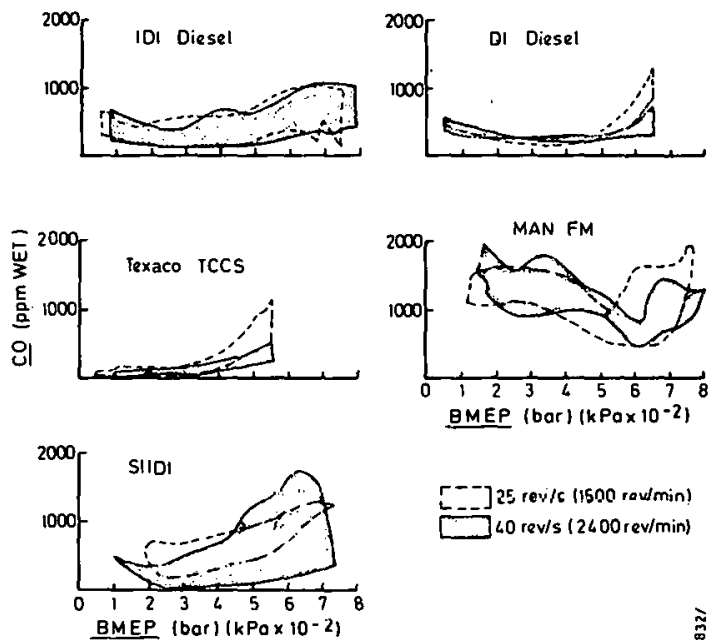

$\left.\mathrm{r}^{--}\right] 25 \mathrm{rev} / \mathrm{s}(1500 \mathrm{rav} / \mathrm{min})$
$-70 \mathrm{rev} / \mathrm{s}(2600 \mathrm{rev} / \mathrm{min})$ BMEP (bor) (kPo $\times 10-2)$ - ALl FUELS 
$\cdot$,
,,
,,

demonstrates the reduced avaliabllity of atr at the lower alir fuel ratios. The FM is alone, however, in also demonstrating an increase in Co towards light load factors. This trend is not seen with the other open chamber stratifled charge system.

COMPARISON OF TYPICAL FEDERAL TEST PROCEDURE (FTP) RESULTS - In this section, an approximate indication of the comparison of baseline FTP emissions results are given where data permits. This has been included to provide the reader with a fuller understanding of the Implications of the comparisons prevlously discussed. Owing to the scope of work of the contract, Insufficlent data was obtalned to enable confident predictions of FTP results using the proven simulation programmes avallable. The tabulated PTP results indicated here in Table 5 are based upon in-house experience. (IVI and DI diesel and MAN FM) and published information for the Texaco $\operatorname{TCCS}(i, 7,9,13)$. No vehicle data exists for the SIIDI system but the qualitative profections inarcated here are based upon the data acquired during th1s programme. When considering the NOx results shown, it should be remembered that operation with optimum economy timing plans are being considered and no emissions controls are assumed. Vehicles of 2500-3000 1b Inertia class form the basis for comparisons.

These trends agree with the previous comparative discussions based upon the results from this programme.

\section{GASEOUS EMISSIONS TRADE-OFFS}

Throughout the presentation of results from the
Fundamental study, thls report has been concerned solely with considering results with combustion ciming set to represent minimum fuel consumption. However, in order to generate these results, "off opt1mum" data was collected and is used here to support the main task objective by addressing the issue of lower NOx, as would be required in an emissions controlled environment.

In order to simplify the presentation of behavioural interactions the typical data shown in Appendix.7 indicates the variation of $B S F C, H C$ and particulate to a base of NOx enabling comparison of each variable at a given level of NOx. Collating the data in this form, although intitially confusing, does allow rapid assessment of the effects which result if lower NOx is required.

W1th three of the combustion systems, namely the TnT. diese1, the DI diesel and the Texaco TCCS, the existence of only one prime variable - injection timing - allows simple plots to be constructed for each fuel. These plots show for example, how hC varles with NOx variation resuleing from stmple timing changes, and are presented here at approximately $60 \%$ and $25 \%$ of full load at $25 \mathrm{rev} / \mathrm{s}$ (1500 rey/min). These operating condittons represent the region of operation for light duty applications responsible for a blgulficant proportion of the total FTP NOx production.

In the case of the MAN FM the existence of two prime variables - injection timing and spark timing required the adoption of a diferent testing strategy and also modifted the means of presentation.

TABLE 5

ESTIMATED FTP RESULTS WITH TEST ENGINES IN 2500-3000 LB VEHICLE

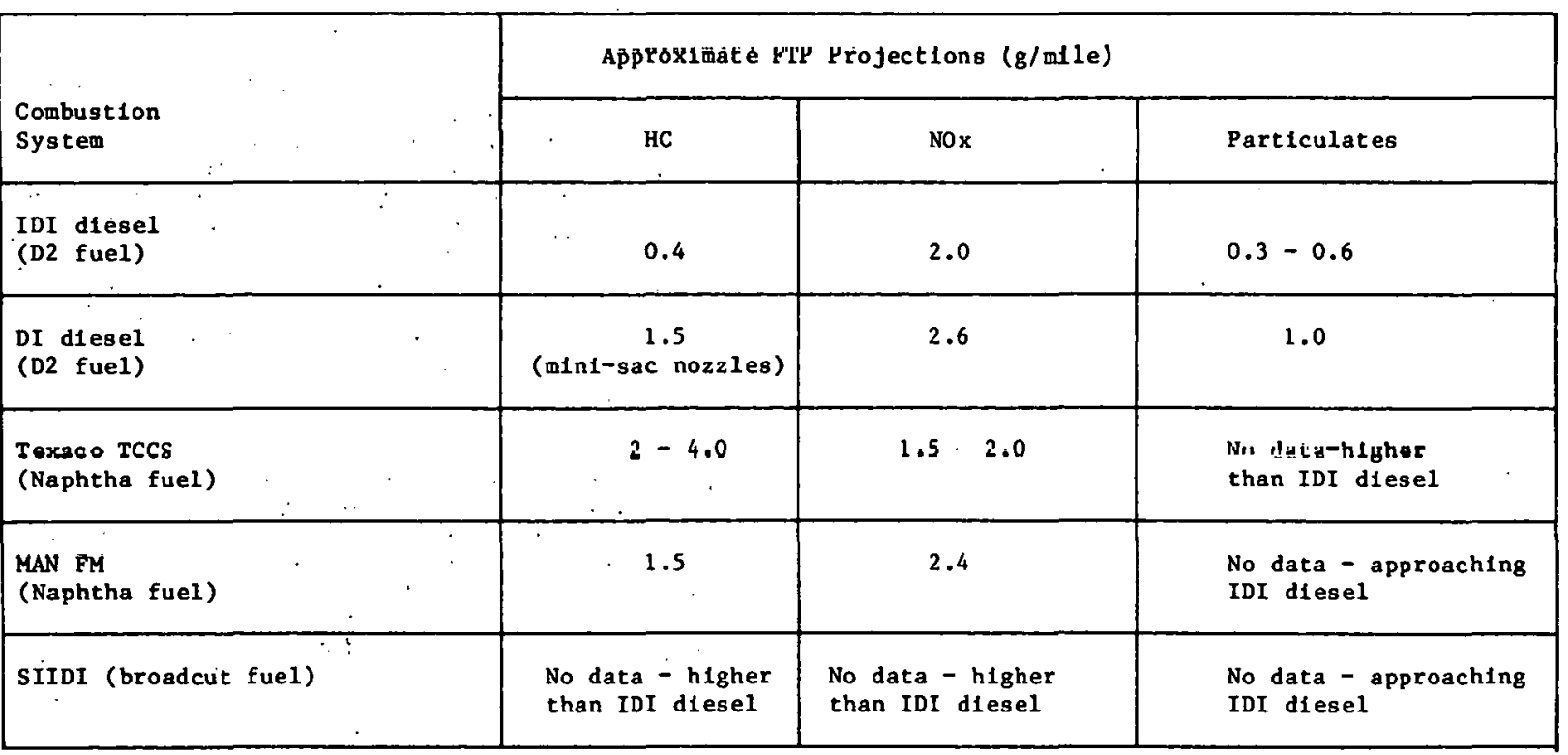


Having two prime varlables precludes the use of simple "advanced" and "retarded" evaluations owing to the infinite number of combinations of the variables. A technique of "matrix" evaluation was therefore adopted where, at certaln selected conditions (again approximately $60 \%$ and $25 \%$ full load at $25 \mathrm{rev} / \mathrm{s}(1500 \mathrm{rev} / \mathrm{mln})$ befng shown here), the range of acceptable spark timings was evaluated at each of three injection timings (one point in the matrix colnciding with a point previously evaluated, during the optimised minimum consumption tests and thus doubling as a repeatability check). The presentation of results thus gained is more complicated, and is therefore, shown as one fuel per figure, not as all fuels overlaid as with the other systems.

The mechanical problems which resulted in premature termination of test work on the SIIDI combustion system prevented similar einissions trade-off effects from being shown here.

From the data obtalned, certain observations are possible which are highlighted in the typical results presented. It was apparent, that across the range of fuels and combustion systems examined, Nox emissions could be controlled by rescheduling the timing plan. More significantly, classic trade-off characteristics generally exist across the range of fuels. Rather surprisingly, the low ignition quality fuels in the diesel engine at $11 \mathrm{ght} \cdot \mathrm{load}$, did not return significantly worse trade-off characteristics. This would not be expected to have continued however if lower NOx levels had been attempted, due to the earlier onset of misfire. The low 1gnition quality alternative diesel fuel did however return a markedly worse trade-off characteristic in the IDI diesel programe.

\section{DISCUSSION}

The IDI and DI diesel multicylinder screening tests generally demonstrated these systems to have a high degree of tolerance to the range of fuels examined. This was judged by the overall frequency and magnitude of adverse fuel consumption and emissions effects or other problems such as misfire, heavy knock, combustion instability etc., when compared to operation on a high ignition quality diesel fuel (D2). No attempt was made to optimize these systems for the alternative fuels but it should be remembered that observations were made under conditions of hot operation. It is accepted that addressing such issues as cold operation or rescheduled timing to achieve minfmum NOx may well Indicate reduced fuel tolerance.

Results obtained during the screening tests justified inclusion of the IDI and DI combustion systems in the fundamental programme where a much wider range of fuel specifications were adopted encompassing candidate fucls from a future syncrude industry.

During the fundamental programme, (still under hot operating conditions) the diesel systems again demonstrated good fuel tolerance. These results, and those from the spark ignited stratified charge systems are considered here in a discussion of the sultability of the various systems for light duty operation within potential future fuel groups.

\section{HIGH IGNITION QUALITY DIESEL FUELS}

Although such fuels, with cetane numbers of say 40-50 are not likely to be cost effective to manufacture in the long term, they are reviewed here to encompass the entire spectrum: Given fuels in this group, it is judged that the diesel engine will continue to dominate unthrottled automotive applications.

The IDI diesel benefits from a long history of development and is capable of relatively low baseline emissions, high torque and a wide speed range. Furthermore, it has already been demonstrated to meet current legislative standards.

In comparison, the light duty multiple spray DI diesel is in a much earlier state of development and at present exhibits torque, (see Fig. 40) emissions (see Table 5) and first cost penalties when compared to the IDI diesel. As compensation, and illustrating the reasoning behind the industry's efforts to develop the light duty DI diesel, it has In Its favour an economy advantage of typically $10 \%$ (see Fig. 35). This is of particular importance when related to offsetting the higher costs involved In producing high quality diesel fuels. However, if the DI is to be' competitive, the present developments with high pressure fuel injection equipment, unit injectors, variable nozzle opening pressure, valve covering orifice (VCO) nozzles etc., must be continued.

Reducing uncontrolled volumes at the infector tip has already proved beneficial in significantly reducing $H C$ emissions, particularly in englnes with small cylinder sizes, although the durability of the nozzle tip is currently a problem (Increasing the nozzle tip radius to improve durability increases the length of the nozzle holes effectively resulting In a trade-off effect between durability and HC emissions). It is. estimated that with continued development at optimum performance timing schedules, HC enissions could be reduced to levels approaching $0.4 \mathrm{~g} / \mathrm{mlle}$. This will encourage significantly lower particulate emissions. Problem areas will remain however. The smoke limited alr/fuel ratio will remain higher than that of the IDI d1esel, owing to the lower mixing rates, reșulting in a torque penalty. Furthermore, NOx levels will remaln high (typlcally $2.5 \mathrm{~g} / \mathrm{mlle}$ at optimum performance settings) owing to the more advanced combustion requirements, higher rates of injection and the open chamber design.

It Is belleved that the $H C$ and NOx enissions characteristics of the DI diesel syster, compounded by its particulate response will not, enable it to compete with the IDI diesel in a stringent emissions controlled environment. In this respect, it should be noted that even the IDI diesel in the heavier vehicle classes, will find proposed particulate standards difficult to achieve.

Developments with alternative DI systems, such as the MAN Controlled Direct Injection (CDI) system, 
remain as a means of preserving the $D I$ economy advantage whilst curtalling enissions problems. The CDI system, with pintle injectors and good air utilisation is capable of better baseline emissions and overall torque relative to the multiple.spray DI, whilst the use of lower pressure fuel injection equipment reduces the inftial cost penalty. Continued evaluation of other DI systems including fuel tolerance should therefore be encouraged.

of the stratifled charge systems examined, only the TCCS exhiblted the ability to run on high ignition quality diesel fuels. The SIIDI and FM systems evaluated in this study demonstrated problems due to uncontrolled combustion which significantly limited avallable speed range although such problems should be overcome by specifically directed development. Given high ignition quality diesel fuels however, such systems are unllkely to usurp the IDI diesel on the grounds of the signficant design and developinent effort required to enable thelr widespread adoption and to reduce torque and baseline emissions penalties. Indeed, the high HC characteristics of the open chamber stratified charge englne are unlikely to be overcome as these are thought to be inherent within the systems.

\section{STRAIGHT RUN NAPHTHA}

From the results obtalned, the IDI diesel combustion system cannot be ruled out as unsultable for operation on this fuel. Because of the previously discussed problems with the DI system whereby vapourization of volatile fuel fractions in the fuel injection equipment prevented testing, it is not known how the DI system would have behaved.

With the IDI diesel under hot runing conditions, levels of performance and emissions generally competitive with 1ts operation on D2 were evident, the only apparent problem areas belng HC emissions and light load economy at the higher test speed. However, concern must be shown over likely behaviour under cold operating conditions. Although during this programme instant starting, with the ald of a glow plug, followed by maintenance of a misfire free 1dle was achleved down to ambient temperatures of about $15^{\circ} \mathrm{C}$, it is not anticlpated that starting and Idling at signiflcantly lower temperatures would be achieved.

Nolse $1 \mathrm{~s}$ also $11 \mathrm{kely}$ to present a problem and furthermore, 11ght load operation with cold intake alr would result in further problems due to increased misfire and white smoke. Retarding for low NOx would significantly exacerbate the latter, and would certainly require accurate timing modulation. Accurate timing modulation will also be required to avoid light load misfire at rated speed. 'In addition, the tolerance to signticant degrees of retard may remaln suspect even under hot running conditions, where it is expected that the late combustion resulting from both the retard and the low ignition quality of the fuel would induce further problems with misfire, white smoke, HC and particulates. It is therefore believed that if the IDI diesel is to be considered a viable system when operating on this fuel in an emissions controlled environment, then the use of retarded timings alone to reduce Nox may not be practical. However, the use of exhaust gas recirculation (EGR) in conjunction with advanced timings as required to achleve best light load trade-offs may enable significant NOx reductions to be achleved without inducing the above mentioned penalties. It should be noted that EGR is required for NOx suppression in the heavier vehicle classes irrespective of fuel.

For the IDI diesel to operate on low ignition quality fuels such as naphtha, such features as continuously energlzed heater plugs, increased exhaust back presure and ceramic insulation should be considered in order to improve cold operation. Further increases in compression ratio are not considered viable since the high levels currently used for cold starting, etc. already impose problems during manufacture and have detrimental effects with respect to reducing air utilisation and increasing frictional losses.

Desplte these suspictions and based upon the characteristics observed in the IDI diesel with fuels of this class, it is considered that continued evaluation should be carried out in confunction with approprlate development, addressing cold operability in those areas discussed. The objective of this unrk shnuld he to axaming the nugrall cultability of the IDI diesel with such fuels, including tolerance to NOx control (recard and EGR). Such programmes (running simultaneously with further development of the potential of the stratified charge engines) should be encouraged, since the obvious alternative of adopting spark ignited stratifled charge engines would result in torque and baseline emissions (particularly HC) penalties.

The spark ignited stratified charge engines, because of their positive 1gnition overcome problems relating to cold operation with low ignition quality fuels. This has been demonstrated previously $(1,17)$. They are thus, obvious candidates for operation with naphtha type fuels.

The sparking plug sooting problems encountered with the SIIDI system when operating on naphtha prevents comment on this system here. However, previous experlence with a comparable system operating on gasoline suggests that such problems are not Insuperable (4).

Both the TCCS and FM open chamber systems were successfully evaluated and demonstrated part load economies superior to the IDI diesel. While the FM demonstrated lower HC, smoke and particulate emissions, and superior high load consumption and avallable torque than the TCCS, the latter system is seen to be more competitive as in terms of NOx and Ilght load economy, particularly at low speed. Although the data apparently suggests that the FM is the better overall candidate, the following factors should be considered.

Firstly the FM data shown is derived from single cylinder tests. Whilst suttable friction levels have been adopted during analysis to enable comparison. with the multicylinder TCCS engine, it should be noted that the results could well be enhanced by the lack of cylinder to cylinder variation of air swirl, air flow, injection and spark timing. In part related to this was the good 
volumetric efficlency of the FM compared to the poor breathing characteristics of the White TCCS engine. The apparent performance advantages of the FM towards high load are thought to be encouraged by these factors. The light load $\mathrm{HC}$ and particulate advantages observed are, however, thought to be genulne benefits resulting from the use of a pintle injector and representing a significant advantage relative to the TCCS given the high light load HC characteristics of the open chamber system.

Secondly, the FM system is more demanding in its requirements for the relationship between the start of injection and ignition and a sultable compromise will be more difficult to obtain. It is, however, satisfled with a significantly less demanding ignition system than the TCCS.

Therefore, before a candidate between these two systems is selected, it is considered that continued studies should be carried out with the objective of comparing well developed multicylinder versions of each.

The spark Ignited stratifled charge combustion systens should, with approprlate development, be significantly more tolerant to being retarded for reduced NOx than the diesel systems when considering naphtha type fuels. It has also been shown that they respond favourably to EGR for. NOx control $(1,4,7)$. The value of these combustion systems for low Ignition quality fuels and conditions of stringent emission controls cannot, therefore, be ignored. of the systems evaluated however, each must be controlled from a relatively high emissions baseline when compared to the IOI diesel. In the case of the open chamber TCCS and FM systems in particular, control measures such as catalysts will be required to combat the high light load HC emissions which will tend to become even more problematical when controlling NOx. Further measures such as light load throttling and Insulated manifolds and exhaust ports will also probably be required to encourage catalyst light of $f$. These extensive emission controls will, however, tend to erode the baseline consumption advantages of the open chamber systems.

Although, as previously mentioned, the SIIDI system was not evaluated with the naphtha, work with the low Ignition quality broadcut fuels indicate that this system has the potentlal for lower HC emisstons than the open chamber systems. Further work to evaluate this combination of fuel and combustion system would be of value, therefore, since overall, trade-off problems at low Nox levels may be curtalled due to the lower HC baseline.

\section{HIGH IGNITION QUALITY BROADCUT FUELS}

Baseline results obtained with the high ignition quality $(40 \mathrm{CN})$ broadcut fuel indicate that diesel englnes are entirely sultable. This is judged from the similarity in performance and emissions characteristics between the broadcut fuel and the regular D2, the only signficant exception to this being the higher low speed, light load fuel consumption demonstrated by the IDI diesel on this fuel. This similarity has been demonstrated with little concession to optimization, leaving scope for possible Improvements with redefined fuel injection equipment, combustion chamber geometry, swirl characteristlcs etc.

However, when considering controlled enissions the multiple spray DI diesel again ceases to be competitive for the same reasons outlined during the discussion of high ignition quality diesel fuels.

The tolerance of the IDI diesel to belng retarded for NOx control with these fuels will need to be investigated while the response to EGR will also need consideration for the heavier light duty vehicles. Preliminary examination of the limited clming response data obtained during the IDI programme suggests that the trade-off relationship betwen HC and NOx is no more severe with this fuel than w1th the D2.

Severe problems with cold operation are not anticipated with such fuels in the IDI diesel; since US light duty diesels are already developed to utilise D2 fuels down to this ignition quality. It is likely however that accurate timing modulation, (within the scope of developments in the fleld of electrontc fuel injection equipment), will be required to avold starting and light load problems when retarded for low NOx. For those classes of vehicles requiring EGR to control NOx, the use of advanced injection timings to achieve the best $11 \mathrm{ght}$ load trade-offs should again prove beneficial in avolding similar problems.

By suppressing smoke formation in the IDI diesel, the high ignition quality broadcut fuel demonstrated the ability to reduce particulate output relative to D2 fuel. This is a notable result given the problems facing the light duty diesel with respect to particulate emissions legislation. With higher volatility and lower aromatic content, high ignition quality broadcut fuels have much in common with the low particulate fuel champloned by GM (18).

of the spark Ignited stratifled charge englnes the MAN FM system examined here was unsultable for fuels of this class due to uncontrolled combustion which restricted tts speed range. Again, detalled development for single fuel operation can moderate this problem. The SIIDI and TCCS systems did, however, prove to operate successfully within this fuel group. Given the previous comments concerning the IDI diesel and those in the earlier section dealing with the advantageous position of the diesel systems operating on high ignition quality diesel fuels, it is not considered that spark ignited stratifled charge englnes will be utilized on a wide scale for fuels of this class.

\section{LOW IGNITION QUALITY BROADCUT FUELS}

Like naphtha, this class of fuel with relatively low ignition quality ( $35 \mathrm{CN}$ ) again makes for a difficult definitive judgerent regarding candidate combustion systems. Once again, the IDI diesel cannot be dismissed on the evidence of this programme, 1ts performance and emissions levels generaliy remalning competitive with D2 operation. However, doubts remain concerning cold operation, noise and tolerance to retard. 
The spark lgnited stratifled charge systems are naturally sutted to fuels of this type, although the open chamber systems still retain thetr high HC characteristics and lower torque potentials. The SIIDI system ran successfully exhlbiting the expected HC advantage over the open chamber systems, although levels were overall stlll greater than with the IDI diesel. Again as expected the fuel consumption of the SIIDI system was worse than demonstrated by the open chamber systems.

For the same reasons as previously discussed with naphtha fuel, work should continue examining whether the IDI diesel can be adopted for such fuels (cold starting, low NOx, etc.,) in order to utilize its superior baseline performance and enlssions characteristics. Concurrent with this, comparison of well developed multicylinder versions of the spark Ignited systems evaluated should be addressed.

\section{LOW IGNITION QUALITY DIESEL FUELS}

In previous sections of this discussion dealing with low ignition quality fuels, the data obtained within this programme has indicated a requirement for continued work with the IOI diesel to see whether it can be adapted to utilize its baseline torque and emission potentials. With fuels of this category, the IDI diesel demonstrated problems in respect of distinctly inferior starting, at relatively high amblent temperatures, in addition to problems experienced and related to regimes of misfire and HC penalties at low speed.

In view of these operational problems, spark 1gnited stratifled charge englnes seem attractive for fuels of this class. Of the open chamber systems evaluated here their reduced torque avallability and environmental penalties were still evident. Because of this and despite the operational problems observed with the IDI programne, the overall torque potential and baseline emissions characteristics of the IDI system with fuels of this class are thought to again provide incentive for examining whether the IDI can be adapted. Such programmes should be concurrent with continued multicylinder stratified charge engine studies, Including the SIIDI system not covered here with this. class of fuel.

Although the DI diesel demonstrated a greater degree of tolerance than the IDI diesel with this fuel category (better starting, no misfire) simllar Incentives for development are thought to be less apparent for two reasons. Firstly, the system retalns high basellne emisslons characterlstics and secondly, the DI has lower torque potential than the IDI, a situation which is exacerbated at low speed with fuels of this class.

\section{CONCLUSIONS}

Based upon the results from this programme and the discussions formulated, the following conclusions are drawn complementing those reached on completion of the Task 1 Literature Study (1).

1. The swirl chamber IDI and multiple spray DI diesel systems examined proved to be fuel tolerant, demonstrating the abllity to be successfully evaluated over a wider range of fuels than had been anticlpated. The concept of fuel tolerance was augmented by the fact that significant detrimental effects relative to the baseline performance and enissions characteristics with $D 2$ fuel were not generally apparent.

2. As expected, spark Ignited stratifled charge engines are capable of. operation over a wide range of fuels. The MAN FM and SIIDI systems evaluated here proved intolerant however to fuels with high cetane ratings, although it is anticipated that this could be overcome by detalled development. The Texaco TCCS operated successfully irrespective of fuel type.

3. Of all the combustion systems examined, the IDI diesel returned overall superior baseline torque and emissions chàráčéristićs irrespective of fuel type.

4. For future high ignition quality diesel and broadcut fuels, the diesel englne is expected to renain dominant for light duty applications. Despite an economy advantage of typically $10 \%$ the multiple spray DI diesel will not compete with the IDI diesel given that current US enissions standards are not relaxed.

5. The observed overall baseline torque and emission advantages of the IDI diesel dictate that concinued evaluacion should be carried out to ascertain whether it can be adapted for successful cold starting and running, acceptable nolse and the attalnment of low Nox (retard and/or EGR) with low 1gnition quality naphtha, broadcut and diesel fuels. of these, it is anticipated that the latter w111 be most problemat1cal.

6. With positive Ignition, scope naturally exists in respect of operational characteristics for stratified charge englines with future low ignition quality, low octane fuels. Concurrent with the continued evaluation of the IDI dlesel, comparisons of well developed, mult1cylinder stratified charge engines must be undertaken if overall cholce of a candidate system is to be made.

7. Irrespective of fuel, open chamber stratified charge engines (MAN FM and Texaco TCCS) exh1b1t baseline emlssions penalties, particularly of HC, and significant control measures will be required. This problem is reduced in the FM system by the use of pintle injectors although NOr emioolong are higher. In the absenec of high octane fuels, torque levels equivalent to the IDI diesel are unlikely to be attained although consumption advantages are possible.

8. Development of the swirl chamber spark Ignited engine may alleviate the HC penalties characteristic of the open chamber systems. Consumption advantages are however lost and torque and NOx emission penalties relative to the IDI diesel remaln. 
9. The interaction between fuels and engines is complex. Much more work, Including the assessment of other combustion systems and actual synfuels must be. undertaken for a full understanding.

\section{RECOMMENDATIONS}

Based upon the results from this programe, the following areas of further work are recommended for a full understanding and to enable more accurate Judgement of combustion systems for future fuels. They are based upon structured experimental programmes utilizing candidate synfuels.

1. Identify matrix of likely future fuels, including synfuels, and the means for making them available in sufficlent quantities for test programmes.

2. Using selected candidate fuels, continue to examine the IDI diesel with particular regard to cold operation, notse and the luw NOx potentlal (retard and/or EGR).

3. Using selected candidate fuels, continue to evaluate the light duty DI diesel particularly as Its development status evolves.

4. Obtain comparisons between well developed, multicylinder spark Ignited stratifled charge englnes covering both direct and indirect injection. Include cold operation, nolse and emission control potential.

5. With the most promising combustion systems for specific fuel groups give wide coverage to alternative cylinder sizes and speed ranges. Include naturally aspirated and turbocharged comparisons.

6. Carry out extensive optimization programmes for specific fuel groups utilizing the most promising combustion system concepts.

\section{ACKNOWLEDGEMENTS}

The authors gratefully acknowledge the assistance provided by British Petroleum Research Laboratorles for the detalled fuel analyses and blending, Flat VI and MAN for their input in respect of the IDI diesel and FM combustion systems respectively and the cooperation of White Englnes Inc. and Texaco for guidance with the TCCS phase of the programme.

\section{RF.FF.RF.NGF.S}

1. The Tnfluence of Fuel Varlables on the Operation of Automotive Open and Pre-chamber Diesel and Spark Ignited Stratifled Charge Engines:

A Literature Study Covering Petroleum and Syncrude Dertved Fuels.
Ricardo Consulting Englneers plc,

Report DOE/CE/50021-1, Dept. of Energy Contract DE-AC01-80C\$50021, September 1980.

2. A Universal Test Engine for Combustion Research.

French, C.C.J. SAE 830453 .

3. Notes on a Meeting held between the DOE and Ricardo in Washington on $13 / 14$ th February, 1980 .

Needham, J.R.

Unpubltshed Ricardo Internal Report DP 80/353, March 1980 .

4. A New Stratifled Charge Engine Based on the Ricardo Comet Design.

Overington, M.T. and Haslett, R.A.

I. Mech.E. C253/76, 1976.

5. Design and Evaluation of a stratified Charge Multifuel Miltary Engine.

Mitche11, E. et al

SAE 680042

6. H1gh Speed, Multifuel Engine; L9204 FMV

Urlaub, A.G. and Chrela, F.G.

SAE 740122

7. 'FM' - A High Efficiency Combustion System for the Future Light Duty Engine?

Norris-Jones, S.R. and Russell, J.T.

SAE 820760

8. Sofim New Diesel Motorization for Motor Cars and Light Industrial Vehicles.

Torazza, G.

A.T.A. June 1978 pp 21.

9. The High Speed Direct Infection Diesel for Passenger Cars.

Monaghan, M.L.

SAE 810477

10. Identification of Probable Automotive Fuels Composition: $1985-2000$

The Southwest Research Institute

Report HCP/W3684-01/1 US DOE Contract No. EY-76-C-043684, May 1978.

11. Motoring Friction Data from Light Duty IDI Diesels 
Glover, A.R.

Unpublished Ricardo Internal Report DP 81/S18, 1981 .

12. Reducing Hydrocarbons and Odour in Diesel Exhaust by Fuel Injector Design

Ford, H.S. et al

SAE 700734

13. The Development of the Ricardo 1800 HSDI $80 \mathrm{x}$ 89 Four Cylinder Direct Injection Diesel Engine. Phase 1. Passenger Car Callbration Tests.

Tugnett, $\mathbf{R}$.

Unpubl1shed Ricardo Research Repurt DP $81 / 1612$ Santombar 1981.

14. Effect of Diesel Fuel Properties on Emission and Performance

Broering, L.C. and Holtman, L.W.

SAE 740692

15. A Study on the Reduction of NOx of Diesel Engines

Murayama, T. and Tsukahara, M.

Bulletin of the JSME, Vol. 20, Number 150 , December, 1977.

16. The Effects of Diesel Fuel Properties on Performance, Smoke and Emissions

Gross, G.P. and Murphy, K.E.

ASME Publicat1on Number 78-DGP-26, 1978.

17. A Stratifled Charge Multifule Military Englne A Progress, Report

M1tche11, E. et al

SAE 720051

18. Prospects for Diesel Passenger Cars and the Need for an Improved Fuel

Dimick, D.L.

API Automotive and Industry Forum January 23rd 1980 . 


\section{APPENDIX 1}

BRIEF HISTORY AND DESCRIPTION OF COMBUSTION SYSTEMS EVALUATED.

\section{INDIRECT INJECTION DIESEL}

The combustion system adopted for use during this programme was the Ricardo Comet V. The Ricardo Comet swirl chamber since its conception some fifty years ago has had a history of continued development and the Comet $v$ system is now widely adopted for light duty applications.

Figure 1 shows diagramatically the general arrangement of the system. The maln chamber/swirl chamber volume ratio is maintained typically at $1: 1$. The shallow main chamber within the piston crown is connected to the swirl chamber via a tangential throat. During compression, intense organised alr swirl is Induced within the swirl chamber by the throat. The fuel is injected near to top dead centre into this air swirl and the combustion intitated by self ignition of the fuel after a relatively short delay perlod. In the later stages of combustion, the expanding gases exit the throat at high velocity and combustion is completed within the main chamber above the plston, rixing with air in the process due to the design of the cavitles within the piston crown.

Load factor is governed by the quantity of fuel injected and the torque curve is smoke 11 mited.

This arrangement results in good air utilization and enables wide speed ranges to be adopted. Because of heat losses assoclated with the throat, compression ratios are high, typically 20-23:1 to assist starting and maintain combustion under cold, light load conditions. Starting is further alded by the electrically heated glow plug protruding into the swirl chamber.

\section{DIRECT INJECTION DIESEL}

Traditionally, the direct injection diesel has primarily been utilized in the automotive fleld for medium and heavy duty truck applications. By virtue of 1 ts open chamber design, fuel consumption gains relative to the indirect Injection diesel are achleved and because of this the direct injection concept has been researched in recent years for light duty automotive applications. The focus of this research has primarily involved matching the fuel and ulr inlxing characteristic over the wide speed range required for light duty applications. This is more difficult in the direct infection engine owing to the lower mixing rates encountered and ultimately requires high fuel line pressures and injection rates coupled with detalled optimization of the nozzle flow area.

The light duty direct infection system evaluated during this programme and shown schematically in Figure 2 was designed and developed by Ricardo and adapted from an existing indirect injection diesel eng1ne. The system was procured for research into the potential of the light duty, automotive direct injection engine and has been subject to some 2 - 3 years development. This development programme is still on-going.

The system utilizes a re-entrant torold as a combustion chamber within the piston crown. The reentrant chamber for such applications provides superior performance over a wide speed range compared with the parallel sided chambers Invariably utilized for medium/heavy duty ápplications.

Swirl within the incoming air in induced by the geometry of the inlet port and is magnified as the air is forced into the combustion bowl during compression. Close to top dead centre, fuel is injected and ignited by self lgnttion after a short delay period. In this design, multiple fuel sprays (four) are utilized which are radially distributed around the combustion chamber to augment the fuel and air mixing processes.

The englne evaluated here utilized injector nozzles incorporating minimized sac volumes to curtall $\mathrm{HC}$ and particulate emissions. The compression ratio of 20:1 ensures that good starting and light load running characteristics are achleved. At such compression ratios, additional starting aids are not required. The compression ratio is higher than that of the medium/heavy duty direct injection engine owing to the adverse surface to volume relationship when considering appreclably smaller cylinder sizes.

Load factor is solely controlled by the quantity of fuel infected and the torque curve is smoke limited." With high injection rates and relatively more advanced starts of pressure rise for optimum performance compared with the Indirect injection diesel, the direct injection diesel is characterized by higher rates of pressure rlse and peak firing pressures.

3. ŚPARK IGNITED INDIRECT INJECTION COMBUSTION SYSTEM

For this programme a spark Ignited variant of the Ricardo Comet $V$ swirl chamber system was ut111sed.

The main parameters of the Ricardo comet $V$ design (as described earlier) are retained for this engine but the compression ratio is reduced to 12:1 from typically 20-23:1 for diesel applications. The swirl/main chamber ratio is held as close to $1 ; 1$ as possible. The major changes are that the injector is relocated to provide a horozontal spray axis and a sparking plug with extended electrodes has been fitted to the original injector position. 
In the latter half of 1970, Ricardo explored the potencial of this combustion systen as the basis of an unthrottled stratifled charge erigine with multifuel capability. Utillsing a single cylinder engine of $85.1 \mathrm{~mm}$ bore and stroke, approximately 100 different engine bullds were examined. The varlous paraineters studied included injector position, spray type, sparking plug position and size, main chamber/swirl chamber volume ratio, compression ratio, throat slze, rate of injectlon, nozzle opening pressure and fuel type. These development programmes have been reported and the general arrangement evolved is shown in Figure 3.

Fuel is injected near to top dead centre in the rapidly swirling alr generated by the throat leading to the swirl charber. Fuel is evaporated and mixed with the air, creating an ignitable mixture at the sparking plug which is timed to spark at a suitable interval after the start of injection. The kernel of flame caused by the spark develops until there is an appreciable change in the cylinder pressure. with gasoline as fuel, thls flame front expands throughout the swirl chamber until it is quenched by high local AFR or contact with the chamber walls. With diesel fuel, as the flame develops, the self ignition temperature of the Euel is reached and at a number of sites autoignition occurs. The combustion gases then leave the swirl chamber through the throat at high velocity and combustion is completed within the main chamber, mixing with air in the process due to the design of the cavities within the piston crown.

As wth the IDI diesel englne, load factor is governed by the quantity of injected fuel and the torque curve is smoke Iimited.

\section{TEXACO CONTROLLED COMBUSTION SYSTEM - TCCS}

The TCCS stratifled charge combustion process has been under development now for several years. The finally evolved form of the system Is shown schematically in Figure 4. Englnes typlcally have compression ratios of $12: 1$.

In the TCCS syster, high intensity air swirl is generated within the cylinders by the inlet port. This swiri is magnifled at TDC by the bowl-in-piston arrangement. Fuel is injected, mixes with the swirling air and is carrled over the sparking plug positioned adjacent and downstream of the injector. The inftial portion of fuel adtitced to the cylinder is ignited by the spark which in multifuel applications. Is timed coincident with the infector opening. The burning zone formulated between the spark plug and injector is then fed by fresh fuel from the injector, which controls the rate of combustion, and by alr due to the induced swirl. The fuel injection rate and level of alr swirl must be closely matched to ensure that the flame netther extinguishes nor burns over-rich resulting in carbon formation. The englne load is solely governed by the quantity of fuel injected which also affects the duration of combustion.

As for the diesel engine, the power output of the TCCS process is smoke 1 inited.

Thls system has been applied to cylinder sizes between $82.6 \mathrm{~mm}$ and $146 \mathrm{~mm}$ but most of the more recent developrent has been restricted to the smaller sizes for light duty applications.

\section{MAN FM COMBUSTION SYSTEM}

The MAN M system has been successfully utll1zed for multifuel applications owlng to the unlque MAN design philosophy of spraying the fuel directly onto the walls of the combustion chamber as a thin film. The rate at which fuel evaporates from the wall is controlled by piston temperature and di: swirl. Th1s enables rates of pressure rise to be moderated with low cetane, high octane gasoline fuels by only permitting relatively small controlled quantities of fuel to be premlxed during the inevitably longer ignition delay period.

To reduce ignition delay with high octane gasolines, MAN ralsed compression ratios to beyond 20:1 resulting in unacceptable nechanical stresses. To alleviare this problem whilst still retaining multifuel capability, a sparking plug was added to the combustion chamber of the $M$ system and the compression ratio suitably reduced. The spark ignited development is designated the FM.

In the FM syster, shown in Figure 5, high intensity alr swirl is induced by a helical inlet port and the spherical combustion chamber within the piston crown. During compression, fuel is sprayed via the pintle infector nominally onto the wall of the combustion bowl. The high levels of air swirl assist with spreading the fuel over the chamber wall as a chin fllw thus mintalniug excellent sharge stratification. Heat supplied to the fuel film by the plston and air charge causes evaporation. The evaporated fuel is then mixed with air and carrled to the sparking plug where ignition occurs or 1nto the established flame path following ignition.

As per the diesel engine, the maximum torque output of the FM syste is sthoke limiced assuming detonation does not occur. Load factor is controlled by the quanticy of fuel injected.

To date, the majority of FM applications have been to heavy duty size englnes of approximately 102-127um bure and 1-1.6 11Lres per cylinder with rated speeds of 2200-3200 rpm. Some applications to light duty displacements of approximately 0.62-0.66 11tres per cyllnder have however been made. Ricardo have gained recent experience with high speed FM engines of cylinder sizes within the range $0.41-0.49$ 11tres.

Multifuel FM engines operate with compression ratios of typlcally 15.5-17:1, the higher level 
being of value in enabling the system to operate as a conventional diesel $M$ syster without spark should diesel fuel he avallahle. Gasoline (80-100 octane), JP-4, dlesel fuel and diesel zasoline mixtures have all been successfully used with such compression ratios.

For optimized operation with 91 octane gasoline, Ricardo experfence with small high speed FM engines revealed that compression ratios of 13-14 were requited to avold full load detonation. This value closely approaches the optimum balance between Indicated thermal efficlency and mechanical friction. As discussed in the main text of this report the compromise compression ratio of $12.5: 1$ utillzed during this programme was blased by the inclusion of the low octane naphtha fuel. 


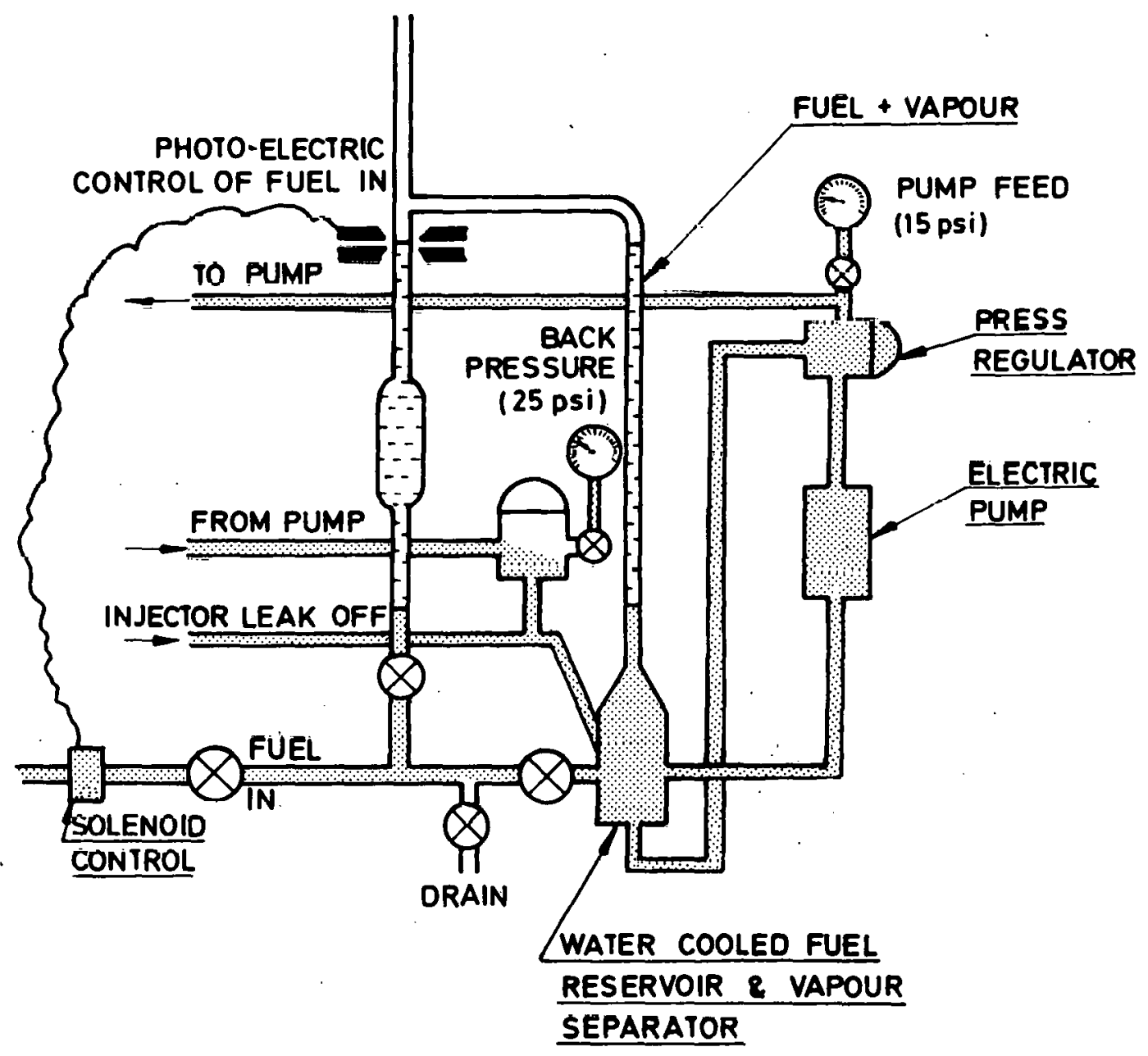


CONVERSION OF GASEOUS EMISSIONS DATA FROM VOLUMETRIC TO SPECIFIC GRAVIMETRIC UNITS

Where readers may wish to convert data from the volumetric units ( $\mathrm{ppm}$ ) as presented to specific gravimetric units ( $\mathrm{g} / \mathrm{kW} . \mathrm{hr})$ the following approximation may be used:

$\mathrm{g} / 1 \mathrm{~W} \cdot \mathrm{hr}=\mathrm{ppm} \times(($ BSFC $\times$ BMEP $)+($ Volumetric Efficlency $\times$ 433.8)) Const. $x$ BMEP

where

$$
\begin{array}{ll}
\text { BSFC } & \mathrm{g} / \mathrm{kW} \cdot \mathrm{hr} . \\
\mathrm{BMEP} & \mathrm{bar} \\
\text { Volumetric Effictency }= & \% \\
& \\
\text { Const. } & 2088954 \text { for HC } \\
& 1034965 \text { for CO } \\
& 629743 \text { for NOx }
\end{array}
$$

Since volumetric efficiency data has not been presented during this report, the attached figure gives bands showing the range observed with each combustion system during the programme. The necessarily approximate nature of this presentation does mean that conversion will not be fully accurate, but $1 t$ does enable a general appreclate of the levels concerned to be galned.
APPENDIX 3 BANDS OF OBSERVED VOLUMETRIC EFFICIENCY,

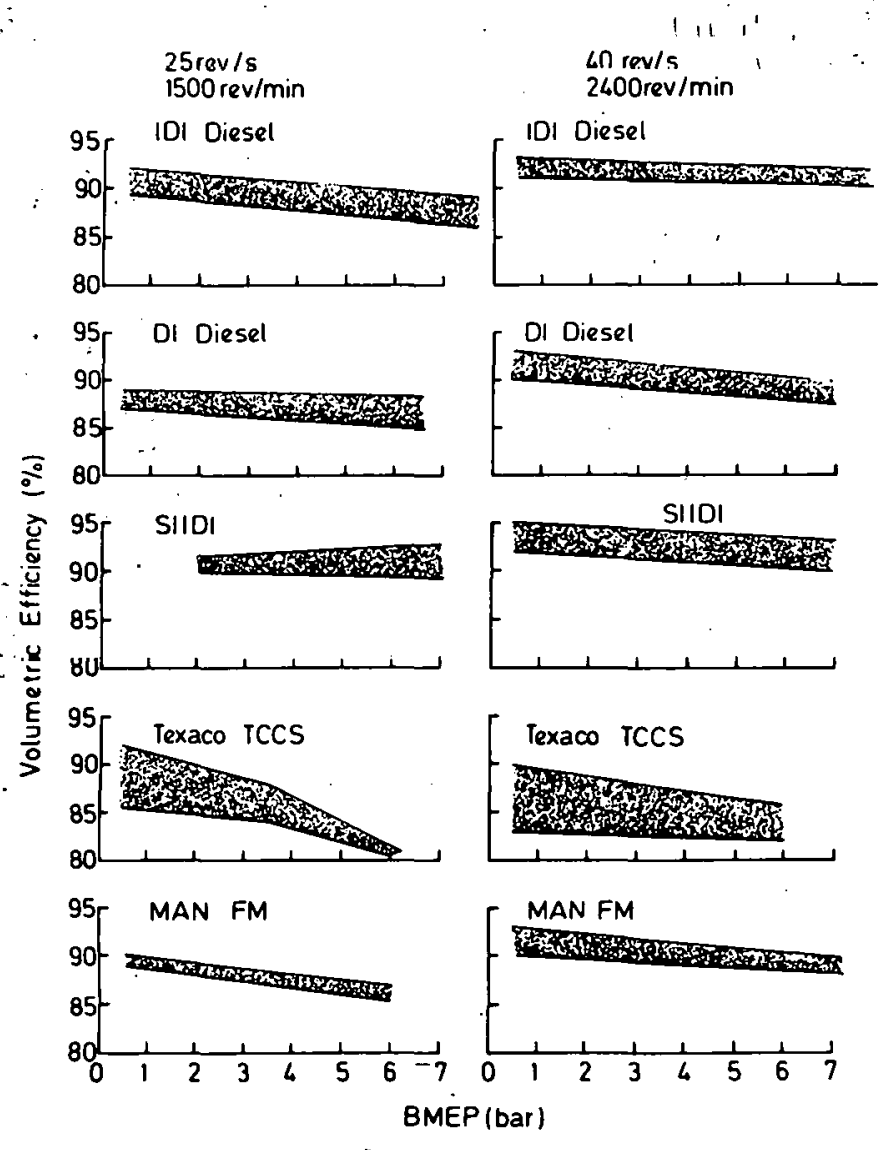


APPENDIX 4a-1 IDI DIESEL CONTOUR .

MAP OF BSFC $[\mathrm{g} / \mathrm{kWh}]$

PHILLIPS D2 REFERENCE

IUEL :

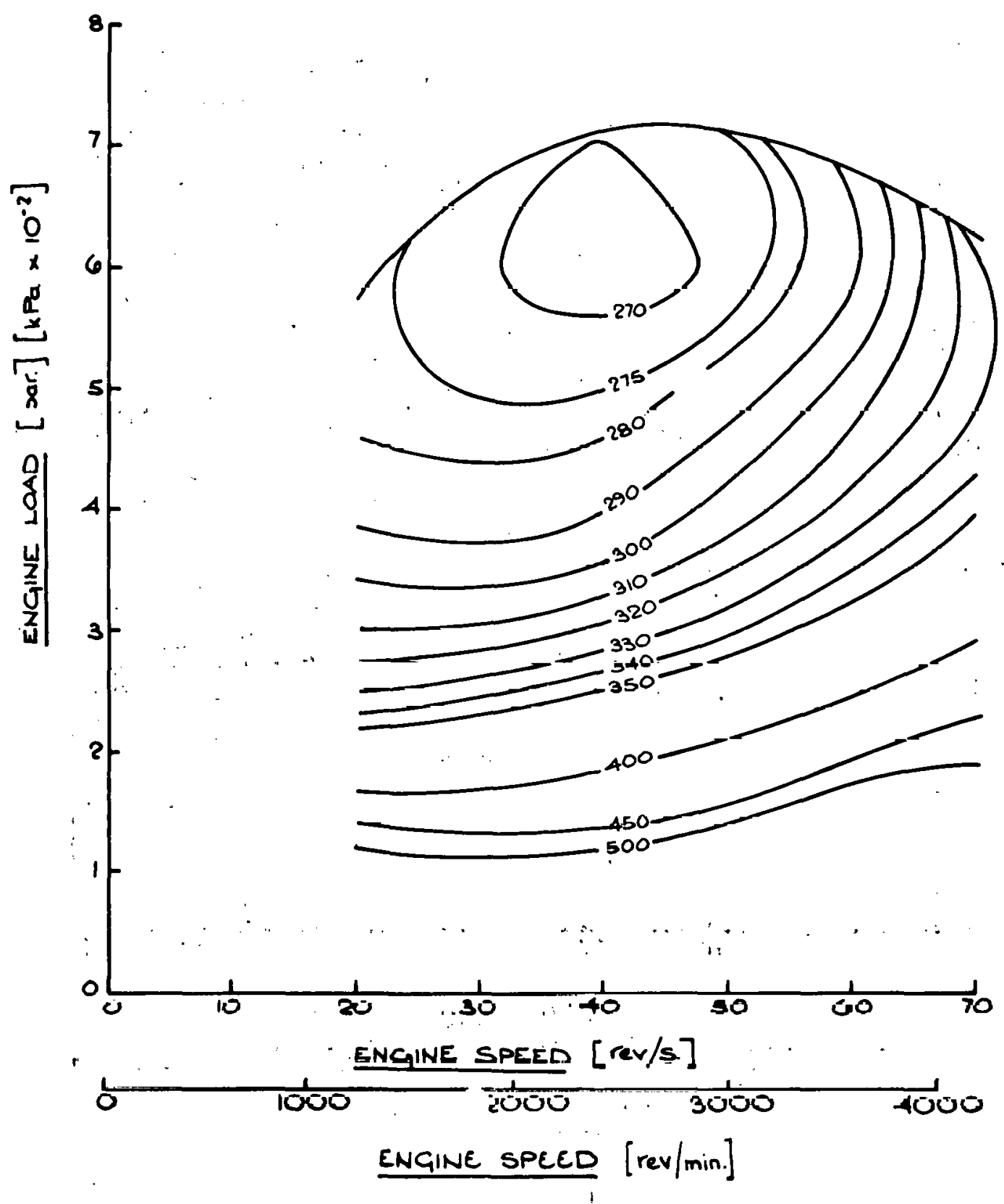




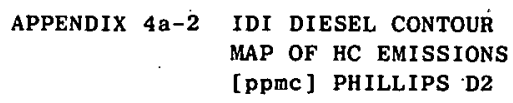

[ppmc] PHILLIPS D2

REFERENCE FUEL

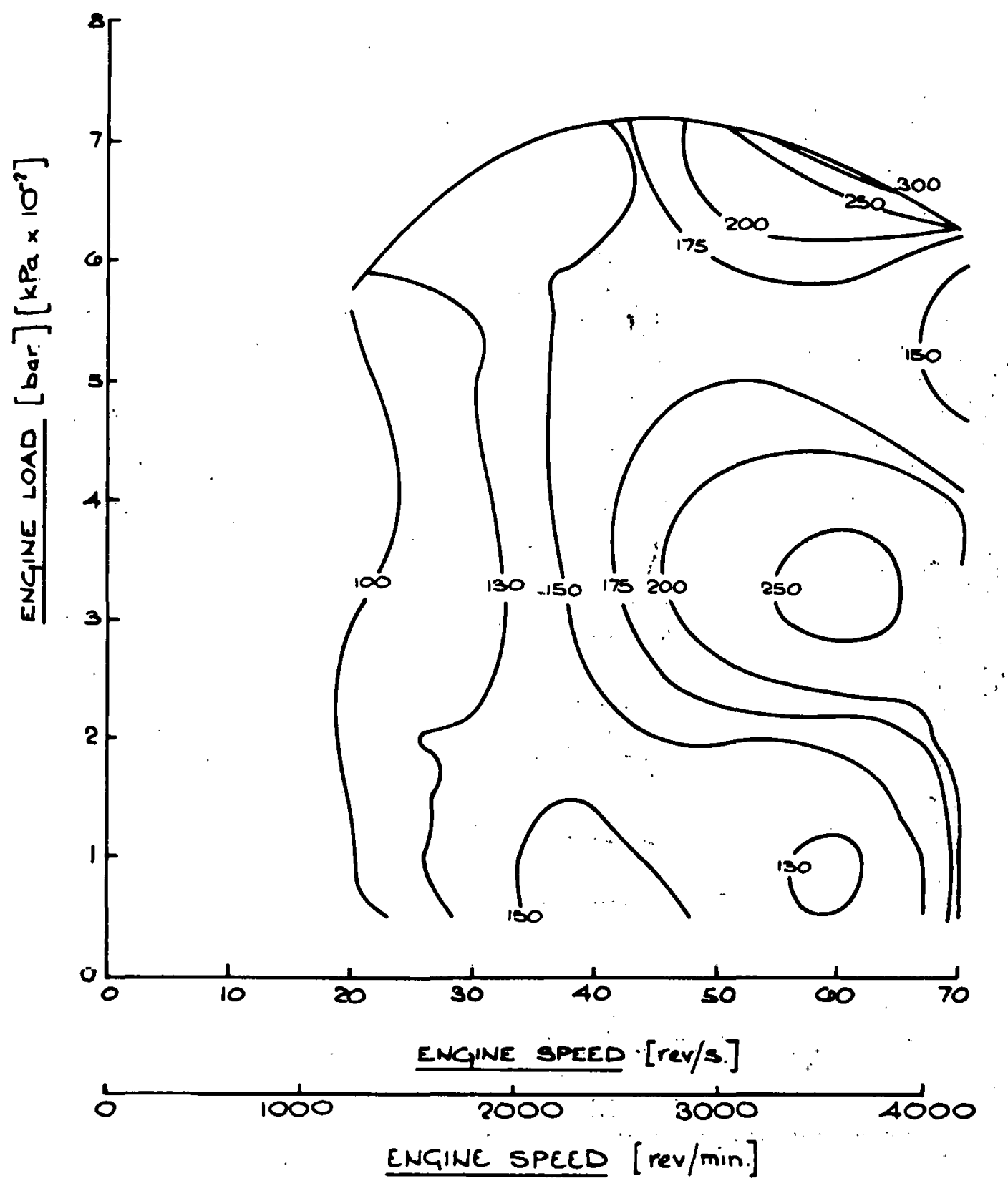




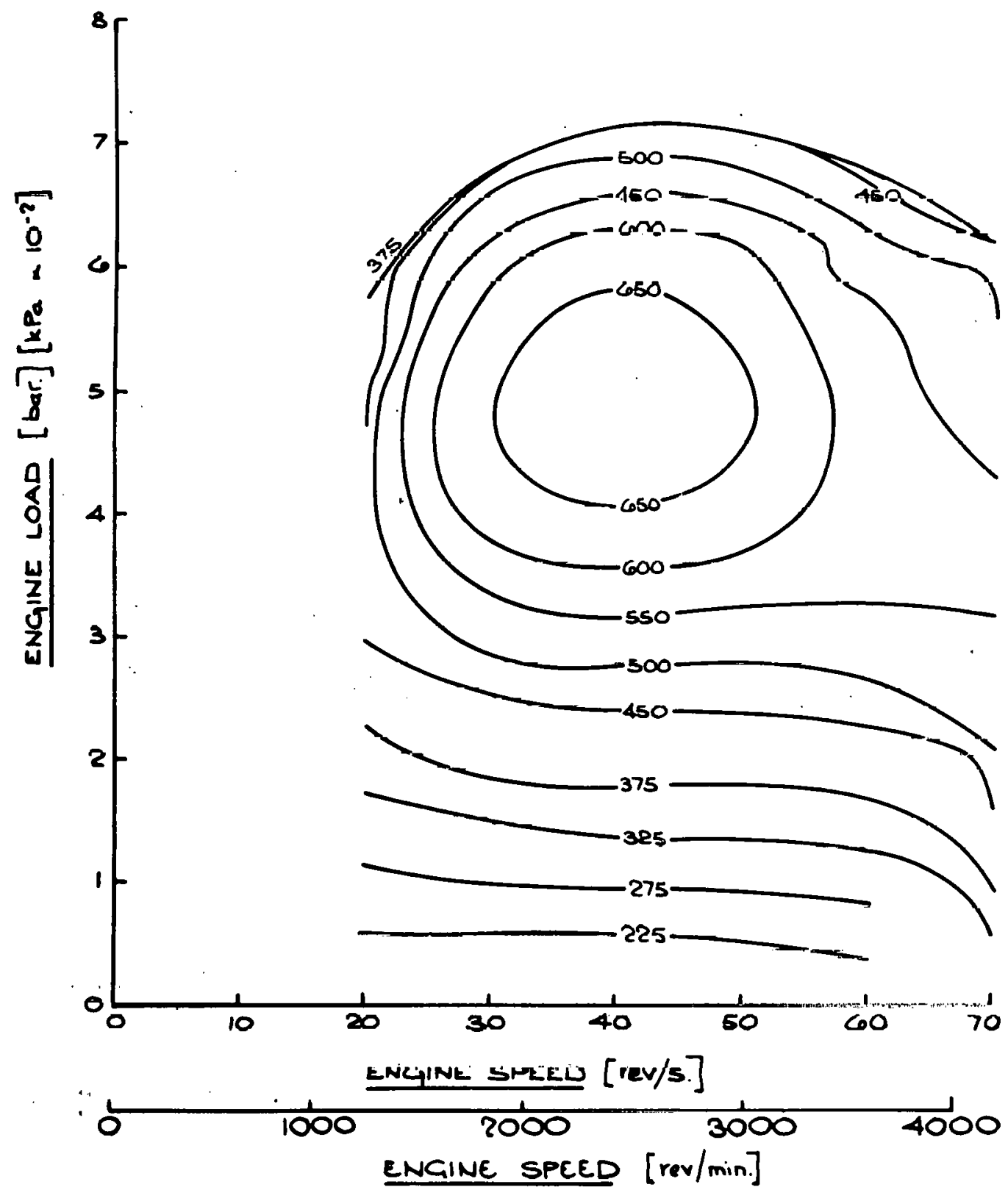


APPENDIX 4a-4 IDI DIESEL CONTOUR MAP

OF CO EMISSIONS [ppm]

PHILLIPS D2 REFERENCE

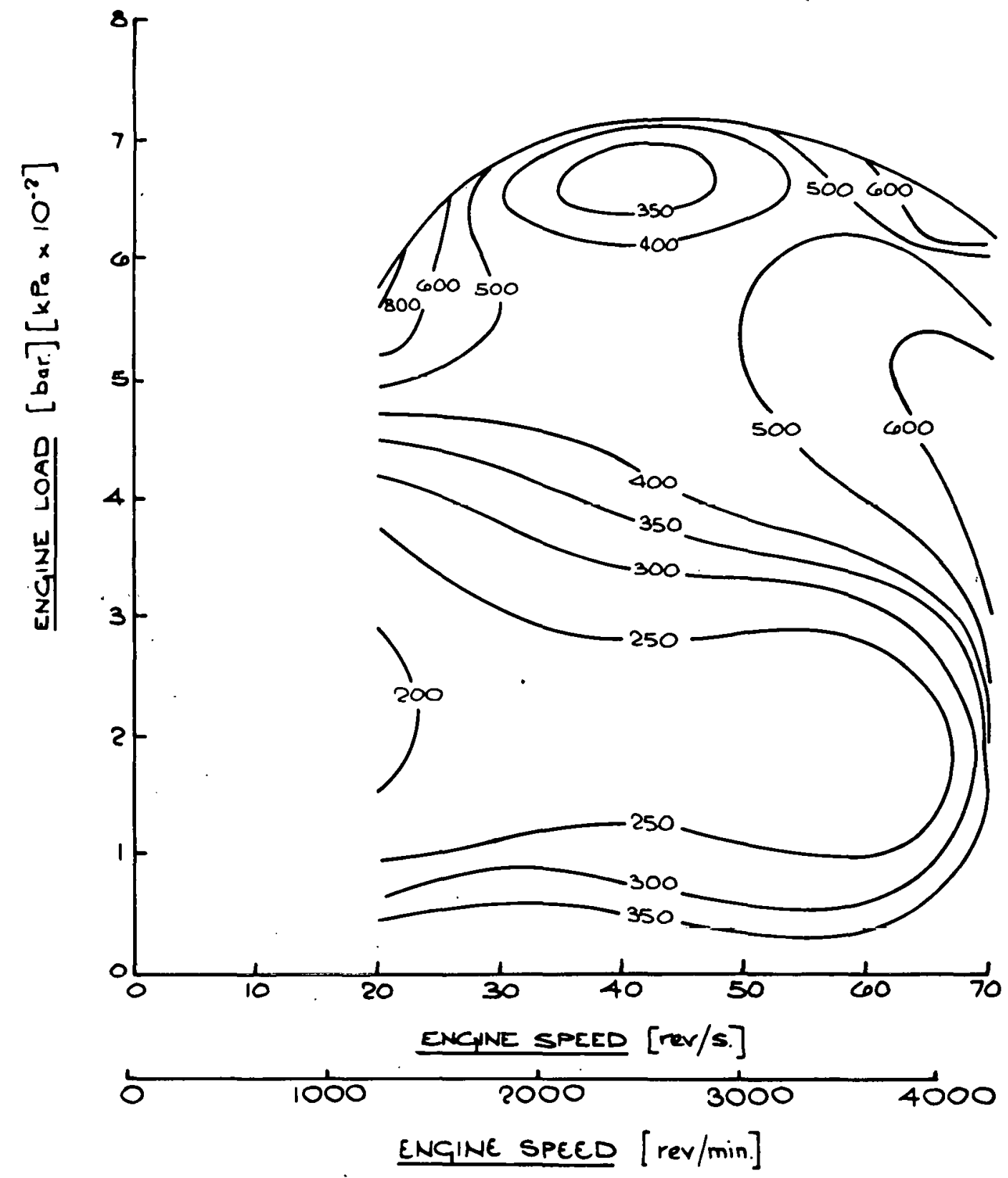


APPENDIX 4b-1: DI DIESEL CONTOURIMAP.:

$\because 11+1, \cdots O F$-BSFC' $[\mathrm{g} / \mathrm{kWh}]$ PHILLIPS

$\because: \because * \because$ i. D2 REFERENCE FUEL

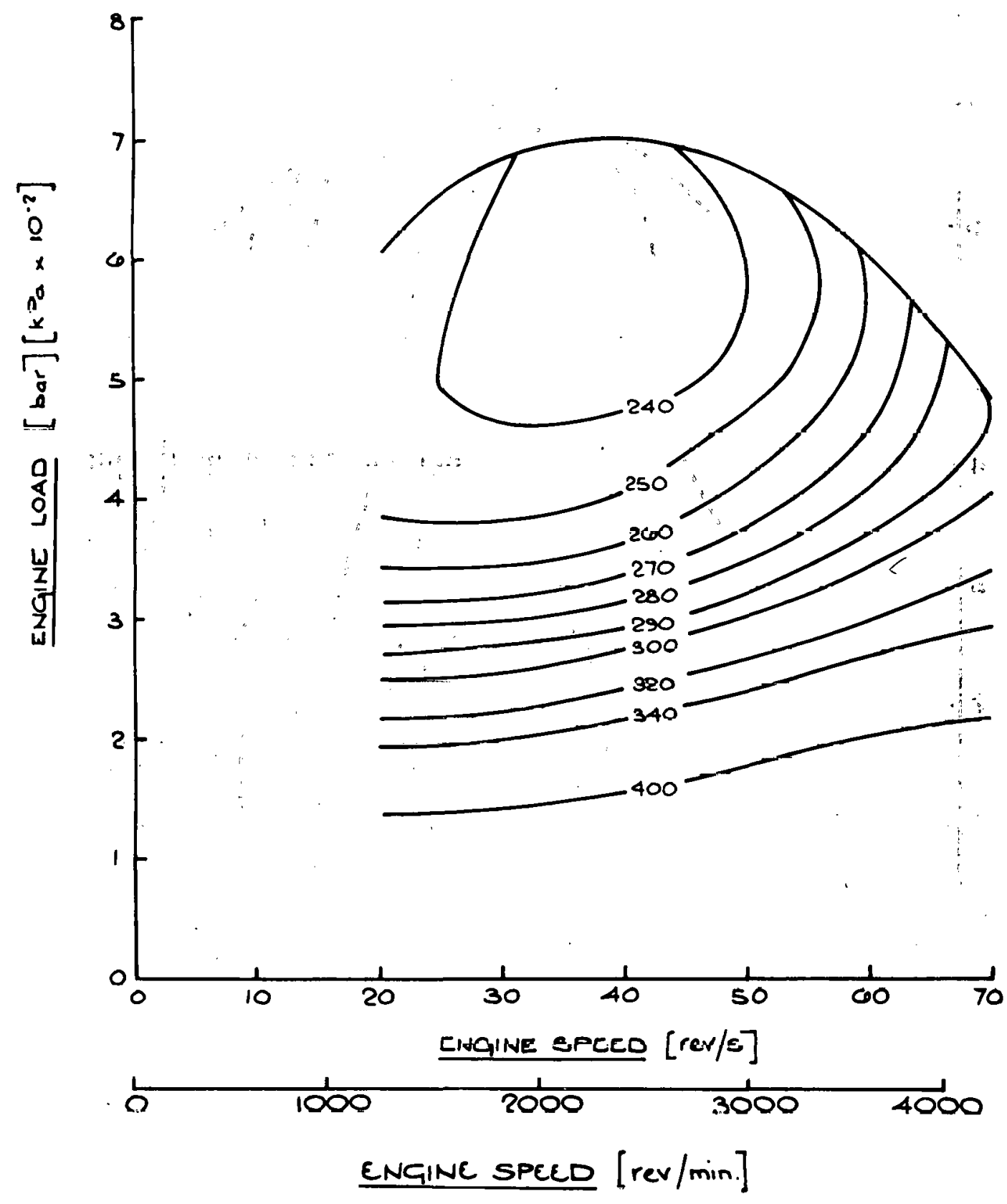


APPENDIX $4 \mathrm{~b}-2:-$ DI $=$ DIESEL CONTOUR MAP $:$,

$\therefore$ I $\mathrm{r} \cdot \therefore$ OF HCIEMISSIONS [ppmc]

$\because: \because \because$ PHILLIPS $\_$D2 REFERENCE
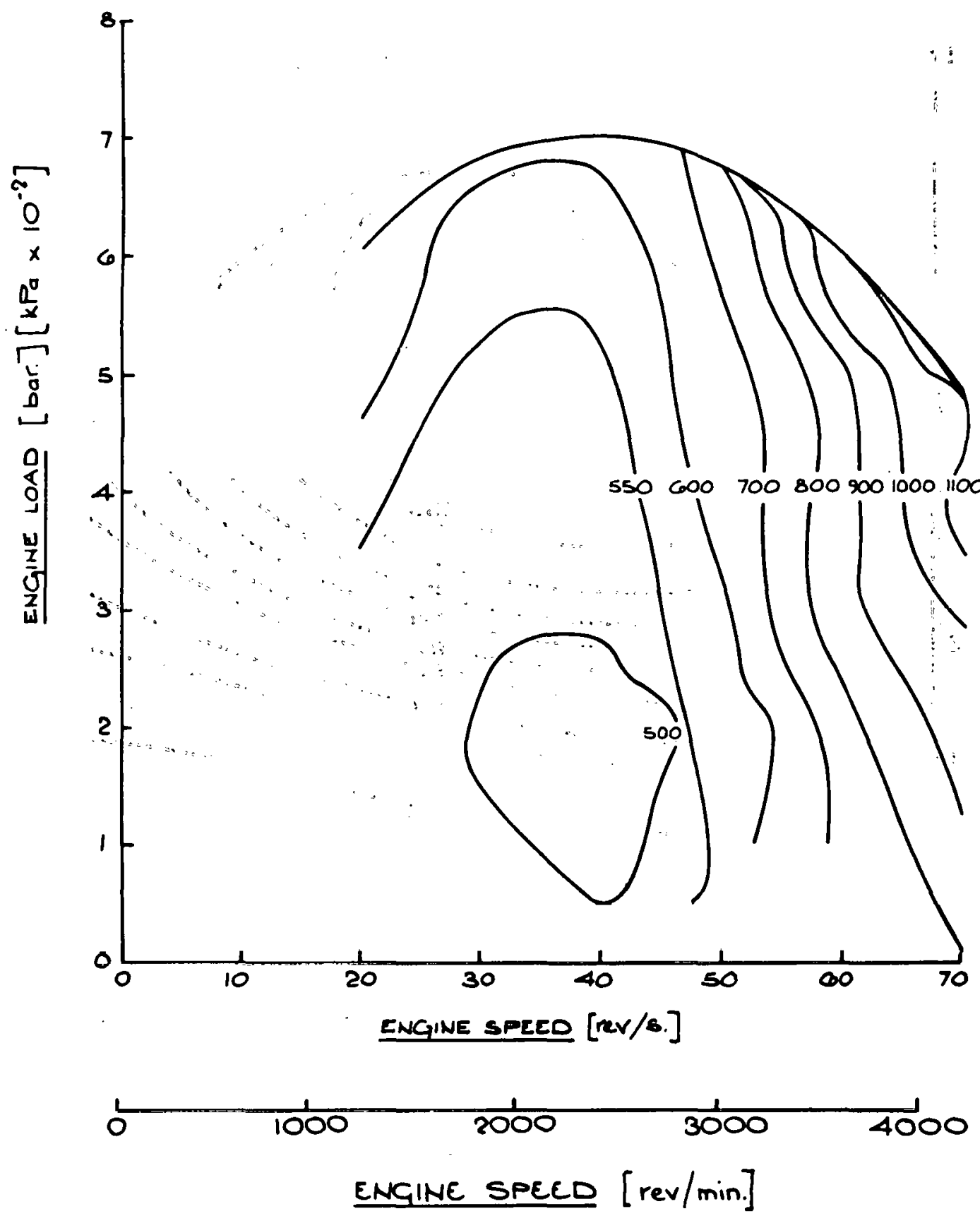


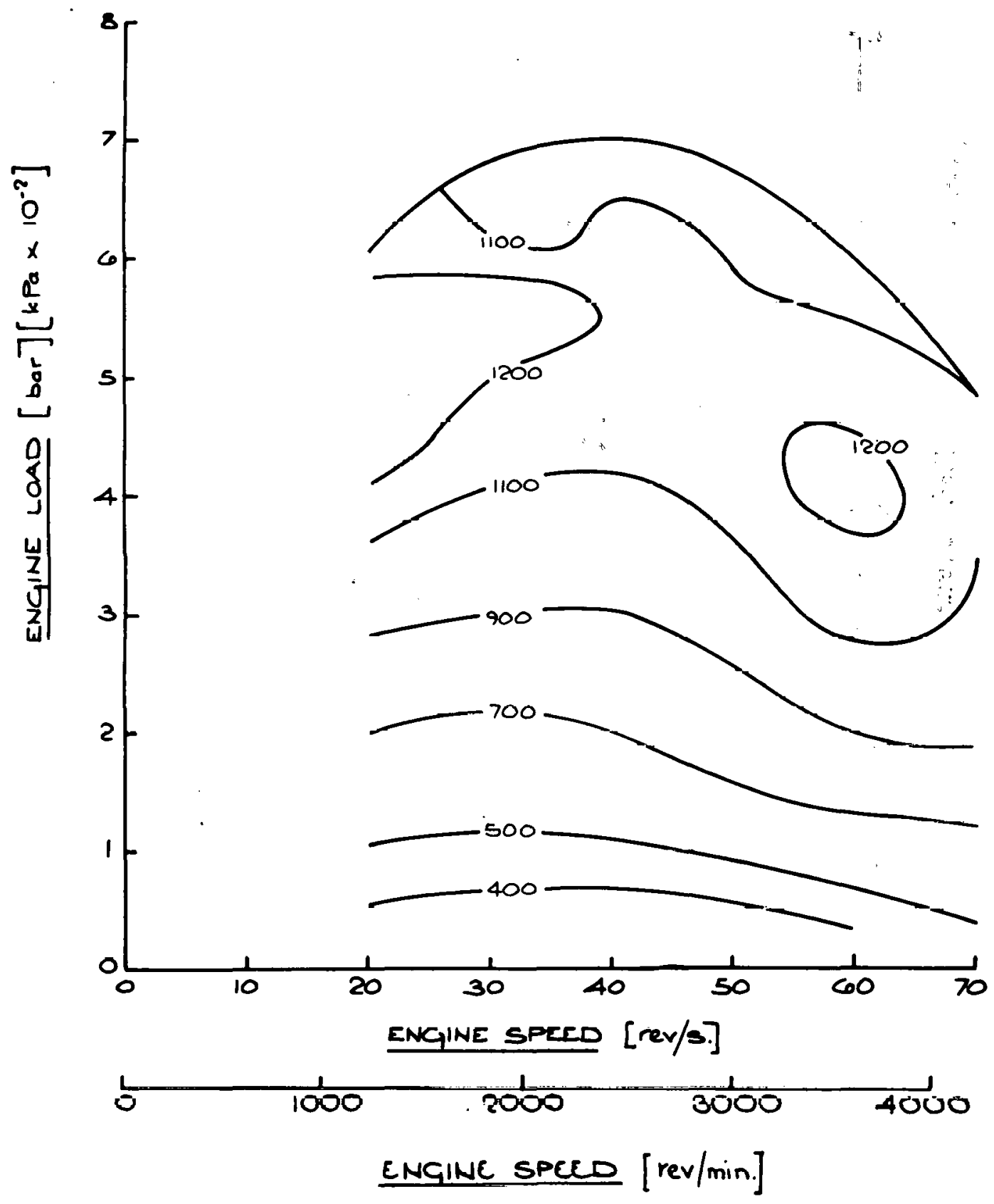


IAPPENDIX 4b-42.DI DIESEL [CONTOUR IMAP

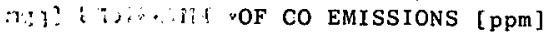

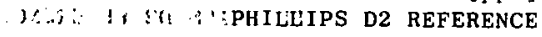

FUEU '

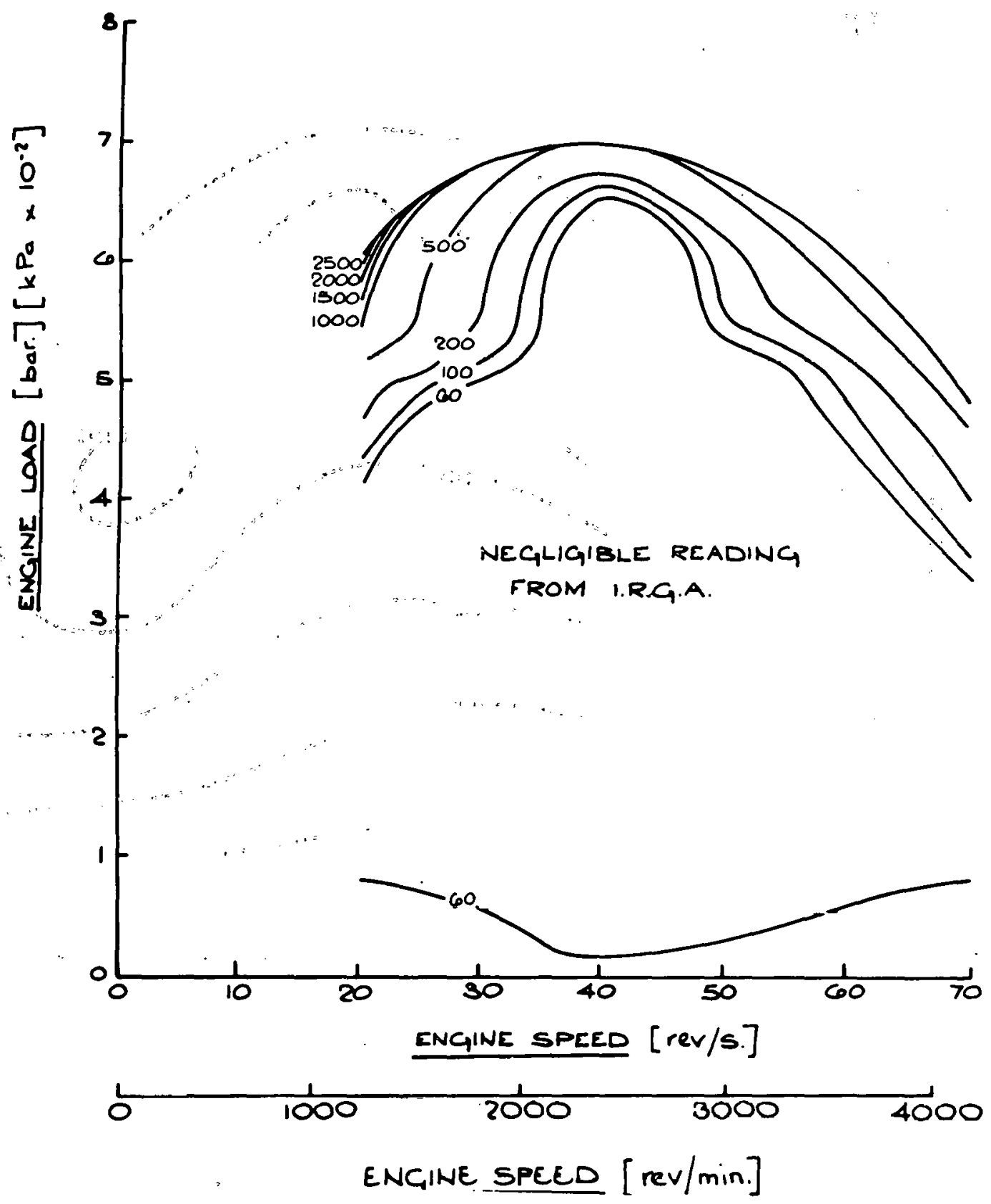




$$
\begin{aligned}
& \text { APPENDIX } 4 \mathrm{C}-1 \\
& \begin{array}{l}
\text { INFLUENCE OF ALTERNATIVE } \\
\text { FUELS }
\end{array} \\
& \text { at } 20 \mathrm{rev} / \mathrm{s}(1200 \mathrm{rev} / \mathrm{min})
\end{aligned}
$$

PHILLIPS D.2 REFERENKE FUEL $=1.0$

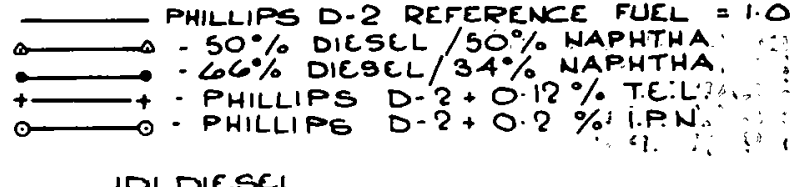

IDI DIESEL

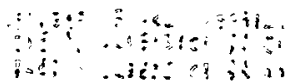

VARIAELE VOLATILITY FUELS

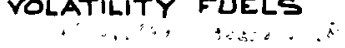
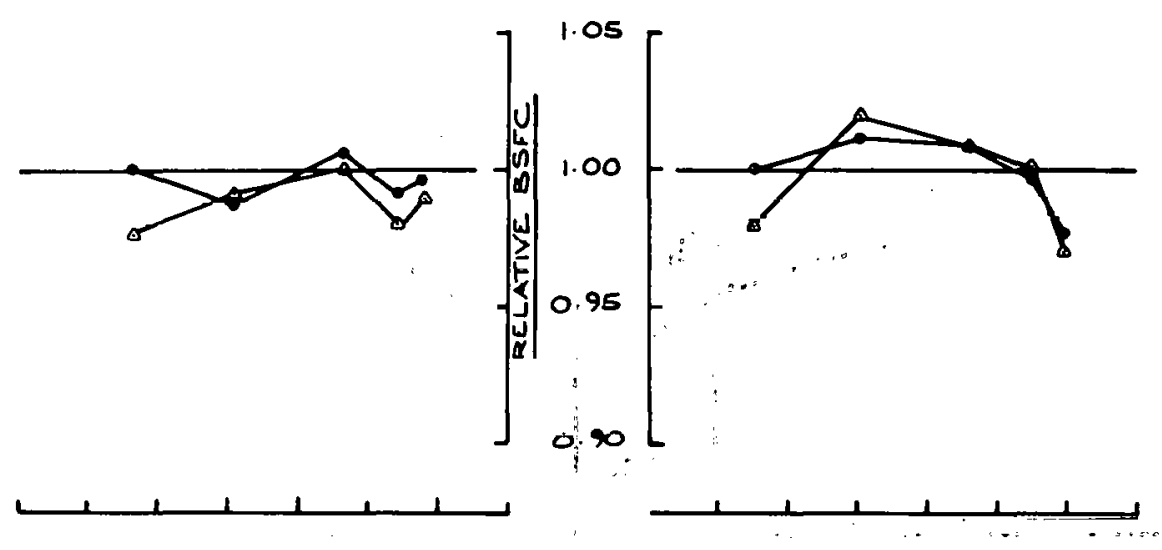

VARIABLE IGNITION QUALITY FUELS
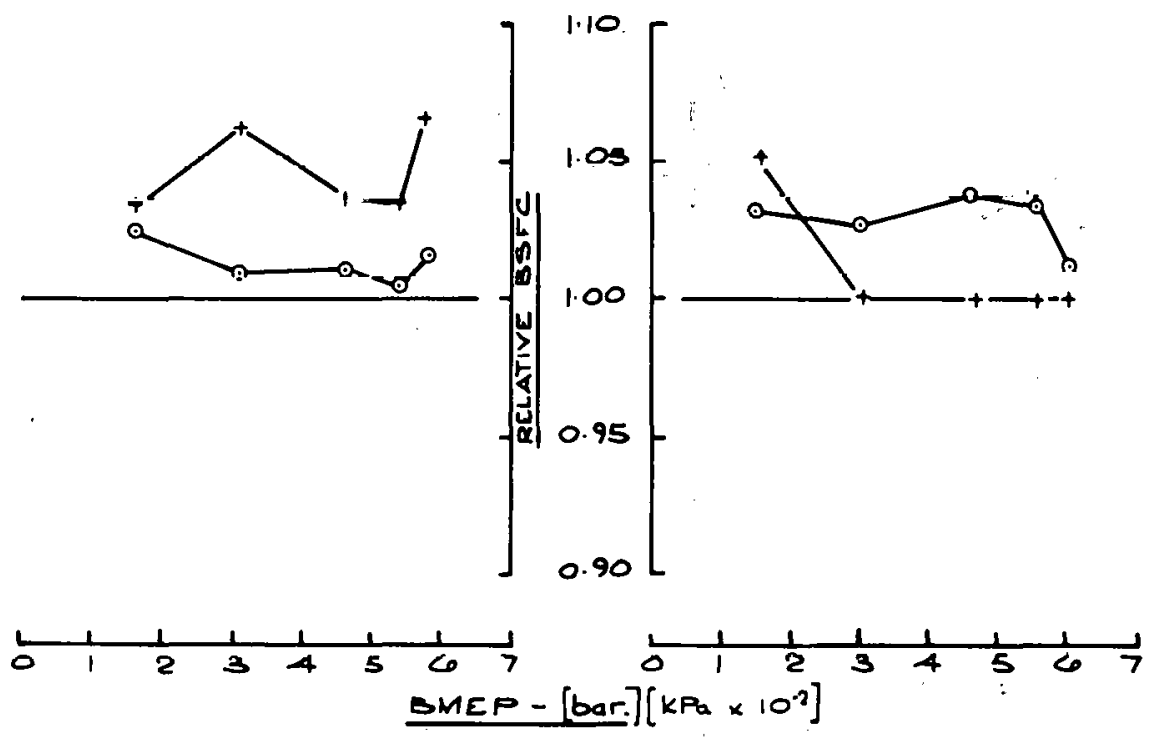


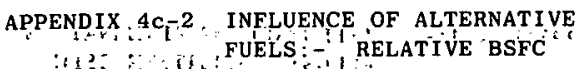

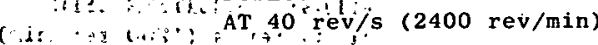

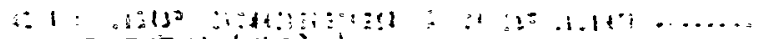

PHILLIPS D. 2 REFERENCE FUEL $=1: 0$

- $50 \%$ DIESEL $/ 50 \%$ NAPHTIHA

L6\% DIESEL/ $34 \%$ NAPHTHA

- PHILliPS $0.2+0.12 \%$ TEL

PHILLIPS D-?

IDI DIESEL

\section{DIESEL}

VARIABLE VOLATILITY Fuels
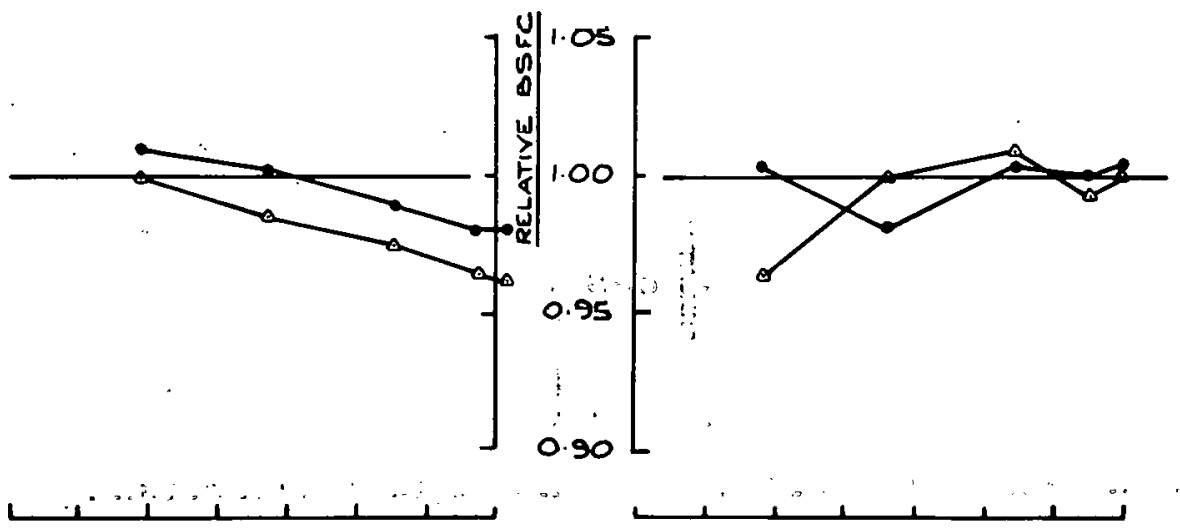

variable iGnitión qualitity fuels
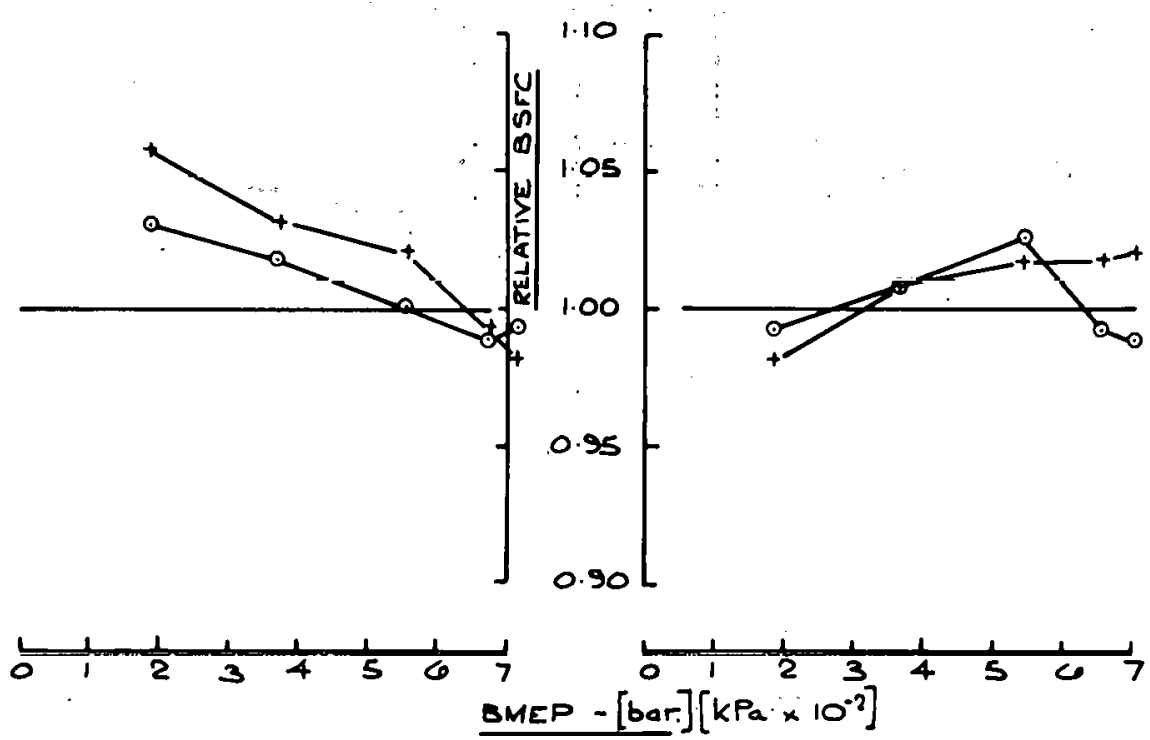


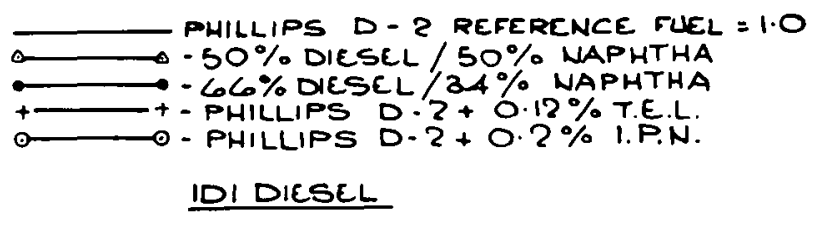

VARIABLE VOLATILITY FUELS
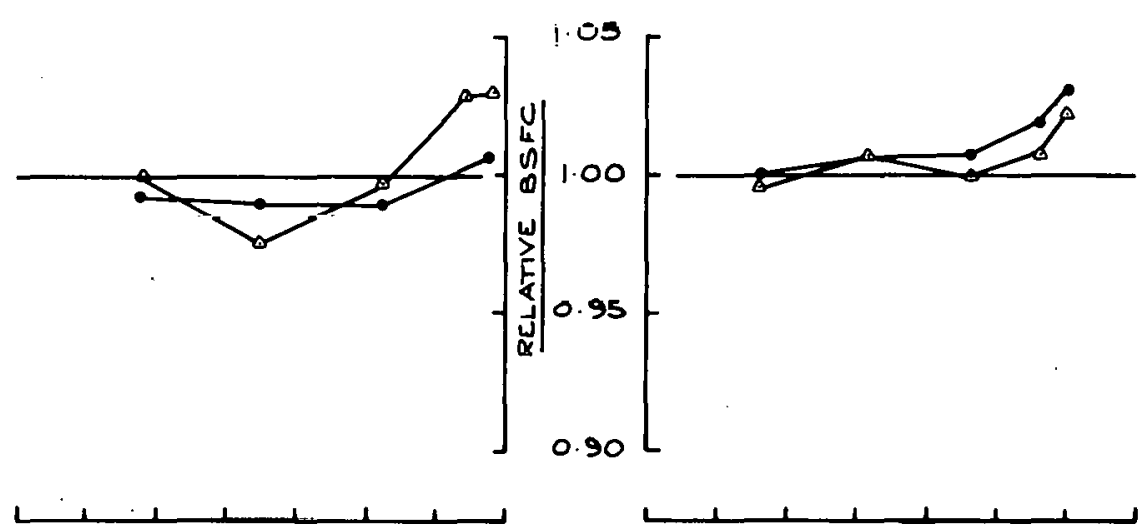

VARIABLE IGNITION QUALITY FUELS
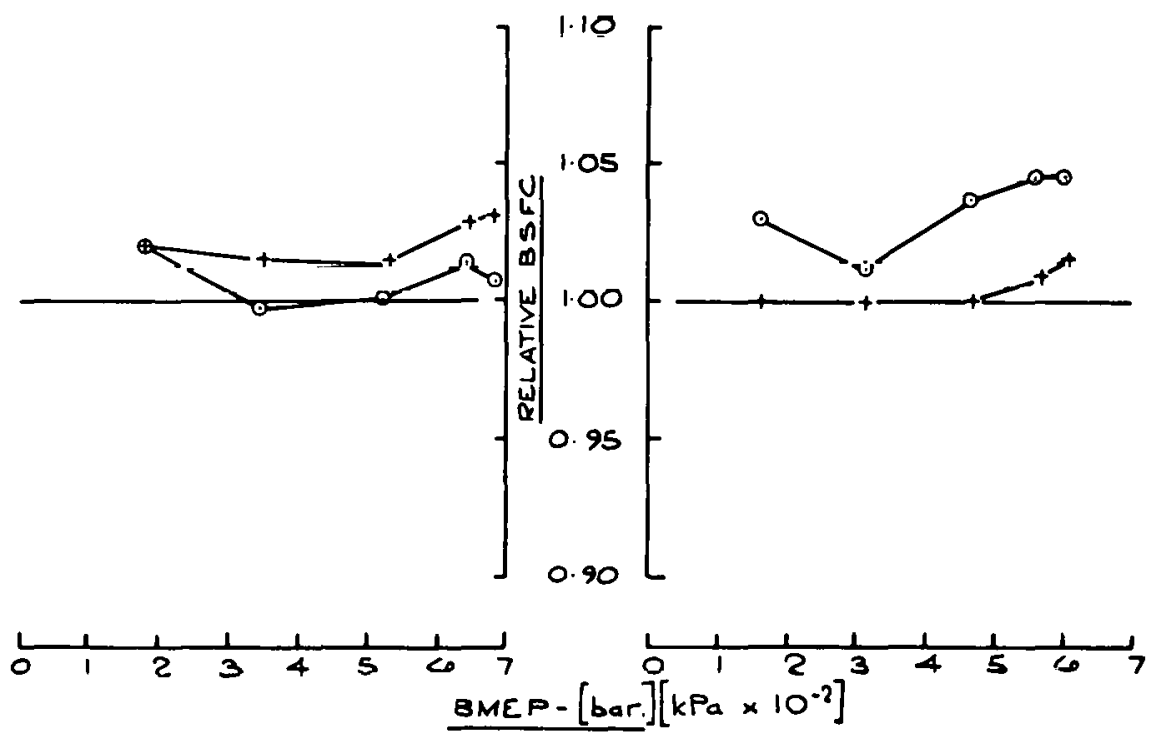


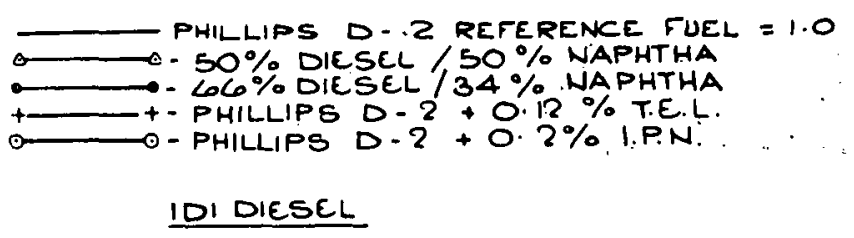

VARIABLE VOLATILITY FUELS
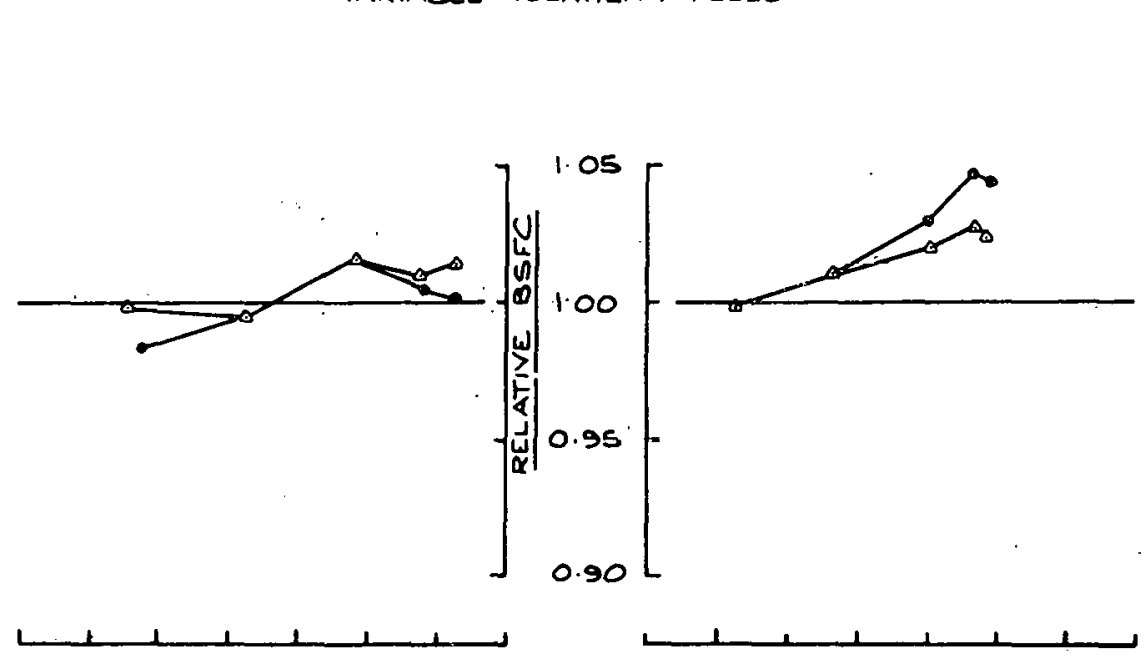

VARIABLE IGNITION QUALITY FUELS

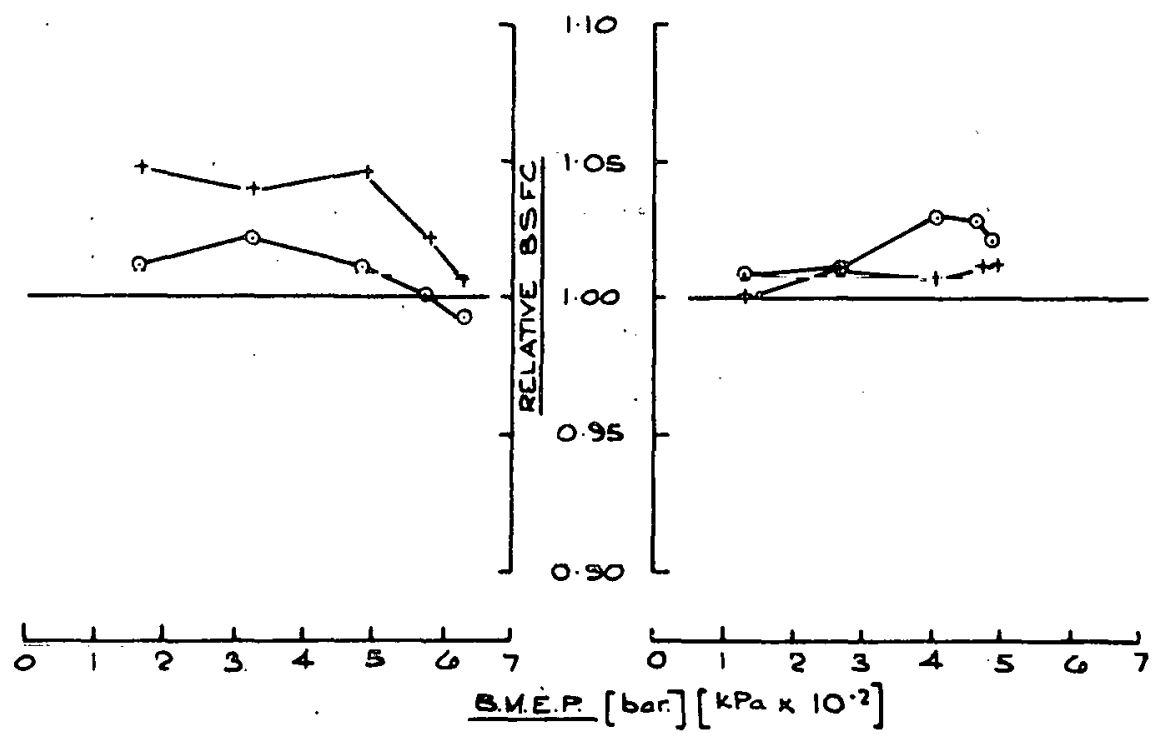


APPENDIX 4d-1 INFLUENCE OF ALTERNATIVE

FUELS:- RELATIVE BSEC AT

$20 \mathrm{rev} / \mathrm{s}$ ( $1200 \mathrm{rev} / \mathrm{min})$

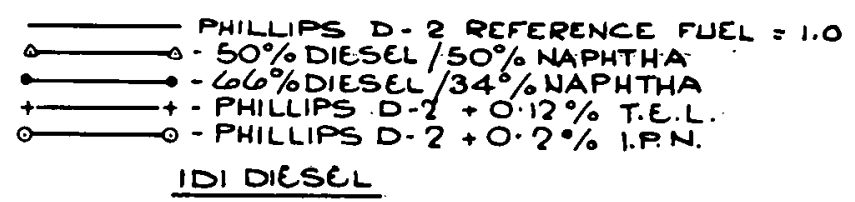

IDI DIESEL

DIDIESEL

YARIABLE YOLATILITY FUELS
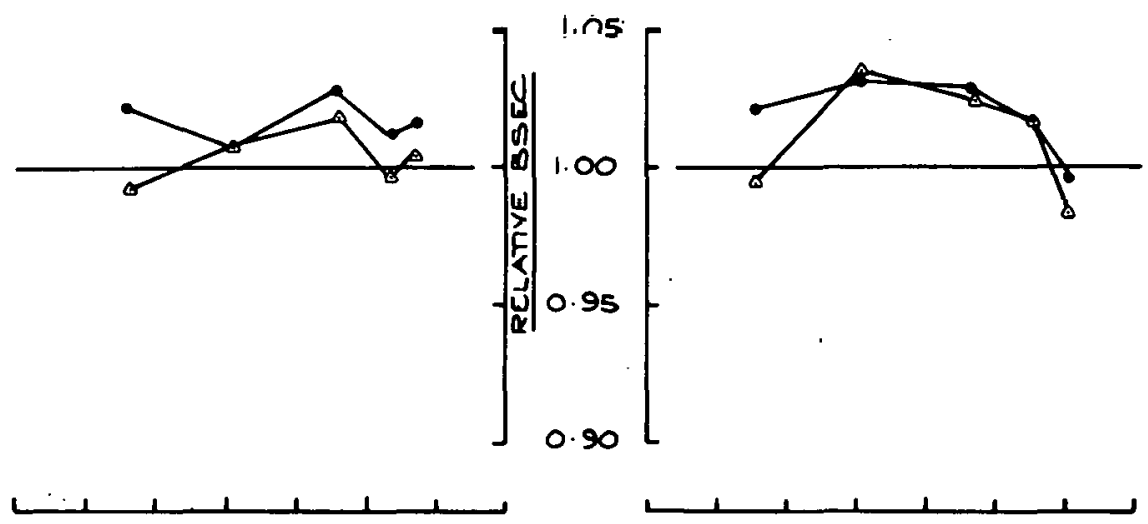

VARIABLE IGNITION QUALITY FUELS
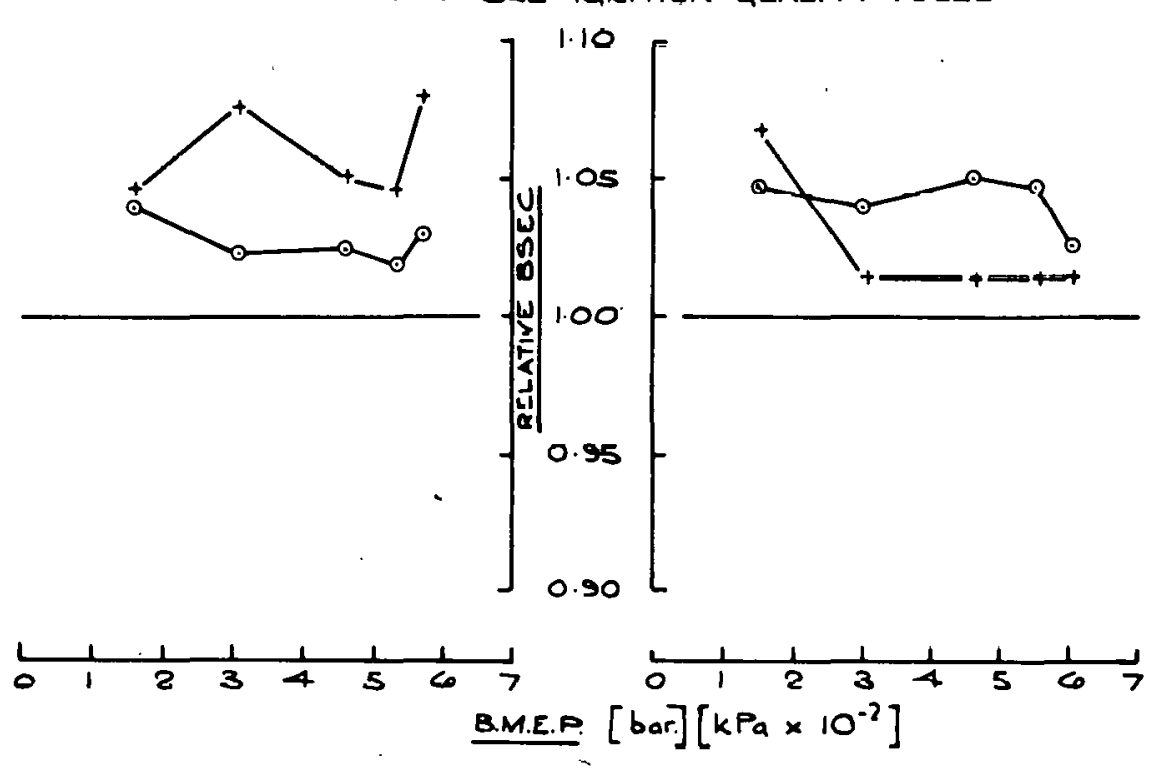
APPENDIX 4d-2 INFLUENCE OF ALTERNATIVE

FUELS:- RELATIVE BSEC

AT $40 \mathrm{rev} / \mathrm{s}(2400 \mathrm{rev} / \mathrm{min})$

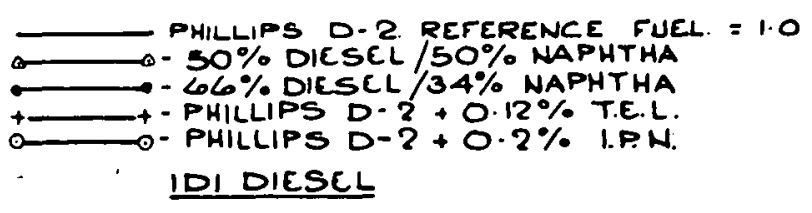

DI DIESEL

YARIABLE VOLATILITY FUELS
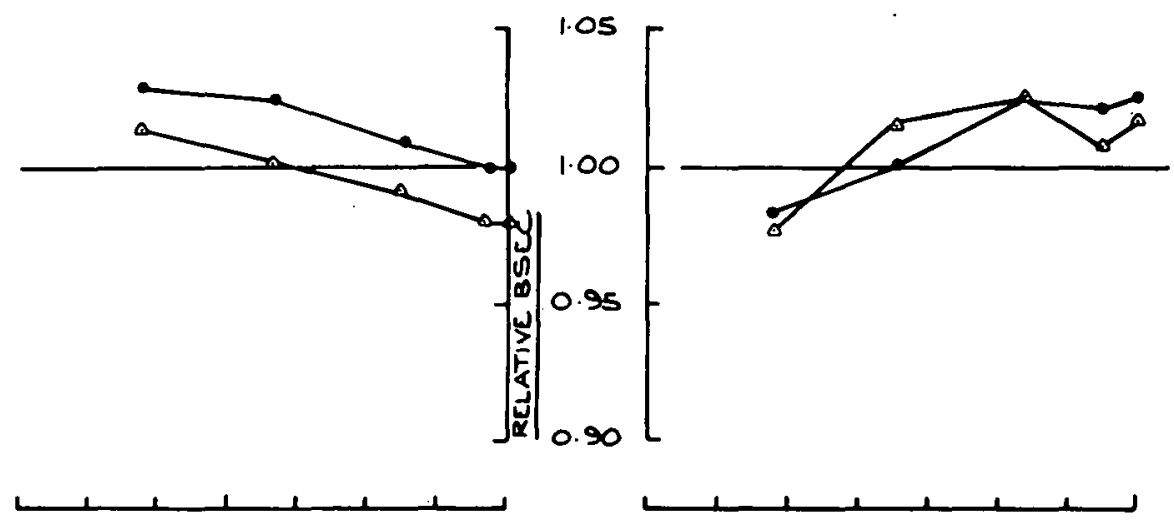

variable ignition quality fuels
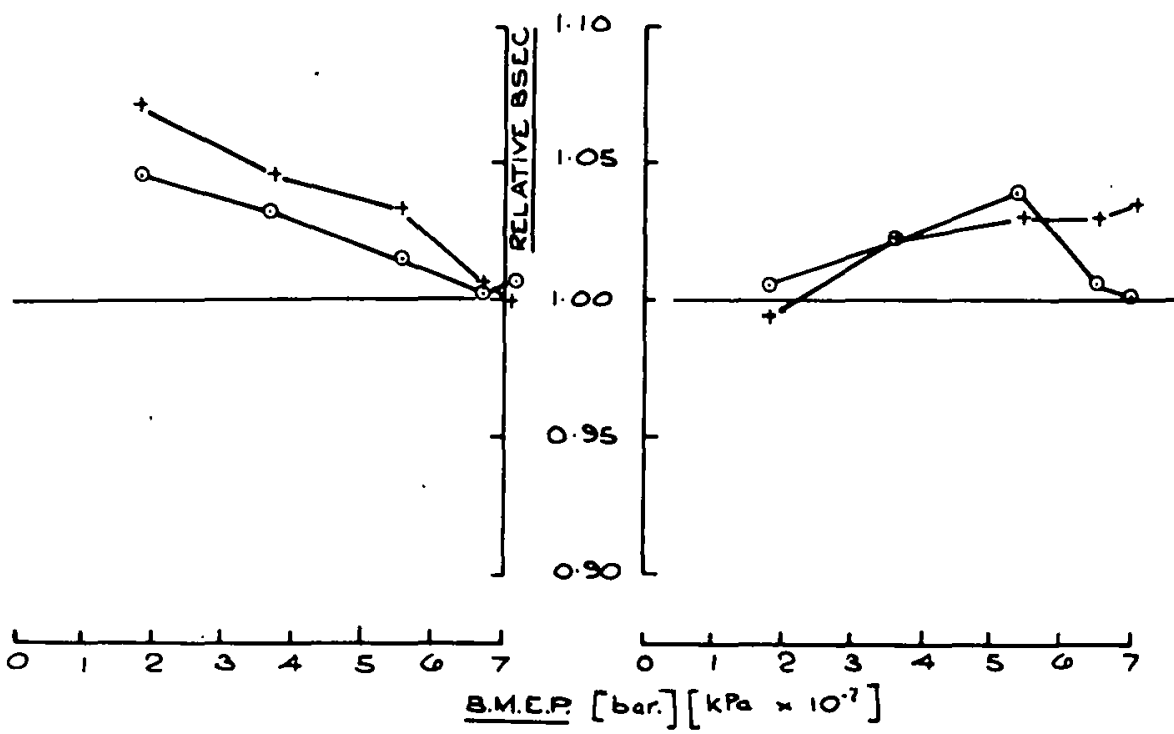

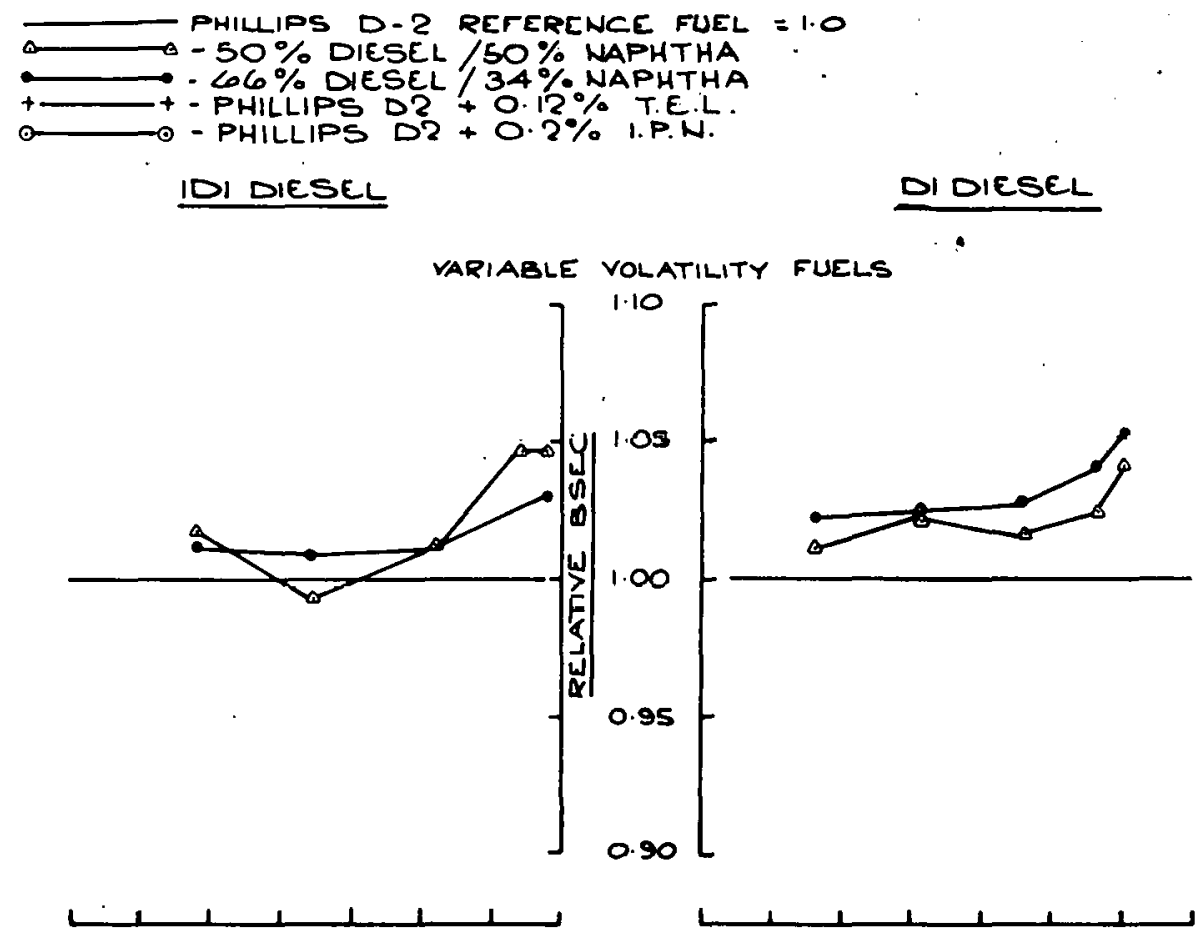

VARIABLE IGNITION QUALITY FuELS
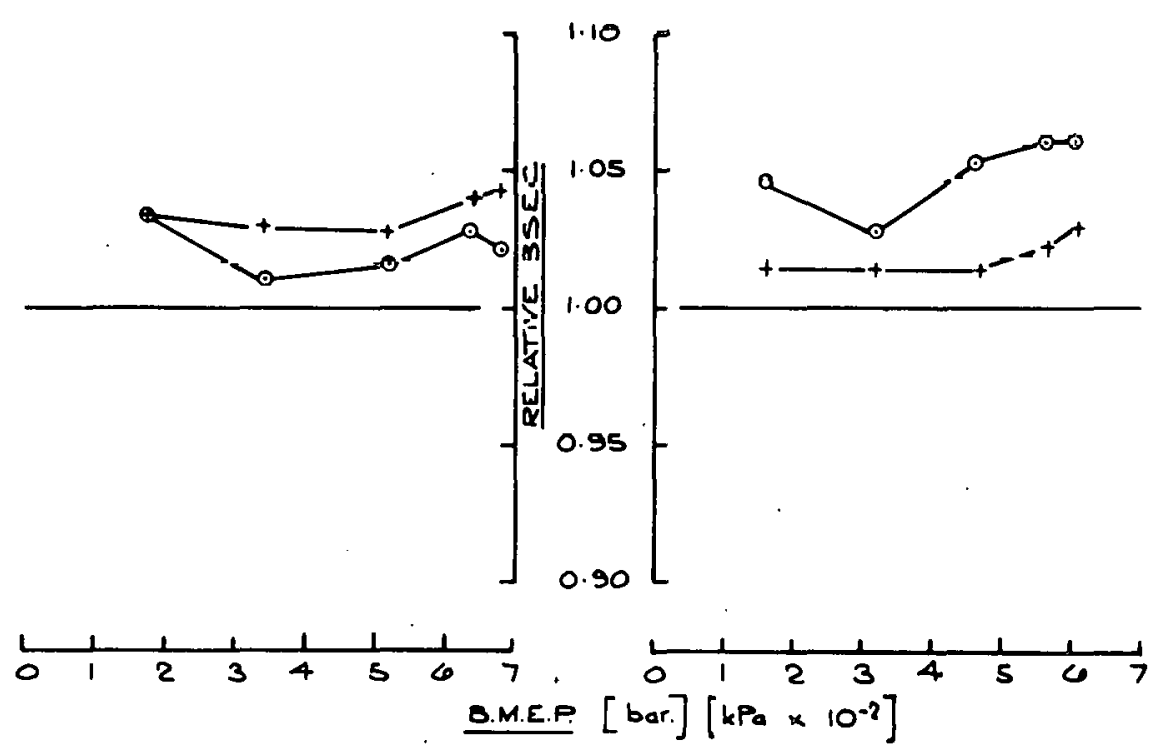
APPENDIX 4d-4 INFLUENCE OF ALTERNATIVE

FUELS :- RELATIVE BSEC

AT $70 \mathrm{rev} / \mathrm{s}(4200 \mathrm{rev} / \mathrm{min})$

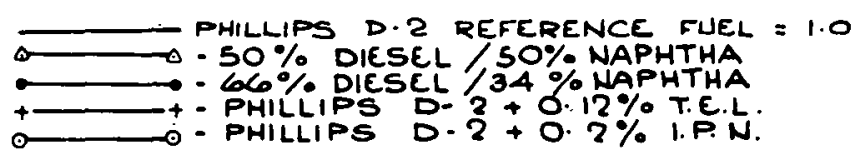

IDI DIESEL

이 DIESE
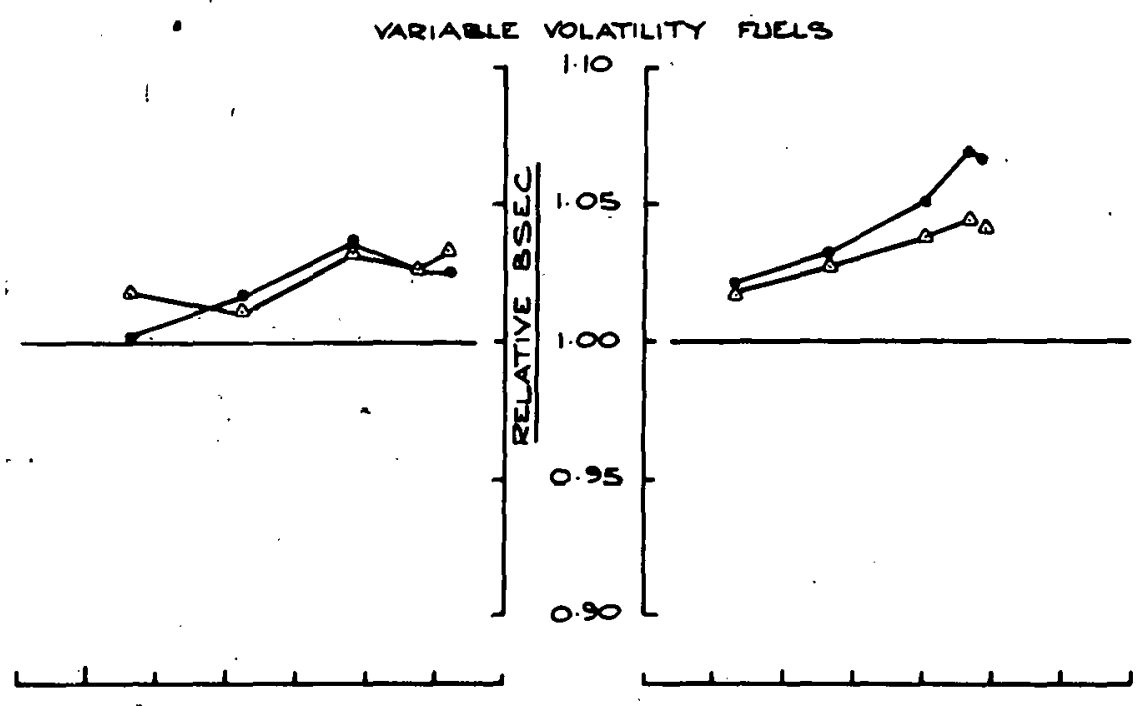

VARIABLE IGNITION QUALITY FUELS

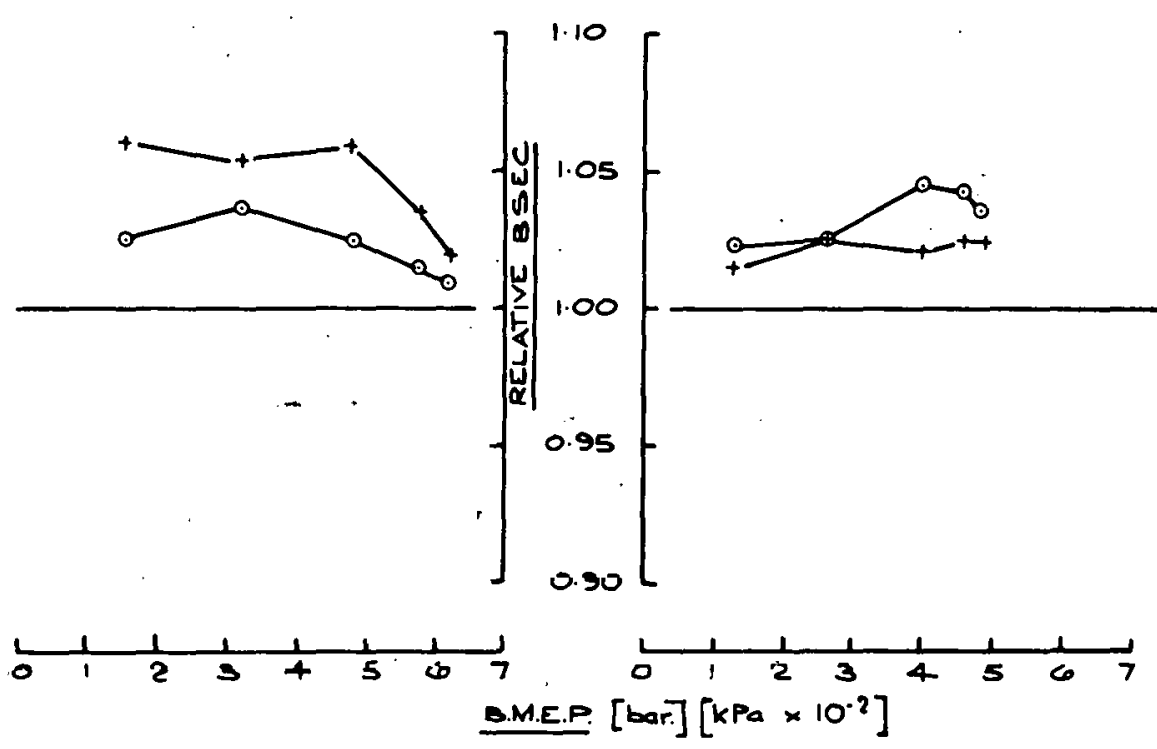




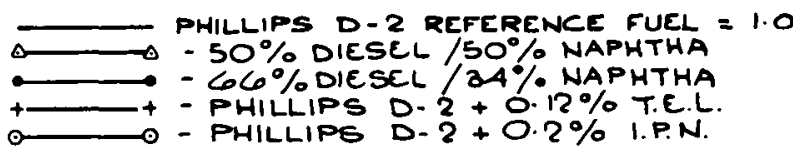

IDI DIESEL

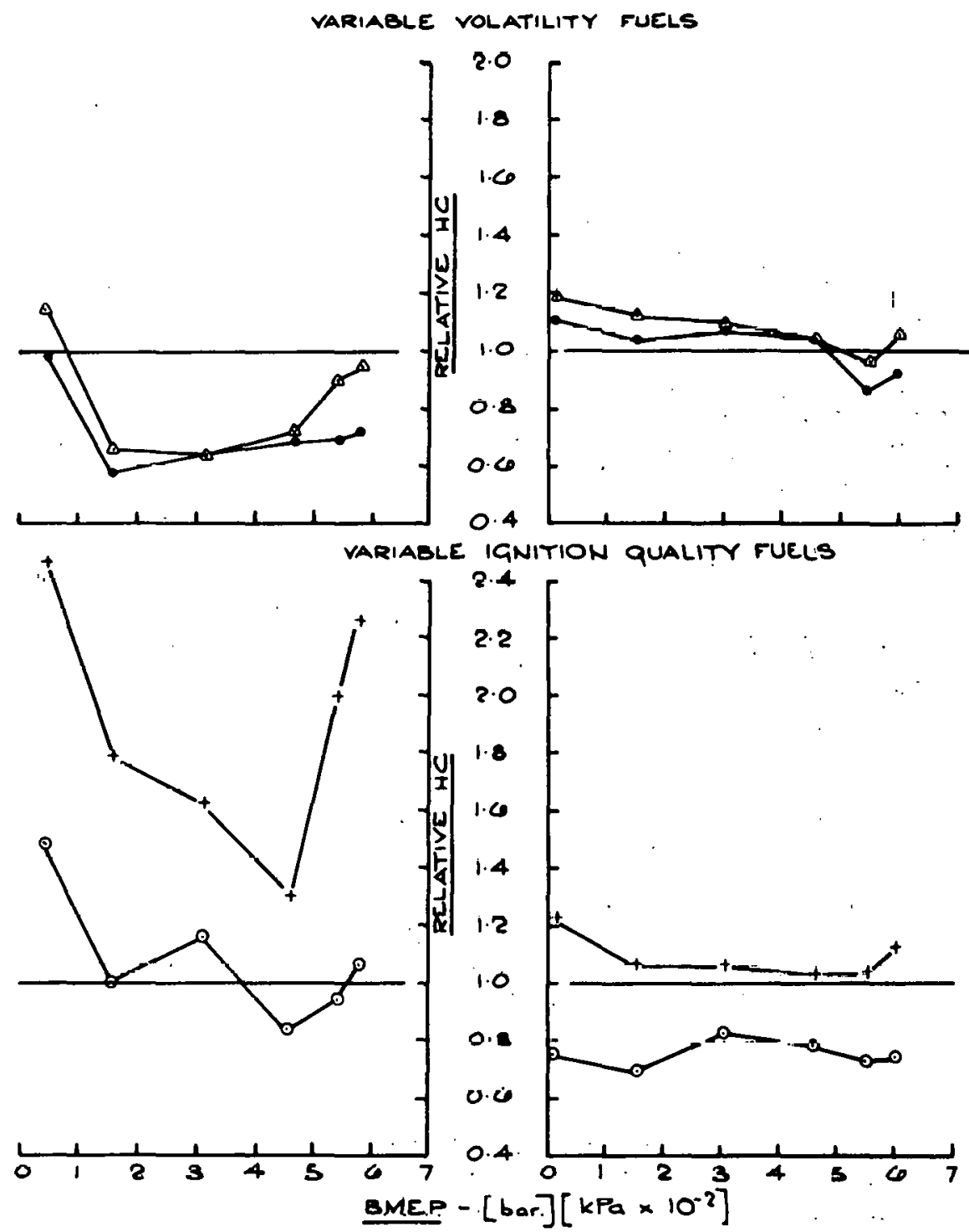


APPENDIX 4e-2 INFLUENCE OF ALTERNATIVE

FUELS:- RELATIVE HC

EMISSIONS AT $40 \mathrm{rev} / \mathrm{s}$

( $2400 \mathrm{rev} / \mathrm{min})$

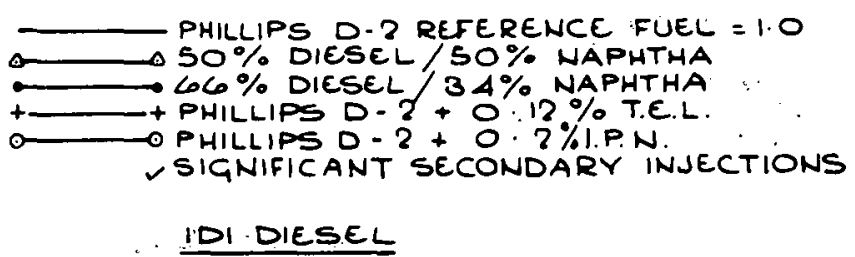

DI DIESEL

VARIABLE, VOLATILITY, FUELS.

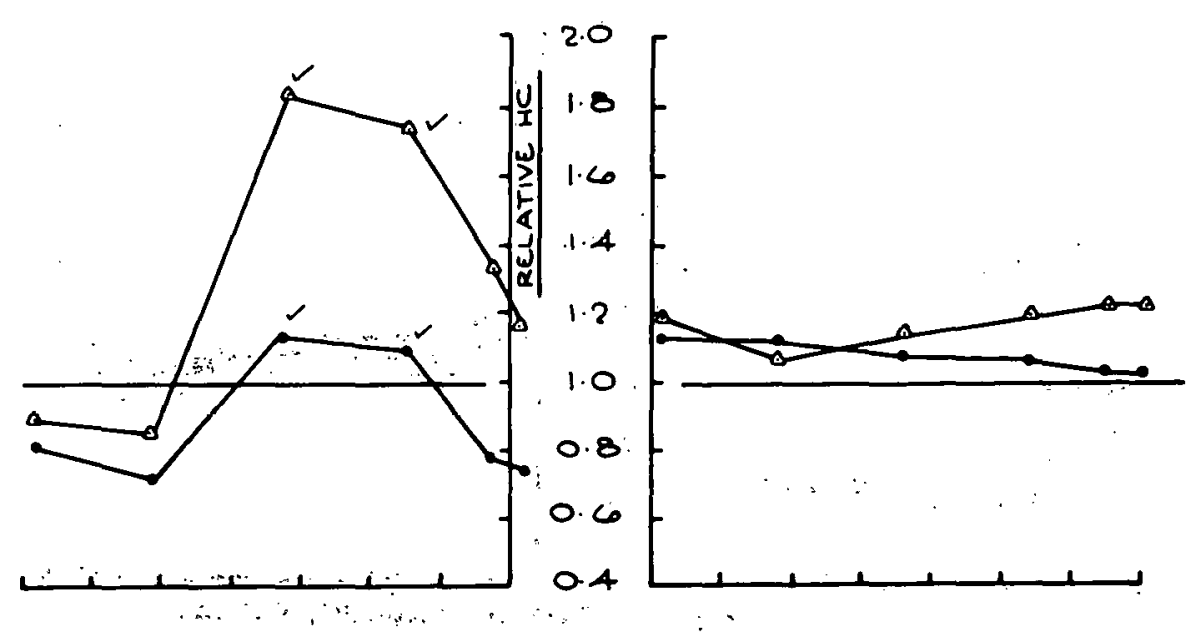

VARIABLE IGNITION QUALITY FUELS

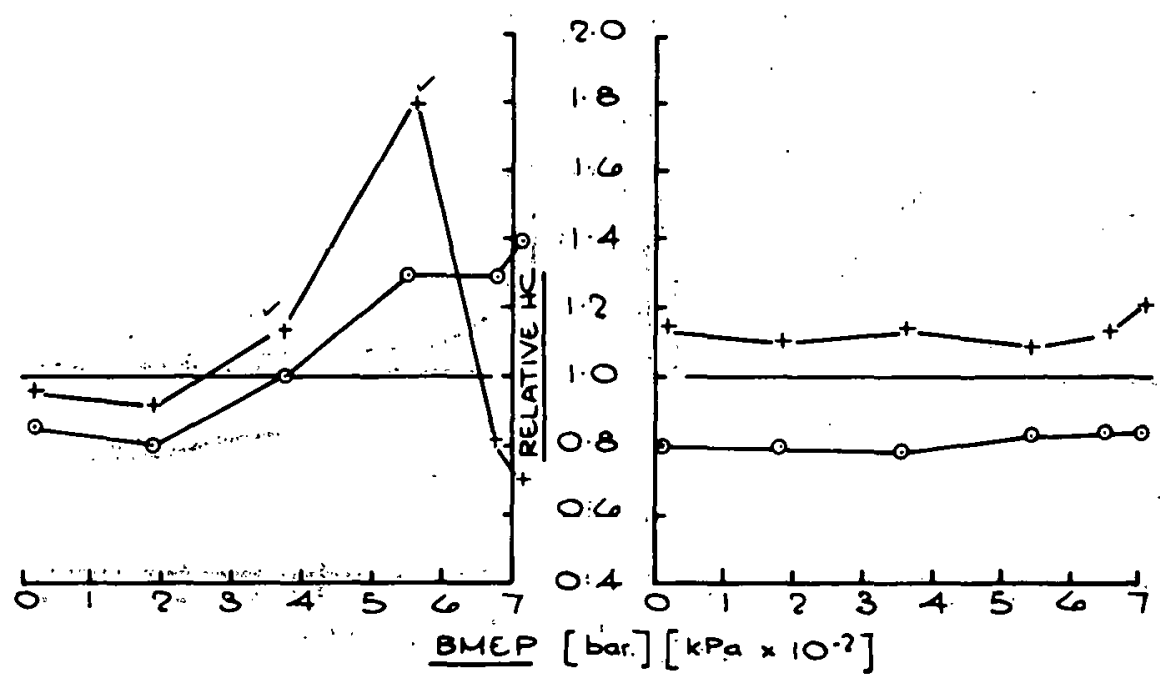


APPENDIX 4e-3 INFLUENCE OF ALTERNATIVE

FUELS:- RELATIVE HC

EMISSIONS AT $60 \mathrm{reV} / \mathrm{s}$

(3600 rev/min)
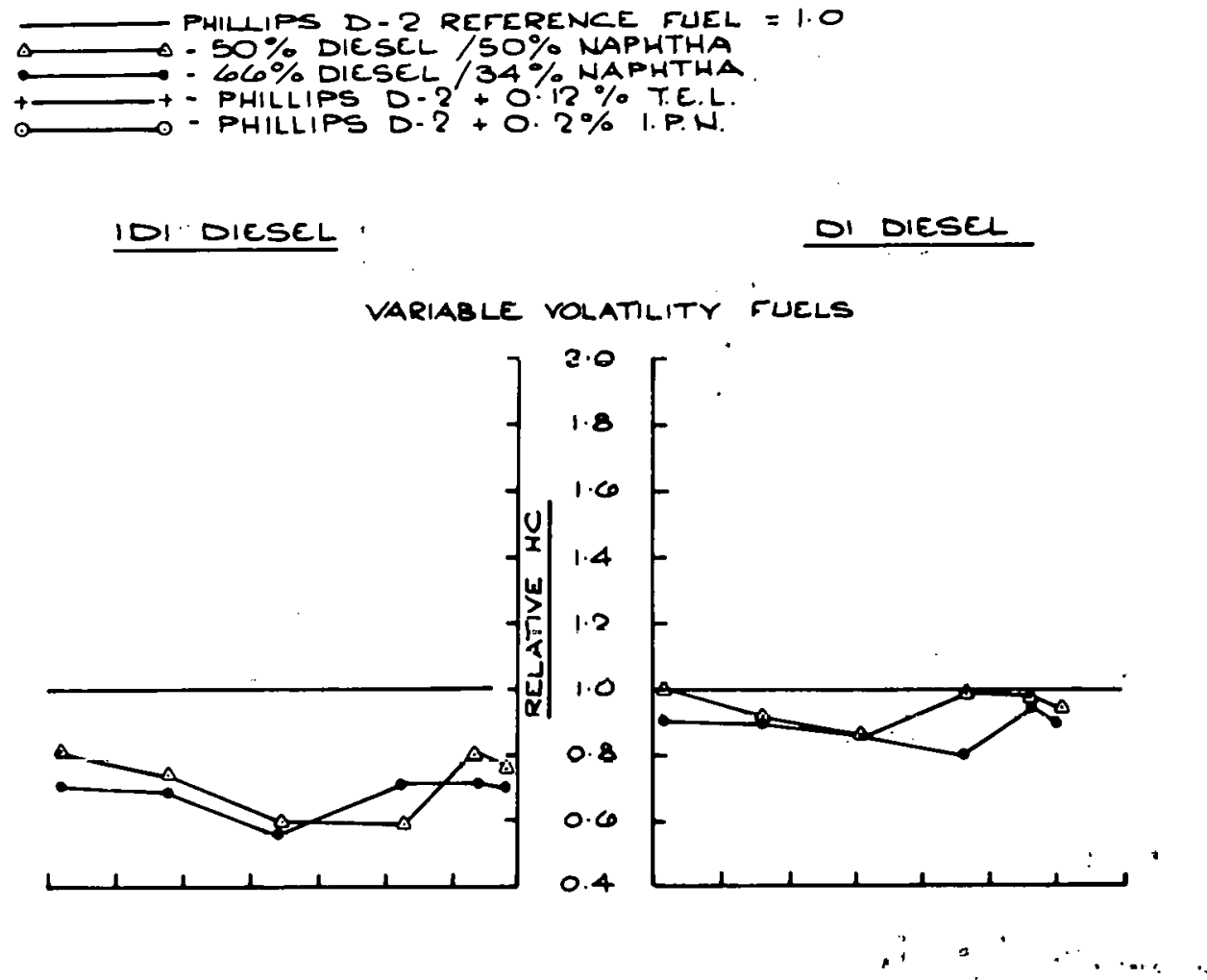

VARIABLE IGNITION quALITY FUELS

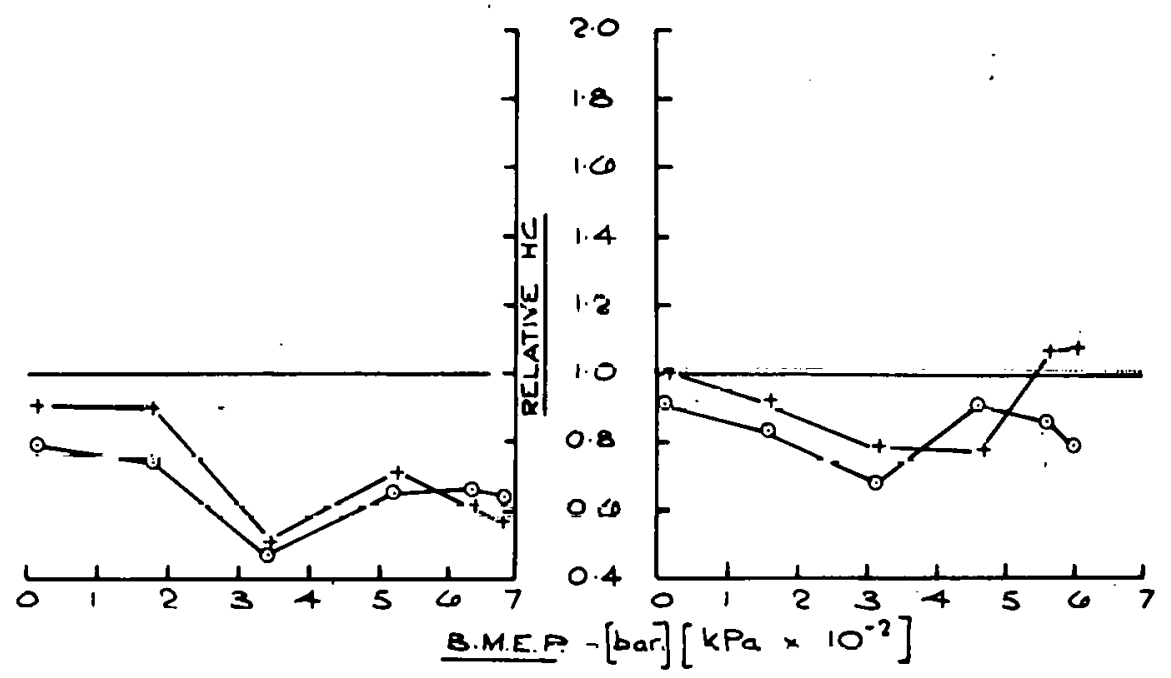


APPENDIX $4 e-4$ INFLUENCE OF ALTERNATIVE

FUELS:- RELATIVE HC

EMISSIONS AT $70 \mathrm{rev} / \mathrm{s}$

(4200 $\mathrm{rev} / \mathrm{min}$ )

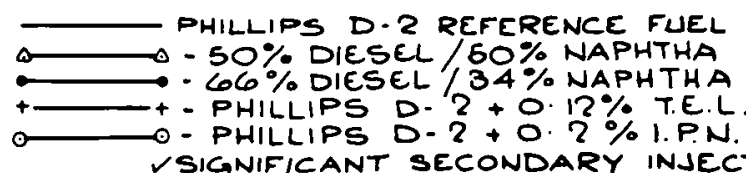

$\checkmark$ SIGNIFICANT SECONDARY INJECTIONS

IDI DIESEL

DI DIESEL

VARIABLE VOLATILITY FUELS
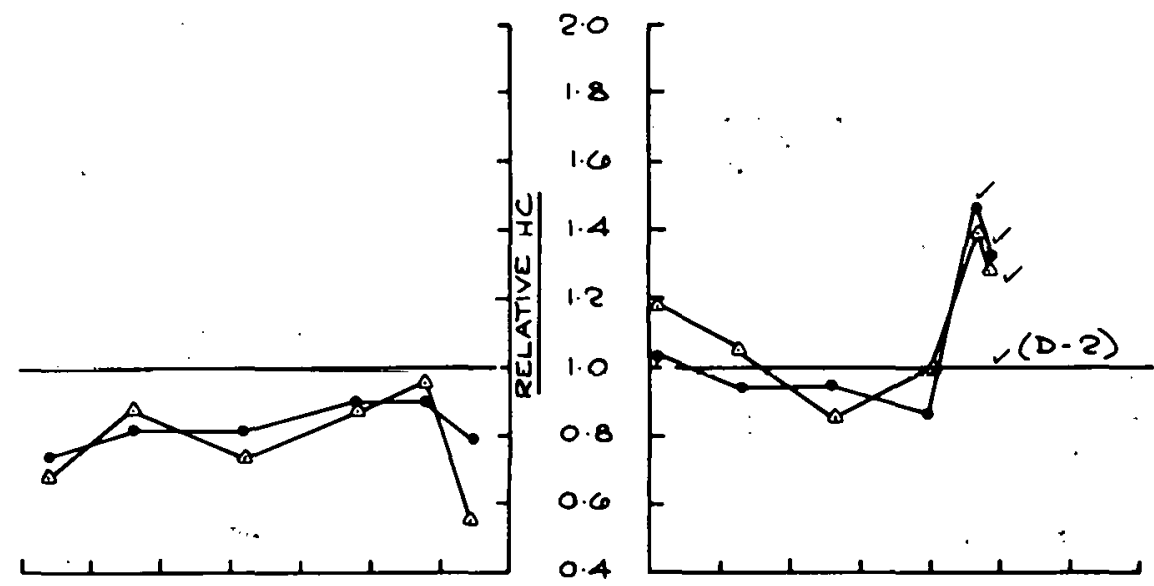

VARIABLE IGNITION QUALITY FUELS

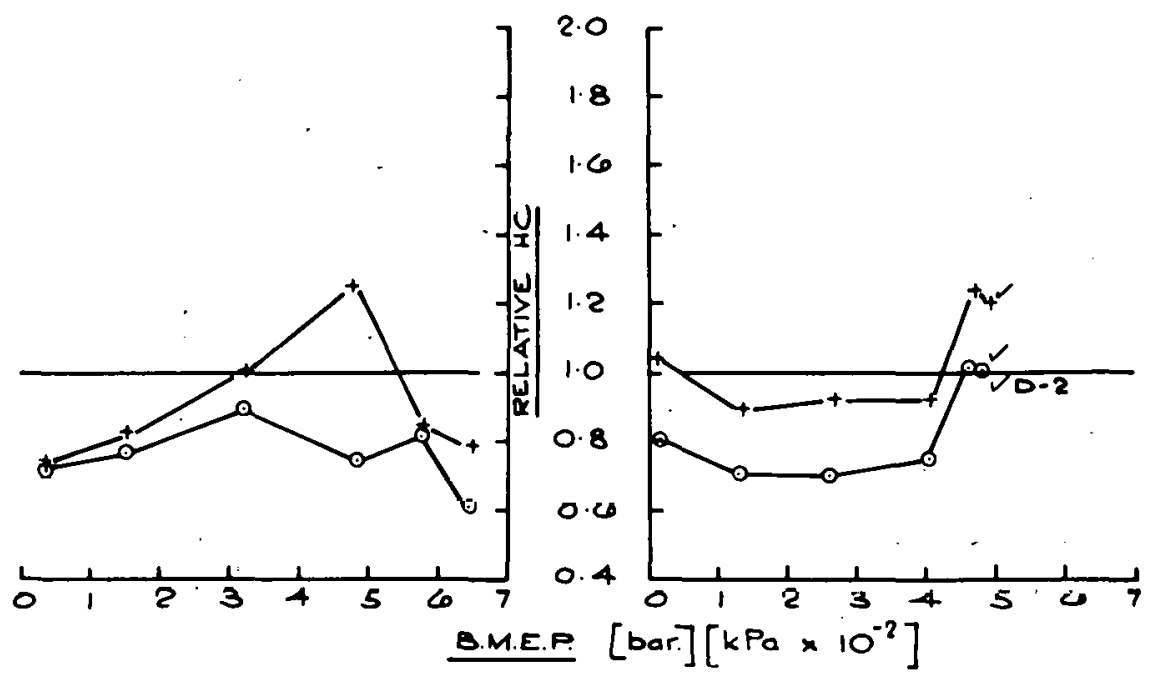


FUELS :- RELATIVE NOX

EMISSIONS AT 20 .rev/s

(1200 rev/min)

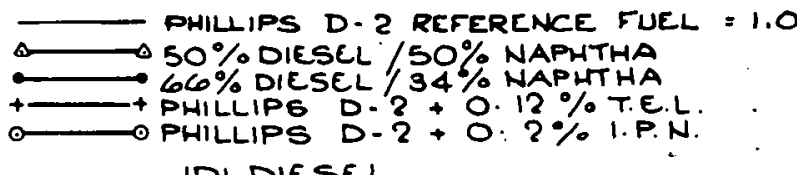

IDI DIESEL

VARIABLE VOLATILITY FUELS

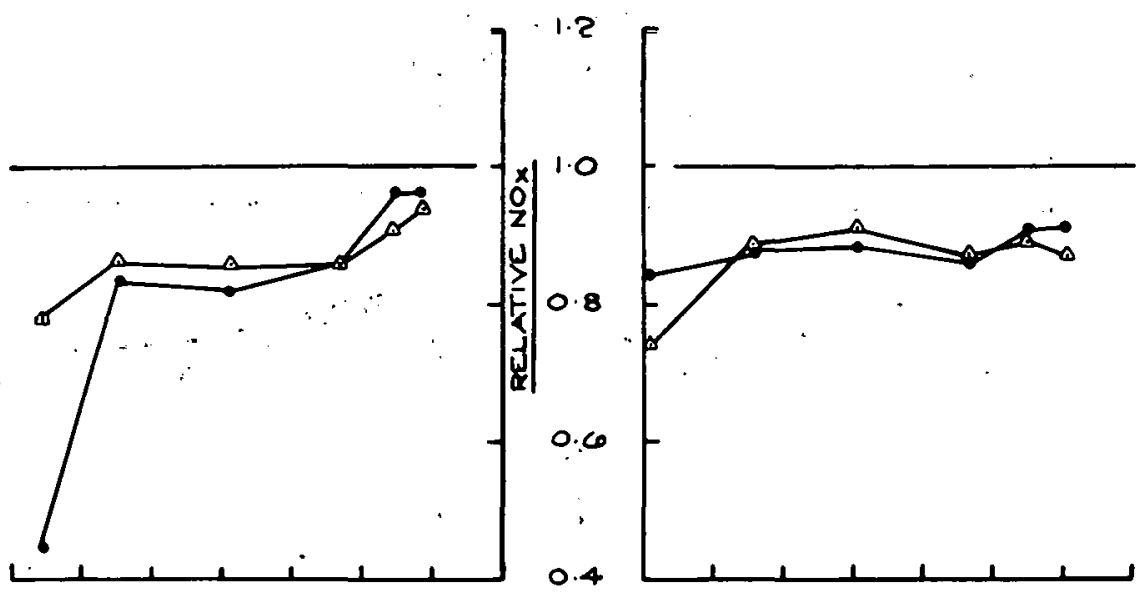

VARIABLE IGNITION QUALITY FUELS

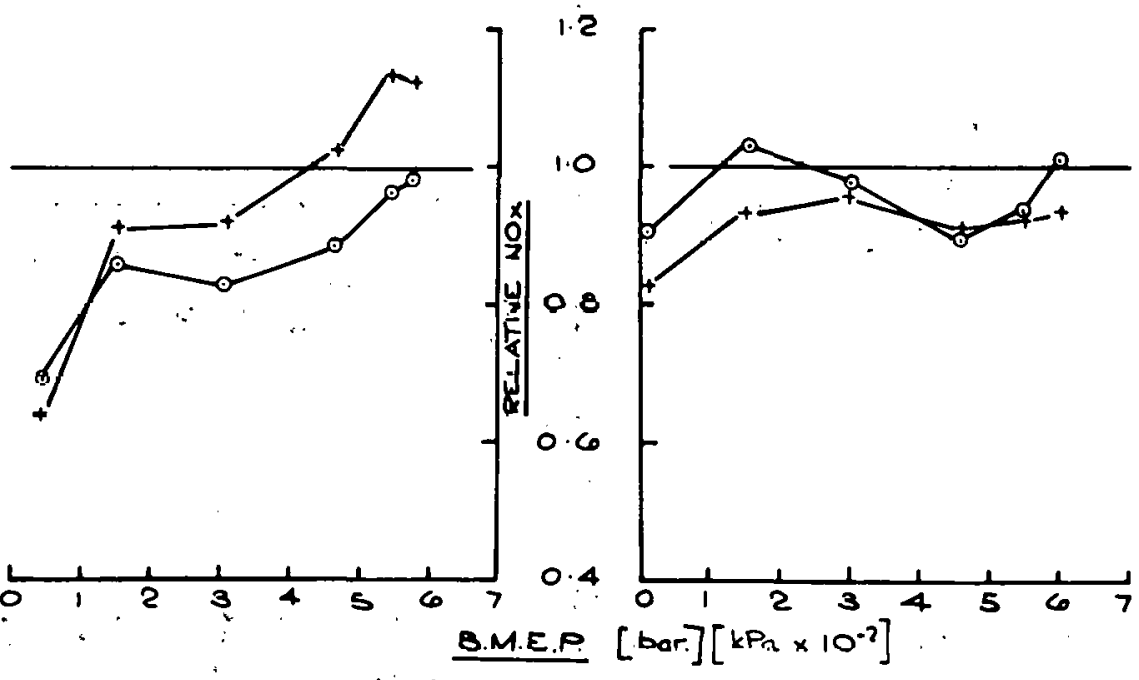




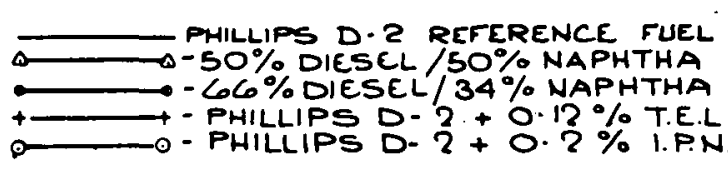

IDI DIESEL

DI DIESEL

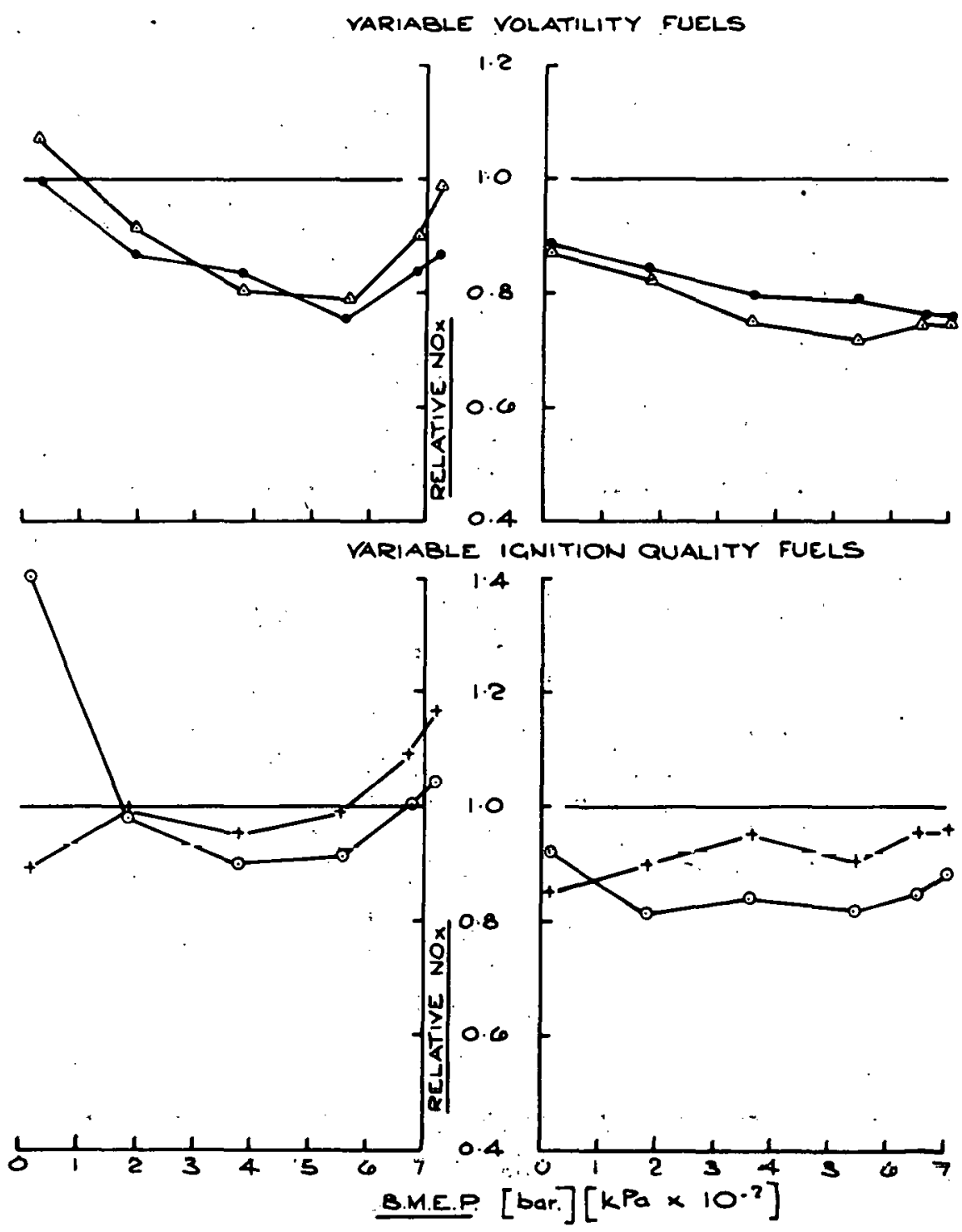



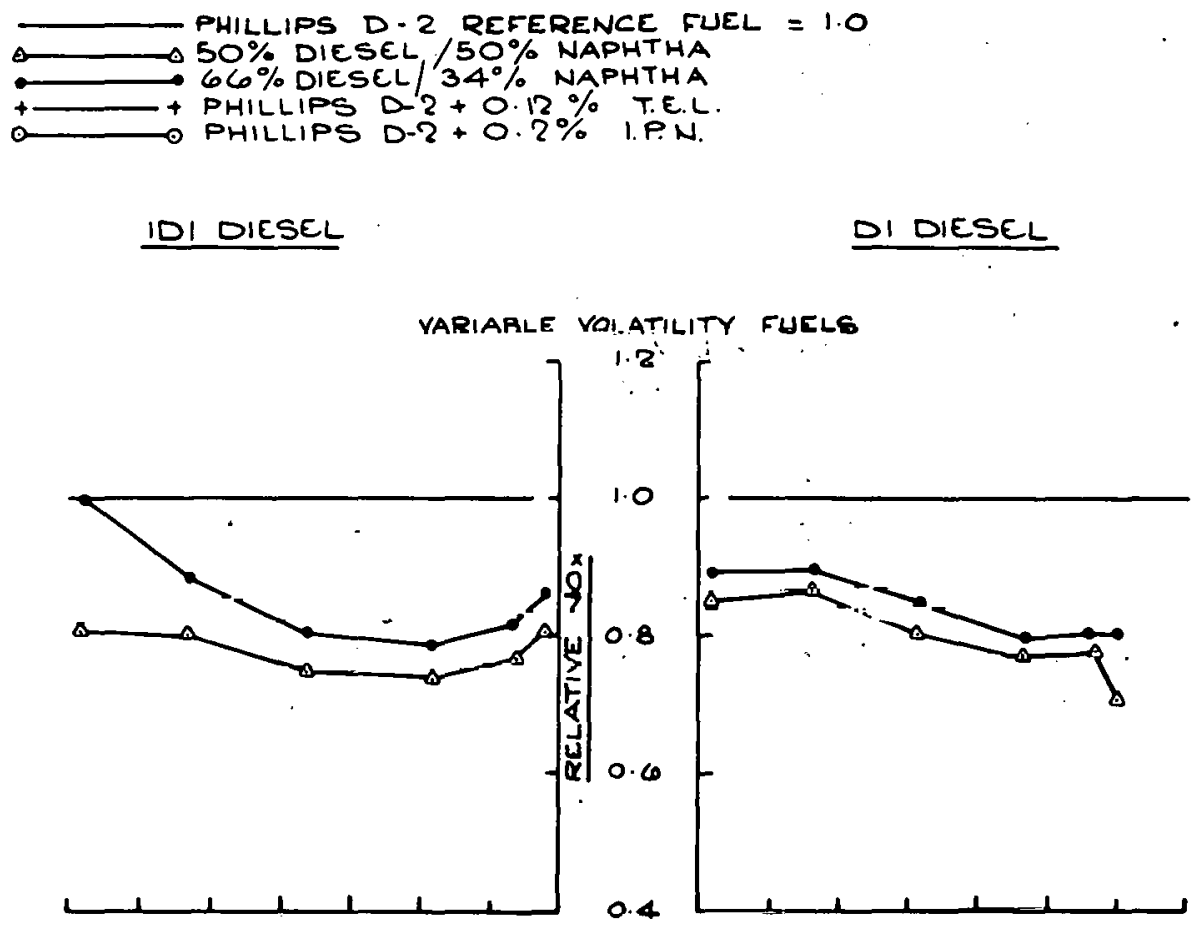

VARIABLE ICNITION QUALITY FUF.LS

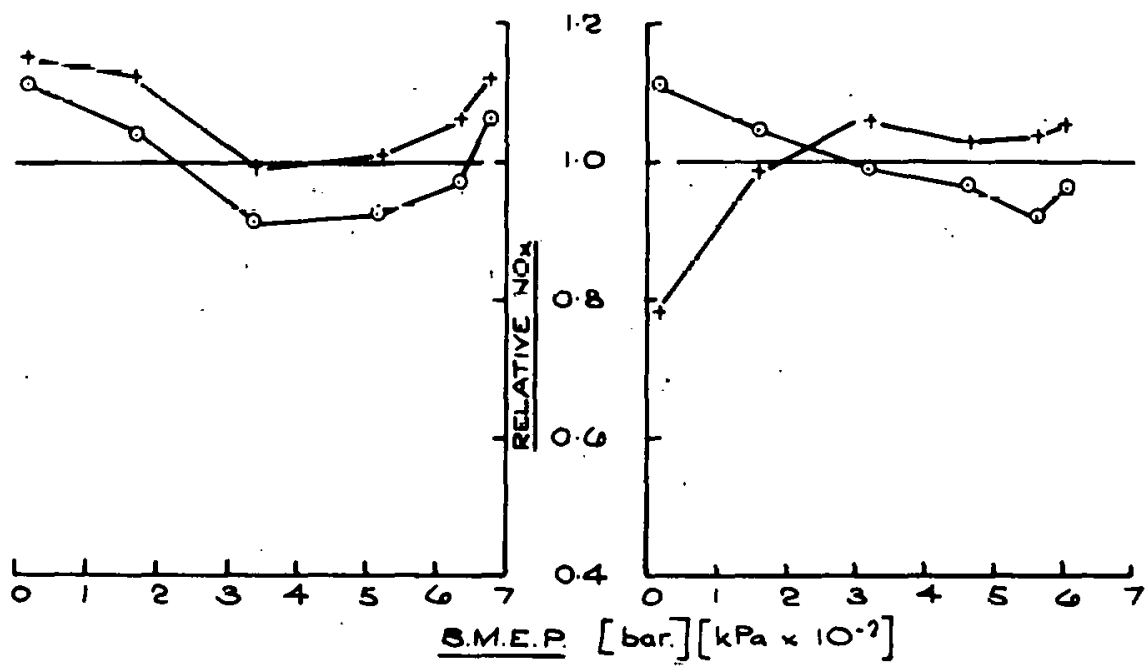



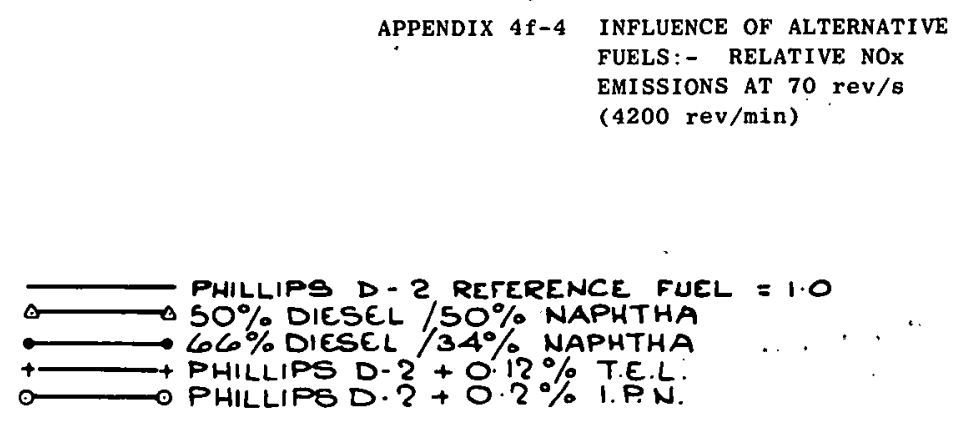

IDI DIESEL

DI DIESEL
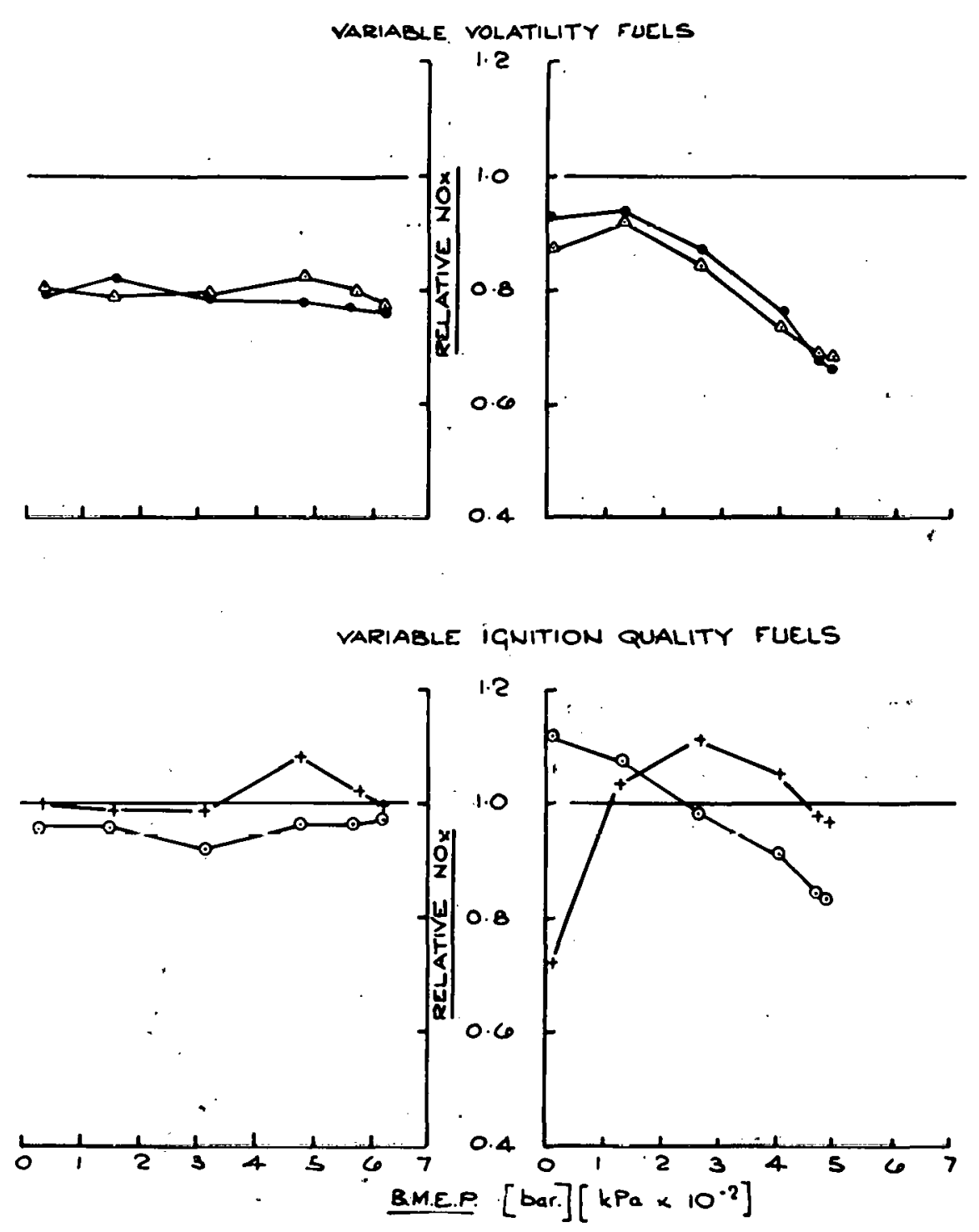
APPENDIX $4 \dot{g}-1$ INFLUENCE OF ALTERNATIVE

FUELS:- RELATIVE CO

EMISSIONS AT $20 \mathrm{rev} / \mathrm{s}$

(1200 rev/min)

PHILLIPS D.2 REFERENCE FUEL $=1.0$

- 50\% DIESEL / $50 \%$ NAPHTHA

- $66 \%$ DIESEL $/ 34 \%$ NAPHTHA

- PHILlIPS D.2+0.12\% T.E.L.

- PHILLIPS $0.2+0.2 \% .1 . P . N$

VAMRIABLE VULATILITY FLELS
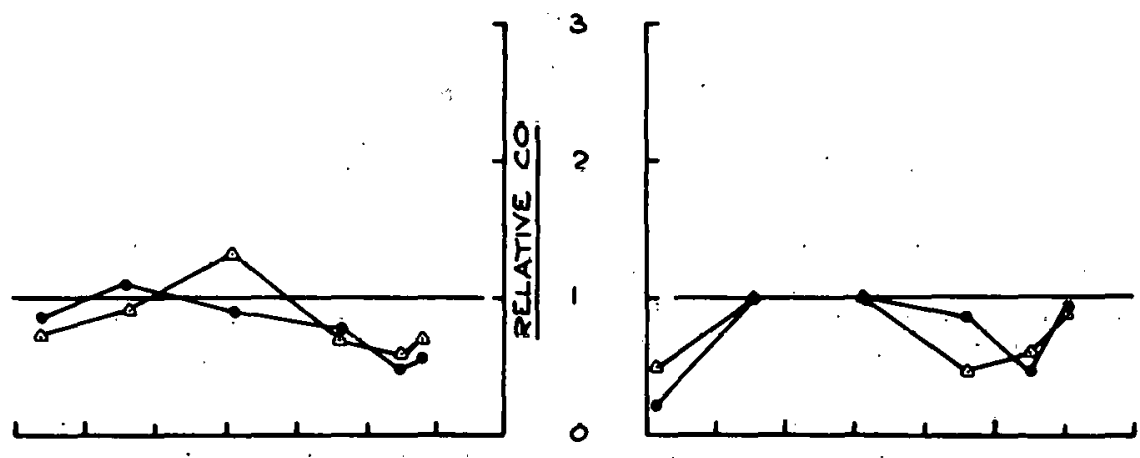

VARIABLE IGNITION QUALITY FUELS

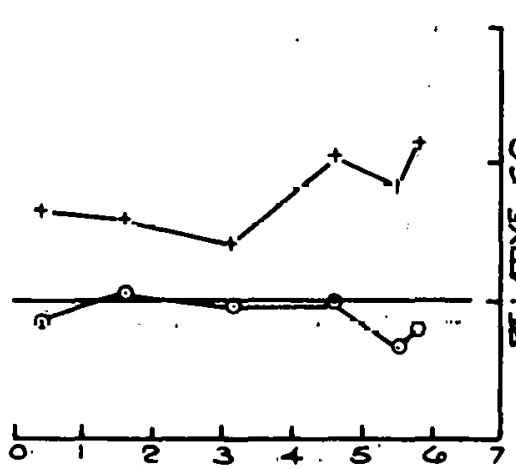

3

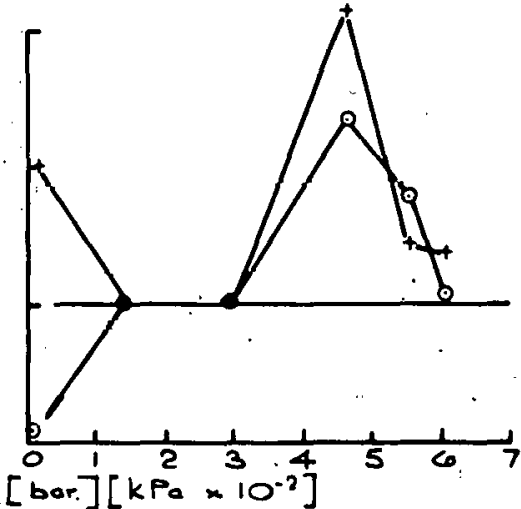

BM.E.P. [bar. $\left[\mathrm{KPa} \times 10^{-2}\right]$ 
APPENDIX 4 g-2 INFLUENCE OF ALTERNATIVE

FUELS:- RELATIVE CO

EMISSIONS A' $40 \mathrm{rev} / \mathrm{s}$

(2400 rev/min)

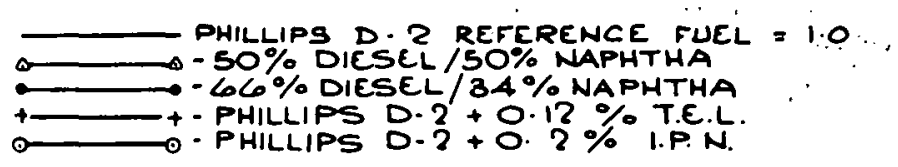

IDI DIESEL

DI. DIESEL.

VARIABLE VOLATILITY FUELS
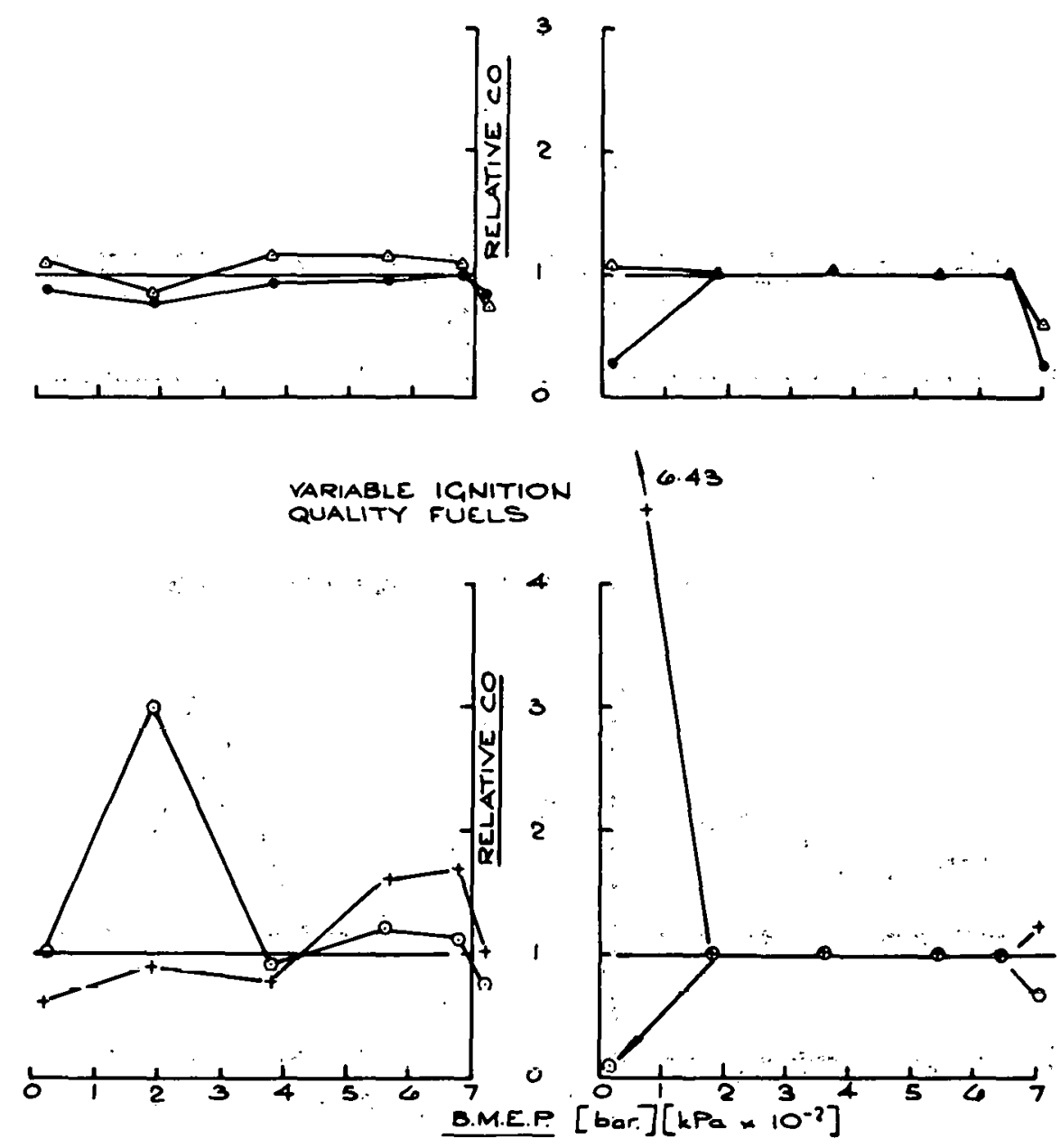
APPENDIX $4 \mathrm{~g}-3$ INFLUENCE OF ALTERNATIVE

FUELS : - RELATIVE CO

EMISSIONS AT $60 \mathrm{rev} / \mathrm{s}$

(3600 $\mathrm{rev} / \mathrm{min}$ )

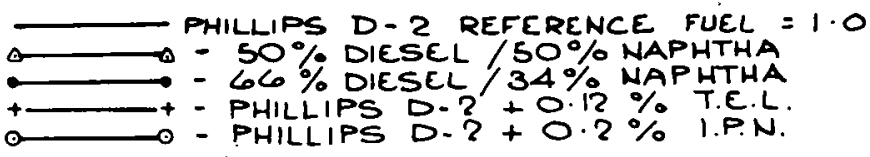

VARIABLE VOLATILITY FUELS
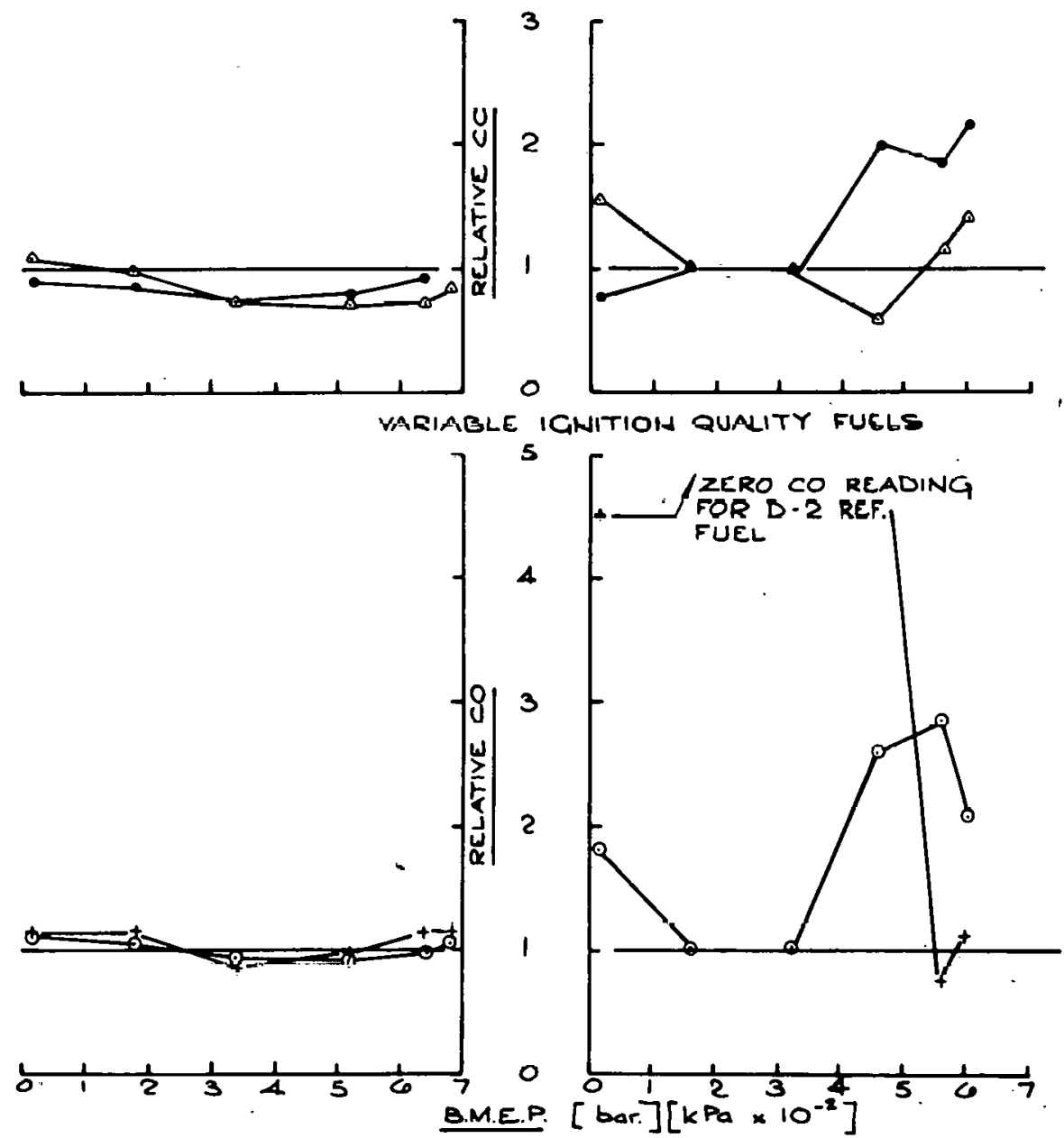


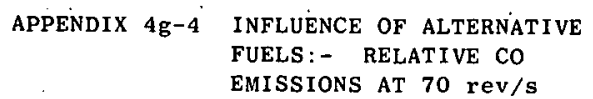

(4200 rev/min)

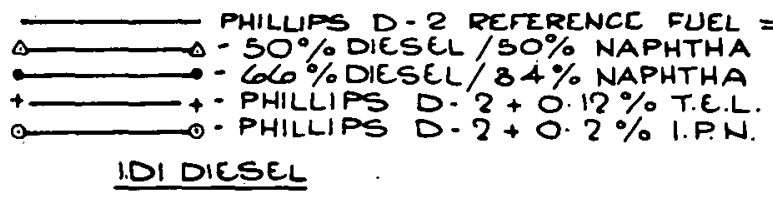

DI DIESEL
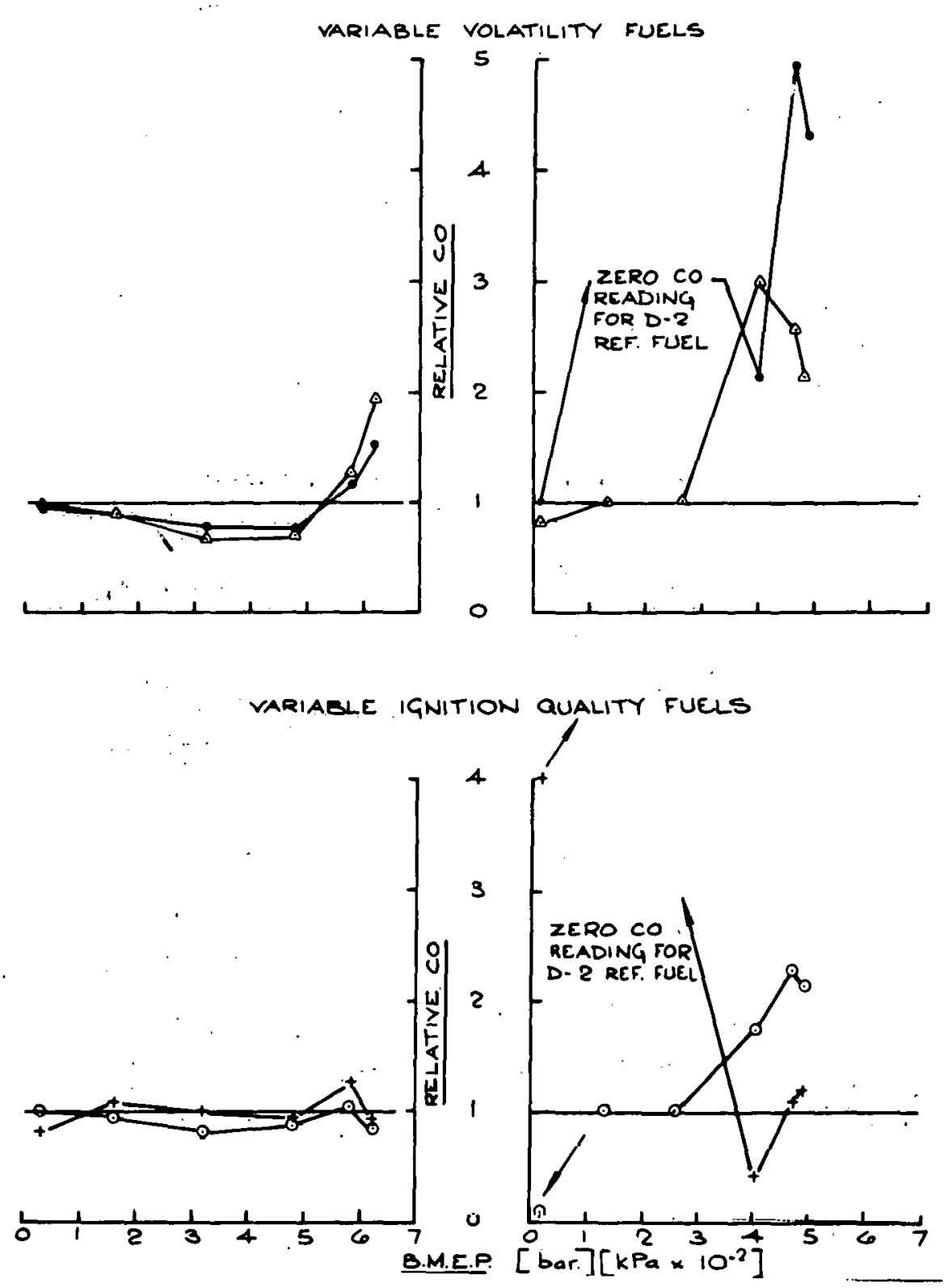
APPENDIX $4 \mathrm{~h}-1$ INFLUENCE OF ALTERNATIVE

FUELS : - COMPARISON OF

EXHAUST SMOKE AT $20 \mathrm{rev} / \mathrm{s}$

(1.200 $\mathrm{rev} / \mathrm{min})$

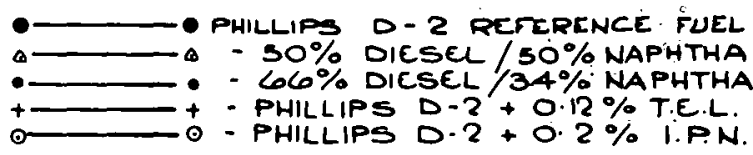

IDIDIESEL

DI DIESEL

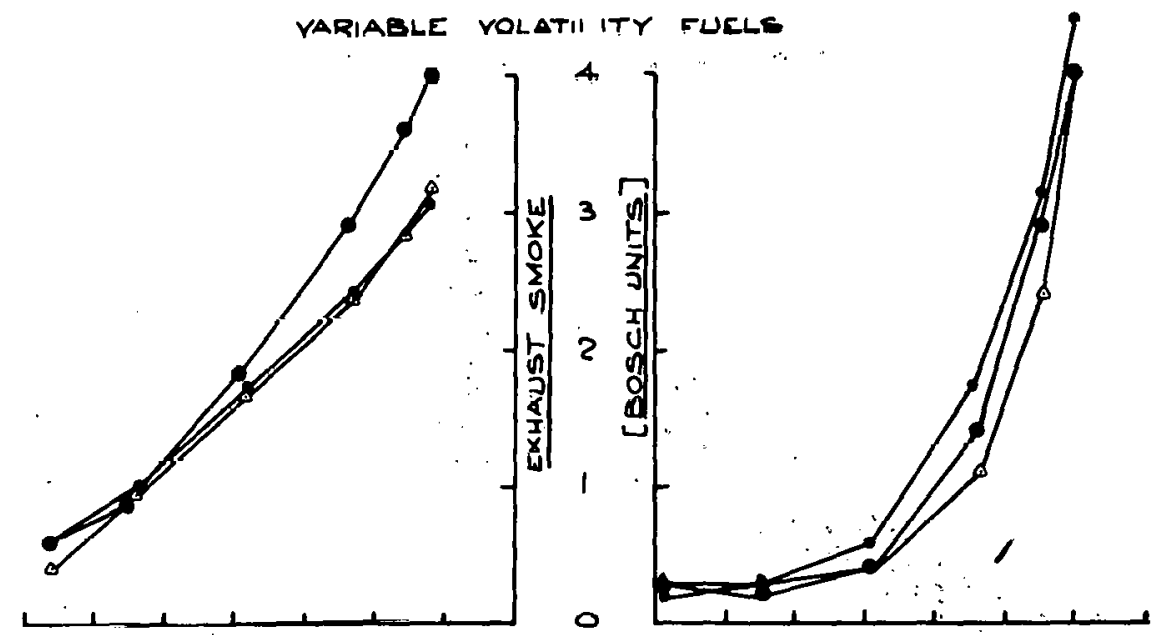

VARIAELE IGNITION QUALIT'T FUELS

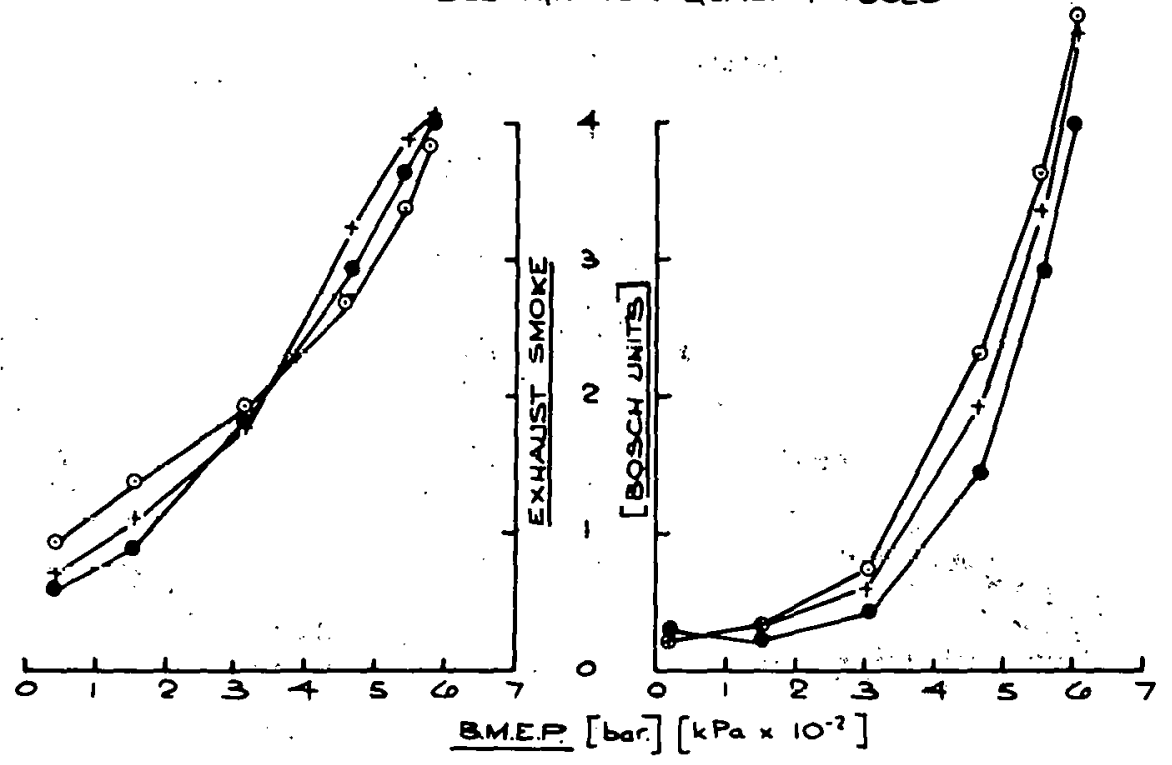


APPENDIX 4h-2 INFLUENCE OF ALTERNATIVE

FUELS : - COMPARI SON OF

EXHAUST SMOKE AT $40 \mathrm{rev} / \mathrm{s}$

$(2400 \mathrm{rev} / \mathrm{m} 1 \mathrm{n})$

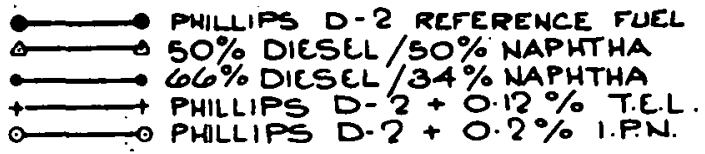

IDI DIESEL

VARIABLE YOLATILITY FUELS
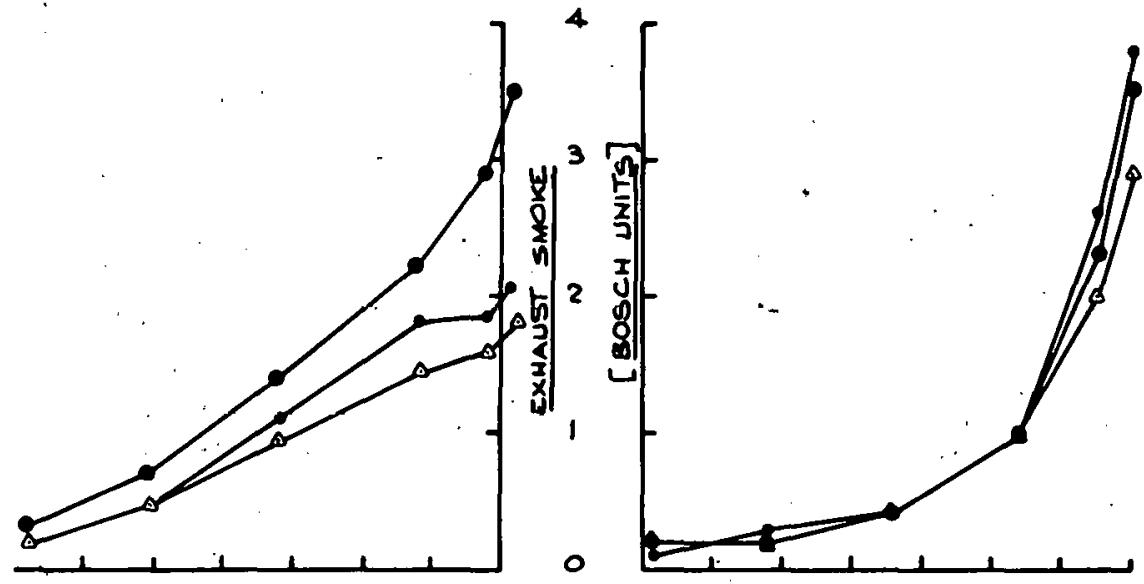

VARIABLE IGNITION QUALITY FUELS

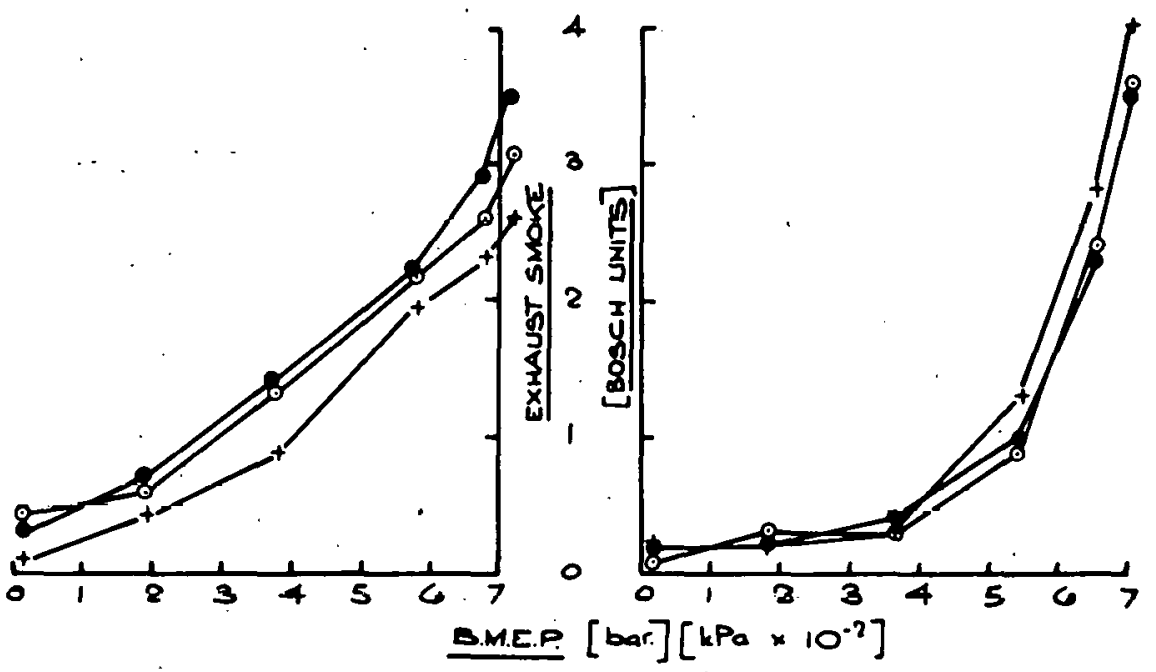


APPENDIX 4h-3 INFLUENCE OF ALTERNATIVE

FUELS : - COMPARISON OF

EXHAUST SMOKE AT $60 \mathrm{rev} / \mathrm{s}$

(3600 rev/min)

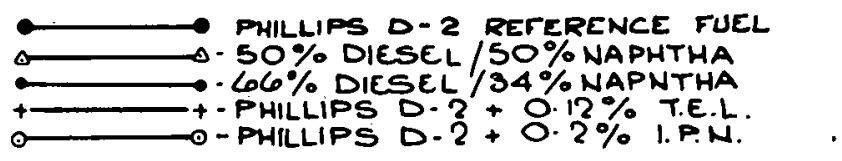

101 DIESEL

DI DIESEL

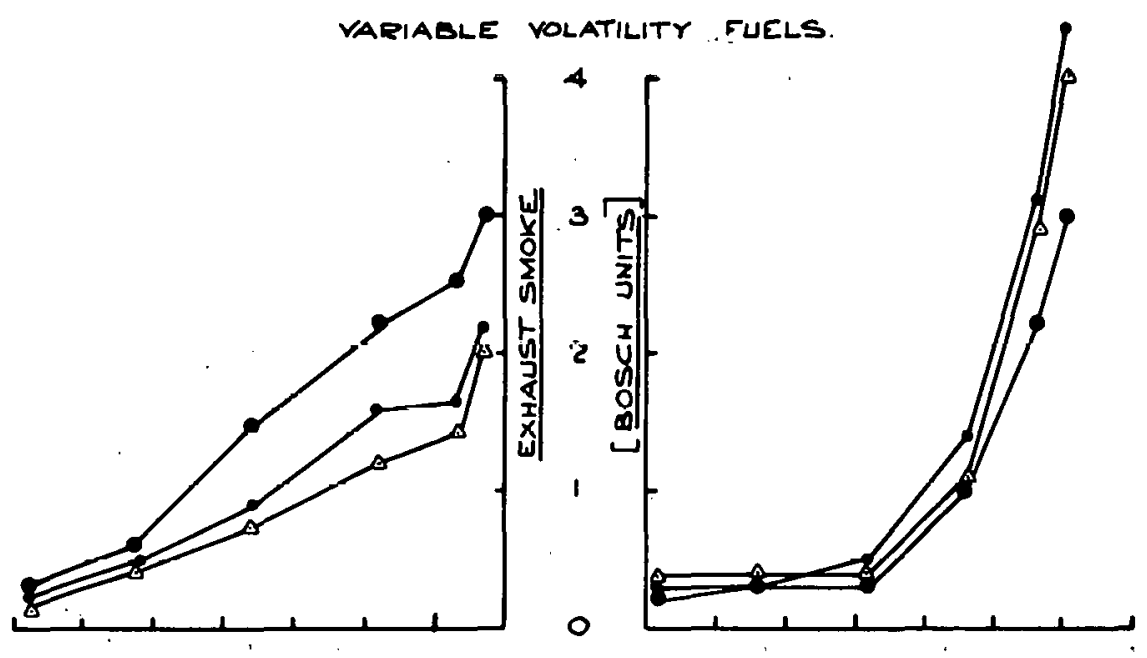

VARIABLE IGNITION QUALITY FUELS

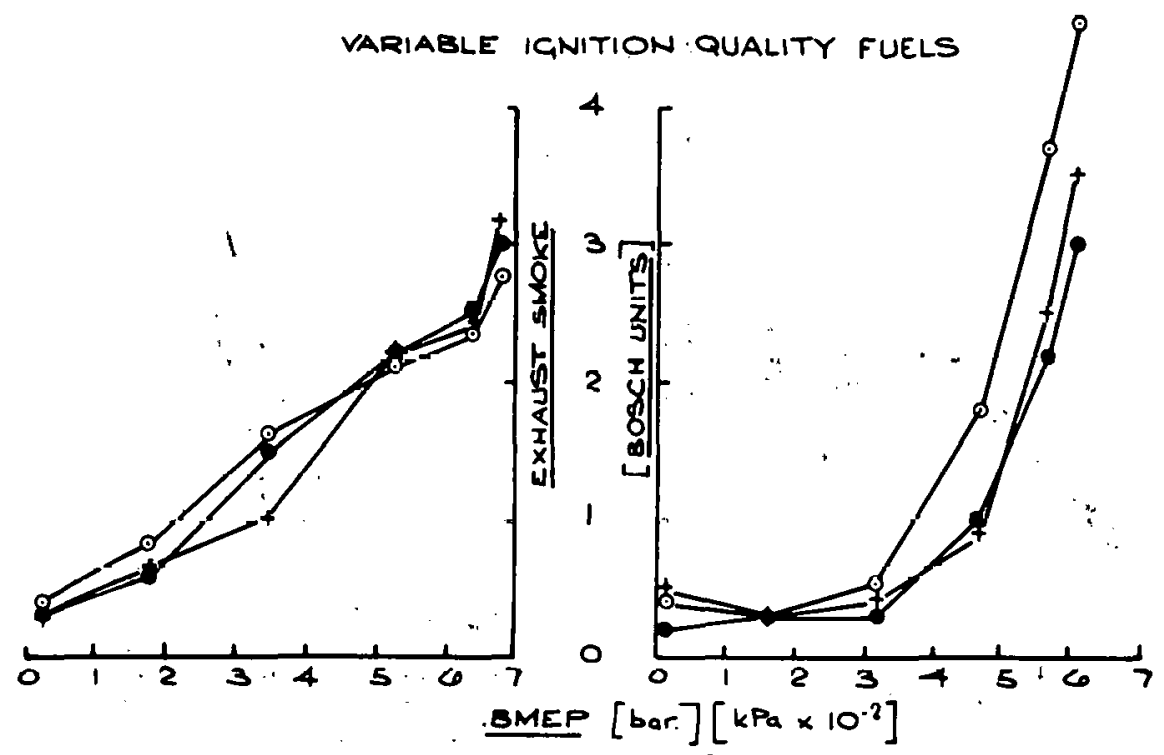


APPENDIX 4h-4 INFLUENCE OF ALTERNATIVE FUELS :- COMPARISON OF

EXHAUST SMOKE AT $70 \mathrm{rev} / \mathrm{s}$

(4200 rev/min)

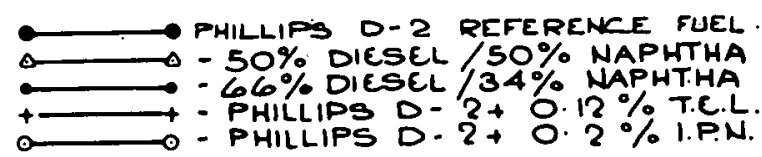

IDI DIESEL

\section{DIESEL}

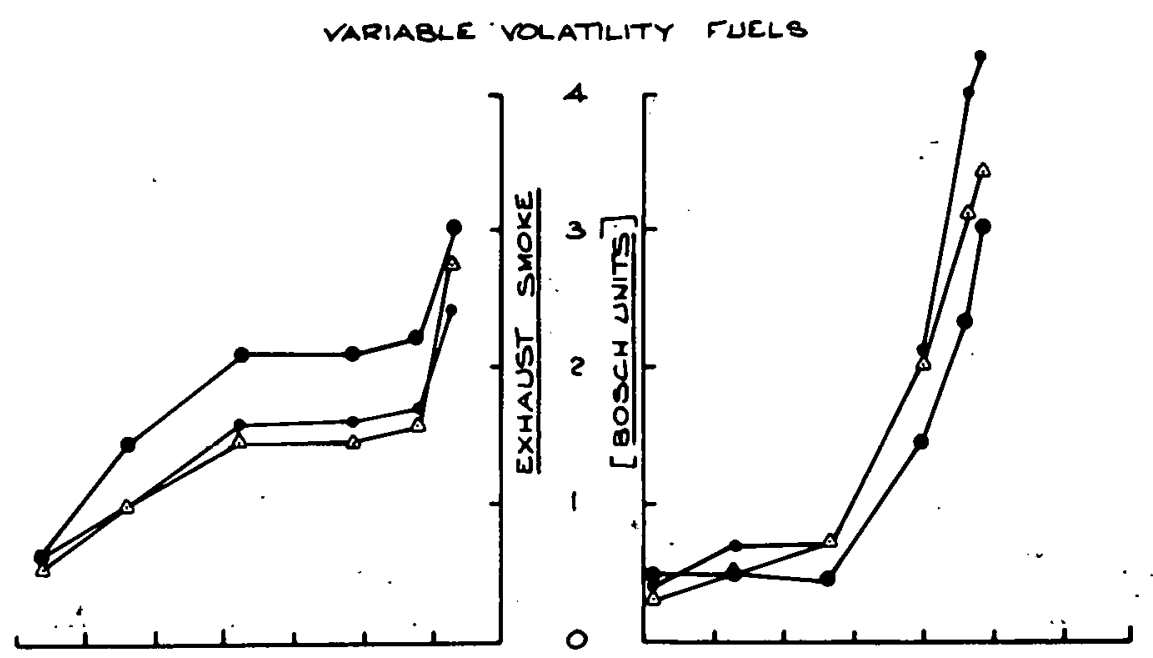

- variable ignition quality

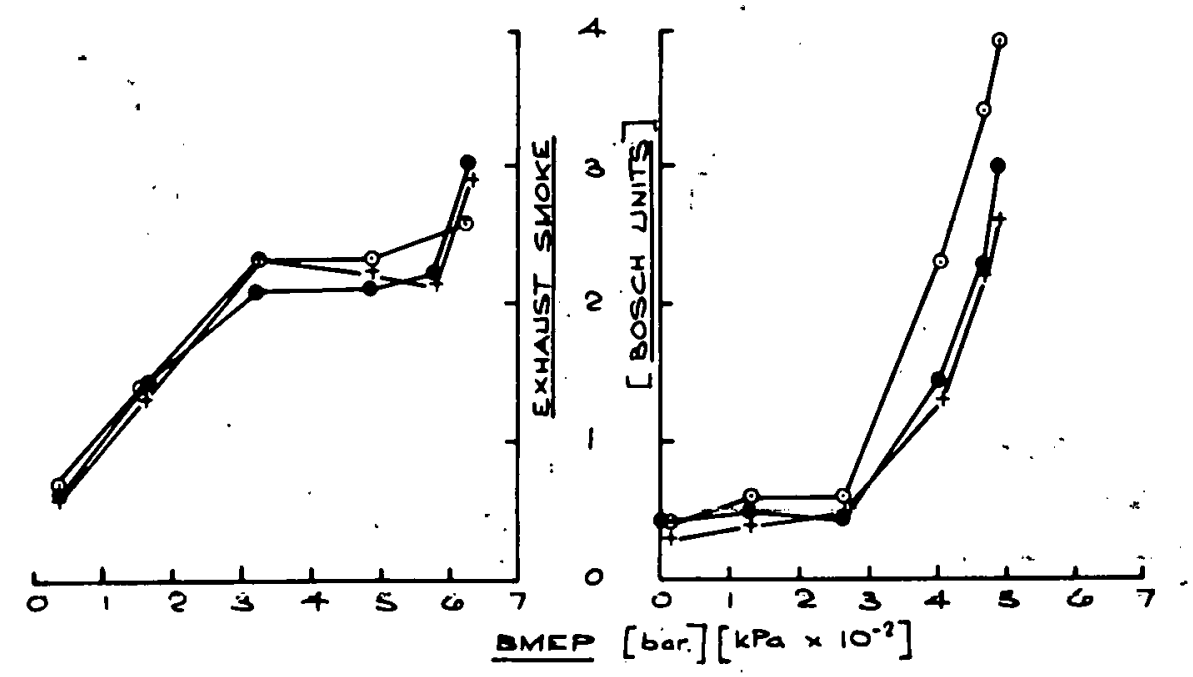


$+\longrightarrow+-2$

$\odot--\infty$ STRAIGHT RUN NAPHTHA (SRN)

$\star----\star 73 / 27 \%$ D-2/SRN

$\Delta \longrightarrow \longrightarrow 36 / 66 \%$ D-2/SRN

$\square--\square 50 / 50 \%$ LIGHT CYCLE OIL /GAS OIL

$\nabla--\nabla$ 40/60\% LIGHT CYCLE OIL /GAS OIL
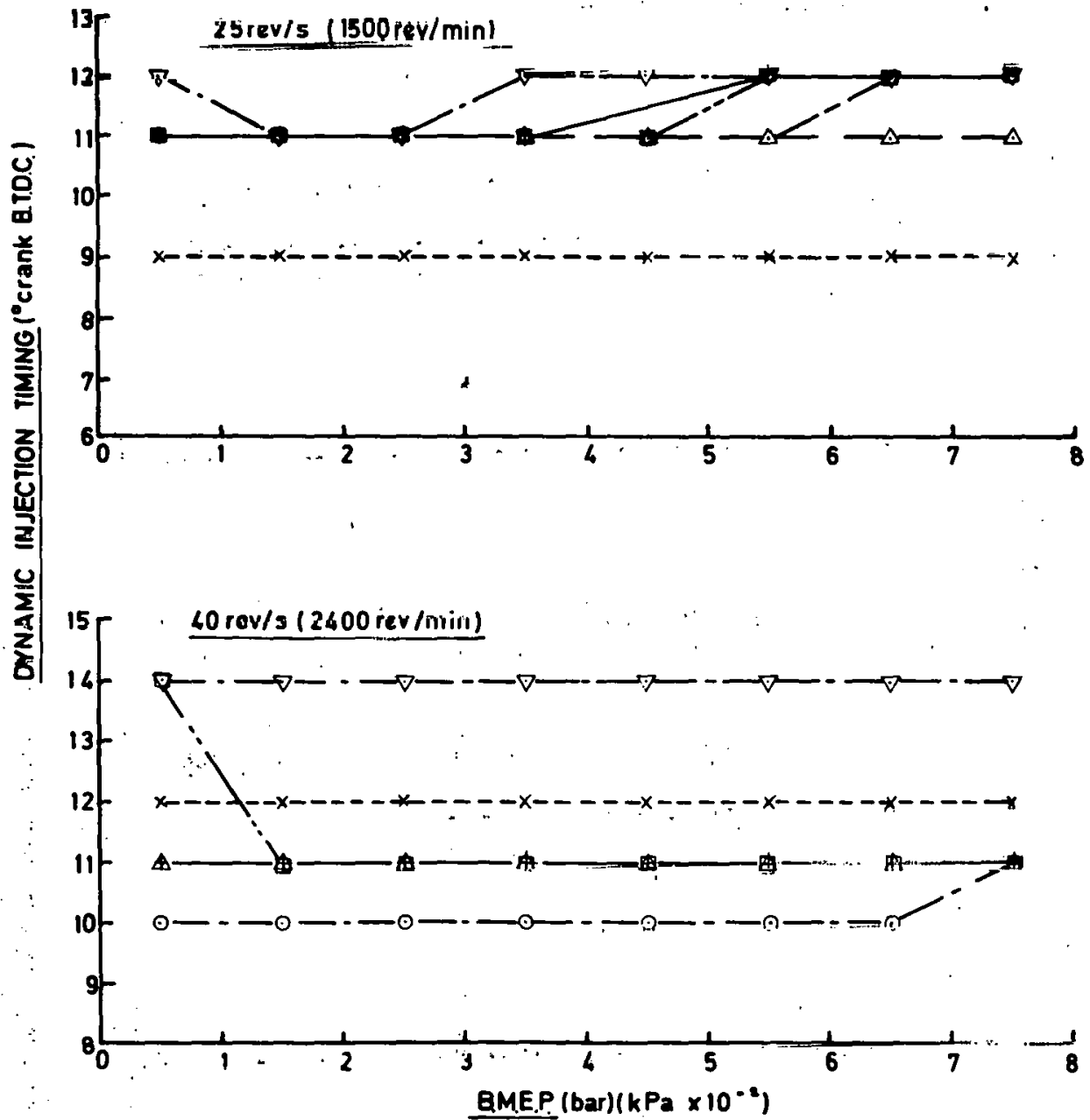
APPÉNDIX $5 \mathrm{~b}$ TIMING PLAN FOR DI DIESEL

SELECTED FOR MINIMUM FUEL CONSUMPTION

$+\longrightarrow+0-2$

$x-\cdots--73 \% / 27 \%$ D.2 /SRN

$\square-\square 50 \% / 50 \%$ LIGHT CYCLE OIL/GAS OIL

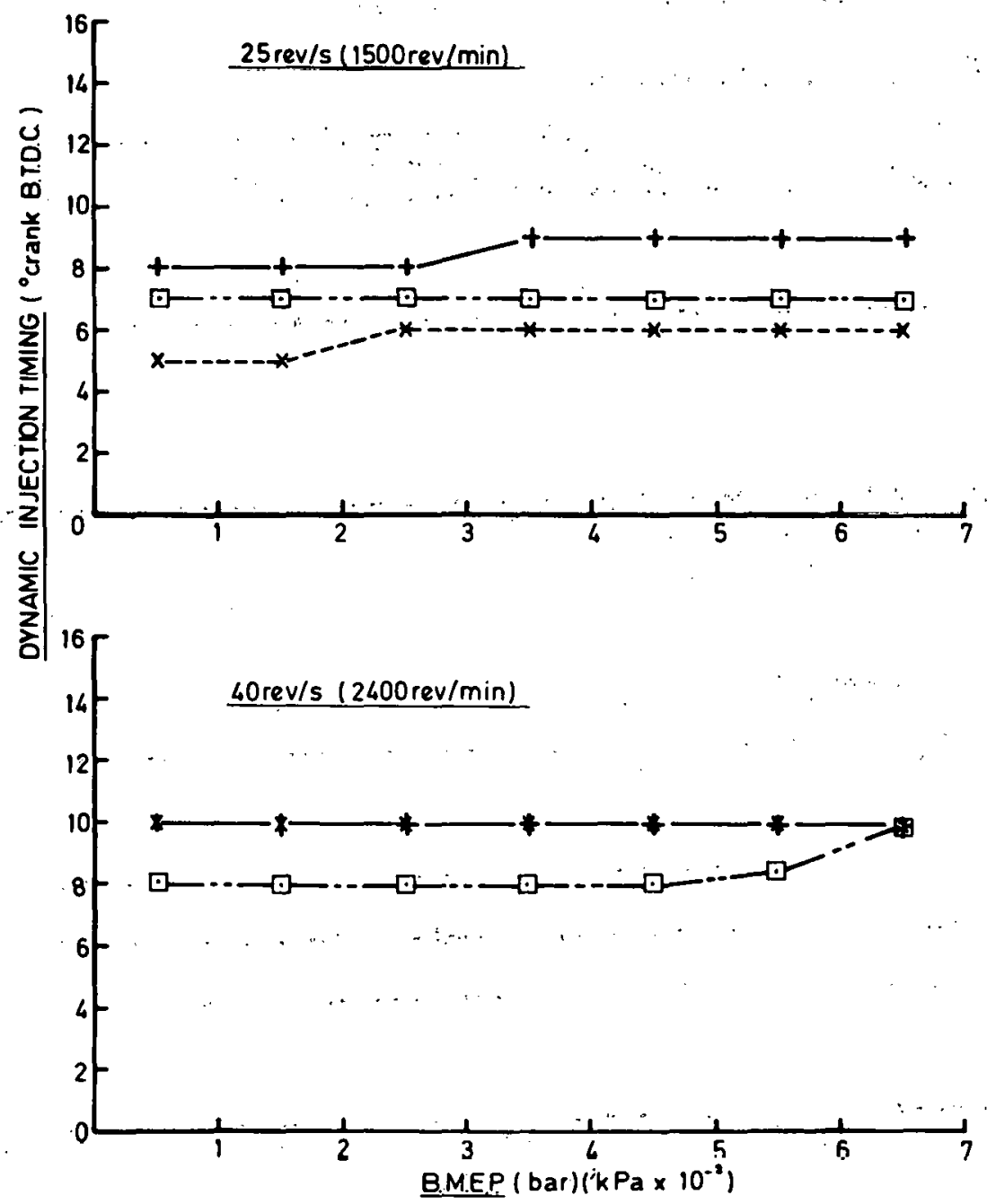



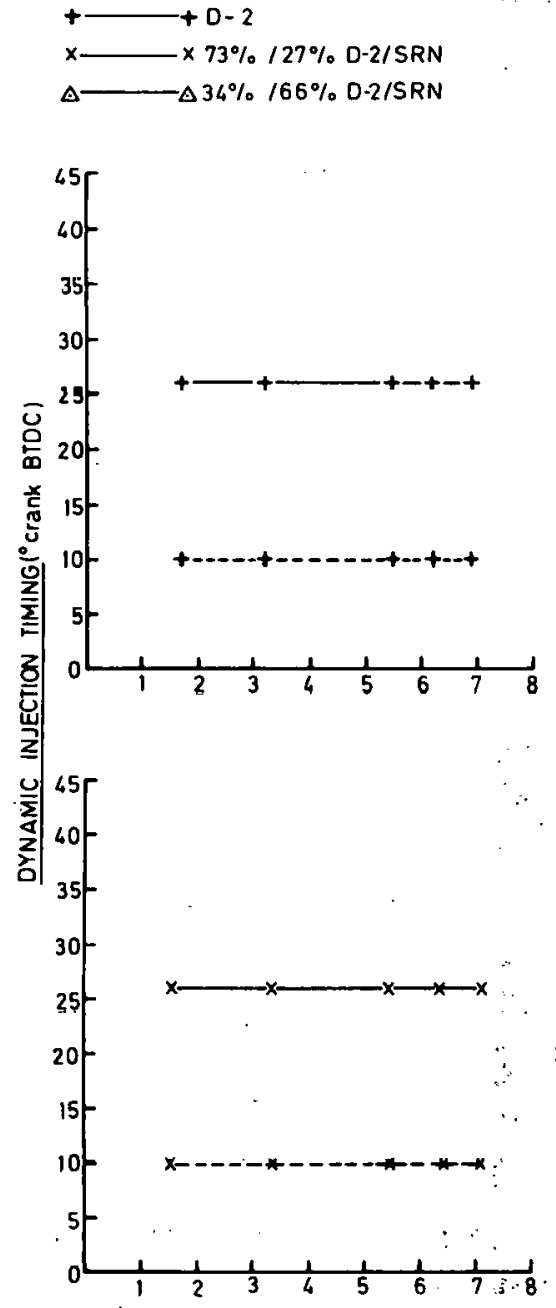

BMEP (bar) (kPa $\left.\times 10^{-i}\right)$
INJECTION TIMING

----- IGNTION TIMING

$25 \mathrm{rev} / \mathrm{s}$ (1500 rev/min)

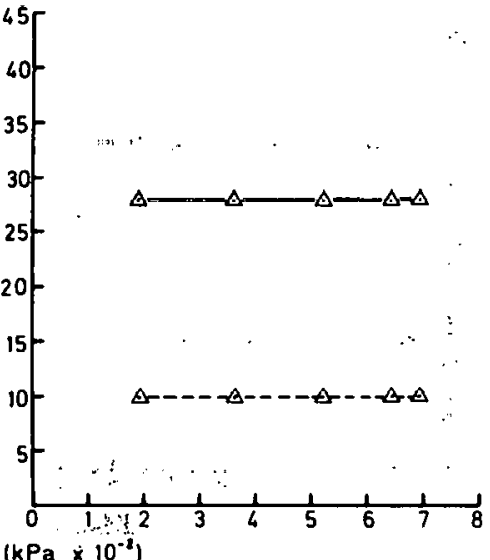


SELECTED FOR MINIMUM

FUEL CONSUMPTION

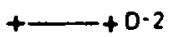

$\longleftrightarrow \times 73 \% / 27 \% 0-2 /$ SRN

INJECTION TIMING

$\triangle-\triangle 34 \% / 66 \%$ D.2/SRN
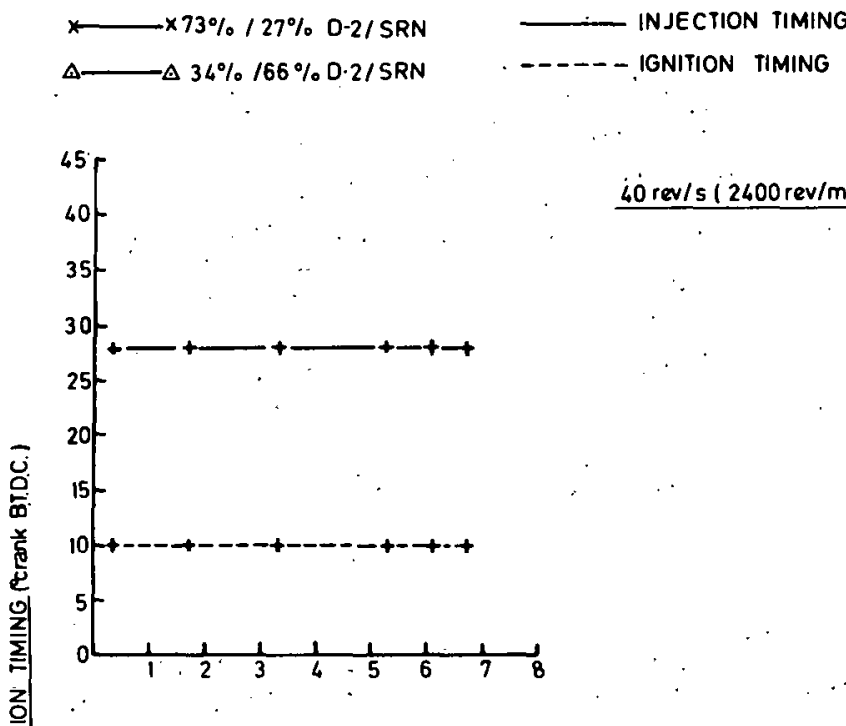

$40 \mathrm{rev} / \mathrm{s}(2400 \mathrm{rev} / \mathrm{min})$

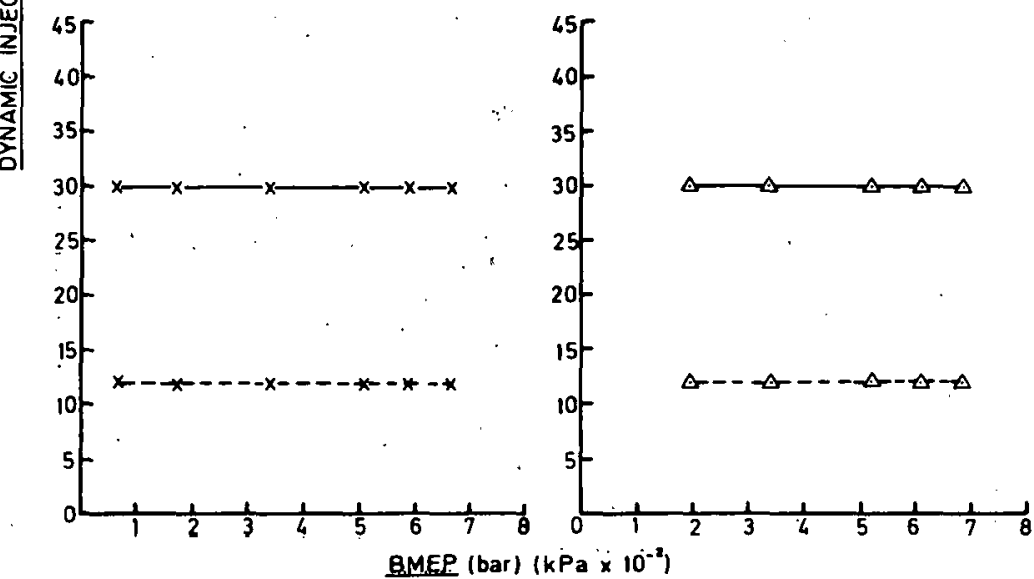


$+-+0-2$

$\odot-\odot$ STRAIGHT RUN NAPHTHA

*-.-- $73 \% / 27 \% \quad 0-2 /$ SRN

$\triangle \longrightarrow 34 \% / 66 \%$ D-2/SRN

๑- 50\%/50\% LIGHT CYCLE OIL/GAS OIL
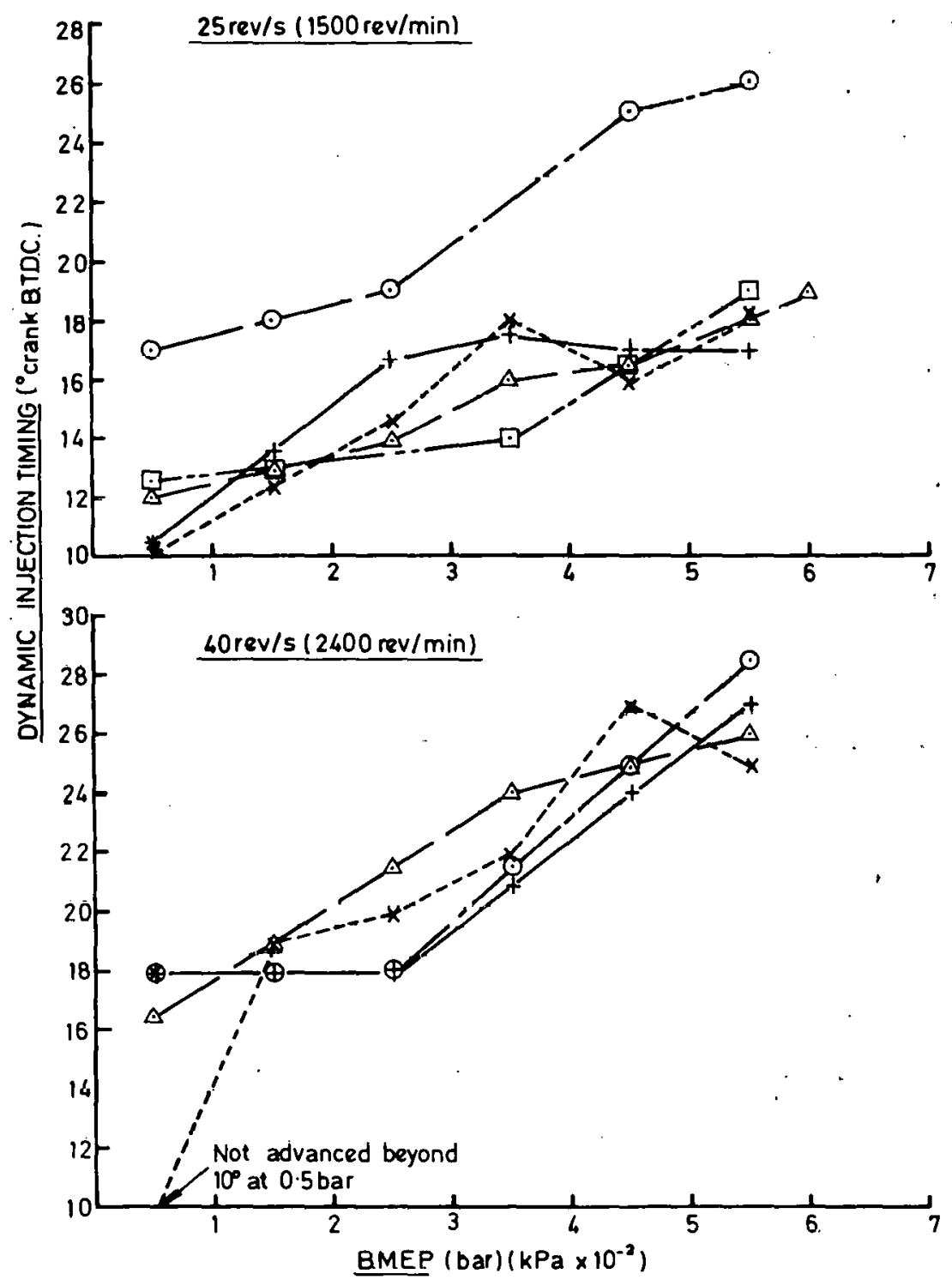


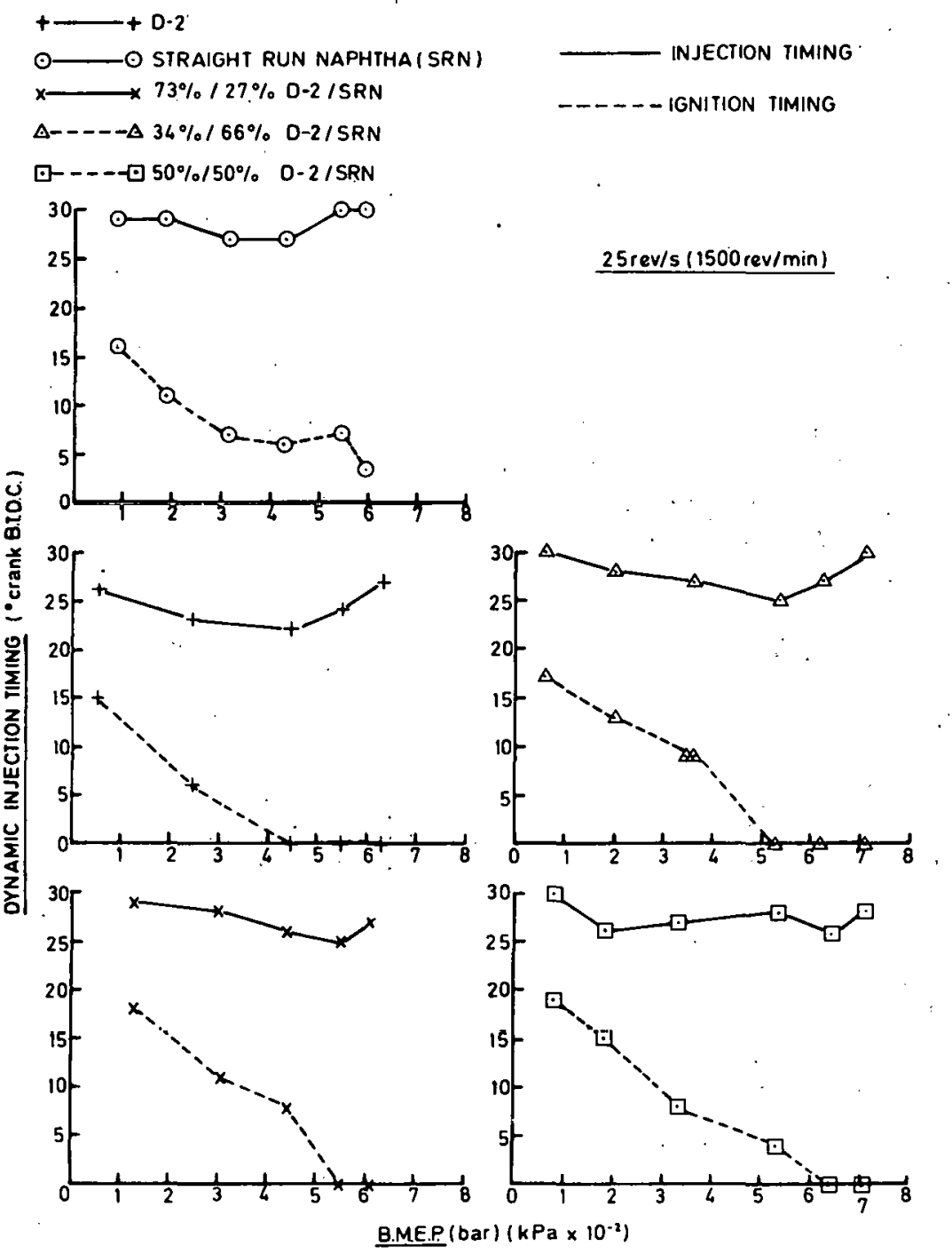




\section{APPENDIX 5g : TIMING PLAN FOR MAN FM SELECTED FOR MINIMUM \\ FUEL CONSUMPTION}

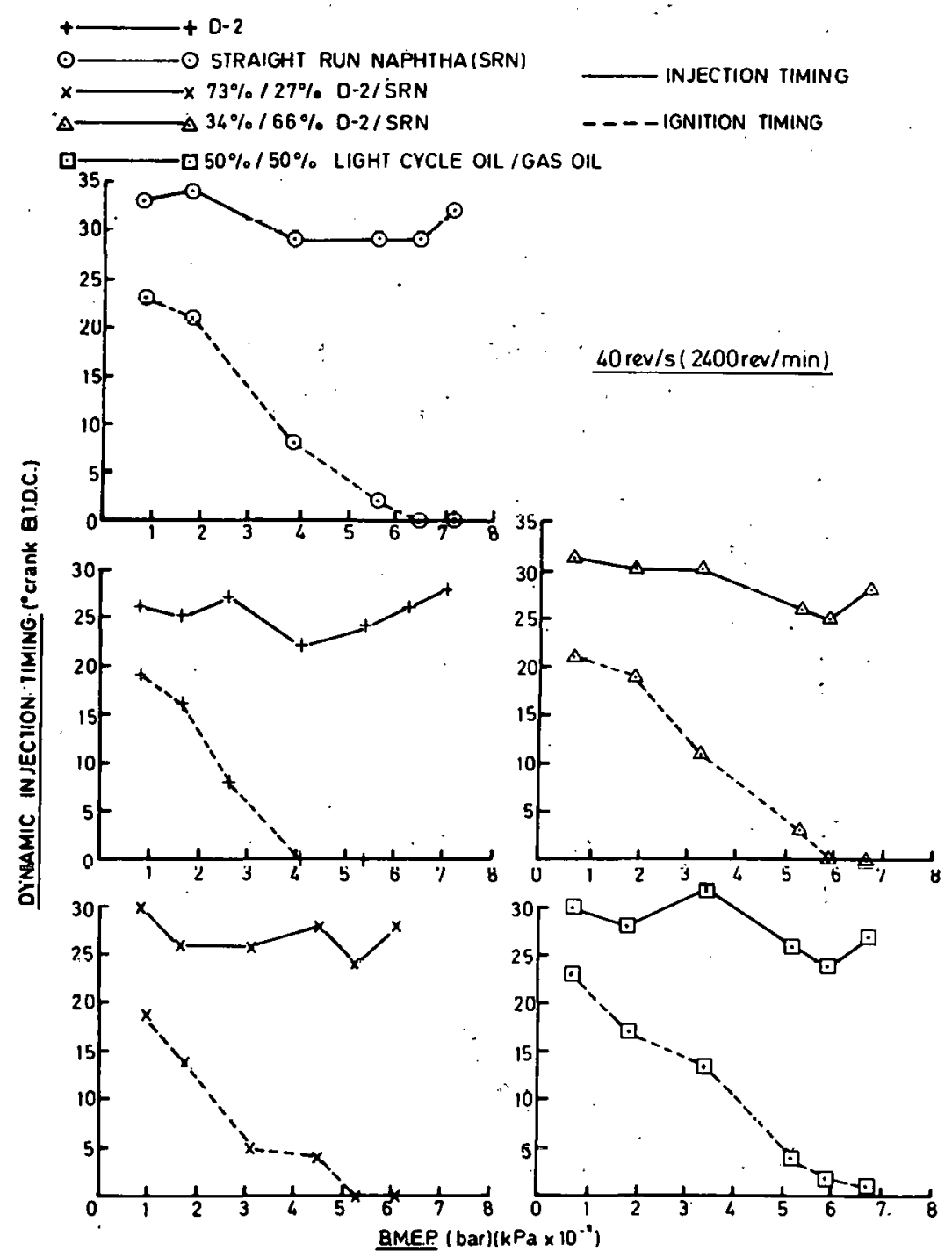



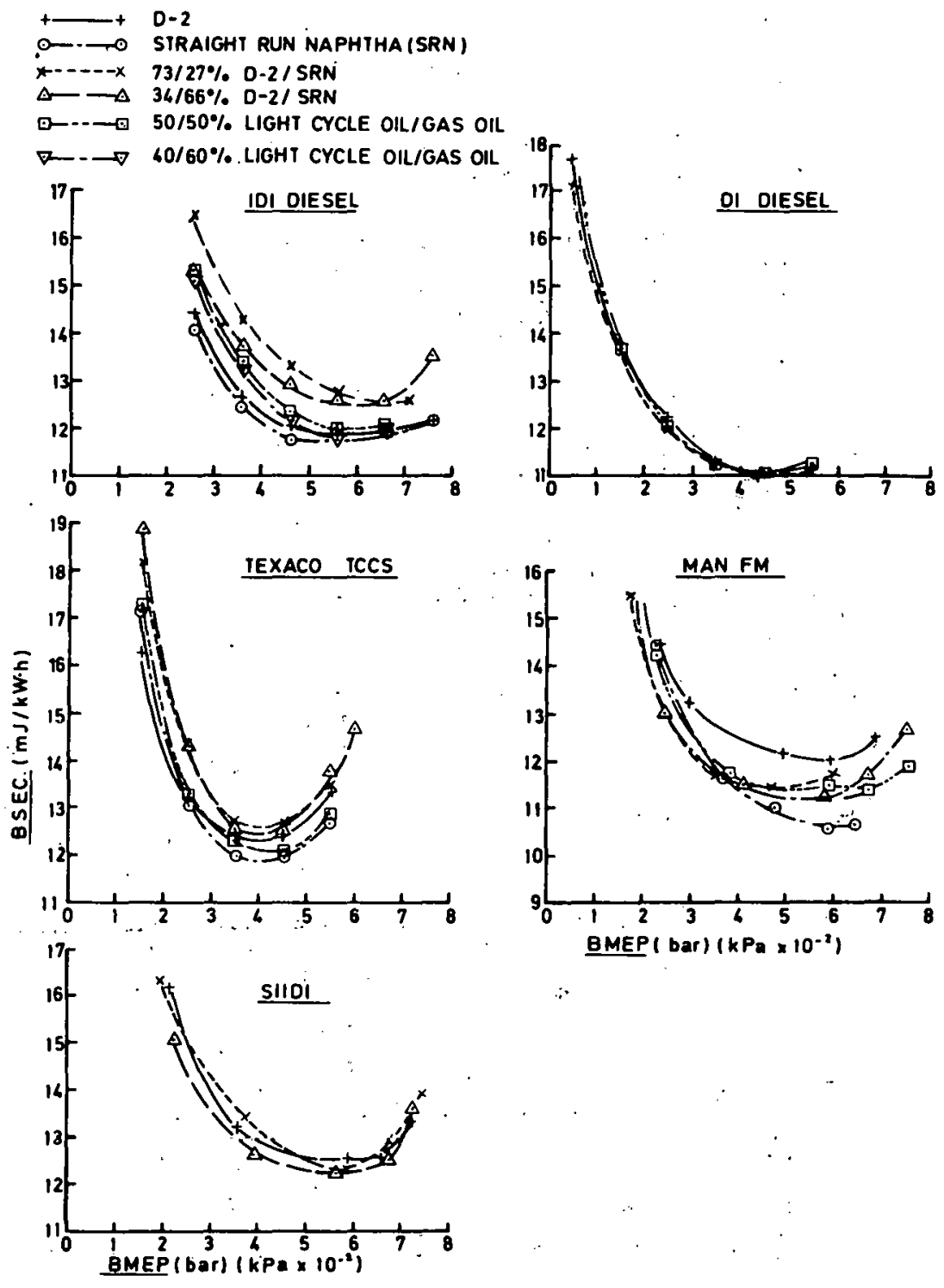


\section{APPENDIX 6b BRAKE SPECIFIC ENERGY \\ CONSUMPTION AT $10 \mathrm{rcv} / 3$ \\ (2400 rev/min) ALL \\ FUELS AND SYSTEMS.}

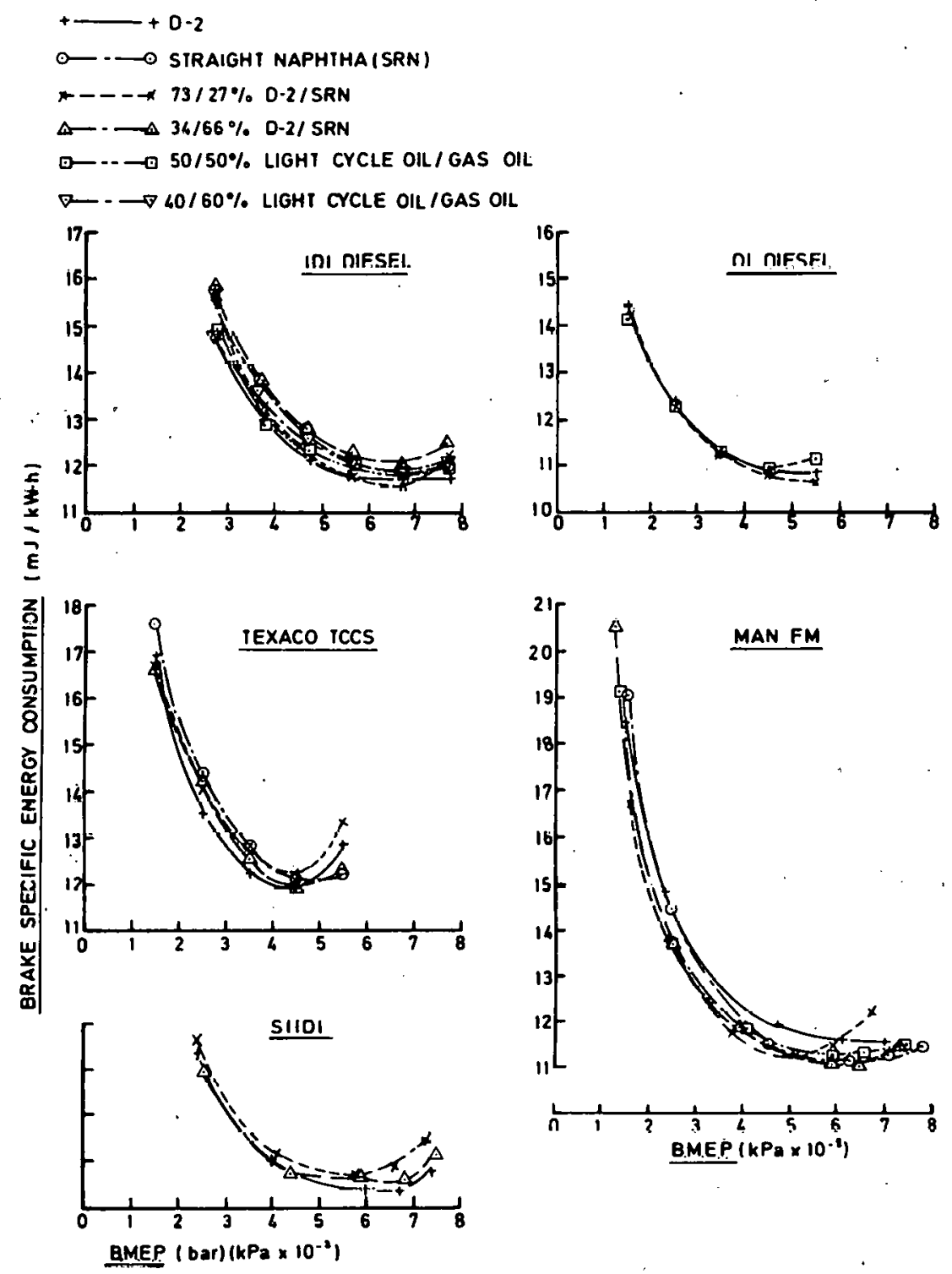


APPENDIX $7 \mathrm{a}$ EMISSIONS TRADE-OFF

IDI DIESEL $25 \mathrm{rev} / \mathrm{s}$

(1500 rev/min)
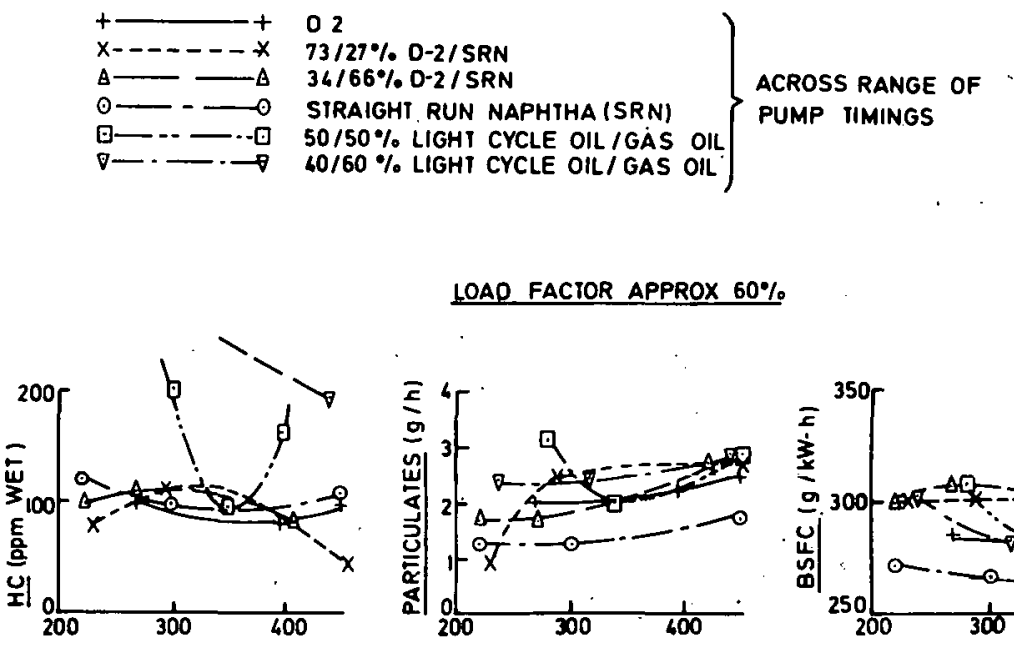

LOAP FACTOR APPROX $60 \%$
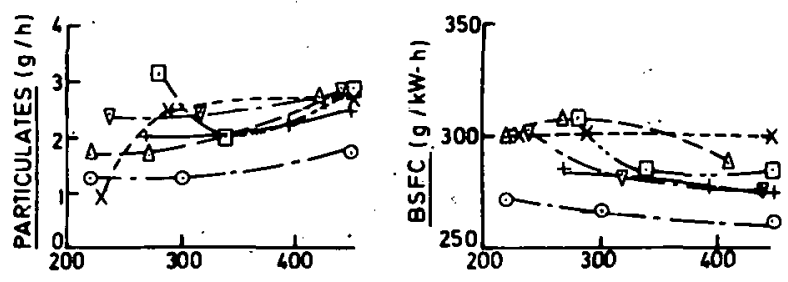

NOX (PPM WET)

LOAO FACIOR APPROX $25 \%$
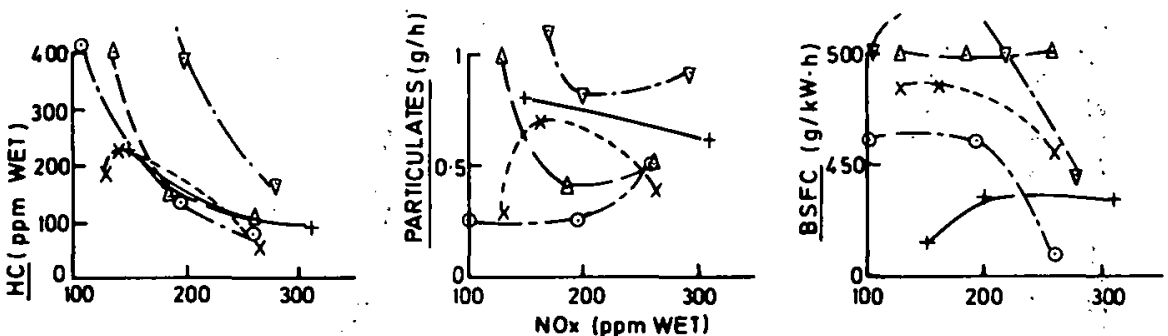


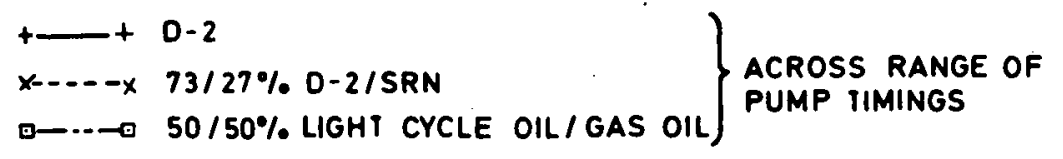

LOAO FAC:INR APPROX 60\%
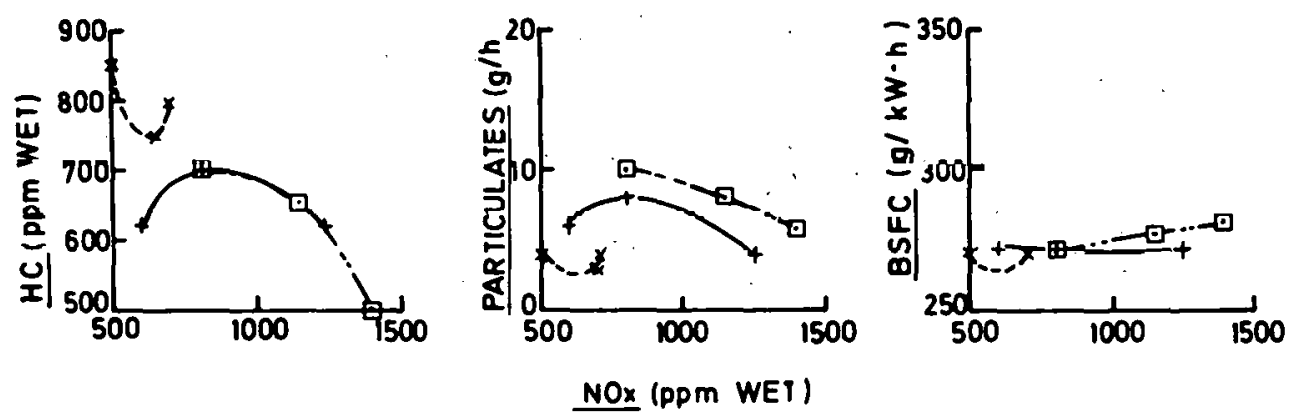

NOX (PPM WET)

\section{. LOAO FACIOR APPROX $25 \%$}

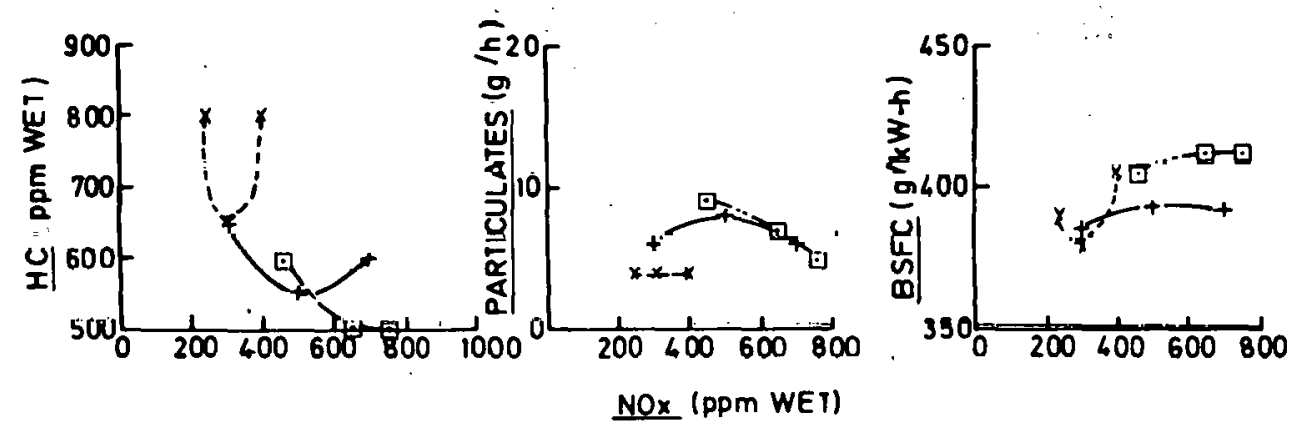




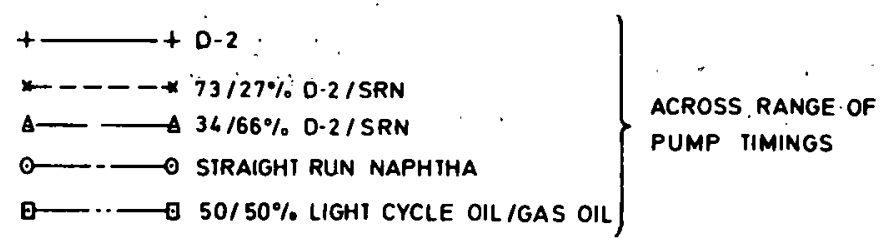

LOAD FACTOR APPROX $00 \%$
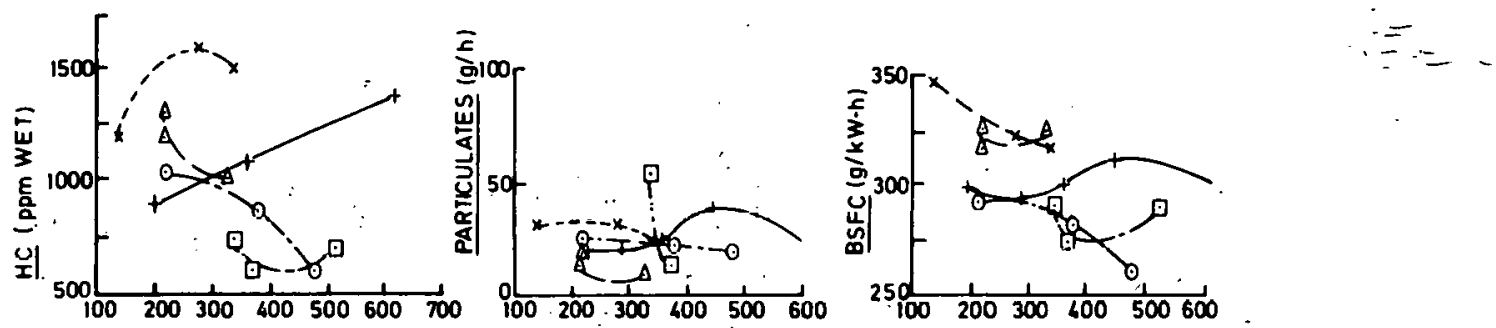

NOX (ppm WET)

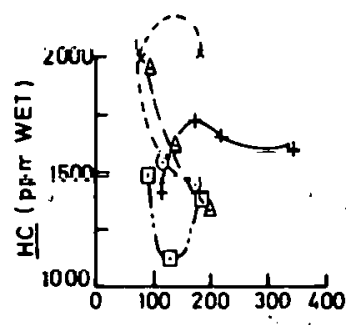

LOAO FACTOR APPROX $25 \%$
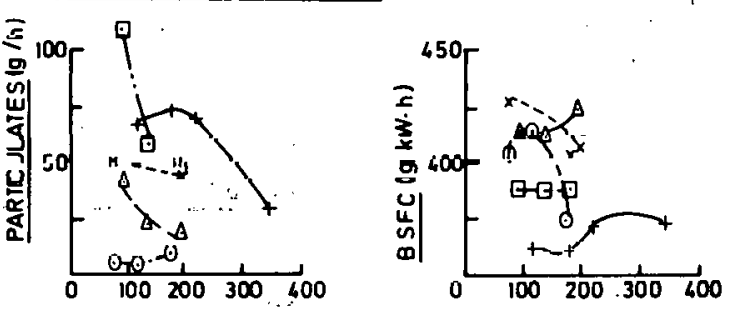

NOX (pPm WE $T$ ) 

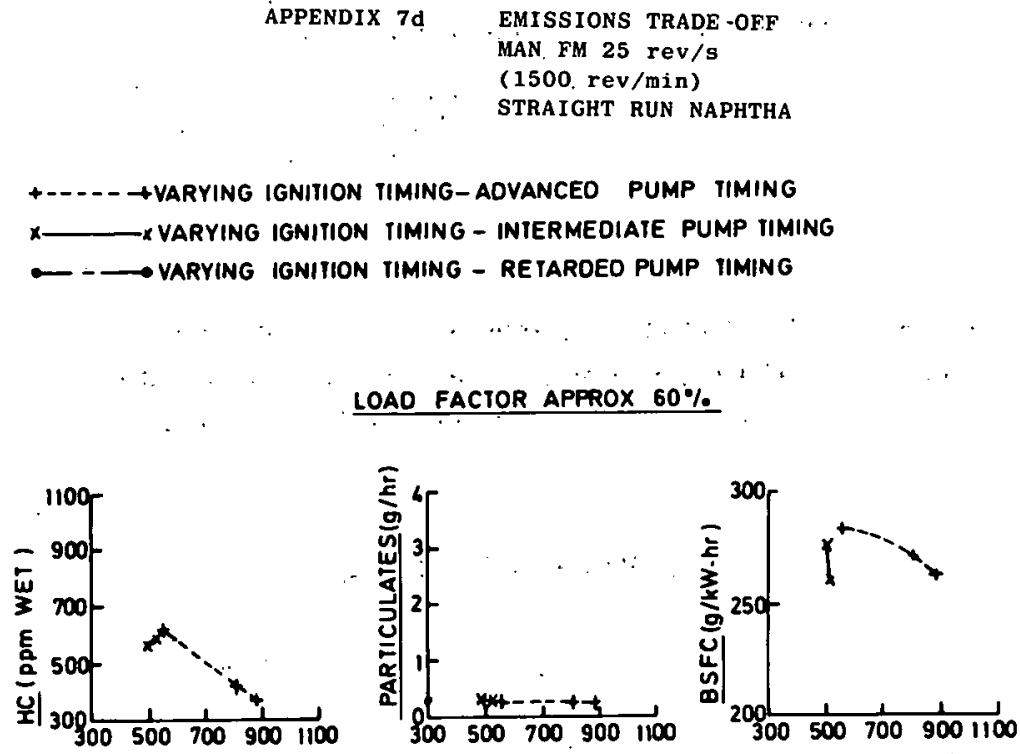

NOX (ppm WET)

\section{$25 \%$ LOAD FACTOR DATA NOT AVAILABLE}

APPENDIX 7e . EMISSIONS TRADE -OFF

MAN FM 25 rev/s

(1500 rev/min)

50/50\% LIGHT CYCLE OIL/

GAS OIL
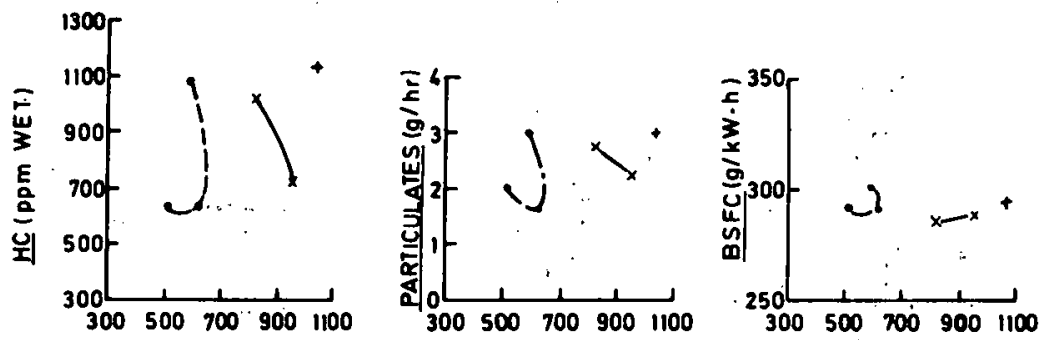

NOX (ppm WET)

LOAO FACTOR APPROX $25 \%$
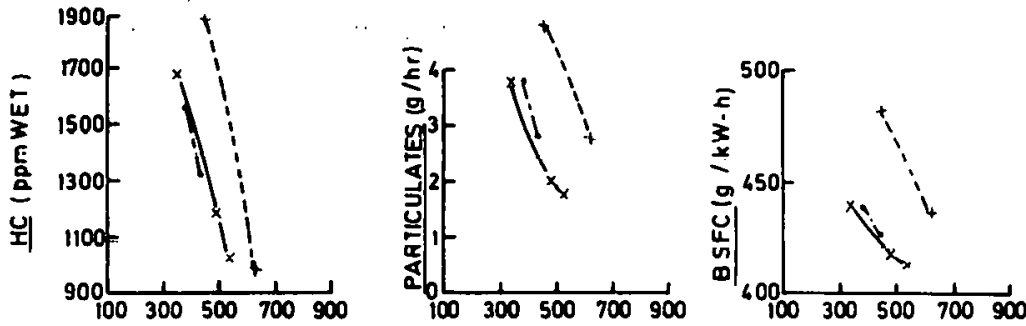

NOX (ppm WE T) 


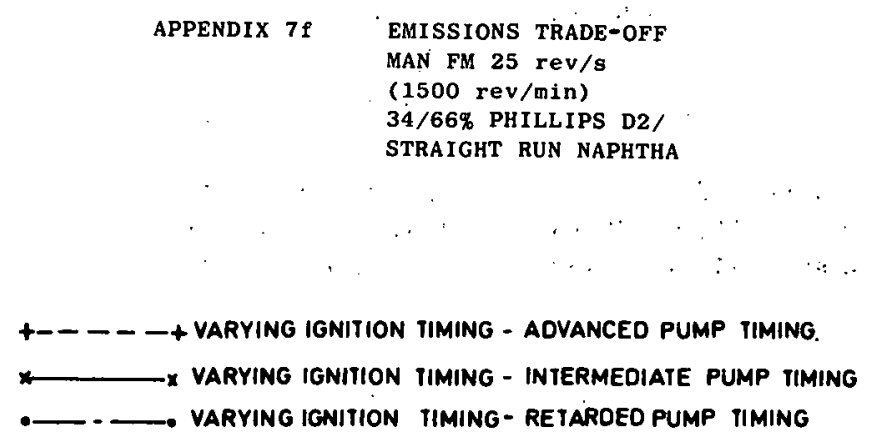

\section{LOAD FACTOR APPROX $60 \%$}
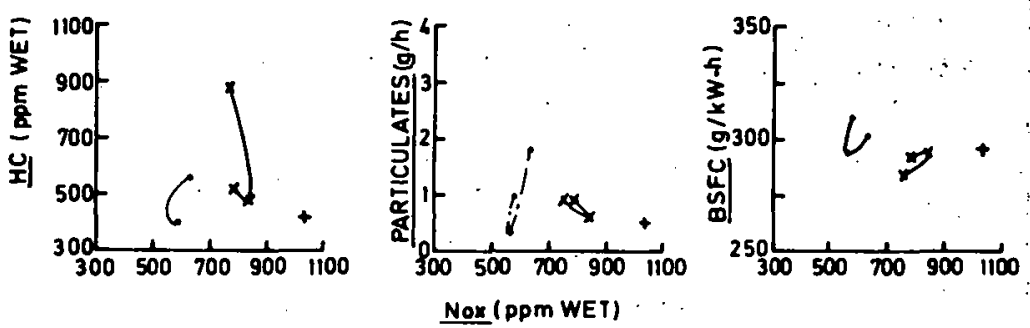

LOAD FACTOR APPROX $25 \%$
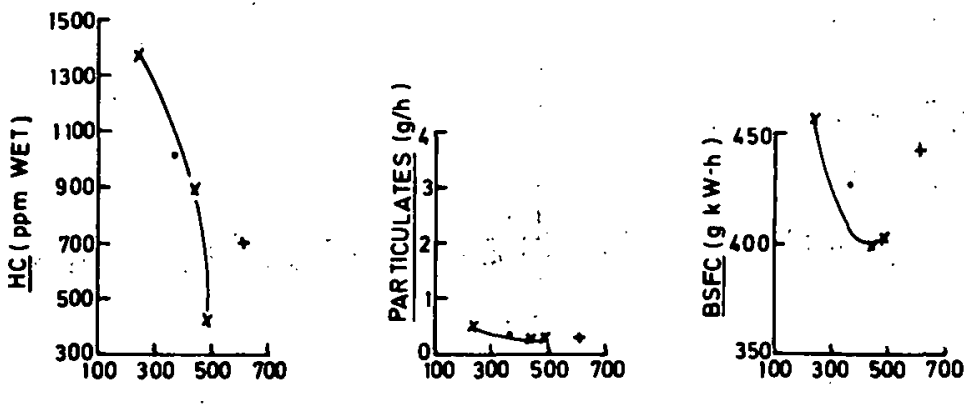

NOX (ppm WET) 